\title{
АЛЕКСАНДР АПУХТИН
}
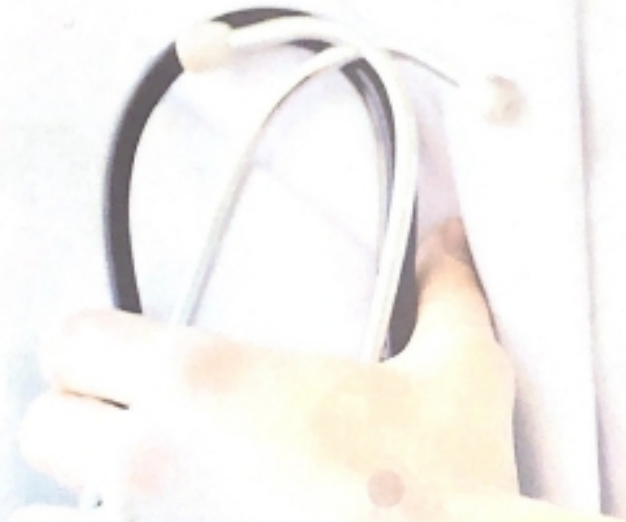

D

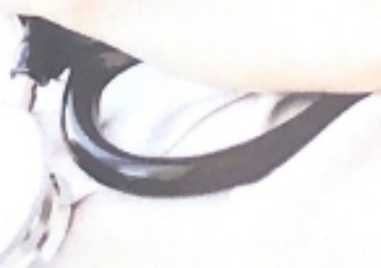

\section{МЕДИКО-СОЦИАЛЬНЫЕ АСПЕКТЫ НОВАЦИЙ И ИЗОБРЕТЕНИЙ}

(НА ПРИМЕРЕ РЕГИОНА РОССИИ) 
АПУХТИН АЛЕКСАНДР ФЕДОРОВИЧ

\section{МЕДИКО-СОЦИАЛЬНЫЕ АСПЕКТЫ НОВАЦИЙ \\ И ИЗОБРЕТАТЕЛЬСТВА \\ (на примере региона России)}

Санкт-Петербург

СУПЕР Издательство

2020 год 
УДК 61-61(035.3)

ББК 74.40я723

A78

Книга издается в авторской редакции

A78

Апухтин Александр

Медико-социальные аспекты новаций и изобретательства (на примере региона России) / Апухтин Александр Федорович. Санкт-Петербург, СУПЕР Издательство, 2020. - 282 с.

https://www.super-izdatelstvo.ru/

Все права защищены. Никакая часть данной книги не может быть воспроизведена в какой бы то ни было форме без письменного разрешения правообладателя.

ISBN 978-5-9965-0522-7

(C) Александр Федорович Апухтин, 2020

(c) СУПЕР Издательство, 2020 


\section{Предисловие автора}

Выбор образа жизни, вида деятельности, книг, покупок и поступков в руках самого индивидуума. Миллионы и миллиарды людей ежедневно осуществляют свой индивидуальный выбор соединяя свои слова и действия в то, что называется жизнью. Автор сделал выбор публикацией материалов, значимость и спорность которых будут определять люди и время. Мотивированность выбора, по мнению автора, обусловлена необходимостью прохождения «полного изобретательского цикла» для достижения рубежности и принятия решения необходимости повторного цикла в любой сфере человеческой деятельности.

По мнению одного из авторитетнейших экспертов базового курса Академии Модерн ТРИЗ, акт выбора часто включает полный изобретательский цикл (Мета-Алгоритм МТРИ3): 1) человек испытывает потребность в чём-либо. Это определяет мотивацию его действий; 2) человек придумывает (изобретает) цель, достижение которой удовлетворило бы потребность (в данном случае улучшение демографии и здоровья россиян); 3) он придумывает (в данном издании анализирует, делает выводы и вносит предложения) и буквально изобретает способы достижения цели и находит (изобретает) идеи и решения; 4) он сравнивает идеи и выбирает лучшие. Иногда решения нет. И тогда он повторяет цикл, изменяет способы и даже цель (Орлов М.А, 2017).

Идеология повторения цикла, изменения способа и поставленной цели, особенно когда эффективного решения нет, прослеживается в критике первичного звена здравоохранения главой государства президентом В.В. Путиным с членами правительства 20 августа 2019 года:” ...безусловно, нам нужно принять дополнительные меры по укреплению первичного звена здравоохранения. Напомню еще раз, мы дважды это делали из федерального центра в расчете на то, что это будет подхвачено на местах, в регионах, но этого не происходит. 
И в этой связи нам, безусловно, нужно посмотреть на всю организацию этой работы. Это очевидный факт, просто очевидные вещи. .... На это нужно обратить внимание”. Автор предпринял, на основе «изобретательских» компетенций, попытку обратить внимание «на всю организацию этой работы» через сложившиеся противоречия, анализировать «...очевидный факт и просто очевидные вещи».. Насколько авторская позиция правомерна судить читателю.

Отзывы и критику просьба отправлять на e-mail: aapuhtin@inbox.ru

09.04.2020г Апухтин Александр.

PS. Хотя анализируются события хронологического характера, автором представлена их связь с текущими событиями, Материал книги не воспринимается легко и прозрачно. Нужно учитывать, что вопросы интеллектуальной собственности, технического регулирования, государственных закупок и лекарственного обращения за пределами России отнесены к праву ЕЭК (Европейской Экономической Комиссии) . Вероятно, это требует переоценки всего правового поля рассматриваемых вопросов со ссылкой на документы ЕАЭС. Однако ЕАЭС, как свидетельствует история, нам не помощник.

Выявление противоречий наиболее короткий путь к их разрешению. А их в рассматриваемой автором проблеме более чем достаточно. 


\section{Список принятых сокращений:}

АГ - артериальная гипертензия

АРИЗ - автоматизированное решение изобретательских задач

АГТ - антигипертензивная терапия

БАБ - бета-адреноблокаторы

ГУЗ - государственное учреждение здравоохранения

ГНИЦ ПМ - государственный научно-исследовательский центр профилактической медицины

ВМП - высокотехнологичная медицинская помощь

ВВП - внутренний валовый продукт

ВУЗ - учреждение высшего профессионального образования ГД РФ - Государственная Дума Российской Федерации

ГК РФ - гражданский кодекс Российской Федерации

ГЧП - государственно-частное партнерство

ДЛО - дополнительное лекарственное обеспечение

ЕСН - единый социальный налог

$\mathrm{EC} \mathrm{-} \mathrm{европейский} \mathrm{союз}$

ИБС - ишемическая болезнь сердца

ИС - интеллектуальная собственность

КИ - клинические исследования

КЖ - качество жизни

КОАП - кодекс об административных правонарушениях

КСП-контрольно-счётная палата

ЛПУ - лечебно-профилактическое учреждение

ЛС - лекарственные средства

МВФ - международный валютный фонд

МИ - мозговой инсульт

МКБ-Х- международная классификация болезней, травм и причин смерти, 10-й пересмотр

Млн. - миллион МУЗ-муниципальноеучреждение здравоохранения НИИ - научно-исследовательский институт

НИОКР - научно-исследовательские и опытно-конструкторские работы

НК РФ - налоговый кодекс Российской федерации

Н.э - наша эра (время исчисления)

OMC - обязательное медицинское страхование 
ОП - общественная палата

ОПП - объекты патентного права

ПГГ - программа государственных гарантий

ПП - постановление правительства

ПНП - приоритетный национальный проект

ПФРФ - пенсионный фонд Российской Федерации

РАН - Академия Наук России

РФ - Российская Федерация

СД - сахарный диабет

$\mathrm{Sk}$ «кколково» - Фонд развития центра разработки и коммерциализации новых технологий в России

СМИ - средства массовой информации

СMO - страховая медицинская организация

СМП - скорая медицинская помощь

СНО - студенческое научное общество

СКР - следственный комитет России

СМИ - средства массовой информации

СС3 - сердечно-сосудистые заболевания

СРО - саморегулируемые организации

СФ ГД - Совет Федерации Государственной Думы

TRIPS - торгово-связанные аспекты защиты прав интеллектуальной собственности

Трлн. - триллион (в рублях)

ТРИЗ- технологии решения изобретательских задач

ТФОМС - территориальный фонд обязательного медицинского страхования

УК РФ - уголовный кодекс Российской Федерации

ФГУЗ - федеральное государственное учреждение здравоохранения ФИПС - федеральный институт промышленной собственности ФД - функциональная диагностика

ФР - факторы риска

ФСБ - Федеральная Служба Безопасности Российской Федерации ХОБЛ - хроническая обструктивная болезнь лёгких

ХCH - хроническая сердечная недостаточность

ЦРБ - центральная районная больница

$€$ - Евро (денежная единица ЕС)

\$ - доллар (денежная единица США) 


\section{АКТУАЛЬНОСТЬ}

Создание объектов интеллектуальной собственности в медицине достаточно сложный и продолжительный по времени процесс, при котором «...медицинская система включает предписанные нормы, которые вводятся специальными постановлениями и закрепляются законодательством, то есть институализируются» ${ }^{.}$В медицинских организациях этапами этого процесса, с одной стороны, выступает потребность врачебных кадров в разработке и применении объектов интеллектуальной собственности, с другой стороны, усиление бюрократической системы управления работой ЛПУ с большим количеством регламентирующих документов. При этом мобильность медицинской системы ограничена спецификой врачебной профессии, для овладения которой нужны большие материальные и временные затраты ${ }^{2}$. В этой связи возникает необходимость в формировании инновационной отраслевой политики в здравоохранении, где потребность в разработке и внедрении медицинских инноваций является очень высокой${ }^{3}$. Медико-социологические исследования проблемы институализации медицинских инноваций направлены на оценку общественного мнения, изменений существующих ценностей, влияния общественных

${ }^{1}$ Решетников А.В. Медико-социальные системы: способы образования и сравнительный анализ. Ж.Социология медицины,1(6),2005.C.3-7.

${ }^{2}$ Ефименко С.В Социологические теории и социология медицины о взаимодействии социальных субъектов./ Ж. Социология медицины.2005.№1(6).С.17-22.

${ }^{3}$ Беляков В.К., Пивень Д.В., Антонов Д.П. /О проблемах инновационной политики в отечественном здравоохранении и необходимости создания кластеров медицинских инноваций//.Ж. Менеджмент в здравоохрании.2008.-№1.-C.4-11. 
институтов на восприимчивость к инновациям, изобретениям, обучаемости и расширению объема знаний у подчиненных 4 . «Занятие интеллектуальным творчеством и изобретательством, развивает умственные способности, улучшает душевное состояние, расширяет кругозор и приносит пользу не только врачу и врачебной профессии, но и пациентам, так как открывает дверь к прогрессу ${ }^{5}$.

Отнесение комиссией $\mathrm{OOH}^{6} \mathrm{~K}$ правам человека объектов интеллектуальной собственности, экспликация ${ }^{7}$ прав интеллектуальной собственности Всемирной декларацией интеллектуальной собственности ${ }^{8}$ в требование приложения особых усилий по обеспечению возможностей для развивающихся стран и стран с переходной экономикой, использовать нормально функционирующие и эффективные системы интеллектуальной собственности, включая оказание соответствующей юридической помощи, модернизацию ведомств интеллектуальной собственности, помощь в подготовке людских ресурсов и совершенствовании механизмов защиты, всё это подчеркивает основополагающую ценность интеллектуальных прав для развития любого общества.

Объективная ограниченность доступных природных ресурсов стран с переходной экономикой, стремительно

${ }^{4}$ Решетников А.В. Социальное управление в здравоохранении с позиций социологии медицины. Часть1. Ж. Социология медицины.2007.№1(10).c.3-7.

${ }^{5}$ Barondes J.F. New point in wondering./J.Acad.Med.,2005;80(1):62-65.

${ }^{6}$ Intellectual Property and Human Rights. A Panel Discussion to commemorate the 50th Anniversary of the Universal declaration of Human Rights. November 9.1998.Geneva:WIPO,№762(E).1999.

${ }^{7}$ Экспликация (лат. explicatio - объяснение, развертывание) - в широком смысле разъяснение, уточнение понятия, значения позиции.

${ }^{8}$ World Intellectual Property Declaration. Geneva: WIPO, №836(E). 2000. P.3. 
возрастающие общественные потребности в оптимизации экономического развития не возможны без инновационного мышления, реализуемого в объектах интеллектуальной собственности и инновациях. Инновационное мышление эксплицирует в различные виды инновационного поведения, которое направленно на систематическое создание объектов материальной, интеллектуально-духовной культуры и освоение новых способов их реализации в различных объектах и сферах общественной жизни.

Успешность развития здравоохранения, как и других сфер жизнедеятельности, предусматривает наиболее широкую экспликацию инновационного поведения в производство и освоение медицинских изделий и услуг, которые всё больше становятся объектами патентного права при модернизации здравоохранения. Сегодня Россия стоит перед необходимостью решения множества нерешенных и вновь возникающих проблем модернизации. Среди них едва ли не на первом месте - задача укрепления и совершенствования двух фундаментальных устоев инновационного развития: человеческого капитала (творческий потенциал общественного индивида, совокупности его знаний, умений, талантов и способностей) и социального капитала (потенциал общественной кооперации и солидарности, взаимного доверия и поддержки ${ }^{9}$.

В настоящее время в Российской экономике и медицине наблюдается диспропорция между политикой инновационного развития и её реальным воплощением. По мнению российских экономистов несмотря на созданную в стране современную систему использования и правовой охраны интеллектуальной собственности, она носит ограниченный и реально затратный характер, в которой не менее 90\% всех созданных и получивших правовую охрану

${ }^{9}$ Инновационная модернизация России. Политологические очерки /Под редакцией Ю.А. Красина. - М.: Институт социологии PAH, 2011. - c. 253. 
результатов интеллектуальной деятельности не обеспечивают компенсации произведённых затрат и прибыли их применения ${ }^{10}$.

На фоне заявленного в Сколково начала эпохального ${ }^{11}$ инновационного развития общества и медицины, идёт дискуссия о незавершенности разработки 4-й части ГК РФ, несовершенстве этого основополагающего для коммерциализации инноваций документа ${ }^{12}$ При этом прослеживается изменение вектора государственной политики с «направляющего» на «управляющий», в котором государство, крупные зарубежные и отечественные корпорации, используя откровенные формы интеллектуального империализма, торгуют выгодами заключаемых и действующих в «наукограде» контрактов. Одновременно на государственно-законодательном уровне отмечается недостаточное внимание решению ряда важных проблем, в числе которых - развитие девелопментализма в России, направленного на стабилизацию правого поля для адаптации субъектов патентного права к предлагаемым государством моделям легального взаимодействия с обществом в различных, включая медицину, сферах жизнедеятельности; предсказуемости действий управленческих структур, в условиях вновь вводимых нормативных документов.

Предсказуемость и результативность действия управленческих структур на повседневную деятельность и внутренние потребности практического здравоохранения обладает наиболее высоким потенциалом воздействия

${ }^{10}$ Мухопад В.И/.Интеграция интеллектуальной собственности в национальную инновационную систему России.//Ж.Патенты и лицензии. 2012., №10.,С.15.

${ }^{11}$ [Электронный ресурс]. - Режим доступа: http//community. Sk.ru/press/b/weblog/archive/2011/04/05/minzdravsocrazvitya-rf-ifond_skolkovo-zaklychili-soglashenie-o-sotrudnichestve.aspx

${ }^{12}$ Буренков Н.С. Статья 1370 ГК РФ требует изменений. Ж.Патенты и лицензии. 2012., №3.,С.19-25. 
как на показатели общественного здоровья, так и на эффективность реформ отечественного здравоохранения в целом.

Цель исследования. Социологический мониторинг принятых правительственных решений по вопросам: НП «Здравоохранение», модернизация медицины, институализация изобретательской и патентной активности практических врачей.

Для достижения поставленной цели решались следующие задачи:

1.Изучение основных предпосылок развития социологических исследований объектов патентного права в государственно-частных новациях России.

2.Анализ законодательно-правового поля проблемы реализации инноваций в медицине.

3.Исследование значимости вопросов интеллектуальной собственности в образовательном процессе будущих врачей-студентов, особенности управления интеллектуальной собственностью высшего профессионального образовательного учреждения, пути оптимизации управления интеллектуальной собственностью в здравоохранении и медицинском ВУЗе.

4.Оценка характера инновационного поведения врачей в вопросах институализации инноваций, оснащенности ЛПУ медицинским оборудованием, взаимодействия с управленческими структурами при внедрении патентных инноваций в деятельность ЛПУ.

Объект исследования: социальные предпосылки социологического исследования закодательно-правового поля интеллектуальной собственности, вопросы управления интеллектуальной собственностью в высшем медицинском профессиональном образовательном учреждении 
и практическом здравоохранении, ресурсосберегающие технологии стандартов оказания медицинской помощи.

Предмет исследования: литературные источники, материалы СМИ, опросы мнений врачей и студентов медицинского ВУЗа.

\section{Гипотеза исследования}

Условия для развития гражданского населения в России по некоторым показателям ухудшаются. Растёт доля хронических заболеваний и смертности граждан в трудоспособном возрасте, несмотря на модернизацию медицины и внедрение высоко технологичной медицинской помощи.

В июле 2016 года Росстат опубликовал данные о смертности в России за первое полугодие 2015-го. Согласно опубликованным данным, общий уровень смертности вырос относительно первого полугодия 2014 года на 2,8\% (почти на 27 тыс. смертей). В относительных показателях - смертности на 100 тыс. населения - прирост составил 2,6\%. Рост смертности отмечался по всем основным группам причин, кроме внешних: ДТП, отравлений, убийств и самоубийств, утоплений. Смертность по внешним причинам в целом снизилась на 2,5\% в год. Также отмечено снижение смертности от отдельных болезней: от кишечных инфекций (150 умерших против 156 в первой половине 2014 года), от туберкулеза (7197 против 7538), от инфаркта миокарда (33250 против 33673).

В остальных группах рост смертности следующий: 7,2\% от инфекционных и паразитарных болезней; 2,8\% по причине новообразований; 1,5\% от болезней системы кровообращения; 8,3\% от болезней органов дыхания; 8,6\% от болезней органов пищеварения; наконец, 6,6\% - от «прочих болезней». Согласно опубликованным данным 2013 года, экономический ущерб России от смертности работоспособного населения в возрасте до 60 лет из-за 
болезней системы кровообращения составил не менее 1 трлн. рублей в год ${ }^{13}$. По данным Росстата ${ }^{14}$ за 2018 год число умерших 1828910 превышало число родившихся 1604344 на 223 тыс. человек. В Волгоградской области в 2018г число умерших составило 33563 чел, а число родившихся 23563. В целом по России и в Волгоградском регионе, в частности, показатели естественного прироста населения составили минус 1,6\% и минус 3,9\% в год, соответственно.

Здравоохранение РФ остается недофинансированным, не справляется со своими прямыми задачами, из-за этого экономика несет дополнительно существенные потери. В итоговом документе состоявшегося в Аналитическом центре при правительстве РФ в мае 2013 года доклада $\mathrm{OOH} \mathrm{о} \mathrm{человеческом} \mathrm{развитии} \mathrm{в} \mathrm{России} \mathrm{отмечено:} \mathrm{размеры}$ государственного финансирования и проводимая в сфере здравоохранения политика недостаточны для решения накопившихся социально-экономических проблем. С одной стороны, расходы на здравоохранение в России в реальном выражении за 2006-2010 годы выросли в 1,4 раза. С другой стороны, эти расходы недостаточны. На протяжении двух десятилетий в стране отмечается естественная убыль населения. Ожидаемая продолжительность жизни при рождении по Волгоградскому региону в 2017 и 2018гг 67 лет среди мужчин и 77 лет среди женщин.

В российском Минздраве данные демографической статистики объясняют улучшением диагностики социально-значимых заболеваний. В тоже время недостаточно снижается вторая ведущая причина смерти от кардиоваскулярной патологии среди мужчин России

${ }^{13}$ Медики предложили уникальную программу экспресс диагностики. [Электронный ресурс].-Режим доступа: http://top.rbc.ru/ health/page4. Дата обращения 09.05.13.

${ }^{14}$ Рождаемость, смертность и естественный прирост населения по субъектам России за 2018 год. [Электронный ресурс].-Режим доступа: http://www.gsk.ru. 
трудоспособного возраста. В 1990-2010гг каждый мужчина трудоспособного возраста из 45 потенциальных лет жизни в среднем проживал 40,6. В пересчете на одного преждевременно умершего мужчину средние потери лет жизни составили 4,35. В 2010 году средние потери лет жизни оказались на 20\% выше и составили 5,23 года.При этом средние потери лет жизни от внешних причин смерти уменьшились на 0,11(человеко/годы). А средние потери лет жизни от болезней системы кровообращения возросли на 0,29 (человека/годы.Рис.1.).

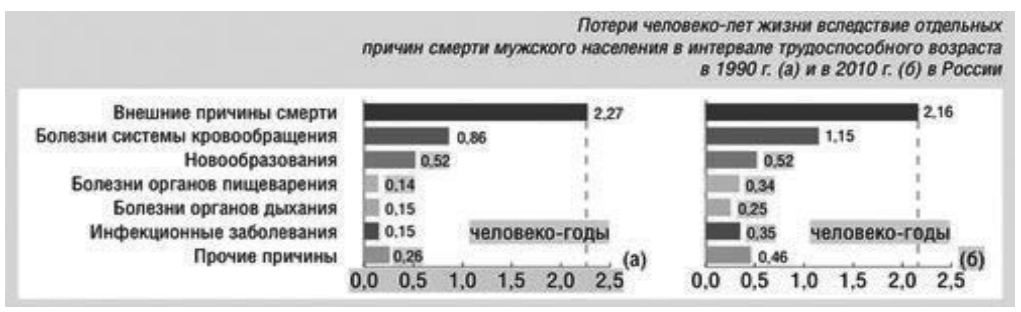

Рис.1. Доклад ООН о человеческом развитии в РФ 20132.

Происшедшие в 1990-2010гг потери человека лет жизни возросли за счёт болезней системы кровообращения, что говорит о необходимости качественного улучшения вопросов диагностики и лечения данных болезней.

Принимая во внимание передачу полномочий по обеспечению качества медицинской помощи субъектам Российской Федерации, важно проведение медико-социального мониторинга для определения качества оказания медицинской помощи больным с кардиоваскулярной патологией на местах. Актуальность проблемы улучшения качества медицинской помощи больным с кардиоваскулярной патологией требует новых научно обоснованных подходов на основе развития и использования объектов интеллектуальной собственности гражданского населения России и устранения факторов препятствующих их институализации. 
Медико-социальные вопросы реабилитации хронической кардио-васкулярной патологии наиболее значимы среди больных сахарным диабетом 2-го типа, имеющих наиболее высокий риск преждевременной смерти от кардиоваскулярных осложнений. Реализация новых масштабных проектов по оказанию высокотехнологичной помощи в регионах России путем строительства и ввода в эксплуатацию кардиохирургических центров, увеличило выживаемость этих больных. Как показал опыт развитых стран, отсутствие эффективной профилактики существенно увеличивает стоимость оказания повторной ВМП. В тоже время для этой категории больных, коморбидной кардиально-диабетической патологией, не решены вопросы профилактики осложнений, инвалидизирующих выживших пациентов. Недостаточное количество федеральных квот, ограниченные финансовые возможности кардиохирургических центров, недостаточность финансирования программ ДЛО, ограниченные финансовые возможности фондов социального страхования, дефицит местных бюджетов в значительной мере снижают эффективность работы кардиохирургических и сосудистых центров, с больными сахарным диабетом 2-го типа, имеющих высокие риски инвалидизирующих микрососудистых осложнений.

Реальная реабилитация пациентов коморбидной сердечно-сосудистой патологией,«не поспевает» за растущей инвалидизацией. При этом наблюдается снижение эффективности звеньев и этапов лечебно-профилактической реабилитации. Это, в свою очередь, порождает множество не только медицинских, но и социальных проблем снижающих потенциальную эффективность проводимых лечебно-диагностических мероприятий, включая ВМП. Особенно остро эти вопросы стоят в лечебно-профилактических учреждениях практического здравоохранения, где отмечаются недостаточная укомплектованность необходимыми специалистами, различной аппаратурой, 
недостаточность или отсутствие внедрений инновационных разработок, в том числе врачебных, на этапах медикосоциальной реабилитации.

Ожидается, публичные данные могут способствовать устранению накопившихся проблем нынешнего этапа развития Российского здравоохранения путём приоритетного развития производства медицинской аппаратуры российского производства, устранения дефицита врачебных кадров, выполнения стандартов и клинических рекомендаций оказания медицинской помощи, эффективного внедрения патентных объектов в структуру стандартов и клинических рекомендаций оказания медицинской помощи, обучения основам технологии разработки и коммерциализации объектов интеллектуальной собственности в высших медицинских профессиональных учебных заведениях, на факультетах последипломного усовершенствования врачей, поддержки интеллектуальных разработок и изобретений врачей федерально-муниципальными органами власти при участии общественных саморегулируемых организаций, профессиональных врачебных сообществ.

Автор полагает, что ускорение институализации врачебных и медицинских новаций, в области наиболее распространенной сердечно-сосудистой патологии, будет способствовать улучшению демографических и социальноэкономических показателей продолжительности, качества жизни населения Волгоградского региона и России в целом.

\section{Научная новизна}

Выполнен комплексный социологический анализ проблемы реализации инноваций в российской медицине, с дескрипцией на кардиоваскулярную патологию, превалирующую в структуре демографических и социальноэкономических потерь России.

Впервые проанализированы предпосылки социологического исследования объектов патентного права в 
российском медицинском обществе. Одновременно выполнен анализ псевдоинноваций в клинико-фармацевтической области ряда зарубежных и российских новаций.

Проведен комплексный анализ социально-экономических и законодательных причин, препятствующих успешному внедрению в практическое здравоохранение инновационных Российских лечебно-диагностических вмешательств и аппаратуры. При этом установлен позитивный медико-социальный и экономический потенциал инновационных разработок медицинской аппаратуры и лечебно-диагностических вмешательств, все больше являющихся объектами патентного права в экономике, культуре и медицине России.

Также изучены мнения специалистов кардиологов, эндокринологов и терапевтов общегородской лечебной сети города Волгограда по вопросам институализации средств реабилитации пациентов с кардиоваскулярной патологией, являющихся объектами патентного права в Российском здравоохранении. При этом первые установлено, что врачи специалисты недостаточно часто используют патентные методы реабилитации, отсутствует поддержка внедрения врачебных разработок муниципальными, региональными органами власти и управления здравоохранением.

Исследовано мнение студентов выпускного курса медицинского вуза по вопросам использования медицинских инноваций в образовательном процессе, проведена оценка знаний студентами разделов ГК РФ, регламентирующих коммерциализацию патентных инноваций в обществе и медицине.

Автором разработана и представлена структура эффективного управления интеллектуальной собственностью в ВУЗе и практическом здравоохранении, предложены концепции: внедрения в образовательные технологии базового и последипломного образования вопросов 
технологий решений изобретательских задач; совместной работы профессиональных врачебных сообществ с департаментом анализа, прогноза и инновационного развития здравоохранения РФ; совместной работы профессиональных врачебных сообществ со страховыми медицинскими организациями, региональными и федеральными органами здравоохранения, с целью оптимизации и координации вопросов внедрения и эффективного применения интеллектуальной собственности в практическом здравоохранении. 


\section{Введение}

На фоне экономических проблем внутреннего и внешнего характера, демографические потери населения России - это один из краеугольных вопросов развития страны, возможностей выживания народа ${ }^{15}$. Вклад сердечно-сосудистых заболеваний в общую смертность населения России составляет 57 \%. ССЗ - наиболее частая причина госпитализаций и потерь трудоспособного населения РФ. Экономический ущерб от ССЗ в РФ в 2007 году составил 2,8 \% внутреннего валового продукта (ВВП) страны. Прогнозируется увеличение ущерба к 2015 году $^{16}$. Коэффициент смертности от болезней системы кровообращения в развитых европейских странах в среднем в 4 раза ниже. По ведущим нозологиям смертность мужчин трудоспособного возраста в России от ИБС более чем в 10 раз выше европейской, от мозгового инсульта (МИ) - в 6 ра $3^{17}$. Роль артериальной гипертонии как одного из ведущих факторов риска развития инсульта, инфаркта миокарда, сердечной недостаточности, кардиальной смерти

${ }^{15} \mathrm{~B}$ Общественной палате обсудили предотвращаемые потери населения России. [Электронныйресурс].-Режим доступа: http: // www.univadis.ru/medical_and_more/Local_Medical_News_Detail?link=/ RU/Local_Medical_News/V-Obschestvennoj-palate-obsudilipredotvraschaemye-poteri-naseleniya-Rossii/(language)/rusRU\&id=933903. 31.01.2013.

${ }^{16}$ Статистический сборник "Краткосрочные экономические показатели Российской Федерации”, Госкомстат России.Москва, 2008.

${ }^{17}$ Bertuccio P, Levi F, Lucchini F, et al. Coronary heart disease and cerebrovascular disease mortality in young adults: recent trendsin Europe European Journal of Cardiovascular Prevention \&Rehabilitation August 2011 18: 627-634. 
существенна ${ }^{18}$, контроль её недостаточно эффективен. По данным мониторинга РФ за эпидемиологической ситуацией 2008 года адекватный контроль АГ составил лишь 19,1\%.Статистические данные за 2010 год свидетельствуют, что достижение лучшего в США, в сравнении с Россией, $50 \%$ уровня контроля АГ не сдерживает среди населения США темпов распространения и роста смерти от сердечно-сосудистых заболеваний и их осложнений ${ }^{19}$.

Вопросы улучшения профилактики эндемичных ССЗ для России сегодня важны как никогда. По мнению директора ГНИЦ профилактической медицины Минздрава РФ, главного специалиста по профилактической медицине Минздрава России Сергея Бойцова, существующая система профилактики различных заболеваний в стране устарела. Несмотря на то, что при Минздраве действует соответствующий департамент, а в 55-ти субъектах РФ есть центры медицинской профилактики, они являются малоэффективными ${ }^{20}$.

Частота АГ у больных СД тип 2 выше популяционной. Главное место в структуре смертности больных СД занимает сердечно-сосудистая патология: $54,7 \%$-ОИМ, $29 \%$-инсульт ${ }^{21}$. У мужчин, страдающих СД тип 2 , внезапная

${ }^{18}$ Erbel R,Lebmann N,Möblenkamp S et al./Subclinical coronary atherosclerosis predict cardiovascular risk in different stages of hypertension:result of the beinz nixdorf recall study/Hypertension 2012;59(1):4453.

${ }^{19}$ Egan B.M.,Zbao, Neal Axon R et al. US trends in prevalence,awareness, treatment,and control of hypertension 1988-2008.J AMA 2010; 303:2043-50.

${ }^{20} \mathrm{~B}$ Общественной палате обсудили предотвращаемые потери населения России. [Электронный ресурс].-Режим доступа: http: // www.univadis.ru/medical_and_more/Local_Medical_News_Detail?link= /RU/Local_Medical_News/V-Obschestvennoj-palate-obsudili-predotvraschaemye-poteri-naseleniya-Rossii/(language)/rus-RU\&id=933903. 31.01.2013.

${ }^{21} J$.Circulation:Heart Failure,2008;1:147-9. 
смерть развивается на 50\%, у женщин на 30\% чаще, чем у лиц соответствующего пола и возраста без сахарного диабета ${ }^{22},{ }^{23},{ }^{24}$.

Исследования системы ОМС Кемеровской, Московской и Нижегородской областей Российской Федерации по оплате медицинских услуг, отпущенных больным СД тип 2 в амбулаторных условиях, условиях круглосуточного и дневного стационаров, показали рост расходов за три года в 2,4 раза от суммарных финансовых затрат, существенно опережая темпы роста общих финансовых расходов ОМС на лечение всех застрахованных пациентов ${ }^{25}$.

Опережающие темпы роста финансовых расходов системы OMC на лечение больных СД в сравнении с другими категориями больных, категорически высокие показатели сердечно-сосудистой смертности в российской популяции, превышающие в несколько раз Европейские, свидетельствуют о недостаточной технологической эффективности лечебно-профилактической помощи в РФ, в то время как здравоохранение экономически развитых стран становиться технологически более эффективным.

В РФ последние годы закупалось, до введения экономических санкций, больше технологически сложного

${ }^{22}$ Manson JE,Colditz GA,Stampfer MJ et al.Prospective study of maturety-onset diabetes mellitus and risk of coronary beat disease and stroke in women./Arch Intern Med 1991;151:1141-7.

${ }^{23}$ Neaton JD,Wentworth DN,Culter J et al.Risk factors for death from different types of stroke.Multiple risk Factor Intervention trial Reasearch Group/Ann Epidimiol 1993;3:493-9.

${ }^{24}$ Stratton JM,Adler AI,Neil AW et al.Association of glycaemia with macrovascular and microvascular complication of type 2 diabetes (UKPDS 35):prospective, observational study.BMJ 2000;321:405-12.

${ }^{25}$ Трясучев И. О., Антонова Г. А., Пачгин И. В., Хлабутина Е. И. Приоритетный национальный проект и концепция развития здравоохранения, общие экономические вопросы, бюджетные средства и ОМС. Ж. «Здравоохранение», №11-2009., С.23-28. 
лечебно-диагностического оборудования, такого как компьютерные и магниторезонансные томографы, следящая, ЭКГ, УЗИ и лабораторно-диагностическая аппаратура. Международный рынок медицинской аппаратуры большой, но приобреталось её в РФ недостаточно. Во время октябрьского 2012 года визита президента РФ В.В.Путина в Тверскую область руководители инспектированных медучреждений на вопрос обеспеченности новым медоборудованием отвечали:«...оборудование есть, закупается, но не в таком достаточном объеме, как хотелось бы» ${ }^{26}$. В силу ограниченных возможностей финансирования здравоохранения из бюджетов всех уровней в ближайшей перспективе удовлетворение потребностей отечественного здравоохранения в необходимом российской медицинском технологичном оборудовании выглядит проблематичным.

В тоже время немало российских изобретений в области кардиоваскулярной патологии, несмотря на свою социально-экономическую актуальность, не имеет широкого практического внедрений и применения. В действительности, мало кто занимается качественным анализом изобретений в сфере медицинских услуг, которые могут быть включены в государственные инвестиционные проекты. Качественный отбор изобретений осуществляет Роспатент, точнее отраслевые отделы ФГУ ФИПС, ежегодно публикуя 100 лучших изобретений РФ. Однако их работа недостаточно эффективна. Вопросы успешного внедрения, отбора лучших изобретений и определение места их на рынке услуг лучше решаются частным предпринимательством, которое не использует достаточно благоприятных условий и стимулов для применения изобретений в российской экономике и медицине. Иностранные ловцы инноваций скупают российские изобретения за бесценок, так как обладатели патентных прав не имеют достаточно

${ }^{26}$ [Электронный ресурс]. - Режим доступа: http://www.radiomayak. ru/news/show/id/33317.12-10-2012. 
финансовых средств для их законодательной защиты и поддержки за пределами России. При этом отсутствует поддержка физических лиц правообладателей патентов государственными и общественными институтами, достаточно медленно создается благоприятный государственный инвестиционно-инновационный климат. Это подтверждают данные годовых 2006-2010 гг отчётов Роспатента, согласно которым из 209,5 тыс. выданных патентов на изобретения, полезные модели и промышленные образцы лишь 9,4\% были коммерциализированы путём заключения лицензионных договоров и соглашений об отчуждении патентов ${ }^{27}$. Очевидной проблемой модернизации российской экономики и медицины является не только дефицит охраны патентных результатов интеллектуальной деятельности, но и крайне низкая их коммерциализация во всех отраслях экономики и производства, включая медицину.

Достаточно серьезной проблемой успешной модернизации медицины является построенная не на должном уровне работа служб ЛПУ: затрудненный в силу слабой организации доступ к медицинской документации в архиве, ненадежная работа лабораторий, отсутствие необходимого оборудования и уровня сертификации ${ }^{28}$. Эти проблемы остаются актуальными, несмотря на предпринятые исполнительными органами власти определённые шаги в обеспечении отдельных регионов федеральными субсидиями для введения электронного правительства. В структуру электронного правительства входит система электронного межведомственного документооборота, создание единой точки входа на сайты органов государственной власти и обеспечение взаимодействия между уже

${ }^{27}$ Годовой отчёт Роспатента за 2010 год.М.:Роспатент,2010.

${ }^{28}$ Федорова Г.В.,Редькин А.В. Диагностическая служба в лечебнопрофилактических учреждениях Омска// Проблемы социальной гигиены, здравоохранения и истории медицины.-2009.-№1.-С.51-53. 
имеющимися ведомственными информационными системами. Согласно постановлению правительства №560, субсидии предоставлялись на условиях софинансирования, при этом максимальная сумма, выделенная на условиях конкурса отдельному региону из федерального бюджета, не превышала 50 млн. рублей. В 2012 году на конкурс было подано 74 заявки на общую сумму около 2,4 млрд. рублей. До конкурса было допущено 48 заявок, из которых финансовое обеспечение получили лишь 22 проекта.

Остальные регионы, а их более 50-ти в числе которых город Волгоград, остались без федеральных денег, так как заявленные чиновниками министерств здравоохранения сроки реализации проекта не удовлетворили организаторов конкурса. В результате регионы вынуждены были тратить на эти цели дефицитные средства местных бюджетов ${ }^{29}$.

Недостаточная оснащенность ЛПУ современным медицинским оборудованием препятствует успешному осуществлению клинических исследований (КИ) из-за отсутствия в регионах нужного в соответствии с требованиями протоколов КИ оборудования. Достаточно же оснащены для проведения некоторых современных КИ единичные региональные ЛПУ. Дефицит в регионах высокотехнологичного медицинского оборудования сдерживает процесс расширения практики КИ и удорожает их выполнение.

В качестве альтернативы собственной лабораторной службы лечебных учреждений предлагается аутсоринг. Создание укрупненных аутсоринговых центров обслуживающих лабораторные потребности лечебных учреждений, также как и совместное использование редкого дорогостоящего медицинского оборудования имеющегося в одном из ЛПУ исследовательскими центрами, расположенными

${ }^{29}$ Волгоградская область осталась без федеральных денег на электронное правительство. [Электронный ресурс].-Режим доступа: http://v102.ru/news/37150.html.08.12.2012. 
на базе нескольких ЛПУ, несет угрозу монопольно высоких цен медицинских услуг, снижение их доступности ${ }^{30}$.

Постановление Правительства РФ от 13.01.1996 №27 «Об утверждении правил предоставления платных медицинских услуг населению медицинскими учреждениями» регулировало порядок их использования недостаточно эффективно. Вновь организуемые частные медицинские организации оказались втянутыми в неравную конкуренцию с государственными и муниципальными учреждениями, так как последние работали в условиях, созданных за государственный счет, и почти все финансовые средства, получаемые ими от граждан, являлись их чистой прибылью. Вышеназванное постановление правительства фактически трансформировалось в тормоз развития практического здравоохранения ${ }^{31}$. В новом постановлении правительства ПП №1006 от 04 октября 2012 года «Об утверждении правил предоставления медицинскими организациями платных медицинских услуг» надзор за их представлением с 1-го января 2013 года осуществляет Росздравнадзор, получивший право административного наложения штрафов при выявлении нарушений. Новое постановление правительства (ПП) не урегулировало вопрос неравной конкуренции государственного и частного секторов оказания услуг медпомощи.

Обращают на себя внимание цены в государственных и частных учреждениях здравоохранения, различие которых довольно существенно. В настоящее время конкуренция между частными клиниками на рынке практически отсутствует, в основном конкуренцию частным

${ }^{30}$ Собственная лабораторная служба или аутсоринг? Ж.Менеджер здравоохранения .2010. №12. С.46-49.

${ }^{31}$ Саверский А.В., Панов А.В. Правомерность платных медицинских услуг в государственных и муниципальных учреждениях здравоохранения. Ж.Правовые вопросы в здравоохранении. 2010. №1.-C.20-30. 
медицинским учреждениям составляют государственные ЛПУ, которые также начали активно развивать платные медицинские услуги. В числе конкурентных преимуществ государственных ЛПу - оказание услуг по демпинговым ценам, в связи с чем на сегодняшний день они занимают весь нижний и часть среднего ценового сегментов на рынке платной медицины ${ }^{32}$.

По данным М. Ю. Миловатской (2010) объём платных медуслуг в России с 2003 по 2010 годы рос опережающими темпами по отношению к доходам населения и инфляции, что в значительной степени отразилось на стоимости.

Ориентация на более высокие цены медуслуг предполагает работу с другим ценовым потребительским сегментом. Если повышение цен не сопровождается соответствующим повышением уровня сервиса и качества услуг, оно может вести к потере менее платёжеспособных пациентов без притока новых. Зачастую частным клиникам для получения прибыли выгоднее ориентироваться на высокие цены и низкий спрос со стороны обеспеченных клиентов, чем наоборот. Поэтому верхний ценовой сегмент рынка медицинских услуг сегодня наиболее насыщен частными клиниками. Вероятнее всего, в ближайшие годы данная тенденция сохранится, а активный рост цен продолжится.

По данным исследования SCR Group 332012 года число клиентов платной медицины в России составило 82 млн. человек. Средний темп ежегодного прироста клиентов платной медицины составляет около 1,5\%.В

${ }^{32}$ Миловатская М.Ю. Статистический анализ поведения цен на российском рынке платных медицинских услуг в условиях кризиса 2008-2010.Аудит и финансовый анализ.2010.,№5.

${ }^{33}$ По данным исследования SCR Group, ежегодный темп прироста клиентов платной медицины составляет $1,5 \%$, а значит, к 2016 году их число достигнет 87,4 млн чел. http://zdravkom.ru/news/ issledovanie-milliony-rossiyan-golosuut-svoim-koshelkom-za-platnuyumeditsinu/ Добавлено: 13 декабря 2012. 
пик кризисного периода наблюдался отток клиентов. Восстановление докризисных показателей потребителей коммерческой медицины наблюдается с 2010г. Прогнозировался рост в последующие пять лет числа потребителей платной медицины. При таком прогнозе в среднем на 1,5\% ежегодно число клиентов платной медицины к концу 2016 года могло составить 87,4 млн. человек, что более половины населения России.

В связи с достаточной насыщенностью верхнего ценового диапазона рынка платных медуслуг и прогнозируемым его ростом конкуренция частного и государственного здравоохранения возможна за счет оптимизации состава услуг и обоснованного выбора приоритетных направлений развития. При неправильном выборе развития государственного здравоохранения возможно снижение обращений за бесплатными видами государственной медицинской помощи и рост обращения к услугам платной медицины, несмотря на её дороговизну.

По данным «Левадо-Центра» и ВЦИОМ более 90\% опрошенного в конце 2011 года населения России были недовольны системой российского здравоохранения ${ }^{34}$. По данным социологических опросов проведенных в июне 2012 года холдингом РОМИР 351000 респондентов старше 16 лет в городах с населением более 100 тысяч платными медицинскими услугами, по причине неудовлетворённости госбюджетной системой здравоохранения, пользовалось $2 / 3$ интервьюированных лиц. При этом $52 \%$ респондентов оплачивали медуслуги за свой счет, потратив в среднем за год 8700 руб.(в 2005г.- 5600 руб.).

${ }^{34}$ Астафьева Н.Г.,Кобзев Д.Ю.Между верой и знанием.Ж.Лечащий врач, июнь 2012,№6.С.61.

${ }^{35}$ Ведомости - Услугами платной медицины пользуются уже две трети россиян. [Электронный ресурс].-Режим доступа: http://www. romir.ru/press/538_28.06.2012/ 
Клиентами в сфере платных медуслуг в основном были женщины-75\% против 60\% мужчин, чаще в возрасте до 35 лет, а также россияне со средним и высоким уровнем доходов. Заметное положение в тройке специалистов сферы платных медицинских услуг занимают стоматологи и гинекологи (74\% и 23\%), уступают им терапевты (17\%), (Рис.1).

Результаты более раннего 2004г маркетингового исследования объёма и качества предоставляемых платных медицинских услуг среди 2037 тыс.чел. наиболее крупных городов Краснодарского края выявили аналогичную данным РОМИРа структуру обращаемости к специалистам платных медуслуг: к стоматологам (32\% всех обращений), терапевтам (25\%) и гинекологам $(21 \%)^{36}$. Обращает внимание схожесть данных результатов исследований 2004г и 2012г рынка платных медуслуг для населения двух разных регионов России, где платные услуги терапевтов заняли места в первой тройке специалистов.

\footnotetext{
Платными медицинскими услугами в каких областях вы пользовапись за последние 12 месяцев? В \% от тех, кто пользовапся платными услугами. (возможно несколько вариантов ответов, поэтому сумма не равняется 10о\%)

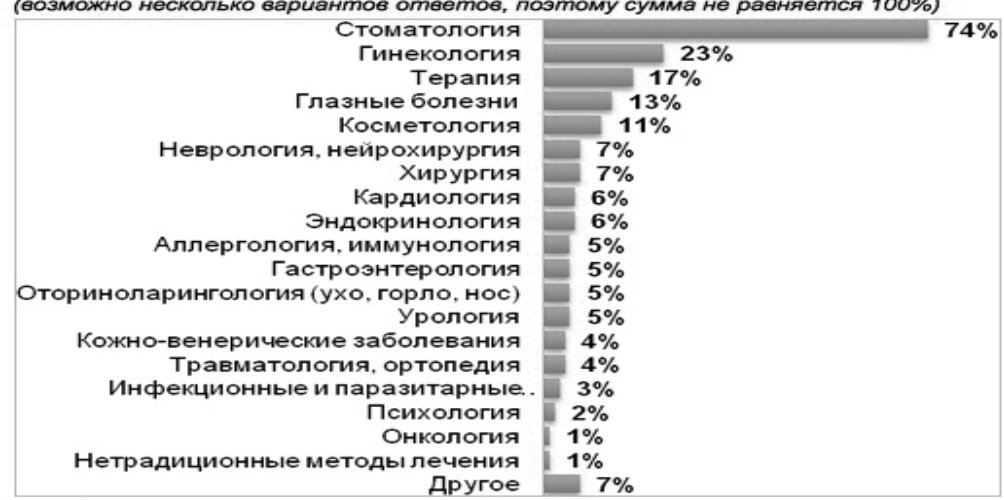

Источник: Холдина Ромир, июнь 2012 Другое $7 \%$

Рис.1.Структура платных услуг в зависимости от профиля оказанной медищинской помощи.

${ }^{36}$ Алексунин В.А.,Митьков С.А.Социальные аспекты платных медицинских услуг.Ж.Социология здоровья и медицины.2006.
} 
Население России по официальным данным тратит на медицинскую помощь и лекарства около полумиллиарда рублей ежегодно.Эти деньги россияне тратят несмотря на гарантированную Конституцией бесплатную медицинскую помощь. Это свидетельствует о недостаточной эффективности последней и всё большей обращаемости населения трудоспособного возраста в сферу платных медуслуг к терапевтам с коморбидно-растущей кардиоваскулярной патологией.

Несмотря на устойчивый спрос платных видов терапевтической помощи госбюджетная медицина сегодня сохраняет свою доминирующую позицию на российском рынке медицинских услуг. Однако обращаться к ней часто стремятся лишь в самых тяжелых ситуациях, например, в случае осложненных течений заболеваний. Эта тенденция негативно сказывается на качестве жизни: лечение домашними средствами в кругу семьи и близких становится важнейшей практикой социальной адаптации больных, что не может реально улучшить состояние их здоровья, поскольку не предоставляет доступа к необходимым профилактическим здоровье сберегающим ресурсам, которые в модернизированном обществе возможны лишь через институциональную среду. Данные выполненных научных исследований указывают на то, что показатели заболеваемости по уровню обращаемости за медицинской помощью в 2-4 раза выше среди людей не проходивших регулярного обследования на ультразвуковом оборудовании. Среди пациентов выполнивших такое обследование показатели группового здоровья, включая инвалидность и уровень заболеваемости, значительно лучше, чем среди необследованного населения ${ }^{37}$. Исходя из данного факта целесообразно создание действенной

${ }^{37}$ Левина-Отставнова Н.Н. Проблема социальной оптимизации услуг в сфере УЗИ-диагностики населения на региональном уровне. Автореф дисс... канд мед.наук.Волгоград, 2003.22с. 
системы профилактического обследования населения, в том числе на УЗИ оборудовании медицинской диагностики, для распознавания болезней и проведения курсов лечебно-профилактических мероприятий на ранних стадиях социально-значимых заболеваний. В тоже время вопросы кадрово-финансовых возможностей, укомплектованности доступным диагностическим оборудованием, трудностей медицинских инноваций в большинстве выполненных научных исследований освещены недостаточно.С другой стороны ширится институализация услуг народных целителей через средства массовой информации и интернет, гарантирующих каждому заочно обратившимся «полное устранение» социально-значимой патологии ${ }^{38}$.

Сегодня Россия нуждается не просто в модернизации и информатизации, а в «креативной составляющей» модернизации, главный смысл которой в переходе к инновационному типу развития (ИТР) через «умную экономику и медицину» основанных на знании, научно-обоснованных рекомендаций по информатизации общества и творчестве квалифицированных специалистов профессиональных врачебных сообществ. При этом ИТР требует не только высокого технологического «прорыва», но и трансформации социально-политической системы с увеличением роли в управлении государством саморегулируемых общественных и профессиональных врачебных ассоциаций.

Для современного российского общества характерно противостояние между потребностью в инновационном способе развития и преобладающими политическими трендами его реализации. При этом темпы и результаты продвижения к ИТР во многом определяются коллизиями

${ }^{38}$ Интернет Сайт Хаджи Бызылхана Дюсунова. [Электронный ресурс].-Режим доступа:htpp: // vilechitsya.org /1/ serdce.html ?utm_source =advertlink\&utm =tizer\&utm_term_medium=tizer\&utm term=sedce\&utm_compaign=serdce_41.Дата обращения 20.10.12. 
авторитарных и демократических тенденций в социально-экономическом развитии России ${ }^{39}$.

В связи с необходимостью инновационного типа развития медицины России представляется необходимым и социально обоснованным социологическое исследование законодательно-правовых, экономических и социально-культурных особенностей институализации человеческого капитала в российской медицине в современных социально-экономических условиях.Особого внимания заслуживают патентованные инновационные лечебно-диагностические способы и методы, формирующие институциональную среду доступа населения к необходимым инновационным лечебно-диагностическим ресурсам при социально-значимой сердечно-сосудистой и эндокринной диабетической патологии.

${ }^{39}$ Инновационная модернизация России. Политологические очерки /Под редакцией Ю.А. Красина. - М.: Институт социологии PAH, 2011. - с. 253. 


\section{Глава 1. Обзор литературы}

\section{1. Предпосылки развития социологических исследований инноваций в здравоохранении России}

«Сегодня перед нашей страной стоят большие задачи - ускорить процесс роста экономических показателей, увеличить объёмы промышленного производства, стимулировать развитие науки и культуры, ликвидировать бедность. Я уверен: наши дети станут свидетелями истинного расивета России» ${ }^{40}$

Одной из глобальных проблем здравоохранения большинства стран, независимо от политического и экономического пути их развития, является необходимость постоянного увеличения расходов на обеспечение медицинского обслуживания населения, создание, распространение и использование инноваций - совокупности новых идей и предложений, которые потенциально могут быть осуществлены при условии масштабности и эффективности результатов их использования. Однако для систем здравоохранения различных стран эти явления имеет свои особенности. В системе российского здравоохранения в качестве основных социальных факторов, способствующих инновационным процессам можно выделить демографические, экономические и законодательно-правовые.

По глубокому убеждению гендиректора ВТО Паскаля Лами, перед Россией как участницей ВТО в действительности стоят три основных вопроса ${ }^{41}$. Во-первых, где

\footnotetext{
${ }^{40}$ А.Ф.Цыб, академик РАМН. Партнёры, общественная палата РФ. 2010.

${ }^{41}$ Дорофеев Р. Что нам делать в ВТО? Вопрос риторический. [Электронный ресурс].-Режим доступа: http://www.km.ru/ economics/2013/01/18/peregovory-o-vstuplenii-rossii-v-vto/701812chto-nam-delat-v-vto-vopros-ritoric.
} 
Россия может создать добавленную стоимость. Во-вторых, РФ нужно понять, как скомбинировать свои ведущие направления, чтобы стать конкурентоспособной. И, наконец, в-третьих, России нужно решить демографическую проблему, потому что речь здесь идет о человеческом капитале, без которого первые два пункта лишены смысла.

Действительно, в качестве главного вызова системе здравоохранения РФ до 2020 года выступает проблема демографии, включающая высокую смертность от внешних причин и болезней системы кровообращения, сокращение численности граждан трудоспособного возраста на 11 млн., увеличение доли пожилого населения до $26 \%$ и числа инвалидов до 9\%, сокращение числа женщин детородного возраста на 15\%; экономические - усиление дифференциации регионов и доходов населения, нарастание бедности ${ }^{42}$ в результате воздействия экономического кризиса, резкого роста затрат населения на ЖКХ, продукты питания, снижения доступности медпомощи и недостаточного финансирования социально-экономических проектов из бюджетов всех уровней.

Динамика изменения возрастной структуры населения России характеризуется уменьшением числа лиц молодого возраста и ростом возрастной группы 60 лет и старше. На 1-е января 2009 года в России зарегистрированы 12,7 млн. инвалидов (9\% населения). Всего в последние годы в структуре первичной инвалидности преобладают заболевания системы кровообращения (37\%).

По пессимистичному варианту прогноза Росстата численность населения РФ к 2020 году сократится на 5,3 млн. человек. По нормативному (высокому) варианту прогноза, то есть с учетом мероприятий государственной политики, направленной на улучшение ситуации, число

${ }^{42}$ Галанова Г.И.Демографические вызовы России системе национального здравоохранения. Ж.Менеджер здравоохранения.2011.№3.C32-42. 
граждан РФ возрастет лишь на 2 млн. человек и составит 144 млн. человек. ${ }^{43}$

Постарение населения, безусловно, является глобальной проблемой. Однако в развитых странах возрастание в возрастной структуре населения доли людей пожилого и старческого возраста происходит вследствие увеличения продолжительности жизни, а в России в связи с низким уровнем рождаемости и высоким уровнем обшей и детской смертности. Для сохранения числа родившихся на уровне 2008г (1713,9 тыс. человек) в 2015г значение суммарного коэффициента рождаемости должно составлять 1,66; в 2020г.-1,95; В 2009 году суммарный коэффициент рождаемости составил 1,5 ребенка на одну женщину репродуктивного возраста. Для прекращения естественной убыли населения (при сохранении нынешнего уровня смертности) требуется достижения ещё более высоких показателей рождаемости: к 2015г.-2,14; к 2020г.-2,55; С учетом прогнозируемого15\%-госнижения в РФ к 2020 году популяции женщин репродуктивного возраста достижение требуемых показателей рождаемости в принципе маловероятно. По международным критериям, население считается старым, если доля людей в возрасте 65 лет и более превышает 7\% от всего населения. Это означает, что Россия, по критериям ООН, характеризуется высоким уровнем старости (от16 до 18\%). Постарение населения ведет к изменению структуры заболеваемости и смещению акцентов на лечение хронических заболеваний, включая широко распространенную артериальную гипертензию (АГ), сахарный диабет (СД), терапия которых имеет недостаточную экономическую отдачу для общества в целом.

Среди экономических факторов нужно выделить недостаточный уровень развития макроэкономики, который

43Улумбекова, Г.Э. Анализ демографии и показателей здоровья населения РФ в динамике с 1990 г. в сравнении с зарубежными странами и некоторые прогнозы до 2020 г./Ж. Репродуктивное здоровье детей и подростков. - 2010.,№ 2.,С. 32-40. 
не позволяет осуществлять адекватное финансирование здравоохранения России и тем самым систематическое недофинансирование не обеспечивает полного соответствия здравоохранения не только международным, но и внутренним стандартам. Состояние хронической нехватки материальных ресурсов усугубляет инфляция, мировой экономический кризис, антироссийские экономические санкции, преодоление последствий которых внесёт свои негативные социально-экономические последствия. После вступления России в ВТО государственные власти устремились к следующей цели-стремлению сделать страну членом Организации экономического сотрудничества и развития (ОЭСР). По данным ОЭСР отмечается большое расслоение российских регионов и отдельных групп населения по доходам. Так ОЭСР подсчитала, что $17 \%$ населения РФ страдают от бедности, в то время как у её членов этот показатель существенно ниже ${ }^{44}$ - только $10 \%{ }^{45}$. Согласно данных независимого исследования 2008 года ${ }^{46}$ опубликованных в https://newsland.com со ссылкой на www.imperiya.by в США за чертой бедности проживали 37 млн. американцев, что составило 12,7\% населения США. По данным МВФ более позднего периода времени ${ }^{47}$ в США более $14 \%$ населения страдает от бедности. В связи с российской бедностью зарубежные эксперты предлагают

${ }^{44}$ По данным Владимира Познера данный показатель в США на момент написания книги (1996г) не менее 15\%. Источник: Прощание с иллюзиями. ООО «Издательство АСТ» Москва,2016.С.75.

${ }^{45}$ Романов А.Россию призвали вернуться к прогрессивному налогообложению.[Электронный ресурс ].-Режим доступа: http:// www.km.ru/economics/2013/01/21/modernizatsiya-ekonomiki-rossii-iinnovatsii/701959-rossiyu-prizvali-vernutsya-

${ }^{46}$ США страна бедняков и нищих. [Электронный ресурс ].-Режим доступа:https://newsland.com/user/4296648026/content/ssha-stranabedniakov-i-nishchikh/3973145.Дата обращения 01.08.16.

47 [Электронный ресурс ]-Режим доступа:http://replika.com.ua/ $\mathrm{ru}$ /11_glavnaya/po_dannym_mvf_v_ssha_bolee_14_naseleniya_stradaet_ ot_bednosti. Дата обращения 01.08.16. 
изменить существующую систему налогообложения в России. От уравнительного принципа эксперты рекомендуют перейти к системе прогрессивного налогообложения, в которой состоятельные граждане платят более высокий налог. Правительство РФ не внедряет систему прогрессивного налогообложения в целях стимулирования развития экономики и из-за невысоких доходов основной части населения.

Минфин планирует рассматривать предложения по корректировке налоговой системы после 2018 года. Об этом заявил министр финансов РФ Антон Силуанов в ходе обсуждения в Госдуме проекта федерального бюджета на 2017-2019 гг. Ведомство будет готовить к рассмотрению предложение по введению прогрессивной шкалы налогообложения НДФЛ», - прокомментировал министр финансов РФ Антон Силуанов корреспонденту Накануне.RU ${ }^{48}$.

B качестве помощи малому и среднему бизнесу правительством был разработан и введён с 2013 года «Патентный» вариант налогообложения. Годовая стоимость патента определяется как произведение потенциально возможного годового дохода и налоговой ставки 6\%. Потенциально возможный доход устанавливается субъектом РФ для каждого вида деятельности и может отличаться в разных муниципальных образованиях в несколько раз. Максимальная величина потенциально возможного годового дохода не может превышать 1147000 руб. Максимально допустимый размер возможного годового дохода ежегодно корректируется на коэффициент-дефлятор. Нижняя граница потенциально возможного к получению годового дохода с 2015 г. отменена ${ }^{49}$.

${ }^{48}$ Минфин готов рассмотреть предложение по введению прогрессивной шкалы налогообложения после 2018 года. [Электронный pecypc]: http://www.nakanune.ru/news/2016/11/18/22453535\#sthash. uOp6vpiz.dpuf.

${ }^{49}$ Плюсы и минусы патентной системы налогообложения. http://www.audit-it.ru/terms/taxation/patentnaya_sistema_ nalogooblozheniya_psn.html. Дата обращения 19.11.16. 
Патентная система налогообложения (ПСН) существенно упрощала все процедуры, связанные с бухгалтерским учетом и налоговой отчетностью, однако н направлена исключительно на индивидуальных предпринимателей и применима только для них. Для её применения необходимо выполнение трех условий: а)средняя численность работников не должна превышать 15 человек; б)объем годовой выручки не должен превышать 60 млн. руб; в) ПСН не применяется в рамках договоров товарищества или доверительного управления имуществом. В случае нарушения первых двух ограничений индивидуальный предприниматель утрачивал право на применение ПСН и автоматически переходил на общий режим налогообложения.

Из законодательных факторов не на пользу демографической ситуации работает Ф3-83 от 08.05.10г.Экономические стимулы по принятому ФЗ-83 вытеснили ЛПУ в сторону платных услуг, с сокращением количество бесплатных услуг до минимума. На этом фоне возможность бесплатно лечиться в России ежегодно сокращается. В условиях сложившегося кризиса на рынке платных медицинских услуг из года в год отмечается их рост. В августе 2016 года аналитический центр при правительстве России опубликовал отчет, согласно которому единственной группой услуг, потребление которой выросло за два года кризиса, стала группа медицинских услуг - в I квартале 2016 года объем на 4,3\% превысил уровень I квартала 2014 года. Инициирует процесс сокращения бесплатных медицинских услуг и деятельность законодательных органов власти Федерального уровня.

Глава Совета Федерации Валентина Матвиенко предложила в 2016 году лишить бесплатных медицинских услуг неработающих граждан. По мнению спикера СФ ГД региональные власти не должны делать взносы за тех, кто не платит налоги и не указывает место работы. До первого октября 2016 года Минфин и Минздрав должны 
подготовить поправки в законодательство, предусматривающие сокращение бесплатных медицинских услуг для неработающих граждан ${ }^{50}$. Экспертное сообщество считает это признаком замещения бесплатной медицинской помощи платной, что явно противоречит статье 41 Конституции РФ, которая гарантирует каждому гражданину право на бесплатную медицинскую помощь в государственных и муниципальных учреждениях здравоохранения.

Страховые компании, в свою очередь, признают, что подобная инициатива СФ ГД может стать дополнительным стимулом для развития добровольного медицинского страхования (ДМС), для которого у неработающего населения должны быть «лишние»деньги.

Из-за финансово-демографического расслоения граждан РФ, население половины сельских поселений и трети малых городов России в условиях экономического кризиса без работы и бесплатной медицинской помощи, может вообще исчезнуть. По публикациям в прессе, за последние 20 лет в России исчезли около 23 тысяч населенных пунктов, из них около 20 тысяч -это сельские поселения ${ }^{51}$. По данным ООН в числе 28 наиболее вымирающих городов мира (рис 2.) 11-российских. В их числе девять с населением более 1 млн. человек, включая город Волгоград(ИA REGNUM). Население вымирающих городов и исчезающих населенных пунктов Ф3-83 и законодательная деятельность СФ ГД оставляет без широко доступной медицинской помощи. Усугубляет выше перечисленные демографические проблемы реформа здравоохранения, которая не возможна без реализации Ф3-83. В данном законе определено, что работающее в ТФОМС учреждение,

${ }^{50}$ Не даром лечимся. 19.09.2016. Электронный документ: http:/ www.fondzdorovie.ru/news/detail.php?

${ }^{51}$ Г.И.Галанова.Демографические вызовы России системе национального здравоохранения. Ж.Менеджер здравоохранения.2011.№3.С.32-42. 
не может быть «казенным», и по определению должна заниматься «приносящей доход деятельностью». По глубокому убеждению разработчиков Ф3-83 работа ТФОМСа может и должна быть прибыльной за счет не выплат со стороны СМО за оказанную медицинскую помощь ЛПУ и СМП, в том числе неработающим гражданам.

\section{1 из 28 самых вымирающих городов в мире - российские}

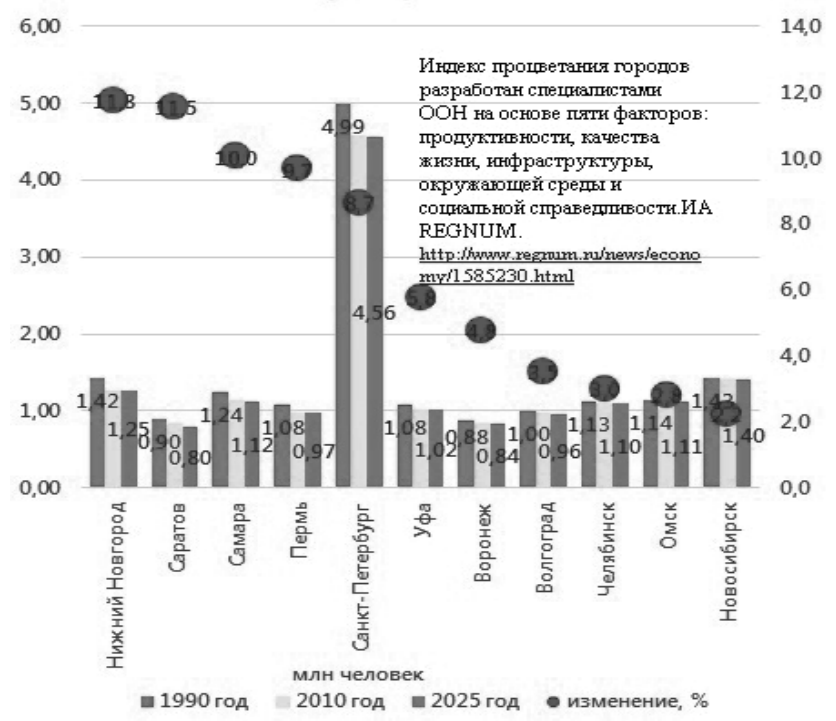

Рис.2. Самые вымирающие города России

С одной стороны, благодаря действиям общественной палаты внесены поправки в Ф3-83, касающиеся того, что переходный период действовал почти два года до 1 июля 2012 года. В начале 2013года вступило в действие отсроченное положение о «доход приносящей деятельности». Специфика Ф3-83 такова, что для его функционирования недостаточность бюджетного финансирования была не ограничением а стимулом к реализации «доход 
приносящей деятельности». При этом до конца не были просчитаны все социальные риски и последствия принятого Ф3-83. А их немало. Это отсутствие менеджерских компетенций у руководителей ЛПУ, неподготовленность подзаконных нормативно-правовых актов на уровне субъектов Федерации, не готовность финансово-нормативной базы, отсутствие нормативов подушевого финансирования медицинской помощи, несовершенство механизмов государственного регулирования затрат на медицинское обслуживание в условиях одноканального финансирования из средств ОМС, недостаточное ресурсное обеспечение стандартов оказания медицинской помощи, не разработанность стандартов по всем видам оказания медицинской помощи и ряд других.Таким образом, круг проблем касающихся медицинских инноваций в России обширен, и усугубляется сложившейся кризисной социально-демографической ситуацией и законодательной деятельностью ГД РФ местами не соответствующей положениям конституции РФ.

По мнению комиссии общественной палаты РФ по охране здоровья контроль сверху не может эффективным. Поэтому необходимо создание комиссий, которые будут контролировать соблюдение стандартов, соотношение количества и качества платных и бесплатных медицинских услуг ${ }^{52}$ Внедрение медицинских инноваций, включая врачебные, хотя и не решает существующих социальных проблем, но ведет к снижению социально-демографических потерь. Прежде всего, за счет внедрения новых и доступных лечебно-диагностических технологий. Они представлены не только различными медицинскими вмешательствами, но и инновационными методами диагностики,

${ }^{52}$ Руководитель ЛПУ в зеркале Ф3-83:Менеджер. Экономист, юрист. Круглый стол 04.02.11. Комиссии общественной палаты РФ по охране здоровья, экологии, развитию физической культуры и спорта.Ж.Менеджер здравоохранения.2011. №4. с.66-72. 
выбора лечения. За счет последних, во многом, становится возможным более раннее выявление и профилактическое лечение широко распространенных заболеваний и их осложнений. Это, в свою очередь, должно снизить частоту осложнений артериальной гипертонии (АГ),сахарного диабета (СД) и ИБС. Однако в условиях снижения доступности бесплатной медицинской помощи, особенно среди населения малых городов и сельских поселений, этого ожидать нельзя. Широкое распространение АГ,СД, ИБС, растущее снижение доступности бесплатной медицинской помощи в условиях средних, малых городов и сельских поселений в РФ способствует недостаточно высокой степени экономической отдачи высоко технологичных подходов в вопросах диагностики и лечения демографически значимой сердечно-сосудистой патологии.

Законодательно-правовые вопросы, касающиеся благоприятных условий внедрения (включая новые стандарты) недорогих российских инновационных медицинских технологий, до сих пор оптимально не решены. В частности, более чем на полгода растянут по времени процесс получения разрешения на использование вновь регистрируемых медтехнологий в Росздраве (рис.2.Приложение).И это несмотря на то, что их использование способствует более раннему выявлению хронических неинфекционных эндемических заболеваний, снижению социально-экономических потерь связанных с обострением и развитием осложнений от этих заболеваний. Перечисленные причины, а также ряд других, не менее значимых законодательно-правовых и социально-экономических факторов, вызывают увеличение ассигнований на здравоохранение, которые не пропорциональны поддержке объектов патентного права в качестве альтернативы дорогостоящим, малодоступным высокотехнологичным решениям в медицине.

Очевидно, что растущее количество медицинских новаций, все больше являющихся объектами патентного 
права, в перспективе формирования благоприятных экономических и законодательно-правовых условий, может оказаться малоэффективным без анализа регламентирующих документов, влияющих на процесс их надлежащего документального разрешения и эффективного практического внедрения и применения.

Важным шагом формирования новой инновационной политики Министерства экономического развития РФ является концепция долгосрочного социально-экономического развития России на 2008-2020гг. В этой связи возникает необходимость в формировании отраслевой инновационной политики в здравоохранении. Где потребность в разработке и внедрении медицинских инноваций остается не только очень высокой, но и в перспективе будет только нарастать ${ }^{53}$. Вместе с тем растущие объемы государственной надзорно-разрешающей функции Росздравнадзора по выдаче разрешений и контролю за применением медицинских технологий отнюдь не свидетельствуют о росте использования в медицине инновационных технологий. Чем отличаются новые и инновационные технологии? Разъяснение содержится в приказе Минздравсоцразвития России № 488 от 20 июля 2007 г. «Об утверждении административного регламента Федеральной службы по надзору в сфере здравоохранения и социального развития по исполнению государственной функции по выдаче разрешений на применение новых медицинских технологий, в котором определено, что к новым медицинским технологиям относятся впервые предлагаемые к использованию на территории РФ или усовершенствованные совокупности методов (приемов, способов) диагностики, профилактики, лечения, реабилитации, методов и средств, с помощью

${ }^{53}$ Беляков В.К., Пивень Д.В., Антонов Д.П. «О проблемах инновационной политики в отечественном здравоохранении и необходимости создания кластеров медицинских инноваций».Ж. Менеджмент в здравоохрании.2008.-№1.-с.4-11. 
которых они осуществляются, а в некоторых случаях и способы получения средств, применяемых в данной технологии. Исходя из данного определения в большинстве случаев подача заявки на регистрацию новой технологии объясняется необходимостью быстрого устранения запрета на применение организациями и учреждениями здравоохранения ранее неразрешенных Росздравнадзором но используемых длительное время известных медицинских технологий. В приказе очень кратко упомянуты сведения о роли патентов в оформлении новых медицинских технологий. В частности указано, что патент не может являться официальным разрешительным документом на использование разработанных технологий и средств в медицинской практике. Согласно основам законодательства РФ об охране здоровья граждан патентные медицинские технологии должны проходить соответствующую процедуру проверки, так как Роспатент не проводит экспертизу безопасности использования медицинских технологий, это относится к функциям Росздравнадзора. Существующая на сегодняшний день система регистрации в Росздравнадзоре по сути формальна и гарантирует исключительно отсутствие значительного вредного воздействия на организм, но не подтверждает эффективность аппаратов и методов, которые применяются в медицинской практике ${ }^{54}$. В качестве доказательства эффективности приборов производителями эксплуатируются факты клинических испытаний, которые в действительности не проводятся. Таким образом, подтверждающая документация на указанные аппараты в большинстве случаев является поддельной. Использование контрафактных приборов медицинского

54Чудо-приборы» могут изъять из продажи. Remedium 09.09.2016 URL http://www.univadis.ru/business-news/184/CHudopribory-mogut-iz-yat-iz-prodazhi?utm_source=adhoc+emails\&utm medium=email\&utm_campaign=businessnews_email_uniannoucement_ rus-ru_20161004\&utm_content=1083814\&utm_term= 
назначения, которые не должны использоваться, реализуются через сетевой маркетинг, при этом продавец-посредник уходит от ответственности за обман покупателя. В заявке на разрешение применения патентного метода лечения регистрируются конкретные лица, уход которых от ответственности вряд ли возможен, только с отягчающими последствиями для обладателей патентов и разрешений в виде статей УК РФ.

В то же время ссылка на патент не является определяющей в принятии решений на разрешение применения новой медицинской технологии ${ }^{55}$, хотя патент указывает возможных ответчиков в лице разработчика и/или патенто обладателя. Таким образом, в России подавляющее большинство медицинских технологий и аппаратов из числа зарегистрированных, не имеют«knowhow» и поэтому не являются по сути инновационными.

Проблема патентных прав последнее время остро стоит и успешно решается одной из наиболее развитых экономик мира-США. Президент США Барак Обама 16 сентября 2011 года подписал законопроект, усовершенствующий патентное право в США ${ }^{56}$. Патентное ведомство США изменило процедуру выдачи патентов и международной регистрации промышленных образцов. Подписание законопроекта обеспечивает стране конкурентную способность в долгосрочной перспективе. По словам представителей Белого дома, благодаря законопроекту, ускорится процесс рассмотрения заявок, которых накопилось около 700 тыс., что позволит быстрее создавать новые рабочие места. Новый законопроект существенно изменил процесс международной регистрации промышленных образцов

${ }_{55}^{5}$ Зубарева Г.А.Инновации в медицине и патентное право//Бюллетень сибирской медицины.-2007.№2.С.68-71.

${ }^{56}$ Обама подписал закон о патентах .Электронный документ: http://www.golos-ameriki.ru/a/obama-to-sign-patent-reform-legislati on-2011-09-16-129956613/245036.html 
при подаче заявки на патент, в частности на лицензирование дизайна различных разработок. С принятием нового закона американские компании могут патентовать свои изобретения по всему миру с помощью одной единственной заявки ${ }^{57}$. В настоящее время в международной практике для защиты патентных прав юридических и физических лиц необходима подача заявок в патентные ведомства других стран, где требуется защита прав патенто обладателей. Важно отметить, что Российские патенто обладатели должны патентовать свою интеллектуальную собственность в каждой отдельно взятой стране самостоятельно, что затратно во времени и финансово обременительно.

В патентной практике США существует проблема патентных - троллей, единственной целью создания которых, как отмечают зарубежные СМЙ${ }^{58}$, является сутяжничество в сфере интеллектуальной собственности. Патентное ведомство, по мнению президента США, будет отсекать заявки, которые можно трактовать слишком широко. На самом деле патентные тролли «столбят» перспективные идеи и разработки не только из США, но и из других стран. Верно оценивая неоглобалистские стремления американских патентных -троллей, правительство США в 2013 году решило ограничить борьбу с широко трактуемыми заявками, проведением образовательной кампании среди изобретателей, которая должна помочь грамотно отражать атаки «троллей». На что направлена данная инициатива? Ответ очевиден. Действующей администрации США необходим рост ВВП. Сторонники данной инициативы считают, что благодаря ей новые конкурента

${ }^{57}$ Новый закон о патентах облегчит подачу заявок на лицензирование разработок. Электронный документ: http://www.securitylab. ru/news/435727.php. 16:05 / 29 Декабря, 2012.

${ }^{58}$ Изгнание патентных троллей из США начинается. Электронный ресурс : http://www.vestifinance.ru/articles/28299. 05.06.2013 
способные товары будут быстрее появляться на рынке, что подстегнет рост американской экономики.

В отличие от США в России проблемы интеллектуальной собственности привлекают внимание СМИ эпизодически, последний раз в 2016 году в сфере исполнительского искусства в связи с финансовыми нарушениями в Российском авторском обществе. В тоже время большинство поступивших до 2010г в Росздравнадзор технологий РАМН не являлись приоритетными и конкурентно способными с точки зрения, как мировой, так и отечественной медицинской практики. По данным Росздравнадзора учреждениями РАMН за указанный период времени не было представлено ни одной медицинской технологии по лечению заболеваний, полученных при дорожно-транспортных происшествиях, в том числе по нейротравме, а коррекция сердечно-сосудистых болезней была представлена только кардиохирургическими технологиями.

Введение в действие приказа Минздравсоцразвития России от 20.07.2007 №488 «Об утверждении Административного регламента Федеральной службы по надзору в сфере здравоохранения и социального развития по исполнению государственной функции по выдаче разрешений на применение новых медицинских технологий», который повысил требования к документам направляемым в Росздравнадзор, привело к тому что доля разрешенных медицинских технологий от общего числа заявленных составила 50\% в 2007 году и 35\% в 2008 году $^{59}$. Обращает на себя внимание и то, что большинство заявок/патентов 2009 г. (29 из 35), на которые получено разрешение на применение, были поданы в Роспатент значительно раньше

${ }^{59}$ Регистрация изделий медицинского назначения и выдача разрешений на применение медицинских технологий в Российской Федерации..[Электронный документ].-Режим доступа: http:// www.zdrav.ru/library/publications /detail.php?ID=16202\&print=Y. Дата обращения.15.06.13. 
2008-2009 гг. (т.е. до подачи документов в Федеральную службу по надзору в сфере здравоохранения и социального развития). Это отражает логику разработчиков - сначала получение патента, и лишь затем получение разрешения на применение. Прописано также, что разработчик технологии несет ответственность за правильность её применения в практике медицинских организаций (письмо Росздравнадзора от 24 февраля 2009 г. № 01И-98/09). Регламент разрешающей процедуры применения не способствуют действиям разработчиков и обладателей разрешений на применение новых медицинских технологий, не мотивируют их к распространению и активному внедрению новых технологий в практическое здравоохранение.

За период 2008-09гг по данным руководителя Росздравнадзорного ведомства Николая Юргеля, лидирующими в получении разрешений на применение медтехнологий были травматология и ортопедия, сердечно-сосудистая хирургия, онкология, офтальмология. Недостаточный уровень разработки новых и усовершенствованных медицинских технологий был отмечен в эндокринологии, наркологии, урологии, педиатрии. При этом, по мнению Н.Юргеля, основой повышения медико-социальной и экономической эффективности функционирования системы здравоохранения в период ресурсных ограничений является поиск, разработка, внедрение и правильное применение современных медицинских технологий ${ }^{60}$. Для быстрой разработки инноваций, проведения по ним клинических разработок нужны современные высокотехнологичные информационные центры, которых в РФ недостаточно.

Кроме выше рассмотренного, оперативной разработке и внедрению инновационных медицинских технологий

${ }^{60}$ Росздравнадзор проанализировал работу по выдаче разрешений на применение медицинских технологий.[Электронный документ]. - Режим доступа: http://www.medlinks.ru/article. php?sid=36523. Опубликовано 27-05-2009. 
в России препятствует не только дефицит центров высоких медицинских технологий, но и длительное время рассмотрения разрешений на впервые регистрируемую медицинскую технологию, которая по существующему регламенту составляет 177 дней без представления дополнительной запрашиваемой информации. В случае запроса Росздравом дополнительных материалов срок принятия решения увеличивается еще на три месяца ${ }^{61,}$ т.е. достигает $2 / 3$ года (Рис.2.Приложение).

Мировой финансовый кризис и антироссийские экономические санкции ЕС внесли серьёзные коррективы в государственную поддержку социальной сферы. С одной стороны, именно социальная сфера должна оставаться основой стабильности в ситуации преодоления экономического кризиса. С другой стороны, в условиях экономической нестабильности, государство утрачивает возможность наиболее полного предоставления социальных гарантий населению в прежних объёмах. В этой связи, в рамках реализации стратегической задачи государства по повышению качества жизни своих граждан и обеспечения минимальных социальных гарантий населению, особо остро стоит вопрос о развитии российского конкурентоспособного рыночного механизма хозяйствования на базе патентных, конкурентных медицинских инноваций государственных предприятий здравоохранения, конкурирующих на этом рынке с частными российскими и зарубежными лечебно-профилактическими учреждениями.

Потребность в качественном восстановлении и поддержании здоровья населения, используя всю систему российского здравоохранения, включая и частную медицину, занимает ключевое место в совокупности социальных задач государства. В тоже время недостаточный объем

${ }^{61}$ Коваленко Т.Н.,Волокитина Е.А. Правовые аспекты новых медицинских технологий. //Ж.Правовые вопросы в здравоохранении.№1.,2010.С.10-19. 
бюджетного финансирования в российском здравоохранении, растущая потребность в разработке и внедрении медицинских инноваций, являющихся объектами патентного права, продолжительный по времени процесс получения разрешения на их применение, недостаточная доступность гарантированной высокотехнологичной медпомощи, недостатки бесплатной медицинской помощи и её финансового обеспечения, не до конца просчитанные социальные риски связанные с реализацией закона о страховой медицине, постарение населения с ростом сердечно-сосудистой патологии и смертности населения, не развитость российского конкурентоспособного рыночного механизма хозяйствования для патентных медицинских технологий - вот перечень основных социально-экономических предпосылок выполнения социологических исследований в медицине России. 


\section{2.Состояние доказательной и страховой медици- ны, особенности реализации их рекомендаций}

«Сегодня важно иметь обратную связь о реформе и реальном положении дел из разных регионов России:

будь то конкретные жизненные истории, жалобы или общий экспертный взгляд на проблему».

Председатель Комиссии по контролю за реформой и модернизацией системы здравоохранения и демографии общественной палаты РФ Н.Дайхес. ${ }^{62}$

Доказательная медицина в западном понимании - это внедрение стандартов инновационных методов диагностики и лечения, которые для России не только дороги, но и недостаточно доступны из-за экономических и организационно-управленческих причин, на которых необходимо несколько подробнее остановиться и проанализировать.

Что представляет из себя учреждение, поддерживающее внедрение рекомендаций доказательной медицины? По мнению известного специалиста по вопросу доказательной медицины Т. Григхальд ${ }^{63}-$ инововведения чаще адаптируются в крупных, длительно-существующих, функционально разветвленных, специализированных учреждениях с абсорбирующей способностью и децентрализованной структурой органов принятия решений (автономно работающие группы).

В России невозможно найти учреждения практического здравоохранения с децентрализованной структурой органов принятия решений. Не менее сложно найти и федеральные учреждения практического здравоохранения

${ }^{62}$ Общественная палата открыла «горячую линию» для жалоб на медицинское обслуживание. URL доступ http://doctorpiter.ru/ articles/6048;15:14, 19.03.2013.

${ }^{63}$ Гринхальд Т. Основы доказательной медицины: пер с англ./ под ред. Денисова И.Н., Сайткулова К.И. -3-е изд-е. М.:ГЭОТАР-Медиа, 2009.-288c. 
с достаточными абсорбирующими способностями определять, осваивать, разделять и перерабатывать новую информацию в соответствии с существующим законодательством, умением связывать ее с базой накопленных знаний и адаптировать к применению ${ }^{64}$. В России подобными возможностями обладают скорее академические, а непрактические учреждения здравоохранения.

В зарубежной литературе понимание «доказательной медицины» не сводится лишь к чтению соответствующих статей и следованию доказательному подходу. На самом деле доказательная медицина требует не только чтения нужных статей в нужное время, но предполагает изменение существующей в лечебном учреждении клинической практики и, практики других людей, что само по себе достаточно сложно. На вопросы внедрения лучшей практики влияет так называемый «человеческий» фактор. Именно значение, которое видит человек в той или иной инновации, влияет на его решение принимать её или не принимать. Часто значение инновации не фиксировано, оно может обсуждаться и изменяться, например, в результате публичных дискуссий. Кроме того решение применять инновацию в рамках медицинского учреждения часто бывает связано с другими обстоятельствами. Оно может быть зависимым от решений, принимаемых другими сотрудниками учреждения или может носить административно официальный характер, когда человеку приказывают, и он внешне формально вовлечён в процесс, а внутренне в нем не участвует.

При этом также необходимо преодолеть формальный, психологический и социальный аспекты, определяющие причины сопротивления изменениям сотрудников. Формальный аспект определяется документами, определяющими должностные обязанности, договоры найма и

${ }^{64}$ Zahra A.S,George G. Adsorptive capacity: a review, reconceptualization and extension/ Acad Manage Rev. 2002;27:185-203. 
трудовые соглашения. Психологический аспект выражается в неявной форме поведения личности в зависимости от восприятия условий труда. Социальный аспект связан с соотношением ценностей различных сотрудников, определяемых правилами, например, распределения зарплаты.

В зависимости от ситуации используют тот или иной подход к осуществлению изменений, которые помимо прочего зависят от таких факторов как: наличие и объём необходимых данных; степень управляемости и сосредоточение сил, обусловленных соотношением сил и имиджа инициаторов изменения; вида и сил сопротивления; вида изменения, его уровня и числа вовлечённых; степени вовлеченности внешних факторов; факторов риска, обусловливающих последствия изменения или его отсутствия; последствия изменению сопротивления; риск, связанный с организационными факторами изменения ${ }^{65}$.

В реальности медицинская помощь в госбюджетных учреждениях оказывается в рамках ограниченного бюджета, и поэтому при принятии клинических решений приходится учитывать финансовые затраты. Очевидного единого набора этико-психологических принципов и аналитических инструментов для согласования ограниченных ресурсов с неограниченными потребностями не существует.

В настоящее время в информационную базу лечебно-диагностических стандартов входят клинические руководства, протоколы, алгоритмы и формуляры, стандартные операции и процедуры. Клинические руководства являются продуктом деятельности профессиональных медицинских ассоциаций, и включают самые современные инновационные технологии, включая патентно-воплощенные в дорогостоящее лечебно-диагностическое оборудование, в стоимость которого они входят. Больничные формуляры исходят из реальной лечебно-диагностической

${ }^{65}$ Санто Б. Сила инновационного саморазвития. Инновации. -2004.-№2,c5-15. 
базы медицинского учреждения и, как правило, не могут быть ориентированы на недоступные конкретному ЛПу дорогостоящие инновационные медицинские технологии, необходимые для оказания ВМП. К тому же больничные формуляры со временем тормозят внедрение достижений инновационной и доказательной медицины в практику, так как процесс принятия нового стандарта помощи, приемлемого для конкретного медицинского учреждения, формулярной комиссией растягивается на долгий ряд лет.

На ранних стадиях принятия решения формулярной комиссии нужна практическая информация по воплощению инноваций на рабочем месте. По мере обретения уверенности в нововведении необходима развивающая и адаптирующая информация. Можно ли, например, приспособить нововведение к конкретным условиям работы? Если да, то как? Как правило, больничные формуляры не содержат прямых ответов на данный вопрос. Поэтому больничные формуляры не достаточно эффективны для разработки и внедрения инновационных методов оказания медицинской помощи.

Право на бесплатную медицинскую помощь зафиксировано в виде конституционного права граждан РФ (ст.41 Конституции РФ). Обращает на себя внимание ограниченная доступность высокотехнологичной медпомощи (ВМП)вне квот даже в крупных медицинских центрах федерального и регионального уровня. В течение нескольких лет потраченных на выполнение данного исследования Министерство здравоохранения России, для обеспечения конституционного права российских граждан на бесплатную ВМП, изменило финансирование квот из регионального и частично федерального бюджетов.

Возникает вопрос возможностей адекватного финансирования региональными бюджетами без федеральных квот плановых и, главное, неплановых больных нуждающихся в дорогостоящей профильной ВМП? 
В этом вопросе Россия планировала перенять Турецкий опыт ${ }^{66}$. В Турции до попытки военного переворота 2016 года отсутствовала система квотирования медицинских услуг населению, включая высокотехнологичную медицинскую помощь. Государство практически полностью возмещало расходы по ВМП из средств ОМС. По программе c 01.01.2012 года каждый турецкий и иностранный гражданин обязан был быть застрахован органами обязательного медицинского страхования и получить полис SGK (аналог российского ОМС) ${ }^{67}$.

Используя опыт финансирования ВМП из ОМС других стран, Минздрав России с февраля 2013 года разделил финансирование ВМП на источники из федерального бюджета(«эксклюзивная») и из фондов ОМС («дорогостоящая»). Однако, по мнению главы Минздрава России Вероники Скворцовой, существует опасность снижения качества здравоохранения при имеющемся недофинансировании тарифов $\mathrm{OMC}^{68}$. О факте недофинансирования ВМП правительством РФ свидетельствует пописанное Дмитрием Медведевым распоряжение от 10 мая 2016 года №865-p, согласно которому бюджетные ассигнования в размере 13 млрд. рублей направляются Минпромторгу России на предоставление субсидий государственной корпорации «Банк развития и внешнеэкономической деятельности» и государственному специализированному Российскому

${ }^{66}$ Полезный опыт турецкого здравоохранения. Ж.Ремедиум.,март 2012.,№3.,с.58.

${ }^{67}$ Ермак О. Принят закон об обязательном медицинском страховании.[Электронный ресурс].-Режим доступа:http://www.ruantalya. com/doska/166-sigortakural.html.Дата обращения 02.03.2013.

${ }^{68}$ Минздрав разделит высокотехнологичную помощь на «эксклюзивную» и «дорогостоящую».Первую будет оплачивать федеральный бюджет, вторую региональные бюджеты.01.03.13. [Электронный ресурс].-Режим доступа:http://www.univadis.ru/ medical_and_more /Local_Medical_News_Detail?link= /RU/ Local_ Medical_News /Minzdrav-razdelit-vysokotehnologichnuyu-pomosch-naeksklyuzivnuyu-i-dorogostoyaschuyu /(language)/ rus-RU\&id=964771. 
экспортно-импортному банку на возмещение части затрат, связанных с поддержкой производства высокотехнологичной продукции ${ }^{69}$. Реальный факт недофинансирования выявил аудит контрольно-счётной палаты (КСП) Волгоградской области. По данным полученным в результате проведенного аудита недофинансирование из областного бюджета высокотехнологичной медицинской помощи в 2012 году составило более 105 млн. рублей. Проверяющие КСП отметили, что получение некоторых видов медицинской помощи усложняется недостаточным количеством диагностического оборудования, предназначенного для бесплатного обследования. К примеру, существующая потребность в магнитно-резонансных томографах не обеспечена по области как минимум на 25\% (причем без учета количества исследований, проводимых в платных клиниках).На фоне снижения заболеваемости населения рост объема платных услуг, оказываемых в медицинских организациях частных форм собственности города Волгограда и области, значительно превышает рост объемов бесплатных услуг. Такая ситуация, по мнению КСП, способствует не только ухудшению качества оказываемой медицинской помощи и возникновению теневого оборота платной медицины, но также приводит к невозможности полноценного внедрения стандартов медицинской помощи ${ }^{70}$. В 2015 году на высокотехнологичную медицинскую

${ }^{69}$ На ВМП выделены 13 млрд. рублей. Remedium 16.05.2016. Документ подготовлен Минпромторгом в соответствии с пунктом 36 плана действий Правительства, направленных на обеспечение стабильного социально-экономического развития Российской Федерации в 2016 году (№1349п-П13 от 1 марта 2016 года).Электронный документ URL: http://www.univadis.ru/business-news/184/Na-VMPvydeleny-13-mlrd-rublej

703дравоохранение Волгоградской области нуждается в «интенсивной терапии». 24 апреля 2013. [Электронный ресурс].-Режим доступа: http://news.mail.ru/inregions/south/34/ society/12871800/?frommail=1 
помощь жители региона Волгограда должны были получить свыше 820 миллионов рублей. Как узнал Волгоград News в пресс-службе областной администрации, основная часть суммы направлялась из фонда обязательного медицинского страхования - порядка шестисот миллионов. Также не менее пятидесяти миллионов федеральная казна готова была выделить на операции для волгоградцев, которые не вошли в программу ОМС. К этой субсидии полагались средства из областного бюджета в размере 170 миллионов руб. По данным Волгоград News в 2015 году помощь высокого уровня была оказана 10,5 тысячам человек. В первую очередь жители города и области обращались к специалистам в сфере сердечно-сосудистой хирургии, офтальмологии, травматологии и ортопедии ${ }^{71}$.

Цифры не малые, но трудно анализируемые. В частности, по разделу сердечно-сосудистой хирургии. Количество пациентов нуждавшихся в данном и других разделах ВМП в регионе Волгограда публично не известно. Попытка найти реестр пациентов ЮФО или реестр пациентов Волгоградской области, нуждающихся в ВМП по сердечно-сосудистой патологии, не увенчалась успехом. Поиск включал сайты правительства области, областной администрации. Возможны возражения, что плохо искал. Этого нельзя сказать о реестре больных Сахарным диабетом. Простой набор в поисковой системе Яндекс «реестр больных сахарным диабетом Волгоградской области» сразу выдал результат вида: «Приказ Комитета по здравоохранению Администрации Волгоградской обл. от 17.12.2009 N 2748 “О работе территориальных регистров больных сахарным диабетом Волгоградской области“ (вместе с “Порядком ведения Государственного регистра лиц, страдающих сахарным диабетом“). Из этого можно

${ }^{71}$ Волгоградцам дадут денег на операции не по полису. http:// vnews34.ru/live/1932-volgogradtsam-dadut-deneg-na-operatsii-ne-popolisu.html./25.02.15. 
сделать вывод, реестра заболеваемости ишемической болезнью сердца нет. В документе Росздравнадзора анализирующего заболеваемость населения Волгоградской области болезнями системы кровообращения в2014 году использована компьютерная база данных ФБУЗ «Центр гигиены и эпидемиологии в Волгоградской области», составленная по материалам ГКУЗ ВОМИАЦ (ф. № 12 “Отчет о числе заболеваний, зарегистрированных у больных, проживающих в районе обслуживания лечебного учреждения”, данные по численности населения Волгоградской области).

По данным Росздравнадзора общая заболеваемость болезнями системы кровообращения в Волгоградской области составляла в 2014 году 21482,8 человек на 100 тыс. населения. Ведущими нозологическими формами общей заболеваемости населения Волгоградской области болезнями системы кровообращения были: а)болезни, характеризующиеся повышенным кровяным давлением (уровень заболеваемости в 2014г. составил 7720,4 на 100 тыс. населения); б)ишемическая болезнь сердца (5816,8 на 100 тыс. нас.), в)цереброваскулярные болезни (5483,1 на 100 тыс. нас. $)^{72}$

Обращал внимание уровень заболеваемости ишемической болезнью сердца и цереброваскулярными болезнями в Волгоградской области, который в 2014г был выше, чем в среднем по Российской Федерации в 2013г. (5074,6 и 4868,1 соответственно).А показатель заболеваемости болезнями, характеризующимися повышенным кровяным давлением за 5 лет увеличился на 6,0\%, ишемической болезнью сердца на 2,9\%.

Следовательно, вследствие 5 летнего роста заболеваемости ИБС и АГ в Волгоградской области, превышение

${ }^{72}$ Анализ заболеваемости населения волгоградской области болезнями системы кровообращения. Электронный ресурс: URL: http://34.rospotrebnadzor.ru/upload/iblock/339/143608\%20(1).pdf 
общероссийского уровня заболеваемости в 2014 года по ИБС и АГ потребность в ВМП по реваскуляризации миокарда в Волгоградской области, очевидно выше, чем в среднем по России.

Если сравнить статистические показатели Волгоградского региона ВМП по разделу сердечно-сосудистой хирургии с другими регионами, то они не радуют. В сравнительный анализ взяты данные 2014года опубликованные в Дальневосточном медицинском журнале ${ }^{73}$.

Таблица. Потребность в ВМП в разделе "Сердечно-сосудистая хирургия" по
регионам ДФО

Дапнневосточньй медпинский http://www.fesmu.ru/dmi/20144/2014424.aspx

Исходя из численности населения Дальнего Востока (6,265 млн. чел.), как указали авторы публикации, расчетная потребность в операциях при заболеваниях сердца и сосудов в округе Дальнего Востока составила более 17

${ }^{73}$ Першенкова Ю.Л., Сердюцкая О.А.,. Богачевская С.А,. Нетбай Р.В, Бондарь В.Ю. Результаты работы выездных бригад врачей в регионах дальневосточного федерального округ Дальневосточный медицинский журнал.2014..№4. Электронный ресурс: URL: http:// www.fesmu.ru/dmj/20144/2014424.aspx 
тысяч кардиохирургических операций в год. Всего в 2011 -2013 годах в Дальневосточном Федеральном центре сердечно-сосудистой хирургии была оказана высокотехнологичная кардиохирургическая помощь 13100 пациентам (77\% от 17 тыс.), что составило 25,7\% ежегодных расчётных потребностей в данном виде лечения. Численность населения Волгоградской области на 1 января 2016 года составляла 2545227 чел., что в 2.46 раза меньше чем в ДФО. Если расчётную потребность ДФО в 17 тысяч кардиохирургических операций в год уменьшить в 2,46 раза получится величина 7114.В то время как в Волгоградском регионе всех видов ВМП в 2015 году было оказано 10,5 тыс., а по разделу ВМП кардиохирургические операции, вероятно, в 3-4 раза меньше. Дополнительным аргументом в пользу недостаточной квотированности ВМП в регионе Волгограда является фактическое не выполнение рекомендаций BO3, согласно которым благополучной в вопросах охраны здоровья населения является ситуация, при которой на 1 миллион населения, страдающего болезнями системы кровообращения, выполняется не менее 6000 различных операций. При этом, по мнению ВОЗ, во всех странах мира существует потребность в повышении доступности наиболее эффективных и дорогостоящих видов медицинской помощи. Если применить данную рекомендацию к 2,545 млн. населению Волгоградской области, количество операций пациентов с заболеваниями системы кровообращения, исключая ВМП травматолого-ортопедического, репродуктивного, хирургического и офтальмологического профиля, должно составлять 12-15 тыс. операций в год. Существующая система оказания высокотехнологичной медицинской помощи больным ИБС, по мнению профильных специалистов челябинской области, осуществляет только учёт проведённых ВМП операций, в то время как необходим анализ спроса на данный вид ВМП и оценка 
результативности данного вида услуг ${ }^{74}$ В тоже время в оценке результативности ВМП по разделу реваскулиризации миокарда важна послеоперационная лекарственная поддержка больных.

В федеральном бюджете и бюджете федерального фонда ОМС нет выделенной статьи расходов на пилотный проект по обеспечению лекарствами больных после сосудистых операций. Минздрав не нашел источников финансирования «пилота» стоимостью 2,4 млрд.руб. даже после прямого поручения президента министру здравоохранения Веронике Скворцовой ${ }^{75}$

В арсенале аптек для пациентов после планового стентирования есть как относительно дорогие, так и относительно недорогие препараты - дженерики. Принимать их, помимо других обязательных препаратов, включая антиагреганты и антикоагулянты, нужно обычно менее года. О выделении средств на лекарства в марте 2016 года с президентом говорила лично глава Минздрава Вероника Скворцова. Из расчетов Минздрава следует, что на лекарства одному больному требуется чуть менее 40 тыс. руб. в год, всего 4,7 млрд. руб. на лечение 120 тыс. прооперированных. На вопрос «Газеты.Ru», будут ли в результате выделены средства с 2017 года или пилотный проект так и не заработает, в Минздраве не ответили. Единственный на сегодня проработанный «пилот» относится к компенсации лекарств для «сердечников». Проект заявлен как уже разработанный

${ }^{74}$ Белова С.А., Москвичева М.Г., Лукин О.П., Белов Д.В. Анализ заболеваемости и уровня доступности высокотехнологичной медицинской помощи больным ишемической болезнью сердца в челябинской области// Современные проблемы науки и образования. - 2014. - № 2.; URL: http://www.science-education.ru/ ru/article/ view?id=12470 (дата обращения: 16.11.2016.

${ }^{75}$ Малышева Е. «Пилот» пролетит мимо сердца. Минздрав не нашел денег на поручение Путина о бесплатных лекарствах сердечникам. [Электронный ресурс].-Режим доступа: https://www.gazeta. ru/business/2016/11/17/10340069.shtml 
и должен начаться с 1 января 2017 года повсеместно, на всей территории России. Но при этом реального источника финансирования так и не нашлось-сообщила корреспонденту «Газеты.Ru» директор Института экономики здравоохранения НИУ ВШЭ Лариса Попович. То, что в бюджете нет специально выделенной статьи под это финансирование, серьезная проблема, подтверждают эксперты. Это означает, что полностью готовый проект «однозначно не состоится».

В общей практике пациенты в амбулаторном режиме получают лекарства бесплатно только по льготам, хотя лекарства, перечисленные в стандартах медицинской помощи, тоже должны быть бесплатными. «Но стандарт сейчас игнорируется», - считает президент Лиги защиты пациентов Александр Саверский. «Именно поэтому практика правоприменения не позволяет компенсировать стоимость лекарств стентированным больным, если финансирование не маркировано особой нормой закона. Более того, оно может быть признано нецелевым использованием денег».

В 2012 году вследствие недофинансирования регионов, в которых были медучреждения, оказывавшие высокотехнологичную медицинскую помощь, 59 субъектов получили субсидии или были вынуждены дополнительно выделить собственные средства. Существенно то, что не все регионы России, оказывающие ВМП, получили дополнительные субсидии по линии участия в программе. В2012 году в программе участвовало 59 субъекта РФ из 83.В2013 году в программе приняли участие 62 субъекта РФ. Премьер-министр РФ Дмитрий Медведев на встрече с заместителями в ноябре 2016 года заявил, что в текущем 2016 году увеличены объемы оказания высокотехнологической медицинской помощи почти на 10\%.По озвученным на встрече данным в 2015 году ВМП получили 823 тыс. человек, тогда как за 2016 год показатель будет увеличен еще на 100 тыс. Было отмечено, что несмотря на ежегодное увеличение охвата населения ВМП сохраняется проблема её доступности. «Нужно и дальше совершенствовать 
механизмы предоставления высокотехнологичных видов лечения, потому что это самое сложное, дорогостоящее лечение. Нужно сделать все, чтобы оно было для граждан нашей страны более доступным», - поставил задачу премьер министр Дмитрий Медведев ${ }^{76 .}$

Как показал опыт республики КОМИ ${ }^{77}$ 5-летние расхождения между фактическими, плановыми и расчетными показателями в динамике оказания медпомощи в системе OMC нарастают, что свидетельствует о всё меньшем соответствии фактических расходов финансовым планам и финансовым расчетам. На заседании правительства РФ 28 февраля 2013 года министр здравоохранения РФ Вероника Скворцова в своем докладе сообщила, что финансовое наполнение ОМС за 2013-2014 годы должно увеличиться, поэтому в 2015 году большая часть высокотехнологичной помощи, которая, по сути, является дорогостоящей специализированной медпомощью, будет погружена в $\mathrm{OMC}^{78}$. Пяти летний опыт расхождений между фактическими, плановыми и расчетными показателями медпомощи в системе ОМС республики КОМИ, повсеместное недофинансирование

${ }^{76} \mathrm{~B} 2016$ году ВМП получат 900 тысяч россиян. [Электронный ресурс]. - Режимдоступа: http://www.univadis.ru/ business-news/184/V-2016-godu-VMP-poluchat-900-tysyachrossiyan?utm_source=newsletter+email\&utm_medium $=$ email \&utm campaign =medical+updates+-+daily\&utm_content $=1144627 \& u_{\text {tm }}$ term=automated_daily.14.11.16

${ }^{77}$ Светличная Т.Г..ЦыгановаО.А.,Борчанинова Е.Л. Состояние финансирования системы ОМС республики Коми.Ж.Экономика здравоохранения.-2010.-№9-10.-с.43-54.

${ }^{78}$ Минздрав разделит высокотехнологичную помощь на «эксклюзивную» и « дорогостоящую».Первую будет оплачивать федеральный бюджет, вторую региональные бюджеты.01.03.13. [Электронный ресурс].-Режим доступа:http://www.univadis.ru/ medical_and_more/Local_Medical_News_Detail?link= /RU/ Local_ Medical_News /Minzdrav-razdelit-vysokotehnologichnuyu-pomosch-naeksklyuzivnuyu-i-dorogostoyaschuyu /(language)/ rus-RU\&id=964771. 
тарифов ОМС в регионах, включая Волгоградский, свидетельствуют о недостаточной доступности дорогостоящей ВМП из финансируемых ОМС средств на местах.

O качестве составления прогнозируемых финансовых планов и механизме их просчетов в системе ОМС можно судить на основании статей Ф3 №326 «Об обязательном медицинском страховании» в редакции 2010 года. Финансовой особенностью Ф3-326 являлась отсроченная с 1 января 2012 года реализация ст.14 п.6 механизма обеспечения финансирования на федеральном и территориальном уровнях программы государственных гарантий за счет средств целевого финансирования поступающих в страховые медицинские организации. Как справедливо указали критики, через весь законопроект проходит требование обязательности исполнения медицинскими организациями и медработниками порядков и стандартов оказания медпомощи утвержденных на Федеральном уровне (статья 38), без достаточно гарантированной их финансовой поддержки ${ }^{79}$, то есть в условиях фактического недофинансирования.

Помимо финансовых проблем оплаты федеральных стандартов в практическом здравоохранении также выделяют: не разграниченность регионарных стандартов по уровням оказания и финансового обеспечения ВМП, сопротивление изменениям, консервативность медицинской практики ${ }^{80}$. Деньги под исполнение данных

${ }^{79}$ Александров О.Ю., Кременков А.Р. Законопроект «Об основах охраны здоровья граждан в Российской Федерации»: новеллы правового регулирования, положительные и отрицательные аспекты законопроекта. /Ж.Менеджер здравоохранения.№12.,2010. С.14-31.

${ }^{80}$ Обухова О.В. Проблемы внедрения медико-экономических стандартов в учреждения, оказывающие стационарную медицинскую помощь./Обухова О.В., Базарова И.Н.,Гавриленко О.Ю.// Социальные аспекты здоровья населения. Информационно-аналитический вестник.-2008.-№3(7)// [Электронный ресурс].-Режим доступа:http://vestnik.mednet.ru. 
обязательств формируются за счет: субвенций из бюджета Федерального фонда бюджетам территориальных фондов обязательного медицинского страхования (ТФОМС), федеральной компенсации выпадающих доходов в связи с установлением пониженных тарифов страховых взносов, доходов от размещения временно свободных средств, недоимок по взносам и налоговым платежам, начисленных пеней и штрафов и иных источников (Ст.21 Ф3-326). В качестве перспективы развития системы ОМС в обществе обсуждается введение института страховых представителей в системе $\mathrm{OMC}^{81}$. Однако их эффективность с точки зрения повышения уровня предоставляемых медицинских услуг респонденты оценивают с осторожностью: $50 \%$ считают, что это решение не повлияет на качество предоставляемой в рамках ОМС медпомощи. Те, кто считают, что ситуация изменится, скорее ожидают позитивных перемен (34\%), нежели негативных (2\%).

При этом отсутствует эффективный надзор и контроль за антикризисной деятельностью СМО и вверенными им финансовыми ресурсами. Существующая система надзора, основанная на анализе сложившейся системы финансовой отчетности, ограничена недостатками ориентации на констатацию, а не на упреждение фактов финансовых затруднений у страховых компаний. Она позволяет лишь выявлять проблемы постфактум, когда уже имеется серьезное ухудшение финансового состояния медицинской страховой компании. В России система антикризисного регулирования страховой деятельности в самом общем виде сформирована, однако некоторые элементы только вводились или находились в стадии проекта к концу 2012 года. В целом говорить об антикризисном регулировании

${ }^{81}$ Эксперты внесли предложения по развитию системы OMC. Фармацевтический вестник. 07.09.2016 http://www.pharmvestnik.ru/ publs/lenta/v-rossii/eksperty-vnesli-predlozhenija-po-razvitiju-sistemyoms.html\#.V9LcmSOhqkq 
страховой отрасли как о системе в 2012 году было рано ${ }^{82}$. Лишь в последующие годы в системе ТФ ОМС были сформированы фонды нормированного страхового запаса для покрытия выплат по обязательствам обанкротившихся страховых медицинских организаций, которые в среднем носили недостаточный компенсационный характер.

По Ф3-326 медицинская организация не вправе отказать застрахованным лицам в оказании медицинской помощи в соответствии с территориальной программой обязательного медицинского страхования (ст.15,П.5). При этом в ст.15 п.4. Ф3-326 прямо указано, что медицинская страховые организации в течение года имеют права не осуществлять деятельность в сфере обязательного медицинского страхования в случаях ликвидации медицинской организации, утраты права на осуществление деятельности, банкротства или иных предусмотренных законодательством РФ случаев. Несмотря на это, в апреле 2010 года в рамках изменений к Федеральному закону от 27.11.1992 г. №4015-1 «Об организации страхового дела в Российской Федерации» было зафиксировано увеличение требования к минимальному уставному капиталу страховщиков с 01.01.2012 г. с 30 млн. рублей до 120 млн. рублей. Для страховщиков, осуществляющих исключительно медицинское страхование, минимальный размер уставного капитала не увеличился и был оставлена прежнем уровне в тридцать миллионов рублей.

По мнению аналитиков ${ }^{83}$, законодательные меры по увеличению размера уставного капитала страховщиков

${ }^{82}$ Насырова Г.А. Управление риском в системе антикризисного регулирования страховой отрасли. Ж.Эффективное антикризисное управление.2012.№1.

${ }^{83}$ Колесников Ю. А. Финансовая устойчивость страховщиков в фокусе законодательных инициатив // Страхование сегодня: [Электронный ресурс].5 октября 2010. Режим доступа: http://www.insurinfo.ru/analysis/667 
можно рассматривать как своеобразную форму компенсации того, что на сегодняшний день страховой надзор работает в несколько ретроспективном режиме, принимая те или иные решения в отношении страховщиков на основании анализа предоставляемой ими отчетности за прошедшие периоды времени. В этой связи, не имея пока возможности работать в режиме онлайн, надзор обладает ограниченным спектром инструментов для предупреждения проблемных моментов, связанных с недостаточной финансовой устойчивостью и платежеспособностью страховщиков. Поэтому повышение требований к минимальному размеру уставного капитала - рассматривалось как действенная форма защиты сложившейся системы страхования в целом, поскольку больший размер уставного капитала подразумевает наличие большего объема средств, которые могут быть направлены на закрытие кассовых разрывов в случае возникновения проблем с платежеспособностью страховой компании. В тоже время в отношении страховых медицинских организаций данная законодательная мера оказалось, по неясным причинам, не актуальной.

Что практически это означает? То, что в случае банкротства СMO, право застрахованных граждан на получение гарантированной бесплатной медпомощи, в первую очередь дорогостоящей ВМП, по ФЗ 326 может оказаться ущемленным пределами 30 млн.рублей уставного капитала территориального фонда ОМС. Для отдельных категорий населения подобные «временные» финансовые затруднения территориального фонда ОМС могут быть критичными для защиты жизни и охраны здоровья, гарантированных конституцией РФ.

В настоящее время проводится оптимизация страхового надзора путем попыток создания мега регулятора. Эволюция финансовых институтов привела к исчезновению существенных различий между финансовыми секторами - банковским, инвестиционным и страховым. Под 
влиянием процессов интеграции и конвергенции происходят унификация государственного регулирования деятельности институтов финансового рынка и формирование системы мега регулирования. Это объясняется также довольно тесной взаимосвязью финансовых институтов и проявлением высокого риска вероятности негативного влияния со стороны аффилированных структур. Однако здесь также существуют проблемы, связанные с различиями в организации учета, отчетности в финансовых институтах. Согласно Федеральному закону «О консолидированной финансовой отчетности», с 2012 г. все публичные компании должны представлять отчетность в соответствии с международными стандартами финансовой отчётности-МСФО. Ожидается, что страховые компании начнут выполнять это условие с 2015 года ${ }^{84}$, за исключением Росгосстраха, который планировал это сделать раньше.

В группу компаний Росгосстрах входят ОАО Росгосстрах, ООО Росгосстрах, СК РГС-Жизнь, занимающаяся страхованием жизни и добровольным пенсионным обеспечением, а также ООО РГС-Медицина, осуществляющая операции по обязательному медицинскому страхованию. ООО Росгосстрах - это 83 филиала во всех субъектах РФ, включающих около трех тысяч агентств, страховых отделов, офисов продаж, подразделений урегулирования убытков. Президент компании и основной владелец Росгосстраха Данил Хачатуров заявлял, что Росгосстрах рассматривает возможность проведения IPO ( Initial Public Offering) не ранее 2013 года ${ }^{85}$.

${ }^{84}$ Колесников Ю. А. Финансовая устойчивость страховщиков в фокусе законодательных инициатив // Страхование сегодня: [Электронный ресурс].5 октября 2010. Режим доступа:http://www.insurinfo.ru/analysis/667

${ }^{85}$ Росгосстрах начинает активную подготовку к проведению IPO. Интернет ресурс http://korrespondent.net/rynki/stockmarket/1231028odna-iz-krupnejshih-strahovyh-grupp-rf-gotovitsya-k-ipo 
Необходимость внедрения международной финансовой отчётности-МСФО вызвана тем, что пока ни одну российскую страховую медицинскую компанию нельзя назвать публичной, поскольку ни одна из них не провела IPO.

Как указывают эксперты, пройдя процесс IPO компания включается в котировальные списки в выбранных фондовых биржах, на которых она размещается. То есть акции получают котировки, которые появляются в процессе совершенных сделок с бумагами этой компании. Есть предложение и спрос (bid и ask) - они формируют котировки при наличии сделок. Зная общее количество выпущенных акций компании, в рамках данной эмиссии, умножив их на котировку можно посчитать капитализацию компании, то есть узнать, сколько компания реально стоит.

Хотя термин IPO может охватывать первичное размещение или обращение любых эмиссионных ценных бумаг (акций, облигаций, паев и депозитарных расписок),в отношении СМО термин IPO применяется преимущественно к акциям, что предполагает оценивание эффективности размещения и финансового управления ими.

Среди российских страховых компаний ближе всего в 2008г подошли к IPO «Ингосстрах» и РОСНО. Обе компании капитализировались, и активно наращивали обороты деятельности, в том числе за счет слияний и поглощений. Среди перестраховщиков о своих планах разместиться на бирже заявила только «Москва Ре» - наиболее прозрачный на тот период времени российский перестраховщик. В 2014 году об этом же заявила государственная страховая компания «Югория», которая предприняла очень нетипичный для провинциальной компании шаг выход на IPO как один из путей спасения более чем проблемного актива компании. Эксперты отнеслись к этому шагу страховой компании критически. По их мнению, 
привлечь иностранных инвесторов, да еще в компанию, которая работает с ОСАГО, практически не реально ${ }^{86}$.

Для проведения IPO на западном рынке необходимы некоторые условия:

- отчетность по международным стандартам

- сотрудничество с международным аудитором («большая четверка»)

- раскрытие информации о владельцах

При этом аудированную отчетность нужно иметь за несколько лет. Не у всех страховщиков такая отчётность имеется. Раскрыть информацию о конечных бенефициарах не составляет особой сложности. Остаётся привлечь инвесторов. И здесь в дело вступают другие факторы, в том числе экономические-санкции Евросоюза, ограничивающие западные инвестиции в российские компании, в том числе страховые.

Существующие недостатки антикризисного и финансового управления страховыми компаниями в России усугубились прекращением с 01 января 2013 года федерального финансирования оплаты медуслуг, оказываемых скорой медицинской помощью и оплата их, как и ВМП, из дефицитных средств территориального фонда ОМС. Федеральные надбавки за оказанную помощь врачебно-фельдшерскому персоналу также передали в территориальные фонды ОМС. При этом часть счетов СМП (сейчас это 5-10\%) штрафуется и не оплачивается СМО. На этом фоне в 2013 году в Московской области разгорелся скандал вокруг подразделений Службы скорой помощи. Врачи «неотложки» города Одинцово написали коллективное обращение к президенту России Владимиру Путину и в Следственный комитет Подмосковья с просьбой разобраться, куда тратятся деньги, выделенные на доплаты медперсоналу, а

${ }^{86}$ Источник: http://fedpress.ru/news/banks/insurance/1413381963yugorskuyu-strakhovuyu-kompaniyu-sobralis-spasat-cherezipo/16.10.2014. 
также пожаловались на невыносимые условия работы, которые в первую очередь отражаются на качестве обслуживания пациентов. Так, некоторые бригады скорой помощи состоят всего из одного человека, а врачи и фельдшеры не получают положенные им добавки ${ }^{87}$.

Неполная оплата СMO услуг СМП и ЛПУ препятствует адекватному финансовому покрытию оказываемых скорой медпомощью услуг и финансово не обеспечивает покрытия стандартов ВМП из фондов ОМС. Успешному решению проблемы оказания всем нуждающимся дорогостоящей ВМП препятствует отсутствие стабильного роста финансовых поступлений в фонды CMO.

Дефицит финансового обеспечения территориальных программ привел к тому, что увеличение доли расходов на оплату труда, коммунальные расходы и содержание имущества учреждений здравоохранения, подлежащих ежегодной индексации, осуществляются за счет сокращения расходов на медикаменты и другие материальные запасы. И как результат - снижение уровня медикаментозного (лабораторно-диагностического) сопровождения медицинской помощи и ресурсного обеспечения стандартов медпомощи. С другой стороны, рост расходов на ВМП не покрывает «приносящая доход деятельность» страховых медорганизаций, штрафующих ЛПУ и СМП по любому поводу.

В остальных случаях страховое обеспечение в соответствии с базовой программой обязательного медицинского страхования устанавливается исходя из стандартов медицинской помощи и порядков оказания медицинской помощи, установленных уполномоченным федеральным органом исполнительной власти. Это означает, что страховые выплаты должны быть такими, чтобы гарантировать оплату медпомощи, оказанную в соответствии со стандартом медпомощи.

${ }^{87}$ Одинцовская скорая просит помощи у президента. Евстифеев Д, Гладченко Н. Газета Известия. 22052013 №90 (28844). С.5. 
Требование необходимости соблюдения стандарта медпомощи врачом(объективно возможны разные клинические ситуации) жесткое требование субъекта оплачивающего эту медпомощь а, именно страховой медицинской организации сотрудничающей с ТФОМС. Иначе оказание медпомощи СМО не оплачивает и медучреждение штрафуется. При этом врач должен исходить из оплаты конкретной клинической ситуации, соответствующей стандарту медпомощи, которую логичнее было бы оплачивать как вид услуги. В случае оказания не вписывающейся в рекомендуемый стандарт медпомощи она либо частично оплачивается, либо не оплачивается вообще по решению СМО. Вследствие этого медпомощь нужно выполнять строго в рамках стандарта. В тоже время врач несет уголовную ответственность по ст. 109 УК РФ п.2 за причинение смерти по неосторожности в связи с ненадлежащим оказанием медпомощи, в том числе по стандарту. На лицо противоречие между неадекватным финансовым покрытием оказываемой медпомощи со стороны СМО, по субъективным причинам, и её объективными законодательно-правыми последствиями для врачебных кадров по статьям КОАП и УК РФ.

С финансовой стороны на период 2013-2015гг фонд OMC планировала перечислять деньги за услуги СМП из расчета 1435,6 руб. за 1 вызов. Проблема оплаты в том, что последняя планируется из норматива1 вызов на 1 жителя. В то время как в реальной практике норматив не выше 0,318 вызова на 1 жителя. Это означает невозможность в принципе достижения норматива ОМС и запланированные финансовые потери, так как все что ниже норматива одного вызова на 1 жителя СМО не оплачивает. Сточки зрения «приносящей доход деятельности» оценка качества медпомощи по нормативу меньше 1выгодна лишь СМО. За невыполнение норматива, помимо неоплаты вызова, со стороны CMO предусмотрены штрафы к предприятиям 
СМП. Как и за что страховщики умеют штрафовать -«притча во языцах». Для экономии средств в ТФОМС созданы и функционируют целые отделы проверяющих карты вызовов СМП и истории болезни в ЛПУ.

Перевод служб СМП на оплату из ОМС неизбежно был связан с ухудшением её финансирования. Для службы СМП это означало только одно: не все медицинские услуги оплачиваются. В лучшем случае - почти все. В худшем далеко не все. «Нехватку денег» многие ЛПУ восполнили за счет внедрения платных услуг в ассортимент деятельности и переход на частичную самоокупаемость. В связи с этим неизбежно возникло ограничение услуг оказания бесплатной медпомощи.

Развернувшаяся в стране борьба с коррупцией не способствовала улучшению финансового обеспечения СМП, ЛПУ и внедрению в работу патентных инновационных медтехнологий. Согласно данным Следственного комитета РФ, здравоохранение вошло в тройку самых коррумпированных сфер и занимает «почётное» второе место по уровню коррупции после правоохранительной системы. Силовые структуры государственной власти информируют общественность об успехах в борьбе с коррупцией, придавая этому направлению деятельности статус государственной важности. Совершенно очевидно, что все больше врачей, оказывающих амбулаторно-поликлиническую, стационарную и неотложную медпомощь, в таких условиях будут избегать любой инициативы при оказании медпомощи сверх стандартов лечения и обследования. При этом врачи уже сегодня вынуждены ограничивать «избыточное» общение с пациентом, ибо количество возбуждаемых дел по медицинской тематике быстро растёт благодаря умелым действиям СК и прокуратуры РФ. Нередко, акцент следствия при этом смещен в сторону раскрытия легко доказуемых дел. «Подсадной утке» прокуратура выдает меченые денежные купюры и отправляет 
на прием к врачу, потом берут врача с «поличным», так как имеются показания «потерпевшего».

Как отмечают средства массовой информации,ФЗ-326 работает по стандартам оказания медпомощи, которые должны быть везде одинаковыми. Предполагается что эффект от лечения, не считая индивидуальных особенностей течения заболеваний и особенностей развития осложнений, должен быть везде одинаково эффективным. При этом информации, особо развивающей и адаптирующей новые стандарты лечения,ФЗ-326 не даёт.

Необходимость введения СМО нормативов оценки качества оказания скорой медицинской и амбулаторной медпомощи лишнее свидетельство недостаточной продуманности принятого Ф3-326. Она и в некорректности нормативов оценки качества медпомощи со стороны СМО. И в предложении ГД правительству РФ подготовить поправки в КОАП, законодательно разрешающие региональным органам надзора и контроля в сфере здравоохранения возбуждать и рассматривать дела за нарушение законодательства и невыполнение стандартов медпомощи. Минздраву рекомендовалось разработать порядок проведения экспертиз качества медицинской помощи, оказываемой вне системы обязательного медицинского страхования, введение административной ответственности для медицинских организаций, чья работа не соответствует установленным Минздравом стандартам оказания медпомощи, в том числе по объективным причинам.

К типично объективным причинам несоответствия оказываемой медицинской помощи стандартам относится отсутствие оборудования и специалистов ${ }^{88}$. При этом готовность российских муниципальных субъектов к обязательному исполнению с 1 января 2013 года утвержденных

${ }^{88}$ В Волгоградской области медпомощь не соответствует установленным в России стандартам.[Электронный ресурс].-Режим доступа:htpp://v102.ru/news/37181.html.06.12.2012.(Обновлено:07.12.2012). 
Минздравом РФ требований, по оказанию медицинской помощи и стандартов медпомощи, во многих российских регионах оставляла желать лучшего. По данным Росздравнадзора ${ }^{89}$, максимальное соответствие порядкам оказания медпомощи было отмечено в медицинских организациях, вошедших в специальные программы. В других медицинских организациях в наибольшей степени требованиям отвечали лишь отдельные профили: акушерство, травматология, анестезиология и реаниматология. Так обстояли дела в Северной Осетии, Пермском и Приморском краях, Амурской, Орловской, Иркутской, Сахалинской, Волгоградской областях. По мнению авторитетных российских практиков и специалистов, в Ф3-326 нормативные затраты ТФОМС основанные на федеральных стандартах Минздрава, не учитывали и не учитывают вероятность дополнительных расходов, обусловленных возрастом, сопутствующей патологией, осложнениями, а также сложившуюся структуру госпитализаций, изменений технологий диагностики и лечения больных ${ }^{90}$. Законодательно тупиковой представляется ситуация с региональными стандартами оказания медицинской помощи, которые с начала 2013 года перестали действовать, но продолжают использоваться СМО, в отсутствие разработанных федеральных стандартов.

Необходимо отметить, что субъекты РФ действительно могли разрабатывать и утверждать стандарты медицинской помощи до 2012 года. Точнее до 1 января 2013 года, до ввода в действие заключительных положений ч.1 ст. 100 Ф3-323. В п.11 заключительных положений указано,

${ }^{89}$ В Волгоградской области медпомощь не соответствует установленным в России стандартам.[Электронный ресурс].-Режим доступа: htpp://v102.ru/news/37181.html.06.12.2012.(Обновлено:07.12.2012).

${ }^{90}$ Бокерия Л.А. Роль информационных систем в сопоставлении стандартов с реальной клинической практикой (на примере «Стандарта медицинской помощи больным со стабильной стенокардией»)/Бокерия Л.А. Ступаков И.Н. Самородская И.В. Фуфаев Е.Н. // Здравоохранение для главврачей и бухгалтеров.-2007.-№11.-С.23-30. 
что до 1 января 2013 года медицинскими организациями могут применяться порядки оказания медицинской помощи и стандарты медицинской помощи, утвержденные уполномоченным федеральным органом исполнительной власти в соответствии с настоящим Федеральным законом, в том числе в рамках реализации региональных программ модернизации здравоохранения субъектов Российской Федерации ${ }^{91}$.

Таким образом, в 2016 году региональные стандарты оказания медицинской помощи уже не являются действующими. Однако при проведении экспертизы, в отсутствие медицинских стандартов, принятых и утверждённых приказом Минздрава РФ после 2012 года СМО говорят о необходимости исполнения других стандартов оказания медицинской помощи. В таких случаях речь идёт о стандартах оказания медпомощи, принятых региональным министерством здравоохранения с 2008 года. При этом при невыполнении региональных стандартов СМО проводят неполные выплаты по страховым случаям или назначают штрафные санкции, что является не правомерным ${ }^{92}$ и противоречит заключительным положениям Ф3-323 «Об охране здоровья».

В зарубежной практике, если стандарт разрабатывается вне системы управления качеством, то он просто высту-

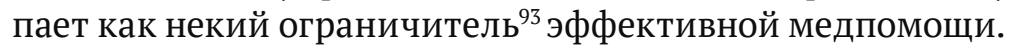

${ }^{91}$ Федеральный закон «Об основах охраны здоровья граждан в Российской Федерации»(с изменениями на 3 июля 2016 года). URL pecурс: http://docs.cntd.ru/document/902312609.

${ }_{92}$ Строгое следование стандартам медпомощи: как избежать штрафов от CMO.URL pecypc:http://www.zdrav.ru/articles/4293650283qqq-16-m7-25-07-2016-strogoe-sledovanie-standartam-meditsinskoypomoshchi-izbejat? utm_source=letternews\&utm medium=letter\&utm campaign= letter news_zdrav_zdr_01082016_daily_readers_30632.

${ }^{93}$ FisherW.H.,Simon L,Geller J.L,Penk W.E. et al. Case mix in the “downsizing” state hospital. Psychiatr.Serv.1996;47:255-262. 
Фактически в Ф3-323 не была изначально прописана система управления качеством оказания медпомощи. Данный недостаток ГД РФ планировала исправить постановлениями правительства РФ в виде поправок в КОАП, устанавливающих полномочия региональных органов по контролю и надзору в сфере здравоохранения возбуждать и рассматривать дела об указанных административных правонарушениях. При этом Ф3-326 «Об обязательном медицинском страховании в $Р \Phi^{94}$ » изначально защищал коммерческие интересы СМО и позволял СМО не осуществлять полных выплат по страховым случаям, неправомерно штрафовать ЛПУ как источник наиболее быстрого дохода приносящей деятельности. В п.4,5 статьи 31Ф3-323 говорится ${ }^{95}$, что страховая медицинская организация вправе предъявить лицу, причинившему вред здоровью застрахованного лица, требование о возмещении своих расходов на проведение дополнительной экспертизы по установлению данного факта, оформлению необходимой документации, а также о возмещении судебных издержек. Однако факт ненадлежащего оказания медпомощи необходимо обосновать в судебном порядке. Юридическое обоснование для страхуемых в судах обременительно финансово и достаточно затратно по времени. Исполнение решений по судебно обоснованным искам, как правило, отсрочено во времени из-за отсутствия свободных финансовых средств у СМП и ЛПУ для выплат по судебным решениям. Очевидно, что здесь у СМО значительные преимущества перед физическими лицами, ведь для исполнения штрафов к ЛПУ по результатам проверок СМО не требуется решений суда.

${ }^{94}$ Федеральный закон «Об основах охраны здоровья граждан в $P \Phi »$. https://normativ.kontur.ru/document?moduleId=1\&document Id $=263251$.

${ }^{95}$ Об обязательном медицинском страховании. Федеральный закон №326-Ф3.Москва. Проспект.2011.,64с. 
Решение проблемы страхования профессиональной ответственности медицинских работников с учетом действующего разграничения полномочий между уровнями власти находится в стадии разработки. Порядок и размер указанного страхования может быть определен государственными органами власти достаточно усреднено и только для подведомственных учреждений. В этой связи неизбежна дефицитность страховых выплат и имущественная ответственность врачебного персонала бюджетной организации перед потребителями медицинских услуг при нерешенном в целом вопросе страхования профессиональной ответственности в системе здравоохранения. При этом главная проблема заключается в том, где взять деньги для покрытия судебных издержек и юридических исков.

По Ф3-326 вопрос ненадлежащего исполнения медицинской организацией обязанностей по усмотрению специальных комиссий и на основании поправок в КОАП со стороны медицинских организаций и потребителей медуслуг загружает суды потоком кассационных жалоб, которые и без этого не справляются со своей работой. В связи с тем, что суды перегружены подобного рода делами, глава Высшего арбитражного суда Антон Иванов неоднократно высказывался за повышение госпошлин. В итоге Госдума в конце декабря 2011 приняла поправки к Налоговому кодексу, существенно увеличивающие денежные сборы с физических и юридических лиц, которые вступают во взаимоотношения с госорганами ${ }^{96}$. Речь идет о новой редакции статей 333.19-333.40 налогового кодекса, устанавливающих размеры пошлин, средний размер которых увеличен в два раза. К примеру, минимальная пошлина, которую нужно заплатить при подаче имущественного

\footnotetext{
${ }_{96}^{96}$ Буранов.И. Государство увеличивает сборы за услуги. Деловая on-line газета «Бизнес партнер».03.01.2012.[Электронный ресурc].-Режим доступа: http://bizprt.ru/?id=7722\#10
} 
иска в суд общей юрисдикции, увеличена в два раза, в арбитражный суд - в четыре раза. Таким образом, судебные инстанции с помощью увеличения пошлин отсеивают многие «мелкие» дела, не решая при этом возникающих проблем. При этом в ведомстве признают, что «любое решение, связанное с дополнительным обременением для граждан, является непопулярным».

Недостаточно исправляет ситуацию ПП РФ №1006 от 04.10.12г «Об утверждении правил предоставления медицинскими организациями платных медицинских услуг». Согласно данного ПП с 1 января 2013 года контроль за исполнением оказания платных услуг осуществляют территориальные представительства Роспотребнадзора. В данный орган следует обращаться, если платная услуга оказана не должным образом. При этом Роспотребнадзор уполномочен проводить проверки, выносить предписания об устранении недостатков при оказании платных медуслуг и налагать штрафы:на юридическое лицо-от 20 до 30 тыс. руб.,на частного предпринимателя-от 10 до 20 тыс.руб. За возмещением ущерба или морального вреда гражданину надлежит обращаться в суд. Постановление суда создаёт юридическое обоснование материальной компенсации в судебном порядке за некачественно оказанные медуслуги для граждан, но вряд ли улучшает их обслуживание. При этом эксперты разошлись в оценках нововведений. Одни эксперты отметили, что в документе имеется множество лазеек для недобросовестных исполнителей. Другие выделили, что данный закон превращает профессию врача в работу с калькулятором и циркулярами, и это несмотря на то, что современный врач давно обременён множеством несвойственных ему административных и бухгалтерских функций ${ }^{97}$.

${ }^{97}$ Бокк А. Стоимость здоровья. За какие медуслуги придётся платить? Газета АИФ. Дата публикации 12.10.12г. [Электронный peсурс].-Режим доступа: http://www.aif.ru/ health/ article/56049. 
В числе прочих ПП №1006 не решило вопроса противоречий между необходимостью внедрения инновационных видов медицинской помощи и их интерпретаций как не прописанных и не входящих в стандарт лечения. Кто может взять на себя риск последствий внедрения инновационных видов медицинской помощи, выходящих за рамки утвержденных стандартов медпомощи? Венчурные предприятия?

Достоинства платной медицины - это лучшие медицинские кадры, современные методы исследования, передовое оборудование, хорошая техническая база, эффективные современные методы управления. Среди минусов - зачастую высокие расценки на услуги, дополнительная оплата повторных визитов при продолжительном лечении, недобросовестность врачей в установления диагноза с увеличением сроков лечения и выплат за недостаточно качественное лечение. На самом деле один из наиболее эффективных современных методов управления - это методология управления качеством, когда повышение качества медпомощи возможно без увеличения затрат, а иногда даже с их уменьшением за счёт более эффективного использования имеющихся ресурсов и уменьшения дополнительных необоснованных расходов. В Тульской области ${ }^{98}$ внедрение системы управления качеством позволило получить следующие результаты. Число пациентов с АГ, получающих лечение на первичном этапе оказания помощи увеличилось в 7,6 раз. Нормализация уровня кровяного давления достигнута у $69,4 \%$ пациентов. Число случаев госпитализации по причине АГ среди наблюдаемых пациентов снизилось

${ }^{98}$ Совершенствование методов управления и организационных структур. /Методические рекомендации по развитию здравоохранением: совершенствование управления здравоохранением, организация общей врачебной практики,укрепление здоровья и профилактика неинфекционных заболеваний. Москва,2003.46 С. 
на $85 \%$, а число случаев гипертонических кризов на $60 \%$. Для мониторинга состояния качества медпомощи чаще других используются показатели оценки приоритетных направлений реформы здравоохранения, а именно \% выполнения установленных стандартов лечения; отношение числа повторных (в течение) 1 месяца госпитализаций к общему числу госпитализаций. К сожалению таковых сведений в системе управлении качеством Тульской области не оказалось.

Принятый 1 декабря 2007 года ФЗ № 315 «О саморегулируемых организациях» (СРО), имеющий прямое отношение к перспективным и доказавшим свою эффективность в зарубежных странах механизмам повышения качества медицинской помощи и государственно-частного партнерства, в отношении медицинских организаций РФ эффективно не работает. Несмотря на то, что ФЗ №315 направлен на проведение единой государственной политики в области разработки и принятия стандартов в государственно-частном секторе, среди практиков и ученых в российском здравоохранении закон в этой части не нашел широкой поддержки. В части 3 ст. 4.ФЗ № 315 отмечено, что «стандарты и правила саморегулируемых организаций должны соответствовать федеральным законам и принятым в соответствии с ними иным нормативным правовым актам».

Так как по многим видам медицинской помощи государственные стандарты не были разработаны, закон не обязывал СРО полностью копировать стандарты и правила с аналогичных государственных, а напротив, позволял творчески подойти к разработке стандартов, исходя из специфики деятельности и особенностей конкретной сферы медицины.Опережающее появление таких документов в частных медицинских организациях, не обладающих необходимой научно-теоретической базой и высоко квалифицированными медицинскими кадрами, 
послужило поводом для слушаний в ГД РФ в ноябре 2012 года. Результатом слушаний стали рекомендации Минздраву разработать порядок проведения экспертизы качества медицинской помощи, оказываемой вне системы ОМС. Кроме того закон о саморегулируемых организациях, который действует в настоящий момент, при исполнении оказался не особенно продуктивным, чему пример - строители. В результате существования данного механизма в строительной сфере России в течение 2,5 лет многие разочаровались в саморегулировании в том виде, в котором оно существует на данный момент. Как показал опыт прошедших лет саморегулирование в строительном бизнесе России легализовало коррупционную составляющую, существовавшую при лицензировании, саморегулируемые организации превратились в бизнес структуры, а само саморегулирование - в очень прибыльный бизнес. Повыше указанным причинам заместитель председателя комитета Госдумы по охране здоровья и вице-президент Национальной медицинской палаты С.Б.Дорофеев высказал мнение о том, что существующий закон о саморегулируемых организациях не подходит для здравоохранения99.

Согласно ст. 76закона «Об основах охраны здоровья граждан в Российской Федерации» № 323-ФЗ статус профессиональной медицинской организации приравнивается к общественному, что даёт право профессиональной медицинской организации участвовать в работе территориальных фондов ОМС и заключать с ними тарифные соглашения. Законодательный механизм институализации данного права до конца не сформирован. В этой связи Государственная Дума планировала в 2013 году начать обсуждение концепции законопроекта о саморегулировании врачебной деятельности через профессиональные медицинские организации и

${ }^{99}$ Алисина Л. Мы за конструктивное сообщество, нацеленное на достижение результата. Дата публикации 22.04.2013.[Электронный ресурс].-Режим доступа http://www.evrika.ru/article/1452 
объединения, которое состоялось лишь во второй половине 2018 года, когда были законодательно закреплены требования к профессиональным медицинским НКО и их ассоциациям, которым могут быть переданы отдельные функции в сфере охраны здоровья и предоставлено право участвовать в деятельности уполномоченных федеральных органов исполнительной власти и фондов обязательного медицинского страхования, а также в разработке программ государственных гарантий бесплатного оказания гражданам медицинской помощи (в соответствии с ч. 5 ст. 76 Федерального закона от 21 ноября 2011 г. № 323-Ф3 «Об основах охраны здоровья граждан в Российской Федерации» ${ }^{100}$.

Смена правительства в мае 2012 года породила в обществе надежды, что со сменой персонального состава кабинета, изменится и его политика. Этому способствовали отставки самых критикуемых министров - образования и здравоохранения. Именно они стали олицетворением непопулярных отраслевых реформ. Претензий к ним, по сути, было две - игнорирование мнения профессиональных сообществ и утверждение в качестве основной цели реформ - принципа финансовой оптимизации ${ }^{101 .}$ Надежды оказались не состоятельными.

В качестве сложившейся общественной структуры, абсорбирующей интересы и потребности профессионального врачебного сообщества, позиционируется Национальная медицинская палата. Сегодня теоретически и практически стало возможным формирование Национальной медицинской палатой экспертного взгляда на основе мнений и потребностей

${ }^{100} Э$ Эсперты: Эффективность саморегулирования в медицине напрямую зависит от инициативности врачей.М.Шувалова.30.11.2018. [Электронный ресурс].-Режим доступа: https://www.garant.ru/ news/1231369/

${ }^{101}$ Карцев Д., Хуцишвили К., Лейбин В., Веселов А. /2012 год фиктивных перемен. «Русский репортер» №49 (278). [Электронный ресурс].-Режим доступа:http://expert.ru/russian_reporter/2012/49/2012god-fiktivnyih-peremen/?partner=988462. Дата обращения 03.01.2013. 
врачебных кадров.При этом Национальная медицинская палата может инициировать «тарифный» механизм работы с региональными ТФОМС для оплаты патентных инноваций в процессе модернизации практического здравоохранения. Кроме этого Национальная медицинская палата может вносить предложения в департамент анализа, прогноза и инновационного развития здравоохранения РФ по использованию врачебных патентных новаций в части исполнения и доработки федеральных стандартов оказания медицинской помощи там, где они до сих пор не разработаны.

Большие ресурсные возможности работы непрофессиональных общественных организаций демонстрирует ОП-общественная палата РФ, которая открыла 21 января 2013 года для врачей и пациентов интерактивную приемную по контролю за реформой и модернизацией системы здравоохранения и демографии. По электронному адресу zdorovie@oprf.ru и по телефону 8-800-700-8-800 граждане могут задавать вопросы, связанные с модернизацией и реформой системы здравоохранения. Информацию о текущей реформе здравоохранения и конкретные предложения граждан эксперты комиссии планировали использовать для подготовки Общественной палаты РФ ежегодных рекомендаций профильным госорганам. Председатель Комиссии по контролю за реформой и модернизацией системы здравоохранения и демографии ОП РФ Николай Дайхес считает, что всегда важно иметь обратную связь о реформе и реальном положении дел из разных регионов России: будь то конкретные жизненные истории, жалобы или общий экспертный взгляд на проблему ${ }^{102}$.

${ }^{102}$ Общественная палата РФ открыла интерактивную приемную для врачей и пациентов. ИА «Гарант».21.01.13.[Электронный peсурс].- Режим доступа http://www.univadis.ru/medical_and_ more/Local_Medical_News_Detail?link=/RU/Local_Medical_News/ Obschestvennaya-palata-RF-otkryla-interaktivnuyu-priemnuyu-dlyavrachej-i-pacientov/(language)/rus-RU\&id=993845 
Обратная связь о реформе и реальном положении дел действительно необходима для развития и укрепления конкурентоспособности сферы российского здравоохранения. Также необходим полный пересмотр системы формирования собственной конкурентоспособности медицинских услуг для большинства частных и государственных предприятий здравоохранения. Во всех странах с рыночной экономикой уже на протяжении многих лет и государственные, и частные предприятия здравоохранения работают в условиях жёсткой отраслевой конкуренции, управляя своими конкурентными преимуществами, эффективно используя при этом не только дефицитные финансово-экономические ресурсы, но и нематериальные активы, являющиеся объектами интеллектуальной собственности.

В условиях рыночной экономики для любого участника рынка здравоохранения крайне актуальной является задача формирования его конкурентоспособности. Вместе с тем в настоящее время не существует целостной теории конкурентной способности хозяйствующих субъектов в сфере Российского здравоохранения. Отсутствует так же и общепринятое определение самой категории конкурентоспособности предприятий здравоохранения. Вопросы оценки и повышения конкурентоспособности на уровне хозяйствующего субъекта на рынке медицинских услуг практически недостаточно изучены и разработаны. Не установлена зависимость между конкурентной способностью предприятия здравоохранения и конкурентоспособностью медицинских услуг. Более детальной разработки требуют вопросы особенностей конкуренции на рынке медицинских услуг.

Недостаточная степень разработанности проблемы формирования конкурентоспособности государственных и частных предприятий здравоохранения, а также теоретическая и практическая не разработанность 
исследований по обозначенной проблематике в условиях экономического спада РФ представляют развитие этой области здравоохранения в ближайшей перспективе достаточно проблемным ${ }^{103}$.

На практике источником развивающей и адаптирующей информации для принятия решений в вопросах развития, выбора вида оказания медпомощи часто выступает легкодоступная реклама, в том числе исходящая от представителей фармацевтических компаний. Влияние представителей фармацевтических компаний на принятие клинических решений настолько существенно, что их часто называют «медицинскими бомбардировщиками»104. В США эта практика адаптирована государством. И она может давать быстрые результаты, ноне всегда положительные.

В России с учетом специфики экономического развития и ограниченных возможностей внедрения российских инноваций, в том числе основанных на достижениях доказательной медицины, широкое распространение получила отечественная практика стандартов медицинской помощи, в том числе на высоко технологичные и высоко затратные медицинские услуги.

Государственные учреждения здравоохранения, представляющие собой этап специализированной и высокотехнологичной медицинской помощи, часто являются многопрофильными, например областные (краевые, республиканские) больницы так как, пользуясь стандартами оказывают социально значимую и дорогостоящую высокотехнологичную медицинскую помощь. При этом ресурсное обеспечение стандартов медпомощи, социально

${ }^{103}$ Арабчиков К.Н. Формирование конкурентоспособности предприятий частной системы здравоохранения.Автореф дисс. канд. экон.наук.Москва.2011.26с.

${ }^{104}$ Shaughnessy AF,Slawson DC.Pharmaceunical representatives. DMJ 2005;312:1494-5. 
значимой, высоко технологичной дорогостоящей медицинской помощи, через систему государственных закупок, осуществляет государство.

Действующий в России с 2006 года Федеральный закон № 94-ФЗ о госзакупках со стороны участников закупок и чиновников вызывает справедливую критику. В числе основных недостатков эксперты выделяют некачественный отбор продукции и услуг при госзакупках по данному федеральному закону. Единственным критическим критерием выбора поставщиков продукции и услуг по Ф3-94 является минимальная цена. Одного этого критерия недостаточно для обеспечения качественных госзакупок. Поэтому, вероятно, с 2014 года вступили в силу новые правила госзакупок, которые разработаны в законе о федеральной контрактной системе (ФКС). Новые положения закона о ФКС регулируют не только стадии размещения госзаказа, но и этапы его прогнозирования, планирования, мониторинга и оценки эффективности. При этом госструктуры обязаны обосновывать начальную цену контракта и способ определения поставщика. На первом этапе в 2014-2015 годах обязательному обсуждению подлежали закупки на сумму свыше 1 млрд. руб. Указанные нововведения, по мнению разработчиков, должны улучшить контроль и качество госзакупок, ликвидировать так называемые «откаты» ${ }^{105}$ при выборе поставщиков товаров и исполнителей услуг. Из-за сложностей нового закона ФКС его настройка растянулась на несколько лет. Как указывали критики, нельзя рассчитывать, что новая система ФКС сразу начнёт работать в полноформатном масштабе.

На усиление контроля за государственными и муниципальными закупками лекарственных препаратов,

${ }^{105}$ Новые правила ликвидируют откаты? Газета областные вести в каждый дом. ООО «Информационное агентство ВОЛГА»,г.Волгоград№20.,30.05.2013.С.5. 
направлен переход на референтное ценообразование для государственных закупок лекарственных препаратов и, таким образом, уменьшение отклонений от референтной цены при закупках. Планируемое нововведение ${ }^{106}$ является одним из пяти направлений приоритетного проекта в области здравоохранения в течение ближайших нескольких лет (2016-2019гг), поскольку именно при их реализации Минздрав планирует достичь новых позитивных показателей в повышении качества, доступности медицинской помощи, в улучшении демографии.

По действующей системе регулирования госзакупок российских медицинских изделий имеющих плохую коньюктуру на международных рынках Россия, не случайно, при присоединении к $\mathrm{BTO}^{107}$ не ратифицировала соглашение по правительственным закупкам, в котором исключены преференции для российских товаров. Новая версия соглашения ВТО вступила в силу в апреле 2014 года, и большинство стран, подписавших оригинальную версию соглашения, уже успели подписать новую. По условиям ВТО Россия должна инициировать переговоры о присоединении к соглашению в течение 4 лет с момента вступления 22 августа 2012 года в ВТО ${ }^{108}$. За истекшее время РФ снизила пошлины более чем на 400 импортируемых из-за рубежа товаров. С вступлением России в ВТО надежды российских экспортеров на облегчение доступа на международные рынки не оправдались. К уже существующим

${ }^{106}$ Брифинг Министра Вероники Скворцовой по завершении заседания президиума Совета при Президенте РФ по стратегическому развитию. Электронный ресурс: http://edu.rosminzdrav.ru/news/ novosti/news/brifing-ministra-veroniki-skvorcovoi-po-zavershenii$\mathrm{za} / 05.09 .2016$.

${ }^{107}$ Борзова М.Вступление России в ВТО и регулирование фармрынка.Ж.Ремедиум.,№11,2012.,с.8-19.

${ }^{108}$ Пункт 1142 доклада рабочей группы по присоединению РФ к BTO. 
санкционным экономическим ограничениям против российских производителей товаров и услуг США и страны ЕС ввели новые.

Применяемые сегодня в отношении России ограничительные меры находятся в прямом противоречии с принципами ВТО, что позволяет говорить о том, что возможности членства в этой организации в ближайшей перспективе вряд ли обеспечат России ожидаемые торгово-экономические преференции ${ }^{109}$. Снижение Россией импортных пошлин может привести к тому, что некоторые товары станет невыгодно производить внутри страны, в том числе приобретаемые по системе госзакупок.

В связи с необходимостью выполнения требований ВТО и сохранением поддержки производителей отечественных товаров остро встал вопрос локализации производства зарубежных производителей медицинских изделий на территории России, который обсуждался 23 января 2013 года на Экспертном совете в Федеральной антимонопольной службе. Вопрос был актуализирован ПП РФ «Об установлении ограничений при поставке медицинских изделий для государственных и муниципальных нужд».Ключевой темой встречи стали перспективы развития индустрии российских медицинских изделий в случае вступления в силу данного проекта постановления Правительства РФ110. Часть положений указанного проекта ПП носит прямой запретительный характер и может существенно лимитировать доступ на российский рынок зарубежной продукции стран участников ВТО, не имеющих локальной производственной площадки.

${ }^{109}$ Чем обернулось России членство в ВТО. Graf Montecristo - Окт 24, 2015. Электронный ресурс-http://moiarussia.ru/chem-obernulosrossii-vstuplenie-v-vto/.

${ }^{110}$ Вопросы локализации производства медицинских изделий на территории России обсудили на Экспертном совете в федеральной антимонопольной службе.Ж.Лечащий Врач.,февраль 2013,№2.c.5-6. 
Участники экспертного совета лишь высказали различные точки зрения и поделились своими предложениями относительно структуры дальнейшей работы над вопросом локализации производственных площадок на территории России.

Присоединение к ВТО пока не препятствует преференциям России собственных госзакупок на внешнем рынке. Но принятие и вступление в силу проекта постановления правительства «Об установлении ограничений при поставке медицинских изделий для государственных и муниципальных нужд» для стран участников ВТО не имеющих собственных производственных площадей на территории России может отсрочено инициировать утрату Россией преференций госзакупок на рынке стан участников ВТО. Кроме этого не ясно, в какой мере принимаемое ПП РФ способствует качеству товаров и услуг медицинской помощи для россиян. В частности, поступающие по линии госзакупок с внешнего и внутреннего рынка медицинские изделия и товары, в том числе входящие в ВМП, реализуются для населения уполномоченными коммерческими структурами по завышенным ценам с целью получения максимальной прибыли.

Многие пенсионеры, инвалиды, работающие члены многодетных семей и сельских поселений, имеющих невысокий уровень доходов, вынуждены пользоваться мерами государственной социальной поддержки населения. По мнению европейских экспертов не менее $17 \%$ россиян живут за чертой бедности и нуждаются в мерах социальной поддержки. На этом фоне растёт общественная обеспокоенность доступности для населения не только высоко технологичных, но и обычных медицинских услуг и медицинских изделий. В результате реализация медицинских услуги изделий оказалась под жестким государственным контролем, который ежегодно дискредитирует растущее количество раскрываемых финансовых 
преступлений и жалоб в прокуратуру со стороны гражданского населения ${ }^{111}$.

Конституционная норма о том, что медицинская помощь в государственных и муниципальных учреждениях здравоохранения оказывается гражданам бесплатно, конкретизирована определением границ «бесплатного» в рамках программы государственных гарантий в соответствии с разработанными стандартами оказания медпомощи. Прикрываясь недостаточным финансированием и ущербностью программы госгарантий многие руководители лечебных учреждений взимают плату с пациентов за бесплатные услуги. В основе не выполнения гарантий лежат недостаточно эффективная экспертная проверка исполнения медицинскими учреждениями стандартов медицинской помощи, плохая организация и не надлежащее управление регионарными органами власти отпуском медицинских услуг подведомственными учреждениями здравоохранения.

Например, проверка 2010 года деятельности МУЗ КБ№25 г.Волгограда выявила систематическое взимание денежных средств за услуги с приобретением лекарственных средств, которые должны были предоставляться бесплатно за счет средств фонда территориального медицинского страхования ${ }^{112}$. Единственно бесплатной в медучреждении оказалась койка, все остальное пациентам предлагалось покупать за собственные деньги. Нередко население вынуждено пользоваться платными медицинскими услугами вследствие организационноуправленческих недоработок со стороны местных органов

${ }^{111}$ Городские врачи отказывались принимать сельских пациентов. Газета АИФ Волгоград. 29.05.2013.[Электронный документ]-Режим доступа: http://news.mail.ru/inregions/south/34/ society/13288125/?frommail $=1$.

${ }^{112}$ Иванова. О. Нездоровые доходы. Газета «Городские вести». Царицын,Сталинград, Волгоград. №88(479).-2010г. 
самоуправления. Так ЦРБ города Камышин Волгоградской области, согласно полученной лицензии оказалась не вправе осуществлять не только медицинскую помощь в сфере кардиологии, отоларингологии, урологии, офтальмологии, но также проводить ряд лабораторных исследований. При этом в городскую прокуратуру неоднократно поступали жалобы от граждан жителей района на отказы врачей городской больницы в оказании медицинской помощи жителям района со ссылкой на место их жительства. В результате, сельские жители оказались вынуждены сдавать анализы в платных клиниках, а медпомощь получать в далеко расположенных друг от друга амбулаториях ЦРБ, имеющих профильные лицензии. В связи с этим перед областным министерством здравоохранения прокурор ${ }^{113}$ поставил вопрос об обеспечении прав граждан на охрану здоровья.

Хотя гарантированные стандарты оказания медпомощи утверждены приказами Минздравсоцразвития России и рекомендованы для федеральных специализированных медицинских учреждений, повсеместно существующие финансовые нарушения существенно ограничивают их применение.

Важной организационной причиной, дискредитирующей стандарт оказания медпомощи, является отсутствие четкого понятия дефиниции определения стандарта. В приказе заместителя министра здравоохранения и социального развития России (08.07.2006 года №3604-ВС) дано следующее понятие стандарта: «Стандарт медицинской помощи-объём медицинской помощи, предоставляемой больному по определенной нозологической форме в соответствии с «МКБ-Х»за счет средств федерального бюджета

${ }^{113}$ Городские врачи отказывались принимать сельских пациентов. Газета АИФ Волгоград. 29.05.2013.[Электронный документ].-Режим доступа: http://news.mail.ru/inregions/south/34/ society/13288125/?frommail=1. 
в федеральных специализированных медицинских учреждениях, подведомственных Федеральному агентству по здравоохранению и социальному развитию. Стандарт медицинской помощи включает перечень диагностических и лечебных медицинских услуг с указанием количества и частоты их применения, перечень используемых лекарственных средств с указанием разовых и курсовых доз, перечень дорогостоящих изделий медицинского назначения (включая имплантанты, эндопротезы и т.д.),перечень компонентов крови с указанием количества и частоты использования».

Указанные методические рекомендации определяют также основные функции стандарта медицинской помощи: для расчета стоимости оказываемой медицинской помощи; в целях установления требований к оказанию лечебных и диагностических услуг больным при определенных нозологических формах заболеваний; для организации деятельности по контролю качества оказываемой медицинской помощи.

Утвержденные федеральным органом исполнительной власти в сфере здравоохранения стандарты медицинской помощи предназначены также для конкретизации ограничений объемов медицинской помощи, оказываемой населению в рамках государственных гарантий и оплаты CMO. Вместе с тем, в утвержденных стандартах не указаны: лекарственная форма применения медикаментов, коды, торговые наименования материалов и изделий медицинского назначения, что не позволяет уточнить тот или иной элемент медицинской помощи, практически осуществить проверку соответствия оказанной медицинской помощи стандарту, в том числе в части обоснованности назначений лекарств.

Современные стандарты оказания медицинской помощи подразумевают мощную синергию морально-этических, нормативно-правовых, финансовых, 
организационных, технологических составляющих. Общеотраслевое централизованное решение проблемы стандартизации на практике представляется «сизифовым трудом», так как темпы развития новых технологий и знаний в медицине в значительной степени опережают темпы разработки данных стандартов. ${ }^{114}$

С одной стороны, число разработанных федеральных и региональных медицинских стандартов сегодня исчисляется тысячами. С другой стороны, совершенно очевидно, что деятельность по стандартизации в здравоохранении требует большей системности и суботраслевого подхода с учетом постоянного повышения качества и количества разных видов стандартов (стандарты оснащения и стандарты оказания медицинской помощи). Для решения этих вопросов в 2013 году в Минздраве России создан Департамент анализа, прогноза и инновационного развития здравоохранения. В задачи этого структурного подразделения министерства входят вопросы, касающиеся стандартизации в отрасли. Здесь также надлежит разрабатывать методологию по дальнейшему внедрению порядков и стандартов медицинской помощи. Департамент должен разрабатывать и предлагать механизмы управления качеством медицинской помощи ${ }^{115 .}$ По мнению первого директора созданного Департамента анализа, прогноза, развития здравоохранения и медицинской науки Ксении Шеховцовой в истории российского здравоохранения впервые утверждены стандарты и порядки, которые носят не рекомендательный, как это было ранее, а обязательный характер. При этом к началу 20132., утвердив порядки и стандарты,

${ }^{114}$ Серегина И.Ф., Пивень Д.В., Кицул И.С., Саморегулирование в здравоохранении. Вестник Росздравнадзора. №1.2010.

${ }^{115}$ Стандарты о двух концах. Интервью К.Шеховцовой медицинской газете. 25.04.2013.[Электронный ресурс].- Режим доступа http://www.evrika.ru/article/1456 
здравоохранение подошло к этапу, когда на практике можно внедрять элементы аудита качества.

Кроме выше рассмотренных, имеются и другие связанные с реализацией стандартов проблемы оказания медпомощи. Отдельного рассмотрения, в частности, заслуживает проблема оснащенности или ресурсного обеспечения стандартов. Существующее минимальное ресурсное обеспечение стандарта, не соответствует требованиям реальности. Попытки обозначить данную проблему отдельными представителями региональной власти не имели и имеют эффекта. Основных причин две. Первая - отсутствие постоянного внимания к данной проблеме со стороны депутатского корпуса и её коньюктурность преимущественно накануне предстоящих выборов в органы власти. Вторая-отсутствие взвешенного подхода в её решении. Так депутат гордумы г.Волгограда, член партии «Справедливая Россия» Ирина Карева в апреле 2013 года отмечала, что оказание медицинской помощи тормозилось из-за отсутствия ресурсного обеспечения. Решение данной проблемы представитель власти видела в постоянном анализе качества оказания медпомощи и всех видов её доступности ${ }^{116}$.

В реальности кроме постоянного анализа качества и доступности оказания медпомощи необходимы кардинальные изменения менеджерских компетенций органов управления здравоохранением, обеспечивающих координацию оказания медицинской помощи не в отдельно взятых организациях, а увязку отдельных звеньев оказания медицинской помощи в контексте комплексного улучшения управления деятельностью территориальных медицинских организаций. Достижению этой цели наиболее оптимально отвечает модель управляемой медицинской

${ }^{116}$ Калашников.Д. На достойном уровне. Газета «Областные вести в каждый дом». Издатель ООО «Информационное агенство ВОЛГА»,г.Волгорад.2013.№12., 18 апреля 2013. С.2. 
помощи ${ }^{117}$, которая обеспечивает: общую систему экономических интересов отдельных звеньев оказания помощи; координацию и преемственность в работе отдельных звеньев; активное участие врачей в социологических вопросах направленных на поиск ресурсосберегающих технологий; разработку клинических стандартов и критериев обоснованности медицинской помощи; выбор наиболее рационального экономического варианта лечения без ущерба качества оказания медпомощи. Сразу отметим, что критериям ресурсосберегающих технологий отвечают врачебные патентные разработки, которые вписываются в модель управляемой медицинской помощи.

Для реализации принципов и методов управляемой медпомощи в местных органах власти необходима организация подразделений по управлению использованием ресурсов. Работу данных подразделений могут и должны курировать профессиональные врачебные сообщества. Последние обеспечивают: разработку вопросов достижения более рационального использования ресурсов при лечении различных нозологий путём сбора информации по объёмам и стоимости медпомощи на различных этапах её оказания с целью сравнения и определения возможности достижения экономии; разработку клинических стандартов и критериев обоснованности того или иного вида медпомощи; установление контрольных цифр по объёмам оказания услуг по каждому звену системы оказания медицинской помощи; проведение мониторинга оценки выполнения поставленных задач.

Кроме выше указанного, профессиональные врачебные сообщества активно вовлекают в процесс

${ }^{117}$ Финансирование здравоохранения./Методические рекомендации по развитию здравоохранением: совершенствование управления здравоохранением, организация общей врачебной практики, укрепление здоровья и профилактика неинфекционных заболеваний. Москва,2003.46с. С.30-31. 
планирования управляемой медпомощи все заинтересованные стороны (менеджеров органов управления здравоохранением, ТФОМ, страховых компаний, лечебно-профилактических учреждений);обеспечивают встречный характер процесса планирования сверху-внизи снизу-вверх не ограничиваясь, при этом, доведением до низовых уровней разработанных наверху показателей; закрепляют достигнутые договорённости в соглашениях между региональным органом управления здравоохранением, территориальным фондом ОМС активно используя, при этом, изменения «тарифов» оплаты стандартов медпомощи, согласование финансирования объёмов медицинской помощи с главами муниципальных образований; принимают участие в мониторинге за выполнением Территориальной Программы Государственных Гарантий и муниципальных заказов, осуществляют в случае необходимости их корректировку. 


\subsection{0борот медицинских инноваций и особенности реализации высокотехнологичной медицинской помощи в России}

В стандартах оказания медпомощи обращает на себя внимание представленность в документе высокотехнологичной медицинской помощи одной строкой, содержащей наименование из утвержденного перечня ее видов и кратности ее оказания на 100 пациентов (в диапазоне от 0,1 до 1,0). Причем значение 1,0 в документе встречается редко. Практически это означает, что медицинское учреждение не может оказать больному высокотехнологичную медицинскую помощь из-за недостаточной кратности её указания в стандарте на 100 пациентов и отсутствия, вследствие этого, гарантированных средств федерального бюджета, например, на имплантацию кардиовертера-дефибрилятора при нарушениях ритма сердца.

Также в стандартах медпомощи не указаны результаты лечения, которых предполагается достичь. Отечественные патентованные способы диагностики и лечения ориентированы не только на раннее выявление патологии, но и достижение оптимальных результатов её лечения. Последнее особенно важно для профилактики развития осложнений социально-значимых и быстро растущих по распространенности заболеваний, таких как артериальная гипертония, ишемическая болезнь сердца, сахарный диабет, метаболический синдром. Внедрение и использование патентованных способов ранней диагностики и профилактики сосудистых осложнений артериальной гипертонии, ишемической болезни сердца, сахарного диабета, метаболического синдрома в государственно-частных учреждениях здравоохранения может дать существенную экономию федеральных бюджетных средств.

В настоящий момент в России существует три направления развития инновационных медицинских 
технологий: инвесторы, компании, импортирующие зарубежные инновационные разработки, и российские изобретатели. В области инвестирования в медицинские инновации российская специфика такова, что основным инвестором в передовые медицинские технологии выступает государство, которое не является «идеальным» бизнесменом. В 2008 году из госбюджета было выделено 19,4 млрд. руб. на строительство центров новых медицинских технологий в Пензе, Хабаровске, Астрахани и др. При поддержке государства развивается медицинское направление в технопарках (Курчатовский, Зеленоградский, Обнинский и др.), где разрабатываются новые методы лечения, лекарственные средства и оборудование, в том числе с применением нано технологий. Но все эти технологии недостаточно быстро развиваются и пока мало доступны для широкой клинической практики.

По мнению ряда экспертов, лучший метод внедрения медицинских инноваций-создание «венчурного» предприятия. В 2006году в России сформировалось несколько государственных частных венчурных фондов. В 2007 году общее положение венчурного капитала составляло около 39 млрд. рублей. В 2010 году в России было зарегистрировано 108 венчурных фондов, из них активных 43. На сегодняшний день в России венчурное инвестирование в медицине не получило широкого распространения. Для поддержки проектов возможно привлечение средств различных финансовых институтов, включая пенсионные фонды России. Продуманное инвестирование накопительной части трудовых пенсий, которая непрерывно обесценивается инфляцией может не только защитить, но и приумножить пенсионные накопления. Однако руководство Банка России из-за риска образования огромной «инфляционной»дыры в бюджете ПФРФ отрабатывает необходимость версии полной отмены накопительной системы трудовых пенсий. Против этого выступил глава 
Сбербанка РФ Герман Греф, который через прессу опубликовал открытое письмо премьер-министру Дмитрию Медведеву о необходимости сохранить всё в ПФ в нынешнем виде в силу ряда причин, из которых выделил как главную - утрату репутации среди инвесторов из-за частой смены правил игры и отсутствия гарантии финансовых вложений в России ${ }^{118}$.

Другая немаловажная причина низкой реализации и рискованного инвестирования в медицинские инновационные проекты состоит в том, что для подготовки инвестиционного анализа и технико-экономического обоснования инновационного проекта, необходимо составить бизнес-план как минимум на 12 лет, рассчитать сроки окупаемости и прибыльности проекта, что на практике для авторов медицинских инноваций оказывается очень сложным, длительными часто недостижимым процессом. По этой причине Российский бизнес не готов к инвестированию в медицинские инновации. Готовые бизнес планы на платной основе представляют различные фирмы. По мнению гендиректора консалтинговой группы компаний«Synopsis» ${ }^{19}$ Е.Б.Емельяненко, авторами инновационных проектов и технологий в области медицины и фармации в России являются не бизнесмены, как в европейских странах, а ученые-исследователи и врачи. Российские изобретатели, как правило, не умеют «продавать» свои идеи инвесторам так как руководствуются чисто научными интересами. Авторы медицинских инноваций в России зачастую не имеют базового бизнес образования и поэтому

118Чеховский Н. Накопительные пенсии отменяются. 19.09.2012. [Электронный ресурс].-Режим доступа: http://svpressa.ru/economy/ article/58840/\#24smi

${ }^{119}$ Особенности инвестирования в медицину.Емельяненко Е. Б. SCR GROUP synopsis consulting \&research. [Электронныйресурс].-Peжим доступа: http://www.medee.ru/post/view/9287. Дата обращения 02.02.2013. 
не имеют четких представлений о правилах игры на рынке и, как правило, не знают сможет ли их изобретение занять свою нишу на рынке. Потенциальному частному инвестору сложно понять порой язык медицинских терминов и оценить возможность прибыльности лечебно-диагностической технологии с точки зрения существующего рынка. Проблему составления бизнес планов частично решают консалтинговые компании подобные SYNOPSIS, бизнес-планы которой разработаны с учетом специфики развития экономики РФ и существующих подобных проектов за рубежом. Перепродажа, копирование и публикация информации из инфопродуктов SYNOPSIS запрещены, если предварительно не оговорены.Недостатком для экономики России является факт, что полные бизнес проекты SYNOPSIS не могут быть представлены потенциальным инвесторам и правообладателям инновации без предварительной оплаты до начала получения доходов от использования проекта.

Другим подходом решения обсуждаемой проблемы является формирование отраслевой инновационной политики в здравоохранении, где потребность в разработке и внедрении медицинских инноваций очень высока и в перспективе будет только нарастать. В этой связи в литературе обсуждается вопрос формирования кластеров инновационной медицины ${ }^{120}$, целью которых является создание замкнутого цикла жизни медицинских инноваций включая разработку, внедрение и их практическое применение.

Новые отношения, возникающие внутри кластера, стимулируют инновационную деятельность, способствуют развитию прогрессивных технологий и

${ }^{120}$ Беляков В.К., Пивень Д.В., Антонов Д.П. О проблемах инновационной политики в отечественном здравоохранении и необходимости создания кластеров медицинских инноваций. Ж.Менеджмент в здравоохранении.2008.№1.C.4-11. 
совершенствованию всех этапов совместной экономической деятельности носителей инноваций. Взаимосвязи внутри кластера ведут к разработке новых путей и конкурентных преимуществ на глобализированных рынках, порождают новые экономические преимущества в результате действия синергетического эффекта инвестиций в специализированные исследования всех взаимосвязанных участников кластера, в развитие родственных технологий, в информацию, в развитие инфраструктуры и в человеческие ресурсы. Важнейшей институциональной предпосылкой, обеспечивающей успех модернизации экономики и медицины является возрастание роли частногосударственного партнерства. Государство должно создавать условия для снижения транзакционных издержек взаимодействия участников медицинских и биотехнологических кластеров, способствовать накоплению в них интеллектуального капитала, повышать качество жизни в кластерах и регионах.

Применение новой кластерной модели экономического роста в национальной экономике и медицине возможно при доминирующем положении институтов, ответственных за создание новых знаний. К таким фундаментальным институтам относят структуры интеграции государственно-частного партнерства, бизнеса и науки. В настоящее время в России отсутствуют институциональные структуры, эффективно консолидирующие усилия государства, среднего, малого бизнеса и науки. Напротив, сложились отношения, которые в российских институциональных условиях способствуют монополизации инноваций и описываются как «ловушки технологий» ${ }^{121}$. Примером являются наукограды, в которых государство, с участием огромных зарубежных и российских корпораций, используя откровенные формы интеллектуального

${ }^{121}$ Исаева Т.Н. Качество жизни населения в условиях модернизации экономики. Автореф дисс...канд.экон.наук. Москва.2011. 
империализма, торгует выгодами заключаемых и действующих контрактов.

Медицинские инновации, могут воплотиться в жизнь усилиями всех участников модернизации экономического процесса, включая представителей науки, практического здравоохранения, органов власти, предпринимательского, страхового и изобретательского бизнеса. Вопрос их интеграции и взаимодействия на региональном уровне требует компетентного участия руководителей регионов и соответствующих структур, в противном случае процесс их взаимодействия может не произойти, что является недостатком кластерного подхода. Работе по созданию кластеров, как правило, предшествует подготовительный этап, включающий выявление и мотивацию потенциальных участников, включая врачебные изобретательские кадры, представителей предпринимательского и страхового бизнеса, разработку общей стратегии пилотных и стратегических проектов, создание центров медицинских инвестиций и инноваций, возможность достижения ими стадии саморегуляции. Прохождение всех этапов формирования инновационных кластеров с учетом сложившейся в мире кризисной экономической ситуации для России теоретически возможно, но практически не везде реально.

Создание по инициативе Федерального центра «Агентства инновационного развития РФ», а также центров кластерного развития подобного Обнинскому, созданному ещё в 2009 году, в целом не решает обсуждаемой проблемы. В сентябре 2010 года Дмитрий Медведев подписал закон о создании в России инновационного центра Sk-«Сколково», который в перспективе станет центром развития новых технологий. Многие обозреватели считают, что с этим проектом Россия отказалась от иллюзий умения сама что-либо делать и готова покупать западные технологии. Кроме российских компаний, в Sk планировались разместиться лаборатории финской Nokia, немецкой Siemens, 
американских Microsoftu Google, французской Bouygues, индийской TataSons.3а шесть лет Sk получил не менее 100 млрд. рублей. На строительство научного центра было выделено \$3,6 млрд., что свидетельствует о том, что $\$ \mathrm{k}$-самый важный в России государственный проект. Самые актуальные проблемы, решаемые в Skэто: зарубежные и российские капиталовложения в Sk; привлечение в Skyехавших из страны российских учёных. Необходимость возврата ученых не вызывает сомнений. Привлечение сомнительных лекторов и инвесторов, и в связи с этим учёт расходов- вызвал и вызывает у следственных органов немало вопросов. Далеко не однозначно следственными органами оценивается и эффективность научных контрактов в Sk.

19 апреля 2013 года СКР возбудил уголовное дело против вице-президента фонда Sk Алексея Бельтюкова. Он был обвинён в незаконной передаче денег депутату Илье Пономарёву. В настоящее время депутат ГД РФ Пономарёв, обосновавшись на Украине, находится за пределами действий следственного комитета России. По версии СКР, из выделенных фондом Sk 750000\$ на прочтение десяти лекций, Илье Пономарёву предназначалось $300000 \$$. Следствием было установлено, что в депутат ГД РФ И.Пономарёв деньги получил, но прочитал лишь две лекции «общим хронометражем менее получаса» ${ }^{122}$. В 2016 году по данному факту следственными органами РФ проведена проверка и возбуждено уголовное дело.

Кроме сомнительных научных контактов научный совет Sk - российского «города будущего» допустил к утверждению в числе первых, и некоторые сомнительные проекты. Среди них проект «Оздоравливающие сотовые телефоны», на разработку которого планировалось 315 млн. рублей, с планом продаж на $\$ 30$ млн. «Сканер-телефон»,

${ }^{122}$ И.Вексельберг: «Сколково» может подать в суд на Пономарёва. Ведомости. 25 апреля 2013. [Электронный ресурс].-Режим доступа: http://news.rambler.ru/18652702/ 
удивительно напоминающий телефон Nokia 3310, должен был «через электроды оказывать индивидуально дозированное лечебное воздействие на участки кожи импульсными токами, нормализуя нарушенные функции органов и систем» $^{123}$. При этом разработчики не смогли привести убедительных медицинских доказательств целебных свойств и функций проекта чудо-техники.

В качестве примера «диагностических процедур», которые не базируются на научном фундаменте, не прошли надлежащим образом контролируемых клинических испытаний и поэтому не приемлемы с позиций доказательной медицины для широкой клинической практики, отечественными и зарубежными ${ }^{124}$ исследователями отмечена заявленная в оздоравливающем сканер-телефоне электродермальная диагностика. Суть метода электродермальной лечебно-диагностической методики связана с измерением электрического сопротивления кожи до и после какого-либо воздействия. Специальные исследования, подтверждающие достоверность теста, в широких масштабах не проводились ${ }^{125}$. При сравнительных исследованиях пациентов с пыльцевой аллергией в г.Саратов отсутствовала корреляция результатов электропунктурной диагностики с анамнезом и положительными кожными пробами. По мнению исследователей из Саратова лечебно-диагностические возможности теста электропунктуры близки нулевому значению.

${ }^{123}$ Бояринцев В.И., Лобанов Д.В.Силиконовая долина и «Сколково». В кн:СТИВ ДЖОБС.Повелитель гаджетов или икона общества потребления.-М.:Книжный мир,2012.-256с.

${ }^{124}$ Паттерсон Р.,Греммер Л.К.,Гринберг П.А.Аллергические болезни:дианостика и лечение.Пер. с англ.под ред.А.Г.Чучалина (гл. ред.).М.ГОЭТАР МЕДИЦИНА,2000.768с.

${ }^{125}$ Астафьева Н.Г.,Кобзев Д.Ю. Между верой и знанием:официальная, альтернативная и комплементарная медицина в лечении астмы и аллергии. Ж.Лечащий врач 2012.№10.С.74-77. 
Премьер-министр России и глава Попечительского Совета Фонда «Сколково» Дмитрий Медведев 19 сентября 2012 года посетил первое здание иннограда «Сколково»,где провел заседание совета по модернизациии выступил на биомедицинской конференции Фонда «Сколково» по инновациям в медицине. Там же министр здравоохранения и социального развития Вероника Скворцова рассказала на заседании Совета о наиболее перспективных проектах России в области биомедицинских технологий ${ }^{126}$. При этом она отметила несколько направлений биомедицинских клеточных технологий, готовых к запуску в ближайшей среднесрочной перспективе к 2016 году. Вопросы возможных изменений сроков, необходимости ограниченных и достаточно продолжительных клинических исследований, предшествующих широкому внедрению результатов новых биотехнологий, на конференции не обсуждались, несмотря на растущий во всём мире разрыв между достижениями фундаментальной науки и внедренными в клиническую практику инновациями. Как показывает международный опыт, внедрение недостаточно проверенных биотехнологических инноваций в клиническую практику может сопровождаться серьезными побочными медико-социальными эффектами. Последнее особенно актуально для инноваций на базе нано технологий, активно разрабатываемых госкорпорацией Роснано. При этом не каждая технологически перспективная и коммерциализируемая инновация может приносить пользу, особенно без надлежащих длительных клинических испытаний. В частности, новая зарубежная нано технология использование нано частиц в аэрозольно-таргетной доставке препаратов легко преодолевающих гематоэнцефалический барьер при лечении заболеваний головного мозга, оказалась небезопасной. В 2013 году

${ }^{126}$ Астафьева Н.Г.,Кобзев Д.Ю. Между верой и знанием:официальная, альтернативная и комплементарная медицина в лечении астмы и аллергии. Ж.Лечащий врач 2012.№10.С.74-77. 
некоторые передовые зарубежные лаборатории возобновили изучение вируса птичьего гриппа после годичного добровольного моратория на проведение исследований с этим вирусом. Оказалось, что незначительные модификации вируса H5N1 с помощью нано технологий привело к тому, что вирус птичьего гриппа приобрел способность передаваться между млекопитающими. В связи с этим Кэтлин Эгглсон (KathleenEggleson) из Центра Нано исследований и Технологии Нотр-Дама (Notre Dame's Center for NanoScience and Technology, США) в статье, опубликованной в журнале Nanoscience, подчеркнули, что ученые, занимающиеся исследованиями в нано области, должны помнить ${ }^{127}$ не только о перспективах внедрения инновационных изобретений, но и о безопасности их использования в обществе.

Кроме проблем чисто научного характера мешать успешной разработке любых инноваций, в том числе и в проекте «Сколково», могут две неразрывные составляющие - бюрократия и коррупция. Все условия для их пышного расцвета в Sk созданы: налоговые льготы, неясные, нечеткие условия осуществления деятельности и оценка ее итогов; сложное, противоречивое и не адаптированное под широкое развитие инноваций законодательство; дорогая подмосковная земля, привлечённые зарубежные компании, стремящиеся к освоению федеральных инвестиций. Сложившуюся ситуацию вокруг Sk подтверждают и данные СМИ. В феврале 2013 года Главное следственное управление СКР по обращению ФСБ России в результате проверки в сентябре-октябре 2012 года возбудило уголовное дело о хищении 23,8 млн. руб., выделенных на развитие наукограда «Сколково» ${ }^{128}$. По данным проверки инновационного

${ }^{127}$ Нанотехнологии могут оказаться небезопасными. 08.02.13. [Электронныйресурс].-Режимдоступа: http: //www.univadis.ru / medical_and_more /Local_Medical_News_Detail?link= /RU/ Local_ Medical_News / Nanotehnologii-mogut-okazat-sya-nebezopasnymi/ (language)/rus-RU\&id=944518

128«Фильтр «Сколково»» газета «Ведомости» от 19.02.2013, №27 (3289). 
центра Счётной палатой установлено, что в субсидиях, направленных на реализацию проекта “Сколково”, отсутствуют конкретные целевые показатели в привязке к срокам их реализации, что создает риски достоверности оценки эффективности их использования. По данным Счетной палаты, с 2010 г. фонд «Сколково» получил от государства 31,6 млрд. руб., а потратил 18,9 млрд. руб. - в два с лишним раза больше, чем предоставил компаниям-резидентам. В открытом сообщении Счетной палаты не конкретизированы проекты, по которым были допущены финансовые нарушения, однако 12 февраля 2013 г. стало известно о возбуждении Следственным комитетом РФ уголовного дела о хищении бюджетных средств в «Сколково» по ч. 4 ст. 160 УК РФ (хищение вверенного чужого имущества путем растраты). Всего по итогам проверки Счётной палаты и МВД в Фонде «Сколково» обнаружены и устранены финансовые нарушения на сумму 3,8 млрд.руб ${ }^{129}$. С 2013 года фонд «Сколково» начал отсев компаний, получивших его гранты или льготы на правах резидентов иннограда, которые не ведут никакой деятельности или занимаются непрофильным бизнесом.

По итогам последней проверки с ноября 2015 по июнь 2016 года инновационного центра «Сколково» ФСБ и Счетной палатой составлено обращение в Генпрокуратуру с главной претензией - у «Сколково» слишком много бюджетных денег, слишком высокие зарплаты, есть необоснованные траты, а почти половина достижений обеспечена дочерней структурой Сбербанка ${ }^{130}$. Прокуратура направила представление президенту фонда «Сколково» по фактам необоснованного расходования грантов отдельными

${ }^{129}$ Мещеряков В. В «Сколково» найдены многомиллиардные финансовые нарушения.18.02.13. [Электронный ресурс].-Режим доступа:http://corp.cnews.ru/news/top/index.shtml?2013/02/18/519336.

${ }^{130}$ Ю.Дивеева. Счетная палата пожаловалась на «Сколково» в прокуратуру. URL доступ: http://www.kp.ru/online/ news/2528085/03.10.2016. 
участниками проекта. За период проверки федеральный бюджет потратил на центр Sk 58,6 млрд. рублей. Эти субсидии составили почти $78 \%$ доходов фонда «Сколково». Однако по закону фонд должен жить в основном на собственные средства. Еще 5,7 млрд. рублей фонд получил от размещения бюджетных денег на банковских счетах. Собственная операционная деятельность принесла фонду только 4,5\% доходов.

В России работают еще два крупных государственных института развития, инвестирующих государственные средства: «Роснано» и Российская венчурная компания (PBK). «Роснано» была создана в 2007 году, а первые проекты закрыла в сентябре 2011 г. В конце 2012 г. «Роснано» проверяла Счетная палата, одновременно появился запрос депутатов Государственной Думы, которые посчитали, что «Роснано» недостаточно активно инвестировала и вкладывала почти исключительно заемные средства.

В связи с запросом ГД руководство «Роснано» уточнило, что всего компания закрыла 40 проектов, в том числе в связи с ухудшением рыночной конъюнктуры или финансового положения проектной компании, сменой менеджмента, несогласием с обязательными требованиями к финансированию проектов или замещением финансирования «Роснано» другими источниками. В силу выше названных причин результаты 5-ти летней деятельности компании более чем скромны но, по утверждению руководства инновационного центра «Роснано», вполне «нормальны».

В 2014 году Следственный комитет возбудил уголовное дело против одного из бывших руководителей «Роснано» Леонида Меламеда по обвинению в растрате 220 млн рублей. Чубайс поручился за него, чтобы его отпустили под домашний арест (под которым он до сих пор, по ноябрь 2016г, и находится).На встрече с Владимиром Путиным по 
случаю девятилетия компании 7 ноября 2016г Анатолий Чубайс (который сам пришел в «Роснано» в 2008 году, через год после основания) привел промежуточные результаты деятельности компании. Построено 73 завода в 32 регионах России, создано 30 тысяч рабочих мест. Изначальная задача обеспечить объём производства в российской наноиндустрии к 2015 году в размере 300 миллиардов рублей перевыполнена на 41 млрд. Компания, планово убыточная до 2017 года, уже в 2014 году получила прибыль в 7 млрд. рублей, а в 2015 году - 17 млрд. рублей. Оппоненты Чубайса утверждают, что источники этой прибыли -это перевод рублей в доллары и, когда \$ дорожает, компания получает прибыль на разнице валютных котировок.

Глава «Роснано» Анатолий Чубайс в 2011 году представил президенту России в качестве перспективного проект электронного учебника для российских школ. Инвестиции в проект составили 150 млн долларов, однако анонсированные учебники не появились.

В центре СМИ в ноябре 2016г оказалось расследование СКР обстоятельств задержки строительства завода по производству вакцин и препаратов в Ярославской области. Предприятие должно было открыться в сентябре 2012 года, однако сроки запуска неоднократно переносились. По версии следствия, задержки строительства предприятия связаны с растратой 1 млрд рублей (\$15,4 млн), принадлежащих компании «Роснано», в рамках проекта по строительству завода «НТ-Фарма» в Ярославской области ${ }^{131}$. Собеседник Би-би-си в «Роснано» признал задержку при строительства завода, однако отметил, что здание уже построено и сейчас там устанавливается оборудование.

Результаты работы «Роснано» постоянно находятся в поле зрения правоохранительных органов, что

${ }^{131}$ Обыски в «Роснано»: пришли за Чубайсом? 16.11.2016.[Электронный ресурс].-Режим доступа: http://www.bbc.com/russian/ features-38005412 
свидетельствует о не достаточной эффективности госинвестиций в данный проект.

Российскую венчурную компанию, созданную в 2006 году генпрокуратура проверила в 2009 году. Проверка установила, что 30 млрд. руб. бюджетных средств переданных РВК расходуются неэффективно: большая часть инвестиций лежит на депозитах в банках. Вскоре после проверки у РВК сменилось руководство ${ }^{132}$, но не политика.

Вопросов целесообразности и главное контроля эффективности федеральных инвестиций немало. Ответы на них возможны следующие.Принятию взвешенных решений по вопросам государственных инноваций и инвестиций в перспективные разработки, включая биотехнологические и медицинские, препятствуют: неимоверное желание «освоить» инвестиционные финансы, в основном, в личных целях; отсутствие знания текущих и срочных проблем инновационного развития практической медицины у руководящих чиновников; отсутствие желания чиновников воспользоваться запросами российских изобретателей в области медицины, незнание проблем последних. Несомненно, необходимы инвестиции с целью приобретения зарубежных технологий. Однако также необходимо широкое участие социально-общественных институтов в усилении контроля эффективности инвестирования государственных бюджетных средств в зарубежные технологии,компании и наукограды. Нельзя при этом забывать о поддержке научных разработок российских учёных-практиков. Последнее может быть намного дешевле, экономически и стратегически не менее эффективно, в сравнении с финансированием «Сколково», «Роснано»,РВК и других крупных проектов.

${ }^{132}$ Фонд «Сколково» перетряхивает портфель проектов.19.02.2013. [Электронный ресурс].-Режим доступа: http: //www.vedomosti.ru/ tech/news/9243301/ filtr_skolkovo\#ixzz2LJ2rw8RU. 
В книге «Крах контрреволюции»(М.,2011) Г.А. Зюганов указывает, что в 2011 году на фундаментальные научные исследования предусматривалось выделение 86 млрд. рублей, а в последующие 2 года $-83,3$ и 83,5 млрд. Более того, судя по недавно одобренной правительством государственной программе «Развитие здравоохранения до 2020 года», в случае реализации бюджетного сценария этой программы в период с 2013г по 2020 год доля финансирования здравоохранения сократится в полтора раза: с 3,4 до 2,5\% от ВВП.

По данным Г.А. Зюганова на прикладные исследования в 2011 году запланировано бюджетных расходов в объёме 13,7 млрд., в 2012 году-12,3 млрд., а в 2013 году6,9 млрд. рублей. Эти цифры подтверждают выводы российского издания «Эксперт», по данным которого в России в 2012 году сколько-нибудь значительного роста стратегических инвестиций в образование и науку, дороги и строительство не произошло, а бюджет медицины сократился ${ }^{133}$.

В последние несколько лет, начиная с 2013 года, как отмечают “mass media”, Федеральный бюджет России последовательно самоустраняется от финансирования социальных сфер. Его расходы на медицину составят 0,4\% ВВП в 2019 году против 0,7\% в 2013-м ${ }^{134}$.

Несмотря на существующие и перспективные бюджетно-финансовые ограничения инвестиций в медицину в РФ развиваются кластеры инновационной

${ }^{133}$ Карцев Д., Хуцишвили К., Лейбин В., Веселов А. /2012 год фиктивных перемен. // «Русский репортер» №49 (278). [Электронный ресурс].-Режим доступа: http://expert.ru/russian_reporter/2012/49/2012god-fiktivnyih-peremen/?partner=988462. Датаобращения 03.01.2013.

${ }^{134}$ Фейнберг А. Эксперты ВШЭ назвали три варианта финансирования образования и медицины.[Электронный ресурс]-Режим доступа: http://www.rbc.ru/economics/18/10/2016/580621ce9a7947575 51744 b8 from $=$ newsfeed 
биофармацевтики. На II-м Обнинском инновационном форуме ${ }^{135}$ проходившем 19 мая 2011 года по теме «Инновации для жизни. Системы инновационного развития» были подписаны соглашения о создании в калужском регионе кластера инновационной биофармацевтики «Парк активных молекул» при содействии Фонда «Сколково», а также ряд соглашений о реализации проекта организации в Обнинске производства инновационных материалов с участием средств регионального венчурного фонда. Опубликованные в прессе данные подтверждают актуальность для всей России поднятых на форуме вопросов. В большинстве Российских регионов подобные «наукоградные» центры и венчурные фонды не сформированы и соответствующие вопросы пока ещё далеки от разрешения. Этот вывод подтверждают данные Фонда«Петербургская политика», Российской академии народного хозяйства и госслужбы при президенте РФ и газеты«РБК daily», опубликовавших в июле 2011 года четвертый инновационный рейтинг регионов России ${ }^{136}$. Первое место в рейтинге занял Санкт-Петербург. Среди плюсов второй столицы оказались подписание договора о намерениях построить первый в стране центр протонной лучевой терапии, соглашение о сотрудничестве с компанией Билла Гейтса-Microsoft.

Институт статистических исследований и экономики знаний НИУ ВШЭ 29 июня 2016 года представил четвертый выпуск рейтинга инновационного развития

${ }^{135}$ Отчет о проведении мероприятия II Обнинский Инновационный Форум «Инновации для жизни. Системы инновационного развития» в Обнинске. Пресс-релиз.[Электронный ресурс].-Режим доступа: http://v3.marchmont.ru/conferences/Obninsk-2011/ 19-20 мая 2011 года.

${ }^{136}$ [Электронный ресурс].-Режим доступа:http://www.airko.org/ news/novosti-agentstva/ news3rdplace. 
субъектов Российской Федерации на пресс-конференции в ТАСС, прошедшей в формате телемоста Москва - Казань - Санкт-Петербург. Новый рейтинг возглавил Татарстан. Как утверждает источник, Москва потеряла первенство, впервые с 2008 года ${ }^{137}$.

Принимая во внимание необходимость подготовительного этапа, который требует существенных затрат времени и финансов в условиях затянувшихся экономических санкций стран Евросоюза против Российской экономики, эффективное функционирование кластеров медицинских инноваций в большинстве Российских регионов не носит прорывного характера. Пример тому созданный при содействии Фонда «Сколково» в 2011 году Калужский кластер инновационной биофармацевтики «Парк активных молекул».Лишь спустя пять лет министерство экономического развития, региональные власти и некоммерческие научные организации региона при содействии Фонда «Sk»смогли сформировать биомедицинский фармацевтический кластер мирового уровня. Калужский фармацевтический кластер вошел в число кластеров-лидеров инвестиционной привлекательности став победителем конкурса в октябре 2016г в рамках приоритетного проекта Минэкономразвития России. Исполнительный директор некоммерческого партнерства «Калужский фармацевтический кластер» Ирина Новикова отметила: «Данный успех стал возможным благодаря профессионализму и слаженной работе команды региона по подготовке и презентации заявки кластера, активной заинтересованности и поддержке Министерства экономического развития Калужской области, руководителей ведущих предприятий кластера и научных организаций

${ }^{137} \mathrm{~B}$ рейтинге инновационного развития регионов сменился лидер.URL доступ: http://cluster.hse.ru/news/2161/. 
региона» ${ }^{138}$. Данный факт подчеркивает трудности развития кластеров биомедицинского и фармацевтического профиля в структуре сформированных региональных центров кластерного развития при поддержке фонда «Sk».

В связи с медленным формированием кластеров медицинских инноваций в ГД РФ достаточно продолжительно с 2010г обсуждается вопрос инновационных предприятий, дублирующих недостаточно эффективные медицинские кластеры, способные решать вопросы внедрения и реализации интеллектуальной собственности в экономику страны. По мнению заместителя председателя Комитета ГД РФ по энергетике Ивана Грачева, высказанному в марте 2010 года в интервью Российской газете ${ }^{139}$ «... существует два основных варианта вложение денег в инновации. Первый путь через вложения бюджета, например, в «Роснано» и второй - через предоставление налоговых преференций инновационным предприятиям».

Партийный блок «Единая Россия» настаивал на том, чтобы вложения осуществлялись через бюджет. Данное предложение, по мнению Ивана Грачева, экономически недостаточно эффективно, так как вероятность найти правильный проект рыночной реализации знаний невысока, а рыночную стоимость знаний объективно оценить и, соответственно, профинансировать чрезвычайно трудно. При этом только один из десяти проектов, поддержанных бюджетом, может быть действительно инновационным и успешным. Блок «Справедливая Россия» ставил во главу

${ }^{138}$ Калужский фармацевтический кластер вошел в число кластеров-лидеров инвестиционной привлекательности мирового уровня став победителем конкурса в рамках приоритетного проекта Минэкономразвития России. Публикация на сайте Российской кластерной обсерватории 20.10.2016. URL доступ: http://cluster.hse. $\mathrm{ru} /$ news/2256/.

${ }^{139}$ Когда знания-деньги. М. Барщевский. Российская газета-WWW.RG.RU-4 марта 2010, №45 (5124).C8. 
угла налоговые преференции для инновационных предприятий, успешность функционирования которых носит далеко не массовый характер. При этом Государственной Думой РФ окончательно не был рассмотрен вопрос налоговых преференции для различных лиц использующих патентные изобретения. В обсуждаемом законе было недостаточно фиксировано представление инновационного предприятия как предприятия реализующего инновационные патентные технологии. При этом использование патента в технологическом процессе, с учетом сложившейся деятельности предприятия, могло и не проводиться. Для предприятия главным было приобретение статуса инновационного с получением налоговых преференций. В связи с этим возникла необходимость формализации определения инновационной деятельности. Определение инновационного предприятия, в частности, должно было включать действующий патент с патенто-доминирующей производственной деятельностью. В свое время «Единая Россия» отложила рассмотрение этого закона. По мнению бывшего заместителя председателя Гд РФ Ивана Грачева в течение многих лет законопроект об «инновационной деятельности» блока «Справедливой России» не выносился на обсуждение, и никаких конкурирующих законов не было принято.

Развитие механизмов внедрения различных форм государственно-частного партнерства в здравоохранение, связанных с развитием лизинговых форм отношений в здравоохранении оказалось также недостаточно эффективно. Как правило, лизингодатель-представитель государственно-частного бизнеса, за счет собственных и федерально-заемных средств приобретает не потребляемые вещи, такие как оборудование, средства транспорта, технологии и передает их в финансовую аренду лизинго-получателю. Вопрос интеграции и взаимодействия всех составляющих лизинга, регулируемого нормами ГК РФ, 
Федеральным законом “О финансовой аренде (лизинге)” и договорными условиями, требует хорошо отлаженного взаимодействия законодательной и исполнительной ветвей власти на региональном уровне. В противном случае процесс оказывается экономически неэффективным.

Экономически нецелесообразной формой лизинга государственно-муниципального партнерства является пример инвестирования в 2009 году комитетом здравоохранения областной администрации г.Волгограда в субъект здравоохранения Волгоградской области МУЗ Палласовскую ЦРБ медицинского оборудования стоимостью 65,4 млн. руб. ${ }^{140}$, которая не смогла в течение полутора лет его эффективно реализовать. По государственному контракту внутренней финансовой аренды (лизингу) комитет здравоохранения Волгоградской области оснастил МУЗ Палласовская ЦРБ сверхсовременным томографом «Hitachi»c выплатой денег по лизинговой схеме. При этом дополнительно к стоимости томографа комитет области по здравоохранению заплатил 14 миллионов рублей на его освоение. Лизинг в течение полтора лет был финансово не выгодным и экономически затратным. Реальные экономические потери из федерального бюджета за период простоя «лизингового» оборудования администрацией области не оценивались. Доступность дорогостоящей медицинской помощи в субъекте области не анализировалась, права пациентов оказались ущемленными, финансовые средства оказались неэффективно освоенными.

Существует также госбюджетный путь медицинских инноваций через программу модернизации здравоохранения и национальный проект- Федеральную программу «Здоровье».Однако при реализации программ модернизации здравоохранения и ПНП-приоритетного национального проекта «Здоровье», качество ремонтно-строительных

${ }^{140}$ Нездоровые расходы. Захаров. А. Газета городские вести. Царицын-Сталинград-Волгоград, декабрь 2009, №143.С.10. 
работ и федеральных лизинговых поставок в регионы высокотехнологичного оборудования вызвали справедливую критику.

По данным начальника управления по контролю за расследованием преступлений коррупционной направленности Следственного Комитета России (СКР) Владимира Макаровав2011 году были привлечены к уголовной ответственности 362 работника министерства здравоохранения и социального развития. Среди них врачи, привлеченные за выдачу больничных за вознаграждение, руководители и высокопоставленные чиновники, отвечающие за поставки медоборудования ${ }^{141}$ по программе модернизации системы здравоохранения. В частности Генеральная прокуратура в середине 2010 года завела уголовное дело по статье «Халатность» в отношении руководства Волгоградского областного клинического онкодиспансера ${ }^{142}$. Медтехнику в онкодиспенсер стоимостью 465,5млн. руб. поставили в 2009 году. Сначала несколько раз переносились торги, затем был затяжной поиск поставщиков и длительная подготовка к ремонту помещений под новое радиологическое оборудование. В это время выяснилось, что отсутствуют деньги на оформление проектно-технической документации, а поставленное оборудование некуда устанавливать ${ }^{143}$. Генпрокуратура насчитала много миллиардные убытки и возбудила по ним уголовные дела. Многоуровневые программные комплексы хранились в коридорах диспансера в течение 2-х лет. В результате пропускная способность медучреждения

${ }^{141}$ Самые коррумпированные сферы государства.[Электронный peсурс].-Режим доступа:http://vz.ru/news/2012/6/21/584803.html./

${ }^{142}$ Первая Газета 21.08.2010. [Электронный ресурс].-Режим доступа: http://www/pro-volgograd/ru/news/id/2274.

${ }^{143}$ Е.Акимова. Скандал в Волгоградском онкодиспансере: могли спасти жизни, но не нашли места для уникального оборудования». Газета Комсомольская правда. 05.07.11. [Электронный ресурс].-Режим доступа: http://Kp.ru./online/news/927447. 
по оказанию специализированной онкологической помощи снизилась на 40\%. В середине 2011 года, заместитель прокурора региона утвердил обвинительное заключение в отношении главного врача онкодиспансера и возбуждённое по ч.1 ст. 293 УК РФ (халатность) уголовное дело прокуратура направила в суд. Этим перечень финансовых потерь и ухудшения качества оказания медицинской помощи в областном Волгоградском онкологическом диспансере не ограничился. 7 января 2013 года центральный суд Волгограда санкционировал арест заместителя председателя Волгоградского областного правительства Павла Крупнова. По данным следствия, он курировал вопросы деятельности Министерства здравоохранения Волгоградской области, в том числе контролировал эффективность реализации программы модернизации здравоохранения в 2011-2012 годы. Одним из приоритетных мероприятий программы являлось проведение до 31 октября 2012 года капитального ремонта здания областного онкологического диспансера. По данным следствия, чиновник получил личную выгоду в 17 млн. рублей с проведения конкурса на право выполнения работ по капитальному ремонту здания областного онкологического диспансера. Задержанному было инкриминировано совершение преступления, предусмотренное частью 6 статьи 290 УК РФ («получение взятки в особо крупном размере») ${ }^{144}$. В начале 2013 года ремонтные работы в онкодиспансере не были закончены, условия и качество оказания специализированной онкологической медицинской помощи пациентам целого региона ухудшились ${ }^{145}$.

${ }^{144}$ Взят под арест пойманный на взятке волгоградский вице-премьер.[Электронный ресурс].-Режим доступа: http://www.infox.ru/ accident/crime/2013/01/07/Vzyat_pod_aryest_poy.phtml.

${ }^{145} \mathrm{~B}$ Волгоградской области арестован высокопоставленный чиновник, подозреваемый в получении многомиллионной взятки. [Электронный ресурс].-Режим доступа: http: //www.sledcom.ru/ actual/274262/ 07.01.2013. 
Методики работы в созданных в последнее время в России регионарных кардиологических центров на импортном высокотехнологичном оборудовании дороги и мало доступны из-за низких доходов широких слоев населения, поэтому недостаточно востребованы и не окупаются быстро. При анализе структуры госзаданий на высоко технологичную медицинскую помощь (ВМП) в разрезе территорий отмечалась существенная неравномерность распределения, дополнительно ограничивающая доступность ВМП по регионам страны. Основная доля госзадания по любому из показателей (числу больных, объемам финансирования) приходилась на Москву,Санкт-Петербург и отчасти на Сибирский федеральный регион. В 2008 году 36 субъектов Федерации вообще не участвовало в выполнении федерального госзадания по ВМП ${ }^{146}$.

Проблема внедрения медицинских инноваций актуальна и для новых лекарственных средств. В конце 2009 года в интервью Российской газете министра промышленности и торговли России Виктора Христенко последний отметил перспективу существенного снижения цен на лекарства. В частности для борьбы с высокими ценами на лекарства правительство РФ планировало использовать два инструмента. С одной стороны-ужесточить контроль за ценами. С другой-предпринять усилия для развития собственной фарминдустрии. Общий объем инвестиций до 2020 года оценивался в 177 миллиардов рублей, из которых часть профинансирована государством ${ }^{147}$. Предполагается, что государство закроет дыры в научно-исследовательских бюджетах при разработке новых лекарств.

${ }^{146}$ Рыбальченко И.Е.Территориальные аспекты формирования государственных заданий на оказание высокотехнологичной медицинской помощи. Ж.Менеджер здравоохранения.2009-.№2-С.16-23.

${ }^{147}$ Всех вылечим./ Зыкова. Т./ Российская газета. 2009.№249(5073).-С.6. 
Последнее время правительством начата проработка вопросов, которые позволят использовать на ранних стадиях испытаний, как бюджетные средства, так и средства Российской венчурной компании, компании «Роснано», Внешэкономбанка и других институтов развития главным образом для того, чтобы разделить риски связанные с инвестированием в фармтехнологии. Возможность включения в государственные инвестиционные проекты по созданию новых лекарств небольших фармацевтических компаний в России практически отсутствует. Несмотря на то, что малому бизнесу по силам оригинальные разработки в биотехнологическом секторе. Известны случаи их удачной реализации малыми предприятиями на рынке только за пределами России. Российские разработки уходят за границу и становятся собственностью западных компаний, повышая их конкурентоспособность.

В РФ практически отсутствуют инвестиционные компании и венчурные фонды, работающие с владельцами и авторами объектов интеллектуальной собственности. Однако уже много лет обосновались и работают на российском рынке зарубежные инвесторы, которые успешно уводят из России наиболее конкурентоспособные объекты интеллектуальной собственности. Примером являются интернет сайты: http://us-patent.info патентных услуг США-uspto и РСТ (патентные услуги по всем видам патентов) и сайт компании «Milgrom\&Associates» Валерия Мильгрома ${ }^{148}$, много лет предоставляющих услуги патентного поиска, патентования, коммерциализации в США объектов интеллектуальной собственности российских изобретателей. Консультативная интернет услуга адвоката компании «Milgrom\&Associates»для принятия стартовых решений оценивается минимум в $\$ 300$ США. При

${ }^{148}$ Американский патент для россиян.[Электронный ресурс].-Режим доступа:http://usa-patent.ru/about/work/index.html. Датаобращения 05.11.12. 
этом изобретатель осуществляет 100\% предоплату всех государственных пошлин США. Как указывает сайт, компания с удовольствием гарантировала бы и результат, но, к сожалению, он зависит не только от неё, но и от чиновников разнообразных американских государственных служб. Именно по этой причине компания никогда не гарантирует результатов своей деятельности, но требует, чтобы её труд был оплачен независимо от конечного результата. Единственным исключением является процедура коммерциализации изобретения, при условии, что изобретение стоящее и с изобретателем достигнута договоренность об условиях участия компании в доле от коммерциализации изобретения. Таким образом, наиболее стоящие российские изобретения коммерциализируются бизнесом США без существенных финансово-экономических бизнес вложений на этапах их разработки и патентования.

Почему же США сегодня притягивает одаренных людей, обладающих уникальными знаниями, способных создавать принципиально новое? Ответ не прост, и состоит он из нескольких взаимосвязанных частей. Во-первых, поддержку новаторских идей обеспечивает государство. И в первую очередь, на законодательном уровне. Интеллектуальная собственность США законодательно защищена за её пределами. Во-вторых, мощная господдержка и обеспечение прав владельцев интеллектуальной собственности не только привлекает изобретателей со всего мира, но и даёт уверенность потенциальным инвесторам безбоязненно вкладывать свои средства в перспективные разработки интеллектуальной собственности. Таким образом, обеспечивая финансовую выгоду инвесторам.

Известны трудности патентования в России и за её пределами объектов интеллектуальной собственности в медицинской и сопряженных с ней фармацевтической и биотехнологической областях, в которых процессы исследования и разработки требуют значительных инвестиций 
на весьма продолжительное время. Данные особенности патентования для инвесторов и потенциальных пользователей медицинских инноваций в России представляются областями высокого риска, так как в период до получения прибыли на рынке изобретений возможно появление новых конкурентно способных видов аналогичной продукции.

Из-за отсутствия средств, включая валютные, на патентование изобретений за границей, российские разработчики в медицинской и сопряженных с ней областях, патентуют свои изобретения в основном только в России, что создает возможность безвозмездного копирования и реализации их изобретений в других странах ${ }^{149}$. В работе $\mathrm{V}$ съезда Всероссийского общества изобретателей и рационализаторов в июле 2012 года внимание участников было особо обращено на высокий уровень патентования за последние 5 лет в России зарубежных изобретений на фоне снижения активности российских заявителей ${ }^{150}$.

Выйти на международный рынок интеллектуальной собственности российским изобретателям не просто. Прежде всего, это недешево. Так, за европатент необходимо выложить 25 тыс. €, в США патентование стоит \$18 тыс., в Японии- \$15 тыс. Ко всему прочему необходима оплата государственных пошлин и услуг патентных поверенных в валюте. Очевидно, что без помощи государства, банковского сектора, венчурного капитала, прорыва тут ожидать неоткуда. Поэтому Россия с 2010года закупает лицензий больше, чем продаёт ${ }^{151}$.

${ }^{149}$ Вакуленко И.М. «В чем особенности правовой защиты изобретений в области медицины?». Ж.Патенты и лицензии. 2008.,№12.,С.45-48.

${ }^{150}$ Изобретателям нужна поддержка государства. Ж.Патенты и лицензии.Интеллектуальные права. №9.,2012.,С.42.

${ }^{151}$ Гурвич В. «Баланс перевернулся.Сегодня Россия покупает больше лицензий, чем продаёт».Российская Бизнес-газета №748 от 4 мая 2010г.[Электронный ресурс].-Режим доступа htpp//www.rg.ru/ gazeta/biznes/2010/05/04.html 
В реальности всегда существует разрыв между достижениями фундаментальной науки и внедренными в клиническую практику инновациями. Свободно циркулируемые и общественно значимые знания фундаментальной науки после выведения из научного оборота и коммерциализации снова вводятся в открытый, но уже торговый оборот зарубежными транснациональными компаниями в рамках TRIPS-торгово-связанных аспектов защиты прав интеллектуальной собственности, что ограничивает её доступность, в том числе для самих разработчиков. Вместе с тем существуют трудности переноса новых медицинских технологий из лабораторий в клинические исследования ив широкую медицинскую практику. Наметившийся во второй половине XX века многообещающий прогресс медицинской науки, по оценкам американского FDA (Федеральное управление по контролю за пищевыми продуктами и лекарственными средствами), начиная с последнего десятилетия XX века претерпевает существенное замедление. Несмотря на 2-кратноеувеличение финансирования биомедицинских исследований в США, направленных на создание новых лекарственных средств за период с 1993 по 2003 годы, с 2000 года сформировалась устойчивая тенденция снижения количества новых лекарственных средств, ежегодно выходящих на медицинский рынок. Продолжает расти разрыв между достижениями фундаментальной науки и внедренными в клиническую практику инновациями, проявляющийся 2 «трансляционными блоками»: 1-й блок затрудняет перенос новых медицинских технологий из лабораторий в клинические исследования, 2-й-перенос результатов клинических исследований в широкую медицинскую практику. 152

По оценкам представителей исследовательского сообщества и регуляторных органов США указанные

${ }^{152} 1$ Sung N.S., Crowley W.F. Jr., Genel M. et al. Central challenges facing the national clinical research enterprise. // JAMA. 2003. Mar. 12; 289(10). P. 1278-1287. 
трансляционные блоки служат проявлением таких проблем, как рост стоимости клинических исследований, сочетающийся с недостаточным их финансированием, низкая эффективность клинических исследований, выражающаяся в больших затратах времени и неудовлетворительной результативности, громоздкие механизмы регулирования клинических исследований, несовместимость баз данных, недостаточное число квалифицированных исследователей и подходящих пациентов, желающих стать участниками клинических исследований.

Кроме этого, существует проблема клинических исследований и внедрения новых способов применения уже известных ЛС, являющихся объектами патентного права, используемых по новому назначению, производстве новых композиций и в реализации новых технологий. По данным российских аналитиков существенных позитивных результатов система здравоохранения в 2009-2010гг. не достигла. Несмотря на позитивную направленность федеральных законов не были решены ключевые проблемы здравоохранения. Среди них: недофинансирование из общественных источников минимум в 1,6 раза; дефицит, неоптимальная структура и неудовлетворительная квалификация медицинских кадров; устаревшие нормативы программы государственных гарантий бесплатной медпомощи, в том числе недостаточное обеспечения лекарственными средствами населения в амбулаторных условиях; свёртывание мощностей производственной медицины, а также её неэффективное управление ${ }^{153}$.

Таким образом, анализ итогов основных направлений развития российской медицины и её инновационных технологий последнего десятилетия позволяет сделать следующие выводы:

153Улумбеков Г.Э. Здравоохранение России: итоги 2010г. Что надо делать дальше?/Ж.Менеджер здравоохранения 2011,№3.С.6-20. 
1) Экономические и финансово-законодательные условия для успешной реализации инновационных объектов патентного права лечебно-диагностических методов, аппаратуры и лекарственных препаратов в России окончательно не сформировались и на рынке постоянно изменяются;

2) Поддержка изобретателей и их изобретений со стороны государственных и муниципальных органов власти не осуществляется;

3) Финансово-инвестиционные риски и налоговые преференции для патентования объектов интеллектуальной собственности в медицинской и сопряженных с ней областях (фармацевтической и биотехнологической) в России не решены на государственном уровне;

4) Разрешения на использование вновь регистрируемых медицинских технологий, являющихся объектами интеллектуальной собственности, излишне затянуты, не оптимизированы сроки их рассмотрения в надзорных государственных органах;

5) Интерес к отечественным инновационным объектам патентного права (ОПП) в сфере медицины за пределами России высокий, правовая защита российских ОПП за её пределами низкая;

6) Поставки высокотехнологичного медицинского оборудования по федеральным проектам и муниципальному лизингу затратные, экономически недостаточно эффективные, не окупаются быстро;

7) Дорогостоящая высокотехнологичная медпомощь, оказываемая в крупных медицинских центрах на импортном оборудовании недостаточно квотирована и доступна из-за низких доходов широких слоев населения;

8) Государственные инвестиции в «наукоградые» регионы РФ не решают проблем коммерциализации не «наукоградных» патентных инноваций медицинских технологий; 
9) Для инвестиций в российскую медицину не создана благоприятная законодательная и инвестиционно-налоговая политика;

10) Недостаточной эффективности инвестиций в здравоохранение России способствуют: недофинансирование из государственно-бюджетных источников; дефицит, неоптимальная структура и неудовлетворительная квалификация медицинских кадров; устаревшие нормативы программы государственных гарантий бесплатной медпомощи; недостаточное обеспечения лекарственными средствами населения в амбулаторных условиях; недостаточно неэффективное управление мощностями производственной медициныи нередко их свёртывание в рамках модернизации.

11) Существующие сложности в коммерциализации медицинских инноваций усугубляет отсутствие интереса российских инвесторов к медицинским изобретениям, недостаток коммуникационной налаженности между изобретателями и инвесторами капитала. 


\section{4.Проблемы инвестиций в медицинские технологии России}

По мнению 46\% участников опроса 2011 года фонда общественного мнения ФОМ-2011 в России сложилось плохая ситуация с разработкой и внедрением инноваций (Диаграмма.1.)Среди людей, принимавших участие в опросе и разбирающихся в вопросах инноваций, доля подобных ответов составила $56 \%$.

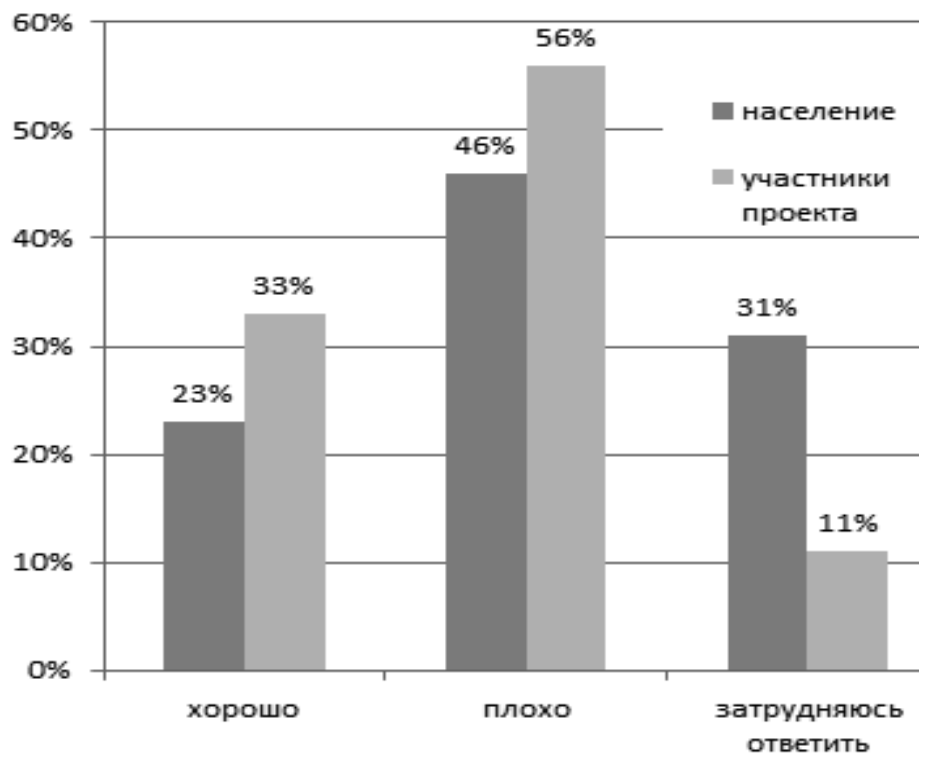

Диаграмма 1. Результаты интервью по вопросу «Как, на ваш взгляд, обстоят дела с разработкой и внедрением инноваций в Россиихорошо или плохо?» (Результаты исследования ФОМ-2011).

Большинство лиц опрошенных в исследовании ФОМ-2011 выделили модернизацию и технологическое обновление в области промышленности и сельского хозяйства в качестве первоочередной задачи. Необходимость 
аналогичных мер в здравоохранении отметили 17\%, в образовании $13 \%$ участников опроса (Диаграмма. 2).

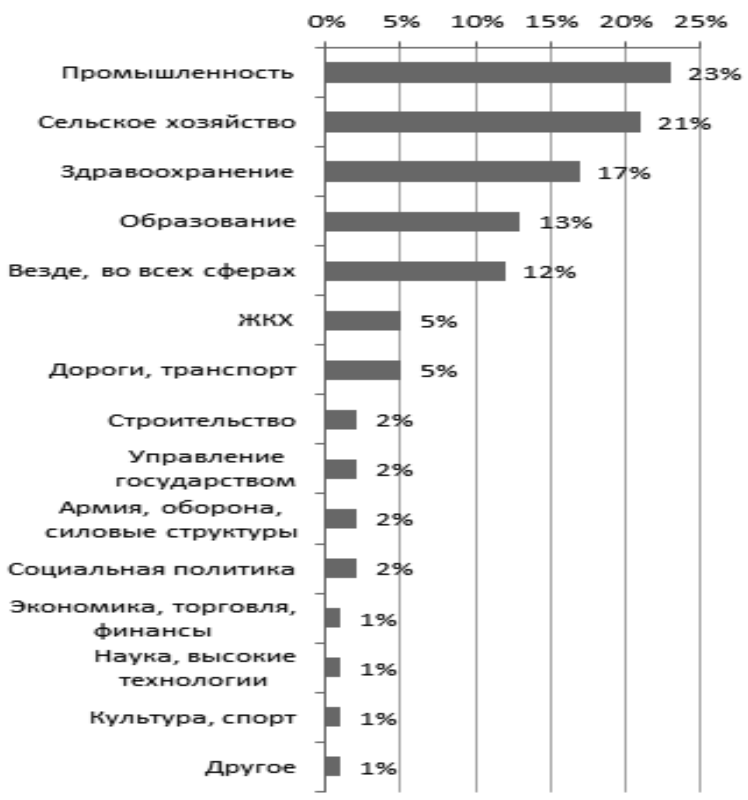

Диаграмма 2. Результаты интервью по вопросу. «Где, в каких сферах, по вашему мнению, в России требуется модернизация и технологическое обновление первую очередь?» (Исследование ФОМ-2011).

По вопросу инноваций 69\% участников опроса ФОМ-2011считало, что государство должно поощрять и стимулировать процесс инноваций (диаграмма 3.). 64\% считало, что инноваций должны распространяться как можно шире. 


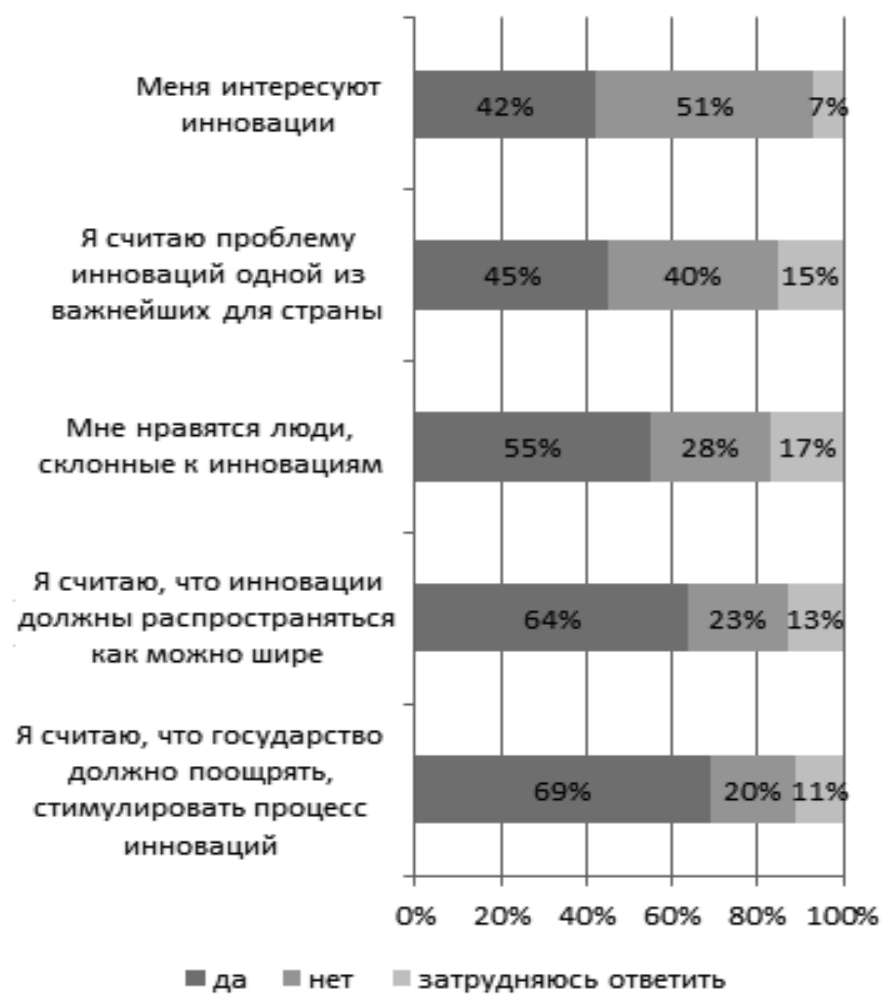

Диаграмма 3. Результаты исследования ФОМ-2011 по вопросу инноваций. ${ }^{154}$

Больше половины (64\%)участников исследования ФОМ-2011 полагают, что инновации следует распространять как можно шире, $45 \%$ опрошенных отметили проблему инноваций в качестве одной из важнейших для страны.

${ }^{154} \mathrm{O}$ смысле инноваций. Коллективная книга: обсуждение, подготовка, создание. [Электронный ресурс].- Режим доступа: http:// innov.fom.ru/book/node/complex/177. Дата обращения 05.01.2013. 
При этом 30\% участников интервью выделили в качестве первоочередной проблемы - проблему модернизации здравоохранения и образования (17\% и $13 \%$, соответственно). В ходе опроса 1511 человек в возрасте 18 лет и старше на тему «отношение россиян к медицине»в декабре 2011 года сотрудниками Левада-Центра в рамках международной программы социальных исследований (International Social Survey Programme, ISSP)среди 91\% участников опроса установлена необходимость изменений в системе здравоохранения. Положительный ответ на вопрос «требует полного изменения система здравоохранения» дали $26 \%$ интервьюированных, «требует больших изменений»- 45\% и «требует небольших изменений» -20\%. Лишь четыре процента считали, что изменения не требуются, оставшиеся пять процентов затруднились ответить ${ }^{155}$. Неэффективной систему здравоохранения признали $53 \%$ россиян; отчасти согласны, отчасти не были согласны с этим утверждением $24 \%$ и лишь 17\% считали ее эффективной. Улучшений в течение нескольких последующих лет ожидало лишь 29\% опрошенных, не ожидало 34\% процента, 27\% процентов ответили «отчасти да, отчасти нет». При этом более высокие налоги для улучшения медобслуживания населения в целом готовы платить только 16\% процентов опрошенных, $64 \%$ не готовы, и 13\% не определились. В рамках проведенного исследования ISSP полное доверие российской системе здравоохранения высказали всего лишь 6\%, еще $18 \%$ опрошенных ответили «по большей мере доверяю». Только 10\% считают, что в России можно доверять врачам. 63\% считают, что люди страдают от серьезных заболеваний, потому что сами наносят вред своему здоровью. 16\%

15591 процент россиян хотят перемен в здравоохранении.04.02.12.[Электронныйресурс].- Режимдоступа: http://www. univadis.ru/medical_and_more /Local_Medical_News_Detail?link=/RU/ Local_Medical_News/Novosti-rossijskogo-zdravoohraneniya/(language)/ rus-RU\&id=468493 
отметили, что решить проблемы со здоровьем нетрадиционная медицина помогает лучше, чем официальная.

Таким образом, по данным социологического исследования ISSP лишь 10\% опрошенных доверяют врачам, 16\% считают нетрадиционную медицину более эффективной в сравнении с официальной, более 75 \% участников не готовы платить более высокие налоги для улучшения медобслуживания. Улучшений в течение нескольких последующих лет в системе здравоохранения ожидают менее трети опрошенных.Вероятно, поэтому больше половины (64\%) участников другого социологического исследования ФОМ-2011 предлагают более широкое распространение инноваций. При этом 17\% участников ФОМ-2011 выделили в качестве первоочередной проблему модернизации здравоохранения ${ }^{156}$ Приведённые данные социологических исследований в РФ в целом свидетельствуют о кризисном положении в российской медицине и минимальном доверии населения к ней.

На нынешнем этапе развития различные сферы российской экономики развиты по-разному, от высоко технологичных и экономически рентабельных до нецелесообразных и убыточных. Одним из важных условий успеха модернизации различных социально-экономических сфер страны является хорошо продуманное законодательно эффективное применение инструмента государственного стимулирования инновационной деятельности через предоставление льготированного порядка налогообложения затрат, связанных с фондом оплаты труда (в части льготирование взносов на социальные отчисления) и по научно-исследовательским работам. До сих пор ФЗ N 212-ФЗ от 24.07.2009 г., регулирующий порядок исчисления страховых взносов, не предусматривает льгот для компаний,

${ }^{156}$ Россияне мало доверяют врачам. [Электронный ресурс].Режим доступа: http://narmed.ru/articles/news/rossiyane_malo_ doveryajut_vracham. 
осуществляющих инновационную деятельность ${ }^{157}$. С учётом увеличения суммарного страхового тарифа на инновационные компании до 34\% с 2011 года, доля расходов на оплату труда составляет 70-80\% от дохода. Малый бизнес пользуется в России двумя специальными налоговыми режимами: упрощённой системой налогообложения и единым налогом на вменённый доход для отдельных видов деятельности, которые мало способствуют инновациям. С 2013 года в Налоговом кодексе России появилась новая глава под названием «патентная система налогообложения».

Согласно патентной системы налогообложения индивидуальные предприниматели могут получить патент на оказание услуг и при этом будут избавлены от подоходного налога, налогов на имущество и добавочную стоимость. Утверждается, что данная система может не только значительно снизить трудозатраты на ведение бухгалтерии, но и способствовать легализации некоторых видов деятельности, появлению новых малых предприятий, включая инвестиционные. Патентная система налогообложения уменьшает объём бюрократических процедур у индивидуальных предпринимателей, так как сумма за патент устанавливается фиксировано. В тоже время стоимость патента каждый регион устанавливает самостоятельно. По инициативе петербургских законодателей на обсуждение внесена стоимость патента 25-50 тыс. рублей. В других регионах сумма может быть другой. Установленную законодателями сумму за патент надо заплатить вперёд даже в случае нулевого заработка ${ }^{158}$. Систему

${ }^{157}$ Нина Гулис. Стимул для новаторов. Как получить налоговые льготы по НИОКР «Российская Бизнес-газета»№762(29).10 августа 2010 г. [Электронный ресурс].-Режим доступа: htpp://www.rg.ru// 2010/08/10/ gulis.html.

158 Ливнева Л. Патентная система налогообложения вам в помощь. «Информагенство Волга» г.Волгоград. Газета «Областные вести в каждый дом». 2013.,№14.С.2. 
патентного налогообложения, меняющуюся географически независимо от получения прибыли, стабильной и выгодной для разработчиков инноваций и представителей малого бизнеса не назовешь. На этом фоне реально предсказуемо снижение и сокращение инновационной деятельности физических и юридических субъектов занятых в малом и среднем бизнесе. Данный вывод согласуется с результатами исследований зарубежных аудиторских компаний в России и подтверждён динамикой снижения капитальных вложений в науку в Волгоградском регионе в 2007-17гг, с одновременным снижением патентной активности учёных и населения региона Волгограда в указанный период времени.

По данным восьмого 2012года исследования 1000 бизнесменов из всех секторов экономики России, выполненного аудиторской компанией Ernst\&Young, 65\% опрошенных отметили нейтральное влияние налогового режима на приток инвестиций, ещё 30\% оценили его влияние как негативное. Аудиторская компания опросила представителей розничной торговли, тяжелой и легкой промышленности, финансовых услуг. 45\% опрошенных представляли российские компании, 55\% - иностранные, работающие в России.

Публичные и частные компании в исследовании были представлены поровну ив основном применяли стандарты международной отчётности. В отличии от 2012г, в 2010г-2011г 50\% респондентов отмечали негативное влияние налогового режима на приток инвестиций, ещё $36 \%$ считало его влияние нейтральным ${ }^{159}$. Несмотря на существенные налоговые издержки в целом «наблюдается позитивная тенденция улучшения отношения респондентов к налоговому режиму», отметил Питер Рейндхардт,

${ }^{159}$ Орлова Ю. Бизнес освобождается от политики. Газета RU.[Электронный ресурс].-Режим доступа: http://www.gazeta.ru/ business/2013/01/30/4946869.shtml 
партнер E\&Y, представивший данное исследование. Косвенно эти результаты подтверждает рейтинг 2013г Doing Business Всемирного банка, в котором Россия по «уплате налогов» поднялась до 63-го места (занимала 102-е место в рейтинге предыдущего года), обогнав США, которые занимают 69-е место. Данный факт заметного роста уплаты налогов россиянами Питер Рейндхардт объяснил низкими налоговыми ставками для физических лиц в России в сравнении с другими странами. В целом, по его мнению, налоговая система России выступает одним из положительных факторов инвестиционного климата. По мнению опрошенных, за указанный период времени снизилось и влияние политических факторов на инвестиционный климат России. Конкретно речь идет об уменьшении влияния власти на решения налоговых органов и судов, которые часто действуют не интересах инновационных инвесторов, в частности, в вопросах налогов для разработчиков НИОКР и новых медицинских технологий.

Таким образом, по данным исследований в России аудиторской компании Ernst\&Young в 2012году, в сравнении с периодом 2010-2011гг, негативное влияние налогового режима на приток инвестиций уменьшилось до 36\%, но всё ещё оставалось достаточно высоким, с учётом в основном нейтрального характера влияния налогового режима. Это свидетельствовало о слабой государственной поддержке инвестиций бизнеса в экономические инновации России в данный период времени.

В обществе до сих пор идут активные обсуждения в отношении возможности предоставления льготного страхового тарифа компаниям из сферы интеллектуального труда (ИТ или IT), которые пользовались льготной шкалой ЕСН до 2009 года. Кроме того, в процессе согласования рассматривается расширение перечня возможных получателей льготы для организаций, занимающихся разработкой программного обеспечения для российского рынка. 
Для улучшения ситуации необходимо, чтобы востребованные IT сообществом поправки своевременно вносились Государственной Думой в законодательство РФ. В отношении затрат на НИОКР необходимо отметить, что хотя налоговым кодексом РФ предусмотрены существенные меры поддержки организаций осуществляющих НИОКР, в виде единовременного учета расходов на НИОКР не давших положительного результата, и возможности учета определенных расходов по НИОКР (в том числе, не давших положительного результата) в размере $150 \%$ (по перечню правительства РФ, установленного постановлением от 24.12.2008 N 988).Однако применение данных норм в практике НК РФ неоднозначно и потому вызывает множество вопросов. В частности, определение НИОКР, содержащееся в 262-й статье налогового кодекса (НК) РФ, является достаточно общим, что вызывает затруднения при определении правомерности отнесения понесенных расходов к расходам на НИОКР в понимании НК РФ. Более того, для определения соответствия НИОКР видам работ, указанным в перечне правительства РФ, в целях применения повышающего коэффициента, Министерство финансов РФ рекомендует обращаться в Министерство образования и науки РФ (письмо от 16.07.2009 N 03-0306/1/472). Это создаёт дополнительные бюрократические препятствия право применимости действующих налоговых льгот. Также остается не до конца решенным вопрос о порядке учета результатов НИОКР, в результате которых налогоплательщик получает исключительные права на результаты интеллектуальной деятельности. В соответствии с НК РФ такие результаты могут быть признаны нематериальным активом организации, и в случае невозможности определения срока полезного использования, позволяют амортизировать полученный нематериальный актив в течение 10 лет. В то время как расходы на НИОКР, не давшие положительного результата, могут быть учтены в составе 
расходов только однократно-единовременно.При этом не учитывается возможность учёта последующих расходов на дальнейшую разработку перспективных но не давших положительного результата НИОКР.

В план правительства РФ входит дальнейшее совершенствование порядка учета расходов на НИОКР путем конкретизации статей расходов, относимых к расходам на НИОКР, уточнение перечня в целях применения коэффициента 1,5 . Остается надеяться, что планируемые изменения сделают рассматриваемую норму налогового кодекса РФ более понятной, широко и легко применимой на практике. Совершенно очевидно, что требуется законодательное упрощение применения норм налогового стимулирования результатов НИОКР.

При введении новых инновационных медицинских технологий в хозяйственный оборот, часто являющихся объектами патентного права, неизбежно возникает вопрос регламентации медицинской деятельности хозяйствующих субъектов. При решении этого вопроса рекомендуется обращаться к корреспондирующим нормам множества законодательных и исполнительных актов таких, как Конституция РФ, Основы законодательства Российской Федерации об охране здоровья граждан (далее -Основы O3), Гражданский кодекс РФ (часть четвертая; далее ГК РФ), Закон РФ от 28.06.91 №1499-1 «О медицинском страховании граждан в Российской федерации», Федеральный закон от 12.04.10г № 61-Ф3 «Об обращении лекарственных средств», Федеральный закон от 23.08.1996 №127-Ф3 «О науке и государственной научно-технической политике», приказ Минздравсоцразвития России от 20.07.2007г №488 «Об утверждении Административного регламента Федеральной службы по надзору в сфере здравоохранения и социального развития по исполнению государственной функции по выдаче разрешений на применение новых медицинских технологий (далее-Приказ №488). 
Если рассматривать понятие «медицинская технология» в соответствии с п.1.3. Приказа №488 неизбежно возникает противоречие между определением «новой медицинской технологии» и регламентированной возможностью ее реализации. Так согласно выше приведенного приказа к новым медицинским технологиям относятся впервые предлагаемые к использованию на территории РФ или усовершенствованные совокупности методов, приёмов, способов лечения, диагностики, профилактики, реабилитации (далее-методы), с помощью которых данные методы осуществляются, а в некоторых случаях - и способ получения средства, применяемого в данной технологии. Методы, способы и средства, применяемые в новых медицинских технологиях, могут включать использование не новационных лекарственных средств и изделий медицинского назначения при условии, что они зарегистрированы в установленном порядке в Российской Федерации.

Процесс регистрации и порядок принятия решения уполномоченным органом - Росздравнадзором о выдаче разрешения на применение новой медицинской технологии бюрократично продолжителен (около 177 дней) и трудоёмок. До подачи документов в Росздравнадзор все изделия медицинского назначения предварительно подвергаются техническим, токсикологическим и иным видам испытаний, которые могут быть выполнены национальным испытательным институтом России -ФГУ «Всероссийский научно-исследовательский и испытательный институт медицинской техники» либо другой уполномоченной Росздравнадзором и аккредитованной испытательной лабораторией. В России под неодобрительный гул медицинского сообщества был принят №323-Ф3 «Об основах охраны здоровья граждан Российской Федерации», в котором определило множество «порядков», регламентирующих процессы экспертизы качества, оценки эффективности, безопасности медицинских изделий, их вывоз и 
ввоз на территорию РФ. Проект «Порядка государственной регистрации» данного закона в качестве обязательного устанавливает требование согласования документации «с испытательной организацией».В тоже время полномочия у испытательных организацией по установлению и утверждению требований к медицинским изделиям в 2012 году отсутствовали ${ }^{160}$. Не были установлены они и в проектах нормативно-правовых актов, разработанных в целях реализации статьи 38 №323-Ф3 «Об основах охраны здоровья граждан в РФ», включая проект «Об утверждении Порядка государственной регистрации медицинских изделий». Не достаточная разработанность данного положения - фактор лимитирующий оборот и применение инновационных лечебно-диагностических технологий, использующих новые медицинские изделия.

В российской правоприменительной практике существует порядок проведения доклинических и клинических исследований лекарственных средств, различных испытаний, которым подвергаются изделия медицинского назначения. Однако в целом, по отношению к медицинским технологиям, отсутствует нормативно-правовая база регламентирующая проведение биомедицинских исследований перед регистрацией медицинских технологий. В настоящее время в целях реализации №323-Ф3 «Об основах здоровья граждан в Российской Федерации» уполномоченный федеральный орган исполнительной власти разрабатывает множество трудно выполнимых«порядков», регламентирующих ввоз на территорию РФ и вывоз с неё медицинских изделий, проведение экспертизы качества, эффективности и безопасности медицинских изделий. По мнению некоторых авторитетных аудиторов Европейского общества по качеству (EOQ Quality Auditor) довольно сложная ситуация с техническим регулированием

${ }^{160}$ Солонников С. История реформы, или «туда и обратно». Ж.Ремедиум.2012.,№11.С.73-77. 
медицинских изделий в России прослеживается на всех этапах реформы технического регулирования, которая началась в 2002г и проводится крайне медленно, непоследовательно, непродуманно ${ }^{161}$.

За рубежом имеется опыт по оценке медицинских изделий и технологий, которую осуществляют различного рода агентства и общества. Например ISTAHC международное общество по оценке технологий здравоохранения (International Society of Technology Assessment in Health Care), организованное в 1985 году. Зарубежные организации такой направленности в настоящее время объединены в международную ассоциацию агентств по оценке медицинских технологий (INAHTA). Росздравнадзор с 2009года стал членом INAHTA и получил доступ к базе данных разрешенных к применению медицинских технологий в Европе. Это способствует внедрению в медицину РФ зарубежных патентных технологий, усиливает их конкурентную способность против российских не патентованных в ЕС технологий. На внутреннем рынке конкурентной способности российских инноваций в немалой степени препятствует недостаточная разработанность законодательно-правовой базы.

Согласно пункта 1.4 Приказа №488 заявление и документы для получения разрешения на применение новой медицинской технологии могут подаваться организацией разработчиком или автором медицинской технологии, либо иным лицом, действующим от имени заявителя по доверенности. Разрешение на применение медицинской технологии выдается от имени лица(лиц), осуществляющего(их) медицинскую деятельность на основании соответствующей лицензии и указываемого(ых) в заявлении на выдачу разрешения. Таким образом, автор изобретения или инновации по Приказу №488 предварительно должен

${ }^{161}$ Солонников С. История реформы, или «туда и обратно». Ж.Ремедиум.2012.,№11.С.73-77. 
иметь лицензию на медицинскую деятельность. При отсутствии последней, в случае работы автора(ов) в частном предпринимательском учреждении и ГУЗе, возникают проблемы с оформлением документов на разрешение. Разработчик и автор не владеющей лицензией на медицинскую деятельность не может сам реализовать своего права на использование инновации и должен предоставить возможность её реализации ГУЗу, сторонней российской или зарубежной венчурной компании.

Комплект документов в соответствии с п.3.3.3 Административного регламента должен содержать: заявление на получение разрешения на применение новой медицинской технологии; описание медицинской технологии, структура которого изложена в приложении к Административному регламенту; не менее двух утвержденных руководителем отзывов профильных научно-исследовательских или образовательных медицинских учреждений; протоколы и отчеты о результатах доклинических исследований, утвержденные в установленном порядке в случае, если они проводились; протоколы клинических исследований, если они проводились, утвержденные в установленном порядке; копия патента при его наличии; копия регистрационных удостоверений, санитарно-эпидемиологических заключений и иных разрешительных документов на лекарственные средства или изделия медицинского назначения, используемые в новой медицинской технологии; инструкции по применению лекарственного средства или изделия медицинского назначения, используемые в новой медицинской технологии; документы подтверждающие использование медицинской технологии за рубежом, если она там используется.

Обращает внимание на себя то, что в комплекте документов Административного регламента наличие патента на регистрируемую медицинскую инновацию не обязательно, хотя для бюджетов учреждений различного 
профиля здравоохранения экономически выгодно. Наличие же патента на изобретение не упрощает процедуры разрешения регламента на применение инновационной медицинской технологии. Описание медицинской технологии является обязательным элементом при выдаче патентов на изобретения. Использование описания к патенту на изобретение по медицинской технологии, прошедшее экспертную оценку ФИПС, пока не может быть принято в пакете регистрационных документов для ускорения разрешения применения. При принятии решения о выдаче патента на изобретение обязательно его соответствие требованиям статьи 1349 ГК РФ, где указаны объекты, на которые не могут быть предоставлены патентные права, включая решения противоречащие общественным интересам, принципам гуманности и морали. Возникает вопрос целесообразности требования Административным регламентом дополнительных документов при наличии патента ФИПС, отвечающего требованию практического применения изобретения по способу лечения и технологии получения изделия медицинского назначения. Получению разрешений на использование вновь регистрируемой медицинской инновации также препятствует отсутствие на текущий момент законодательно утверждённых требований, предъявляемых к медицинским изделиям для государственной регистрации, включая изделия медицинского назначения, используемые в регистрируемой медицинской технологии. В положении о Министерстве Здравоохранения, утверждённом ПП РФ от 19 июля 2012 г.№608, установлены полномочия по организации и проведению экспертизы качества, эффективности и безопасности медицинских изделий, а также по организации и проведению оценки соответствия государственной регистрации медицинских изделий. Полномочия же по установлению и утверждению требований к медицинским изделиям отсутствуют. 
Проект Постановления Правительства РФ «Об утверждении порядка государственной регистрации медицинских изделий» устанавливает для изделий соблюдение требований изготовителем того что, казалось бы, облегчает экспертизу. На самом деле противоречивость статуса испытательной организации, с которой изготовителю необходимо согласовать документацию на изделие, препятствует быстрому проведению экспертизы. Под испытательной организацией подразумевается уполномоченная Росздравнадзором и аккредитованная Росаккредитацией испытательная лаборатория. Последняя становится «соучастницей» проектирования и разработки медицинского изделия и поэтому может и должна лишаться статуса независимости вследствие неизбежности тесного контакта заявителя и аккредитованной лаборатории в вопросах согласования изделий. Одновременно подобный контакт заявителя с лабораторией «соучастницей» в принципе не допускается согласно ст. 26 №184-Ф3 «О техническом регулировании» в отношении обязательной сертификации: «Аккредитованные испытательные лаборатории (центры) проводят исследования (испытания) и измерения продукции в пределах своей области аккредитации. Органы по сертификации не вправе предоставлять аккредитованным испытательным лабораториям (центрам) сведения о заявителе».

Законодательно не урегулированные противоречивые положения статьи 26 №184-ФЗи ПП по регистрации новых российских медицинских технологий тормозят получение разрешений на их применение. В результате часть новых российских медицинских технологий реализуется зарубежными бизнес компаниями, которые спустя годы лицензионно поставляют их на Российский рынок по монопольно высоким ценам. В связи со сложившейся ситуацией Минздравом России в феврале 2013 года создан координационный совет по вопросам обращения 
лекарственных средств и изделий медицинского назначения. Данным советом рассмотрено более 150 поправок, представленных медицинскими и фармацевтическими ассоциациями, министерствами и ведомствами. Изменения были запланированы более чем в 40 статей действующего закона о лекарствах и изделиях медицинского назначения. Однако запланированные изменения не включали норм прямого действия. Их только планировалось проработать и принять в подзаконных нормативных актах ${ }^{162}$.

Мало что изменилось в вопросе разрешения новых медтехнологий с принятием N323-ФЗ.Несмотря на то, что в нормах вступившего в силу с 1января 2012 года Федерального закона N323-ФЗ»Об основах охраны здоровья граждан в Российской Федерации» от 21.11.2011 отсутствует полномочия федеральных органов государственной власти в сфере здравоохранения по выдаче разрешений на применение новых медицинских технологий. Согласно ПП РФ от 22.01.2007 N30 по-прежнему предусмотрено лицензионное требование о соблюдении лицензиатом медицинских технологий при осуществлении медицинской деятельности, разрешенных к применению в порядке, установленном законодательством РФ. По мнению Минздравсоцразвития России, до издания нового положения о лицензировании медицинской деятельности прежнее положение, утвержденное Постановлением Правительства РФ от 22.01.2007 N 30, может и должно применяться в части, не противоречащей действующему законодательству РФ.

Таким образом, с начала 2002 года в Российской федерации медленно реформируется нормативно-правовая

${ }^{162} \mathrm{~B}$ Минздраве России создан Координациннный совет по вопросам обращения лекарственных средств и изделий медицинского обращения.11.02.13. [Электронный ресурс].-Режим доступа: http: // www.univadis.ru/medical_and_more/Local_Medical_News_Detail?link=/ RU/Local_Medical_News/V-Minzdrave-Rossii-sozdan-Koordinacionnyjsovet-po-voprosam-obrascheniya-lekarstvennyh-sredstv-i-izdelijmedicinskogo-naznacheniya/(language)/rus-RU\&id=946811 
база по упорядочению процедур, документов, регламентирующих оборот новых медицинских препаратов, изделий и технологий, которая далеко несовершенна ${ }^{163}$. Очевидно, что жизненно необходимы дополнительные законодательные меры прямого, не декларативного характера, регламентирующие оборот, регистрацию и разрешение на применение патентных инновационных медицинских препаратов, изделий и технологий.

Вопросы упорядочения регламента введения в хозяйственный оборот новых изделий инновационных технологий медицинского назначения приобретают особую актуальность в связи с морально устаревшей с 2006г диагностической базой во многих учреждениях здравоохранения. На заседаниях Комиссии по исполнению приоритетного национального проекта «Здоровье» 21-22 июня 2006 года обсуждался вопрос слабой и устаревающей диагностической базы в большинстве амбулаторно-поликлинических учреждений России, указывалась необходимость скорейшего оснащения первичного звена новым диагностическим оборудованием. Кроме того, было отмечено, что имеет место невозможность оказания специализированной помощи и внедрения современных технологий по целому ряду кадровых и управленческих причин. В частности отмечалось отсутствие новой модели кадровой работы, обеспечивающей подготовку кадров с постоянным повышением их квалификации для внедрения и использования новых медицинских технологий.

Эксперты комиссии по исполнению нацпроекта выразили единодушное мнение о недостаточности выделенных в рамках национального проекта средств для замены устаревшего оборудования. В связи с этим комиссией было принято решение предусмотреть с 2007 года полное

${ }^{163}$ Коваленко Т.Н., Волокитина Е.А. Правовые аспекты новых медицинских технологий. Ж.Правовые вопросы в здравоохранении.№1.2010г. С.10-19. 
покрытие высокотехнологичной (дорогостоящей) помощи в стране за счет федерального и регионального бюджетов. При этом в 2008 году было предусмотрено предоставление бюджетных ассигнований Федерального бюджета бюджетам субъектов РФ и федеральным специализированным медицинским учреждениям в размере 3,629 миллиарда рублей. Через программу модернизации здравоохранения осуществлялась замена изношенного и неработоспособного медоборудования поставленного в рамках НП «Здоровье». Однако процесс модернизации оказался длительно растянутым по времени. Выделенные средства нередко тратились на приобретение не соответствующего утверждённому перечню медоборудования и нередко полностью не осваивались.

По данным контрольной счётной палаты (КСП) Волгоградской области ${ }^{164}$ при проверке эффективности региональной программы модернизации здравоохранения за 2011-2012гг на 1 декабря 2012г программа оказалась реализованной на 71\%. Первоначально запланированные на 2011 год ассигнования были исполнены лишь на 39\%, большинства целевых показателей достичь не удалось. Среди выявленных нарушений: приобретение оборудования на 287 млн. руб., не соответствующего утвержденному перечню, а также несоблюдение условий контрактов на поставку медицинского оборудования. В частности, из 42 заключенных в 2011году контрактов с нарушением сроков было исполнено 20. Вообще не было исполнено 5. Из 141 контракта, заключенного за 9 месяцев 2012 года, с нарушением сроков были исполнены 24, не исполнены 20 контрактов.

В 2008 году в рамках приоритетного национального проекта «Здоровье» предусматривалось проведение мероприятий по совершенствованию оказания медпомощи

${ }^{164} \mathrm{~B}$ модернизации здравоохранения нашли нарушения. [Электронный ресурс].-Режим доступа: http://news.mail.ru/inregions/ south/34/economics/11607246/?frommail=1/15.01.13. 
больным с сосудистыми заболеваниями, оснащение государственных, в том числе федеральных учреждений здравоохранения и учреждений здравоохранения муниципальных образований современным оборудованием, необходимым для проведения диагностических и лечебных вмешательств экстренного и планового порядка при патологии сосудов сердца и головного мозга.

В целях достижения мирового уровня развития высоких медицинских технологий в рамках ПНП Здоровье планировалось оснащение специализированных федеральных учреждений современным дорогостоящим оборудованием- роботизированными хирургическими комплексами, многофункциональными радиохирургическими и радиотерапевтическими комплексами, компьютерными и магнито-резонансными томографами, ангиографическими системами, УЗИ аппаратами экспертного класса и др.). При этом удовлетворение потребности в высокотехнологичном ангиографическом оборудовании планировалось лишь на 10-20\%.

Спустя 8 лет в 2016 году данные об обеспеченности населения ангиохирургической помощью остаются неудовлетворительными. Согласно опубликованным данным 165 собранными и обработанным и специалистами «Лиги защитников пациентов», ФБГУ «Института хирургии им. А.В. Вишневского», Института стволовых клеток человека распространенность ишемии нижних конечностей в РФ на 2014 год из всех федеральных округов РФ с суммарной численностью населения около 71 млн. человек составляет от 1,5 до 5\%. До 3 млн. больных нуждаются в помощи сердечно-сосудистых специалистов. Среди населения старше

${ }^{165}$ Три миллиона россиян нуждаются в помощи сердечно-сосудистых хирургов. Электронныйдокумент, доступ: http://www.univadis. ru/medical-news/183/Tri-milliona-rossiyan-nuzhdayutsya-v-pomoschiserdechno-sosudistyh-hirurgov?utm_source=newsletter+email\&utm medium=email\&utm _ campaign=medical+updates+-+daily\&utm content=1073686\&utm_term=automated_daily./Remedium 29.09.2016. 
40 лет в РФ распространенность симптомной ишемии конечностей $0,51 \%$, с перемежающейся хромотой $-0,36 \%$, а с критической ишемией конечностей $-0,13 \%$. Число ампутаций среди больных с диагнозами атеросклероз артерий конечности или облитерирующий тромбангит $-6,9 \%$. Исследователями был сделан вывод о недостаточно своевременной выявляемости и низкой эффективностью консервативного лечения пациентов с ишемией конечностей, что приводит к развитию запущенных форм заболевания и высоким ампутационным потерям. Результаты лечения заболеваний периферических артерий и, в частности, критической ишемии, остаются неудовлетворительными и сопровождаются высокими цифрами выполненных ампутаций и летальности. В связи с повышенной летальностью среди больных с ИБС сочетанной с заболеваниями периферических артерий Российским кардиологическим обществом в конце лета 2019 года был объявлен конкурс научно-образовательных грантов, в котором автор принял участие с проектом «Оптимизация маршрутизации и раннего выявления периферического атеросклероза сосудов нижних конечностей» (справка об участии в приложении).

Ведущие сосудистые специалисты России считают необходимым создание в РФ регистра больных с заболеваниями периферических артерий и ишемией нижних конечностей, подобно существующим в США и Европе. Это позволит точнее формировать бюджет здравоохранения для лечения подобных пациентов.

Как показали результаты выше приведенного исследования 80-90\% потребностей в диагностике лечении заболеваний периферических артерий не были удовлетворены, в том числе за счёт частных учреждениях здравоохранения. По данным опросов 2006г врачебного персонала крупного промышленного центра Западной Сибири ${ }^{166}$

${ }^{166}$ Сборник Общественной палаты Российской Федерации. -2006.-январь-июль. 
рейтинг частных лечебных учреждений в диагностическом процессе, не превышал 2,6\%. Решение вопросов повышения эффективности функционирования системы здравоохранения предусматривало по плану национального проекта поэтапный переход на преимущественно одноканальное финансирование через систему обязательного медицинского страхования. На примере России и некоторых зарубежных стран обнаружилась недостаточная эффективность функционирования одноканального финансирования медицинского страхования при планировании доступности высокотехнологичной медицинской помощи различным слоям населения.

Ряд исследователей выявили значительные различия в доступности и результативности медицинской помощи между разными социально-экономическими слоями общества в экономически развитых странах ${ }^{167}$.пределенная часть пациентов из социально уязвимых слоев не получала адекватной хирургической помощи при сердечно-сосудистых заболеваниях, частота же «избыточного» применения хирургических и эндоваскулярных методов лечения в целом составляла, по данным разных авторов, от 4 до 58\% ${ }^{168}$. В тоже время программа Medicare США и некоторые другие известные страховые программы не возмещали затрат профилактического скринингового обследования, стоимости медикаментов и кардиологической реабилитации ${ }^{169}$.

Наряду с решением технических вопросов национальным проектом «Здоровье» предусматривалось подготовка кадров. Несмотря на недостаточную оснащенность диагностических отделений современным оборудованием и недостаточность диапазона выполняемых исследований

${ }^{167}$ Krumholz Harlan M//J.A.M.A.-2007/-Vol.297.-P.1063-1072.

${ }^{168}$ Доказательная медицина и сердечно-сосудистые заболевания /Под ред. Л.А.Бокерияидр.-М.,2006.

${ }^{169}$ Thomas R.J.,Miller N.H.,Lamendolla C. et al//J.Cardiopulm/ Rehabil/-1996.-Vol.16.-P.402-412. 
во многих современных публикациях отмечен неизмеримый рост роли врача диагностического отделения, как консультанта и участника лечебного процесса ${ }^{170 .}$ Не последнюю роль при этом играют квалификация персонала, в частности, способность расширить диапазон выполняемых исследований на доступном оборудовании, что не сопровождается существенным удорожанием практически оказываемой медицинской помощи и сохраняет преимущество ее доступности.

С одновременным введением высокотехнологичной медицинской помощи Минздрав России приступил к реализации механизма её финансирования, основанного на установлении государственного заказа. Установление бюджетному здравоохранению государственного задания на услуги являлось формой финансирования, ориентированной на результат. Как правило, спланированный результат, не решал растущих потребностей. При этом обнаруживалось несоответствие государственного заказа реальному количеству нуждающихся в высокотехнологичной медицинской помощи.

Ко всему прочему оказались актуальными вопросы разработки количественно и качественно измеряемых и научно-обоснованных индикаторов и показателей, по которым можно достоверно судить о степени достижения целей поставленных Правительством России, в рамках приоритетного национального проекта в сфере здравоохранения. Данные вопросы остались до конца не решенными ${ }^{171}$.

Кроме индикаторов и показателей эффективности реализации ПНП Здоровье необходимо было решать

${ }^{170}$ Федорова Г.В,Ковалевская Л.К., Титова Е.В.// Бюл.гос.учреждения НИИ соц.гиг.,экономики и управления здравоохр. Им. Н.А.Семашко.-2003-№13.-С.110-113.

${ }^{171}$ Перхов В.И. Обеспечение населения Российской Федерации высокотехнологичными видами медицинской помощи: история, действительность, перспективы. Ж.Менеджер здравоохранения.2007.- №9.- С.37-43. 
проблему более активного участия российских производителей медицинской техники, изделий медицинского назначения и лекарственных средств в обеспечении ими учреждений, оказывающих дорогостоящую медицинскую помощь, путем улучшения качества, конкурентоспособности уровня сервиса оказываемых услуг и выпускаемой продукции ${ }^{172}$. В связи с этим Волгоградский государственный медицинский университет с 2013 года начал подготовку специалистов по ремонту медицинского оборудования.

В тоже остались не решенными правительством России и соответствующими регламентирующими приказами вопросы активного участия российских производителей медицинской техники в модернизации и инновационном использовании доступного существующего оборудования, что практически не сопровождается существенным удорожанием оказываемой медицинской помощи и сохраняет преимущество ее доступности.

Таким образом, в качестве основных проблем применения инновационных медицинских технологий в здравоохранении России следует выделить следующие:

1) недостаточный характер финансирования дорогостоящей высокотехнологичной медицинской помощи по программе ПНП «Здоровье»;

2) Необходимость замены устаревшего, часто не функционирующего медицинского оборудования поставленного ПНП Здоровье; недостаточно эффективное освоение финансовых средств с нарушением сроков поставок и нецелевым приобретением медоборудования по программе модернизации здравоохранения в российских регионах;

3) Отсутствие новой модели кадровой работы, обеспечивающей подготовку врачей к использованию нового

${ }^{172}$ Перхов В.И. Обеспечение населения Российской Федерации высокотехнологичными видами медицинской помощи: история, действительность, перспективы. Ж.Менеджер здравоохранения.2007.- №9.- С.37-43. 
медицинского оборудования и инновационных медицинских технологий. Непрерывное дистанционное интернет образование в рамках модели непрерывного медицинского образования, проводимое в России с 2014 года не снизило актуальность обсуждаемой проблемы;

4)Недостаточное участие российских производителей медицинской техники в ремонте, модернизации и инновационном использовании доступного существующего медицинского оборудования;

5) Не разработанность научно-обоснованных измеряемых индикаторов и показателей в достижения целей, установленных правительством России в рамках модернизации сферы здравоохранения;

6)Недостаточная оптимизация норм применения налогового стимулирования объектов интеллектуального труда на экономическом рынке; недостаточность налоговых преференций, благоприятного законодательно-правового поля для венчурных инвестиций в патентные медицинские инновации;

7) Сложность процедуры подготовки документов и достаточно большая продолжительность регламента выдачи разрешения на применение новых медицинских технологий и изделий медицинского назначения Росздравом как для физических, так и для юридических обладателей медицинских патентов.

8)Отсутствие законодательно утверждённых требований, предъявляемых к медицинским изделиям для государственной регистрации, включая изделия медицинского назначения, используемых во вновь регистрируемой медицинской технологии; законодательная противоречивость определенного статуса испытательной организации, с которой изготовителю необходимо согласовать документацию на медицинское изделие, используемое самостоятельно и в составе вновь регистрируемой медицинской технологии. 


\section{РАЗДЕЛ ІІ. МАТЕРИАЛЫ И МЕТОДЫ СОБСТВЕННЫХ ИССЛЕДОВАНИЙ}

\section{Глава 2.1.Организация исследования}

Проведено анкетное исследование 452 работающих врачей г.Волгограда (сплошные гнездовые выборки) в 2009-10 году.

\section{Глава 2.2. Методы социологического}

\section{исследования и обработки материала}

Анкетирование врачей проведено методом гнездовых выборок с помощью специально разработанной анкеты. Математическую обработку результатов исследования проводили методами параметрической (критерий Стьюдента) и непараметрической статистики с использованием многофункционального критерия Фишера (угловое преобразование Фишера). Для расчета доверительных интервалов и доверительных вероятностей использовалась функция ошибок в виде $\mathrm{t}$ - распределения Стьюдента(метод t- критерия Стьюдента).Статистически достоверным считали изменения по критерию Стьюдента при р <0,05;По критерию Фишера $\psi^{*}=1,64$ при $\mathrm{p}<0,05 ; \psi^{*}=2,31$ при $\mathrm{p}<0,01$; $\psi^{*}=2,81$ при р $<0,001$. Результаты опроса обрабатывались на компьютере программой IBM SPSS 22. 


\section{Раздел III. ГЛава 3. РЕЗУЛЬТАТЫ СОБСТВЕННОГО ИССЛЕДОВАНИЯ}

\section{ГЛава3.1. СОЦИОЛОГИЧЕСКИЕ АСПЕКТЫ ИНТЕЛЛЕКТУАЛЬНОЙ СОБСТВЕННОСТИ И ИЗОБРЕТАТЕЛЬСТВА}

\section{Социальные истоки становления эвристики изобретательства}

Изобретательство - возникло из потребностей практики как один из видов творческой, древнейшей и консервативной по методике применения деятельности. Как в древности, так и в наше время, абсолютное большинство изобретателей применяют метод проб и ошибок, заключающийся в последовательном переборе различных идей. Правил поиска нет, и решение находится случайно. Нет также и правил первоначальной оценки пригодности идей. Таким образом, история развития эвристики изобретательства методом проб и ошибок имеет глубокие исторические корни.

Ассоциативные методы, позволяющие систематизировать поиск новых решений, известны давно. На ассоциации основан применяемый сознательно (известный еще Аристотелю) универсальный прием творческого поиска - по аналогии, под которой понимается сходство каких-либо отдельных признаков различных объектов или решений. Аналогия позволяет на основе представления о свойствах одного объекта сделать предположения, относящиеся к другому. Данный подход до сих пор используется как способ проведения дифференциального диагноза в медицине. Однако до сих пор науки о творчестве на основе аналогии нет, хотя данный способ в практике поиска решений применяется достаточно часто. 
Знания о творчестве рассматривались и рассматриваются многими науками, в том числе философией, психологией, науко- и искусствоведением, медицинской кибернетикой и информатикой. В каждой их них свое видение и методы, но рекомендаций по активации творчества мало. Философы и ученые различных областей знаний уже в древности пытались определить закономерности творческого мышления.

Разработку учения об эвристических методах начал еще древнегреческий философ Сократ. Он ставил цель преподавать не готовую систему знаний, а метод, с помощью которого можно создавать систему. Наводящими вопросами он стимулировал пробуждение скрытых творческих способностей людей и создание ими продуктивных идей. Метод назывался майотикой Сократа, что дословно означало «акушерское искусство».

Архимеду принадлежит подробное учение о методах рассмотрения и решения задач. С помощью упрощенных представлений (моделей) он выдвигал и обосновывал гипотезы. В труде «Стомахион» он описал способы создания отдельных технических объектов из уже известных элементов. Термин «эвристика» (от легендарного возгласа Архимеда «Эврика!» - «Нашел!») ввел древнегреческий математик Папп Александрийский в III веке н.э. Под этим названием он объединил методы решений математических задач, отличные от чисто логических. Упадок античных наук привел к забвению на многие века и некоторых начал эвристики.

Только в XVI-XVII вв. в трудах Г. Галилея и Ф. Бэкона возродились эвристические подходы в науке. Первым попытался описать логику создания изобретения инженерного сооружения Г. В. Лейбниц (XVII-XVIII вв.). Он призывал пользоваться разумом так, чтобы «оценивать не только явное, но также и изобретать,т.е. открывать скрытое».В медицине, где многие патологические процессы протекают, 
скрыто от глаз врачевателя, социальная необходимость изобретать возможность выявления скрыто протекающих патологических процессов с целью лечебного воздействия на них всегда стояла особенно остро.

В дальнейшем изобретательство совершенствовалось в трудах X. Вольфа (XVII-XVIII вв.), чешского математика и философа Б. Больцано (XVIII-XIX вв.) и в работах российского инженера-патентоведа П. К. Энгельмейера (начало XX в.).

До конца XIX в. темпы технического прогресса были таковы, что метод проб и ошибок в изобретательстве обеспечивал спрос на новые разработки. Примером высочайшего уровня использования этого метода была деятельность великого американского изобретателя Томаса Эдисона, обладавшего колоссальной работоспособностью. Он создал творческий коллектив, обеспечивающий перебор огромного количества вариантов, поделив поле поиска на участки, компенсируя этим недостатки метода проб и ошибок.

Психологи пытались в экспериментах по-своему воспроизвести процесс решения творческих задач, но обычно для этого использовали головоломки и загадки, а не изобретательские задачи. Психологи-бихевиаристы основной упор делали на поведение человека и констатировали чисто внешние признаки процесса решения. Так, например, гештальт-психология объясняла творчество следующим образом: человек создает мысленный образ (Gestalt) объекта, перестраивает его, меняет связи между элементами до тех пор, пока неожиданно не возникает новое решение, удовлетворяющее поставленной цели. Но ответа на то, как рождается новое решение, найдено не было.

В настоящее время - быстрого развития медицинских технологий и медтехники, а также ужесточения требований к их безопасности и экологичности метод проб и ошибок, по сути, обеспечивавший совершенствование 
технологий и техники в течение долгого времени, перестал удовлетворять требованиям практики. Действительно, опыт свидетельствует, что решение даже простых задач занимает порой много времени. В медицине, как ни в одной другой области знания, чем раньше может быть достигнут положительный результат, тем больше может быть социальное значение найденного решения. Метод проб и ошибок не только неэффективен при решении важных медико-социальных задач, но и затрудняет их постановку, не позволяет одновременно увидеть значимые проблемы, отодвигая их решения порой на целые десятилетия. Даже при решении одинаковых задач методом проб и ошибок разные люди по-разному ищут решения и по-разному их решают.Общим для каждого известного метода является очень малая вероятность быстрого нахождения одинаково оптимального и эффективного решения. 


\section{Глава 3.2. СПОСОБЫ ФОРМИРОВАНИЯ ИНТЕЛЛЕКТУАЛЬНОЙ СОБСТВЕННОСТИ}

«Отсутствие общественной ответственности, нежелание задавать вопросы-будь то в искусстве или в профсоюзном движении-зиждется на убеждении,что в данном обществе нет серьёзных проблем, требующих внимания и действий». ${ }^{173}$

Для обсуждения серьёзных общественных проблем, требующих внимания и действий, необходимо публично задавать вопросы и искать на них ответы. Проблемы формирования интеллектуальной собственности и изобретательской деятельности в России не являются исключением. В начале рассмотрим перечень способов формирования интеллектуальной собственности и изобретательской деятельности, а затем препятствия институализации их результатов.

Методику формирования объектов ИС можно разделить на две группы. К первой относятся специальные психологические методы, позволяющие избежать инерционности в формировании направленности поиска. При этом создаются вероятностные ситуации, активизирующие ассоциативные способности человека и увеличивающие не только число проб, но и число направлений поиска. Наиболее известны из них: мозговой штурм и синектика. Ко второй группе относятся методы, позволяющие систематизировать перебор вариантов, увеличить их число, исключить повторы и постоянный возврат к одним и тем же идеям. Сюда относятся морфологический анализ и метод контрольных вопросов. Особое место занимает ТРИЗ. В основе последнего лежит постулат: технические системы развиваются по объективным законам - эти законы можно выявить и сознательно использовать для решения изобретательских задач. Но необходимо также фундаментально

${ }^{173}$ В.В. Познер. Прощание с иллюзиями. Москва: «Изд-во АCT».2016г. 
овладеть естественными законами, знание которых, с одной стороны, позволит существенно повысить эффективность разработок, а с другой,- выдерживать принцип «не навреди» Человеку, Природе и рукотворной окружающей среде.

Мозговой штурм, созданный в конце 30-х гг. А. Осборном (США) имеет ряд модификаций: групповое решение задач, концентрация идей, массовая мозговая атака и др. Основная идея - отделение генерирования новых идей от их оценки путем запрета критики, что позволяет высказывать смелые идеи, не боясь насмешек, отрицательного отношения руководства и коллег. Поощряется любая идея, в том числе и шуточная, и явно нелепая. Обычно в группу включаются 6-8 человек, склонных генерировать идеи. Руководители не включаются. Создается непринужденная обстановка. Идеи стенографируются или записываются на магнитофон, а затем передаются группе экспертов для оценки и отбора. За час группа из 8 человек может выдвинуть 50-60 идей, из которых 1-2 могут оказаться эффективными.

Мозговой штурм, как показал опыт его применения, эффективен, когда ведущий имеет большой опыт решения задач, владеет техникой общения, обладает личным обаянием, остроумием и многими другими качествами. Но и в этом случае успешно решаются относительно несложные задачи. Наибольшие успехи данным способом достигались при решении управленческих задач.

Метод синектики разработан в 50-е гг. У. Гордоном (США). В основе лежит мозговой штурм, проводимый профессионалами со значительным опытом такой работы. Синектика допускает конструктивную критику. Обучение синекторов возможно только на практике. Большинство синекторов прекращали свою деятельность через несколько лет, возможно, из-за разрушающего влияния метода на нервную систему. 
Применяется обратный штурм, который поощряет критику, потому что только так можно выявить недостатки кажущейся «благополучной» идеи, конструкции или другой разработки.

Усиление «растормаживания» людей и избегание привычных, а потому часто бесплодных ассоциаций возможно, если взглянуть на объект под необычным углом. Это достигается в методе фокальных объектов, предложенном в 1926 г. Э. Кунце (Германия) и Ч. Вайтингом (США). Совершенствуемую техническую систему держат как бы в фокусе внимания, перенося на нее свойства других, не имеющих к ней никакого отношения объектов. Получающиеся необычные сочетания стараются развивать путем свободных ассоциаций. Наибольший эффект достигался при поиске новых возможностей выпуска товаров народного потребления для решения задач рекламы. Может быть применен и для тренировки творческого воображения при обучении изобретательству.

Морфологический анализ создан швейцарским астрофизиком Ф. Цвикки, предсказавшим с помощью этого метода существование нейтронных звезд. Сущность морфологического анализа заключается в стремлении систематически охватить все (известные или хотя бы главнейшие) варианты структуры совершенствуемого объекта. В совершенствуемом объекте анализируются характеристики и основные узлы или элементы, для которых составляется перечень возможных исполнений; выбираются наиболее интересные их сочетания. Удобнее всего выполнять анализ с помощью многомерной таблицы, называемой морфологическим ящиком, в котором выбранные характеристики или элементы играют роль осей. Основным недостатком метода является чрезвычайно большое количество возможных комбинаций. Так, например, если на 10 основных осях рассмотреть по 10 вариантов, то число возможных комбинаций составляет 
$10^{10}$. Перебор различных вариантов может быть получен лишь с помощью ЭВМ. Но среди этой массы, в основном слабых, а иногда вообще бессмысленных сочетаний, даже с помощью персонального компьютера очень сложно найти единственное «сильное» решение. Данный метод эффективен для несложных систем с малым числом комбинаций или когда нужно найти эффективные способы реализации уже найденного решения. Повысить эффективность поиска можно, если заранее сформулировать наводящие вопросы (метод контрольных вопросов).

Все упомянутые методы, разработанные изобретателями-практиками, повышали эффективность практической изобретательской деятельности, но не отвечали на вопрос, как появляются новые идеи. Не добились успеха в этом вопросе и ученые-психологи, исследующие творчество.

Необходим был другой подход. В его основу было положено изучение технических систем, их развития, а также историко-технические материалы, прежде всего патентного фонда. Изучение этих материалов показало, что жизнеспособны изобретения, изменяющие исходную систему в соответствии с законами развития технических систем. Знание этих закономерностей позволяло резко сузить зону поиска, заменив угадывание научным подходом. Практически единственной, основанной на этом подходе методологией поиска новых решений, стала ТРИЗ (технология решения изобретательских задач, обеспечивающая положительные результаты, доступная для массового применения и не влияющая вредно на психику). Основными механизмами ТРИЗ являются алгоритм решения изобретательских задач (АРИЗ) и система стандартов на решение изобретательских задач. В ТРИЗ имеются свои методы и приемы, основным из которых считается вепольный анализ (Вещество -поле). Веполь - это минимальная модель технической системы, отражающая самые 
основные элементы, например, изделие, инструмент и энергию (поле), необходимую для воздействия инструмента на объект(изделие, орган или организм человека). Модель сложной системы сводится к сумме веполей. Однако для эффективного использования ТРИЗ необходимы универсальные целостные знания на фундаментальном уровне, который не предусмотрен традиционным высшим образованием, что является основным препятствием для массового внедрения ТРИЗ. Широта знаний на уровне понимания сущности позволяет быстро и комплексно оценить взаимосвязи и найти оптимальное решение, обеспечивающее существенное повышение эффекта по сравнению с решениями, найденными методами проб и ошибок. Интересно, что данное эффективное решение может широко использоваться в различных областях не только технических, но и гуманитарных дисциплин, включая медицину.

ТРИЗ может рассматриваться как углубление функционально-физического анализа систем. Максимальная эффективность может быть достигнута там, где использование ТРИЗ носит не эпизодический характер, а охватывает весь цикл производства - от проектирования нового изделия до его модернизации. Такой подход реализуется в рамках системы функционально-стоимостного анализа (ФСА).Суть ФСА заключается в следующем: применение системного подхода для выявления, по возможности, всех излишних затрат (трудо-, энерго-, материалоемкость и других) в существующих или проектируемых технологиях или устройствах; применение методов инженерного творчества, направленных на повышение функциональных характеристик и снижение затрат всей системы; четкая эффективная организация работ.

Рассмотренный перечень способов формирования интеллектуальной собственности и изобретательской деятельности подчеркивает многоплановость 
инновационного творчества, недостатки способов и возможности его образовательного развития в рамках подготовки специалистов не только технических, но и гуманитарных профессий. Выбор наиболее эффективных форм обучения инновациям, является новым экономическим институтом в сфере образования, в частности образовательным франчайзингом, который в России ещё только формируется.

Согласно нового обсуждаемого закона об образовании (первое чтение прошло в ГД 6 октября 2012года) объектом коммерческой концессии (франчайзинга) в сфере образования является комплекс принадлежащих юридическим или физическим лицам исключительных прав на образовательные программы, методики и технологии обучения, воспитания и контроля качества образования, включая право на коммерческое обозначение(наименование), товарный знак, знак обслуживания. По договору коммерческой концессии в сфере образования правообладатель обязуется предоставить организации-пользователю, осуществляющей образовательную деятельность, за вознаграждение на срок или без указания срока право использовать комплекс принадлежащих правообладателю исключительных прав, деловой репутации и опыта обучения.

С исключительными правами, деловой репутацией и, главное, с результатами реализации научно-образовательного франчайзинга в России сложилась совершенно уникальная ситуация.Уникальность ситуации в отчуждении имущественного права на исследовательский результат, являющийся объектом интеллектуальной собственности, в стратегических областях науки. Нонсенс. За доступ к публикациям своих разработок в зарубежных научных изданиях ученые российской академии наук платят представителю американского бизнеса. Государство вкладывало и продолжает вкладывать деньги в разработки, без права 
первой публикации результата. Логичен вопрос, возможно ли такое и каким образом? Ответ-возможно. Его механизм «как и почему?» рассмотрим подробно.

По иронии судьбы в период гласности и перестройки в СССР с 1989 года научные журналы, выпускаемые РАН, оказались скупленными издательским холдингом Pleiades Publishing, принадлежащим американцу советского происхождения Александру Шусторовичу.

Реформа РАН идет не один год. Однако сфера, которую реформа не затронула, - это рынок научных публикаций. Лидер движения «За честную страну!» Вера Мысина утверждает:«Это дико, когда вся публикационная деятельность РАН - святая святых российской науки - принадлежит американцу. Парадокс в том, что об этом мало кто знает. Когда она впервые услышала эту информацию, то не поверила. ....Рядовые научные сотрудники РАН были не в курсе. А академики и члены-корреспонденты это не комментируют. Это большие деньги, бизнес никто не позволит разрушить» ${ }^{174}$.

Куда более удивительно то, что на протяжении двух десятилетий научные издания Российской Академии наук контролируются частным лицом при молчаливом согласии академических кругов. По сути, американский предприниматель занял очень хороший сегмент рынка, который долго не был интересен другим крупным игрокам в издательском бизнесе. Публикуют он только самое интересное, что можно продать на Западе. Ученые передают все авторские права на публикацию компании Pleiades Publishing, дальше Шусторович уже продает доступ к публикациям через интернет. Его базу данных, а точнее свои публикации в этой базе, вынуждены покупать крупнейшие российские ВУЗы и библиотеки. В результате

${ }^{174}$ Кому принадлежит российская наука. Елена Сердечнова.Общество, Закон. 18 июня 2015, 06:43. URL источник Русская планета http://rusplt.ru/society/komu-prinadlejit-rossiyskaya-nauka-17518.html 
сложившейся ситуации логично задаться вопросом: справедливо ли контролирование научного сообщества России представителем иностранного бизнеса? Чему и кому служит новый экономический институт в сфере науки и образования России? Ответы не в пользу России. Пока российский учёный не опубликовался за рубежом, он никем не признан. Без статьи в иностранном журнале ученый не получит и российских грантов. А это означает, что в руках у «Шусторовичей» есть рычаг воздействия на научно-образовательные реформы в России, с помощью которого можно, как минимум, тормозить, как максимум блокировать любого российского исследователя, лишив его доступа к грантовым источникам финансирования, в том числе к наиболее известным в мировой науке. Вопрос: как и для кого идёт формирование объектов интеллектуальной собственности и инноваций в области Российской науки и образования? Не до конца ясен. 


\section{ГЛава 3.3. СОЦИАЛЬНО-КУЛЬТУРЫЕ АСПЕКТЫ ИНТЕЛЛЕКТУАЛЬНОЙ СОБСТВЕННОСТИ И ИЗОБРЕТАТЕЛЬСТВА}

По мнению экспертов Евросоюза “...идея, даже самая плодотворная, если не используется большей частью гибнет. В лучшем случае хорошая мысль тормозится и задерживается на десятки и сотни лет. Человечество же остается в страшном убытке...”. В начале XXI века в общественном пути развития резко возросла ценность интеллектуальной собственности, увеличились масштабы ее использования и скорость освоения. Интеллект - «познавательная способность человека» - становится все более важным фактором общественного производства и творения общественных ценностей («интеллектуальный капитал», «душевное имущество»),которые все больше приобретают значение одной из основных целей экономического развития. Однако катастрофическое отставание фундаментальных социологических исследований в области «интеллектуального капитала» в РФ привело к нечеткому представлению и недостаточному пониманию значения концепции социального развития институтов «интеллектуальной собственности», инновационного мышления и инновационной культуры, необходимых для эффективного освоения «интеллектуального капитала» как в общественном производстве, так и в технологиях восстановлении здоровья населения. В результате отсутствует общепризнанная интеллектуально-концептуальная модель эффективной защиты здоровья населения. Имеющаяся научная литература, как правило, посвящена рассмотрению отдельных социально-правовых институтов-авторского, патентного, административного, уголовного права и других. При этом ясность общественных целей в решении проблем социально-правовой сферы регулирования медицинского оборота «интеллектуальной собственности» отсутствует, 
что препятствует формированию «успешной институализации» медицинских разновидностей интеллектуальной собственности что, в свою очередь, недостаточно эффективно влияет на внедрение интеллектуальной собственности в сферу экономики медицины и развитие законодательства, призванного служить надежной «юридической оболочкой» для успешного развития соответствующих инновационных технологий и социально-экономических отношений. Существует множество определений понятия «Инноваций». Обобщенным и, в то же время, наиболее содержательным является следующее понимание этого термина. Инновация - это внедрение и использование новых товаров, услуг в различных областях с целью получения экономического (в первую очередь), социального, научно-технического и других видов эффекта.

В социально-значимом аспекте понимание инновации (позднелат. Innovatio,англ. Innovation - нововведение) - определялось как явления культуры, которых не было на предшествующих стадиях её развития,но которые появились на данной стадии и получили в ней признание («социализировались») и закрепились (зафиксировались) в знаковой форме и в деятельности посредством изменения способов, механизмов, результатов, содержаний самой этой деятельности. В последнем случае чаще используют понятие «нововведение», выражая его сущность в терминах инновационной деятельности и инновационных процессов (если учитывается процесс сопряженных изменений в среде) и раскрывая его содержание как комплексный процесс создания, распространения и использования нового практического средства (новшества) для удовлетворения человеческих потребностей, меняющихся в ходе развития социокультурных систем и субъектов. Однако это суждение отражает предметизацию понятия инновации под задачи конкретных сфер человеческой деятельности - менеджмент и теорию управления различными 
социологическими процессами- социологией экономики, различного права, науки и других общественных процессов. Второе понимание инновации может быть рассмотрено более широко в рамках культуры как технологизации первого понимания инновации. В этом общем случае исходным (базовым) выступает представление о культуре как сложноорганизованной целостности, формируемой двумя типами разнонаправленных процессов. Первым типом процесса креативности (изменений,обновлений, творчества и т.д.) культуры и вторым типом процесса структуирования (упорядочивания, нормативности, традиционализации и так далее).

Суть упорядочивающих интенций культуры-это стеротипизация возможных внутри нее форм активности (деятельности, общения,мышления) и стандартизация и хабитуализация (опривычивание) имеющихся в ней наличных содержаний, что закрепляется структурно-институционально. Ядерная структура здесь-культурная традиция как универсальный информационно-регуляционный механизм, осуществляющий селекцию, оформление а тем самым и модификацию, закрепление, т.е. интеграцию в культуре, попадающих в поле её деятельности новшеств, как создаваемых внутри данной культуры (инновации культуры, связанные с авторским или анонимным творчеством, «креационные» инновации),так и заимствуемых из других культур. Конечная цель этих процессов и их деятельности-превращение инновации в норму, традицию. Креативные же процессы и деятельности в культуре направлены на дестереотипизацию деятельности, общения, мышления, дестандартизацию уже имеющихся наличных содержаний, проблематизацию «очевидностей», деструктуризацию и деинституционализацию (в известных пределах) сложившихся ценностей. Образующей «структурой» в таком случае выступает процессуальность творчества, под которой понимается « создание нового качественно новым 
образом, по существенно новым правилам»,т.е. продуцирование креационных инноваций, а также введение в качестве таковых в культуру инновации-«заимствований».

Проблема культурных заимствований специально разрабатывалась в парадигме диффузионизма в антропологии; одна из последних версий роли инновационных заимствований предложена Г.Грачевым в концепции «ускоренного развития литератур».Конечная цель этих процессов и деятельностей-изменение через инновации существующих норм и традиций, или обеспечение возможности порождения иных традиций и норм регулирования. Кроме того, под воздействием инноваций и перестройки наличных нормативных систем и традиций в культурных системах могут порождаться резонирующие эффекты культурных мутаций (влияние прежде всего «креативных» инноваций)и культурных трансформаций (влияние прежде всего инновационных «заимствований»). Вектора креативности и структуирования (при всей их разнонаправленности) не только предполагают одновременное существование соответствующих процессов и деятельностей, но их реальную совмещенность в функционировании и развитии культурных феноменов, включающих инновационное творчество.

Любая инновация становится достоянием культуры лишь встраиваясь в наличные системы норм и традиций, т.е. стереотипизируясь и стандартизуясь. Практически всякий стереотип и стандарт генетически произведен от имевшей место в культуре инновации. Однако в конкретных исторических и социальных аспектах соотношение этих векторов позволяет различать культуры «инновационного» и «традиционного» типов (соответственно «культурных грамматик» и «культуры текстов», в терминологии Ю.Лотмана.В обоих случаях речь идет о различном соотношении традиций и инноваций в культуре, а также о специфике способов введения инноваций в традицию, 
то есть о разных технологиях институализации нововведений. В этом отношении различимы архаические, традиционные и современные социальные структуры (общественная палата при Гд, Российская медицинская ассоциация и другие) и разные типы культурного кодирования: лично-именной (модель- охотничье общество,); профессионально-именной (модель-кастовая система типа врачебных саморегулируемых сообществ) и универсально-понятийный (основы заложены в античности, развит в христианстве, дооформлен в новое время, модель-индустриальное общество).

Социокультурный код задает различные механизмы дифференцирования(фрагментации) и интегрирования наличных массивов знания и культурного опыта, способы их доведения до потребителей, а главное -различные механизмы трансмутации-появления новых элементов или модификации наличных в социокоде, в каком-либо его фрагменте и в соответствующем канале трансляции знания и опыта, что меняет в том числе и механизмы преемственности наследуемых обстоятельств и закрепляющие их «интерьеры» деятельности. Изменения в «интерьерах» деятельности по сути вторичны и могут быть рассмотрены как «технологизация» «первичных», смысловых культурных инноваций.

«В подавляющем большинстве случаев у индивида нет другого пути воздействовать на общесоциальную сумму обстоятельств, кроме как модернизировать унаследованный им фрагмент знания. Наращивая свой фрагмент общественных знаний, субъект создает прецеденты выхода его за собственные границы (проблема «вместимости» фрагмента) и ставит задачу: с одной стороны, на необходимость его сжатия, с другой стороны, на одновременное расширение смыслового содержания инновационного фрагмента знаний. Например, сжатием патента на изобретение до его описания через формулу изобретения, с одной стороны, с одновременным расширением смыслового 
содержания инновации через описание к патенту на изобретение. Параллельно решается задача знакового оформления и внедрения инновации (её признания) в интеграционную целостность общественных фрагментов знания через публикацию сведений, например, о патенте через информационные ресурсы. Такие ресурсы,например, как библиотека патентов на изобретения web сайта роспатента (www.freepatent.ru). «Вместимость» инновационного фрагмента, тип редукции, механизмы знакового оформления инноваций через различные социокоды делят культуру инноваций на традиционные- «культуры текста и имени», художественных произведений и универсально-понятийно закодированные «культуры грамматик», например, классификация изобретений по МКИ-международному классификационному индексу.

Жизненный цикл инновации в универсально-понятийно-закодированном типе культур хорошо описывается по аналогии с массивом дисциплинарно-научного знания, меняющегося под воздействием полученного нового результата, его публикации и обсуждения. При этом закодированная новационная структура научной дисциплины может быть рассмотрена как универсальная, обеспечивающая внутри себя связь старых и новых инновационных знаний, заданных публикациями достигнутого, новой парадигмой решений в ближайшем будущем. Опосредование инновационного опытом имеющимся меняет сам массив инновационно-наличных результатов за счёт введение в него новых обобщенных смыслов и значений. Изменения значений (смыслов) в массиве инновации расширяется и уточняется, закрепляется, институализируется посредством публикаций (рефераты научных статей, изобретений) и коммерциализируются через лизинг и другие возможные пути в экономике.

Таким образом, инновации существуют с незапамятных времен и выражают суть процессов социальных 
изменений направленных на ревизию устоявшихся общественно-производственных отношений, нередко с их заменой. В этом одна из основных социокультурных значений инноваций-развитие общественной практики, обогащение её новыми познавательными, технологическими, эстетическими и всеми другими формами человеческого опыта.

Инновация определяется двойственной природой. С одной стороны, как непосредственный опыт, формирующийся в рамках конкретного вида деятельности (научно-исследовательской, производственной, бытовой, социальной и т.д.), с другой стороны, как новый опыт, получивший общесоциальное и общекультурное значение в качестве устойчиво воспроизводимого элемента общественной практики, явления, факта, культуры. При этом в новом опыте социально-культурное значение инновационной деятельности эксплицируется и конкретизируется через законодательное поле интеллектуальной собственности. В части IVстатьи 1259 ГК РФ определение интеллектуальной собственности дано как результата интеллектуальной деятельности, которому предоставляется правовая охрана.

Правовая охрана может быть обеспечена в рамках патентного, авторского права и некоторых смежных норм права.На объекты интеллектуальной собственности признаются интеллектуальные права, обеспечивающие правообладателю временную монополию на их использование, что является важным преимуществом в конкурентной рыночной борьбе. Сегодня в России актуальна проблема конституционно-правовой институализации нтеллектуальной собственности в государственно-законодательных и исполнительных структурах власти. Данная проблема требует тщательного исследования и оценки мер поддержки российских производителей и владельцев интеллектуальной собственности для приведения их в соответствие 
с международными стандартами и требованиями в связи с присоединением России к ВТО и к соглашениям по торговым аспектам прав интеллектуальной собственности (TRIPS). В связи с этим возникает необходимость не только постоянного социологического мониторинга процесса институализации объектов интеллектуальной собственности в сфере культуры и медицины, в частности, но и отслеживания факторов, включая законодательные, препятствующие процессу институализации новаций.

Определяющая роль в создании и совершенствовании отрасли законодательства об интеллектуальной собственности в любой стране принадлежит конституции. Часть I ст.44 конституции РФ гласит: «Каждому гарантируется свобода литературного, художественного, научного, технического, и других видов творчества, преподавания. Интеллектуальная собственность охраняется законом. В ст. 71 конституции РФ правовое регулирование интеллектуальной собственности прямо отнесено к ведению РФ. Таким образом, охрана интеллектуальной собственностиважная конституционная гарантия свободы творчества, изобретательства и институализации новаций.

Интеллектуальная собственность, по сути, структурирует социально правовую форму креативного вектора новации. Так как, во-первых, интеллектуальная собственность - это содержательный контент инновационной деятельности, креативному вектору которого предоставляется конституционно гарантированная свобода творчества и результатов творчества. Во-вторых, в России, как и в экономически развитых странах, объектам интеллектуальной собственности предоставлена правовая охрана.

Мировой опыт показывает, что свобода творчества без правовой охраны, экономически неэффективна. Кроме того, продажа инноваций и инновационных технологий возможна в форме готовых продуктов потребления и лицензий на технологии их производства, т.е. договоров о 
передаче прав на использование объектов интеллектуальной собственности.

Таким образом, результат интеллектуальной деятельности, получивший правовую охрану, представляет собой механизм перевода нововведений из теоретической сферы в сферу непосредственного экономического и общественно-исторического опыта. Примером является технический прогресс человечества, основой которого послужило использование в общественной практике изобретений и открытий математики, физики, химии, машиностроения. Такой перевод осуществлялся в форме прагматизации (коммерциализации) новых продуктов интеллектуальной собственности, которые перепродавались, переводились в нормы практической деятельности, и выводились из сферы познавательного процесса с переоформлением в инновационный процесс в новых системах технологической деятельности.

Любой инновации присущ инновационный образ мышления, а именно активный способ восприятия и оценки объектов внешнего мира, связанный с необходимостью постоянной разработки и освоения новых моделей взаимодействия с ним. В условиях действия универсального закона конкуренции, влияние которого пронизывает все сферы общественного и природного бытия, инновационный образ мышления становится необходимой предпосылкой выживания и развития индивидов и социальных ресурсов на фоне стремительно возрастающих общественных потребностей, что обусловливает «инновационность» современного мышления в качестве неотъемлемой характеристики развития демократического общества.

Инновационный образ мышления представляет собой скорее специфический подход к организации деятельности, чем набор уже готовых выводов относительно способов осуществления нововведений. Будучи своеобразным интеллектуальным инструментом, обеспечивающим 
особую технику протекания мыслительных процессов, инновационный образ мышления становится основным источником инновационной культуры, ценностно-нормативная сфера которой включает наиболее распространенные в данном обществе представления о типах нововведений и методах их реализации. Внешним проявлением инновационного образа мышления выступает тот или иной вид инновационно-группового поведения людей, в частности определенных профессий и профессиональных сообществ,которые преобразуют инновационные способы мышления в практику деятельности государственных структур, осуществляющих социокультурную сферу жизни общества.

Примером инновационно-группового поведения и мышления является медико-социальная Хартия Российской Федерации от 16 апреля 2004 года,принятая на IV (XX) Всероссийском съезде врачей. Во врачебной декларации данного документа прямо указано: «..a)государство не должно осуществлять руководство профессиональной деятельностью медицинских работников и развитием врачебного самоуправления, но обязано обеспечивать надлежащие условия для их осуществления; б)регламентация и оценка деятельности медицинских работников осуществляется профессиональными общественными медицинскими организациями, объединенными в Российскую медицинскую ассоциацию, опирающимися в этом на ученых, специалистов-экспертов и взаимодействие с федеральными и региональными органами власти и управления» ${ }^{175}$.

В консенсусе медико-социальной хартии Российской Федерации выделена её социально значимая концептуальная основа для: разработки законодательных и нормативных актов по охране здоровья, развитию здравоохранения

${ }^{175}$ Медико-социальная Хартия Российской Федерации.2004.16с. 
на государственном и региональном уровнях; для планирования и осуществления мероприятий, направленных на сохранение и улучшение здоровья населения; для разработки эффективных форм и методов профилактики и лечения заболеваний; для определения справедливой оплаты труда медицинских работников; создания надлежащих условий для успешной, качественной и эффективной деятельности их в различных ситуациях; для социальной защиты и удовлетворения профессиональных и духовных потребностей медицинских работников; для дальнейшего развития и совершенствования профессионального врачебного самоуправления.

Во многих странах с переходной экономикой кроме врачебных сообществ имеются сообщества изобретателей ${ }^{176}$, что является прямым следствием старого способа признания и поддержки изобретателей, а именно, с помощью поощрений. Такая система поддержки групповых сообществ не совсем совместима с рыночным подходом. Сообщество изобретателей неоднородно и не все изобретения годятся для внедрения в экономику и производство. Создание сообщества малых и средних предприятий, могло бы стимулировать поддержку таких изобретателей. Например, через Российскую медицинскую ассоциацию и врачебные сообщества, имеющие коммерчески осуществимые изобретения в условиях создания нового бизнеса.

В крайнем случае изобретатели могут заключать лицензионные договоры с иностранными компаниями, такими как «Milgrom \& Associates» Валерия Мильгрома. Подобная практика предусматривает преобразование изобретений в инновации за рубежом. Не все изобретения проходят успешно такой процесс трансформации, а это

${ }^{176}$ Руководство по разработке стратегии в области интеллектуальной собственности в странах с переходной экономикой. Версия 1. Подготовлено Отделом некоторых стран Европы и Азии. Всемирная организация интеллектуальной собственности.2007. С.22. 
означает, что многие изобретатели в России не получают материального вознаграждения за свои патенты. Такая ситуация хотя и является весьма обычной для всех рыночных экономик, однако для России она не оптимальна. Так как не обеспечивает достаточно эффективного уровня развития национальной экономики, изобретательских сообществ, социальной защиты и удовлетворения профессиональных и духовных потребностей медицинских работников; дальнейшего развития и совершенствования профессионального врачебного самоуправления. 


\section{ГЛава 3.4. ВКЛАД ИНТЕЛЛЕКТУАЛЬНОЙ СОБСТВЕННОСТИ В ЗДРАВООХРАНЕНИЕ (НА ПРИМЕРЕ ЗАРУБЕЖНЫХ СТРАН И РОССИИ)}

Минздравсоцразвития РФ и фонд Sk заключили 5 апреля 2011 года соглашение о сотрудничестве в лице заместителя министра здравоохранения РФ Вероники Скворцовой и исполнительного директора биологических и медицинских технологий Игоря Горянина. «Это соглашение мы расцениваем как эпохальное поскольку новый этап развития здравоохранения связан с инновационным развитием»-сообщила прессе Вероника Скворцова ${ }^{177}$.

Вклад интеллектуальной собственности в здравоохранение включает создание, распространение и практическое применение новых видов и способов человеческой деятельности (нововведений) с трансформацией в социально-культурные нормы и образцы, обеспечивающие её институционное оформление, интеграцию и закрепление в общемедицинской культуре общества.

Инновационный процесс выражает суть процессов социальных изменений, характеризуют источник и направление развития общества.Он одна из главных социокультурных предпосылок развития общественной практики, обогащения её новыми познавательными, технологическими и всеми другими формами человеческого опыта.

Эти процессы носят дискретный, обычно циклический характер, тесно связанный с жизненным циклом нововведения и направленный не на сохранение уже имеющегося, а на его трансформацию, на переход в иное качество, с неизбежным риском не оптимальности или даже нежизнеспособности предлагаемого, с ревизией

${ }^{177}$ [Электронный ресурс]. Режимдоступа: http//community.Sk.ru/ press/b/weblog/archive/2011/04/05/minzdravsocrazvitya-rf-i-fond_ skolkovo-zaklychili-soglashenie-o-sotrudnichestve.aspx 
устаревших норм и социальных ролей, а также нередко с негативными последствиями их замены. Это происходит из необходимости глобального мира постоянно изобретать всё новые и новые продукты интеллектуальной собственности, технологические и порой криминальные проекты, чтобы обойти уже существующие законы, цены и патенты, что в разы удорожает конечный продукт, снижает его конкурентную способность и прибыльность реализации. Криминальных проектов при этом регистрируется всё больше, стоимость продуктов становится все выше. Их экологическая опасность не только в долгосрочной, но и в ближайшей перспективе не ясна и законодательно не безукоризненна.

По данным проведенного ФБР расследования, бывший топ менеджер германского химико-фармацевтического концерна Bayer AG в 2000-01гг участвовал в тайных переговорах с представителями других экспортёров для установления завышенных цен на американском рынке на резино-химические материалы ${ }^{178}$. Вследствие подобной политики многим американцам уже стали недоступны национальные лекарства, и они едут в Мексику за дешёвыми лекарствами-генериками. В ставшей уже классической книге австралийских учёных Питера Драгоса и Джона Бравайтера «Информационный феодализм»(2002) отмечается, что суммарные затраты на брендовые лекарства в США утроились за период с 1990 по 2000год с 40,3 до 121,8 млрд.\$ США ${ }^{179}$. В тоже время в России, по данным Комиссии по ценным бумагам и биржам США (SEK), в период с 1994 по 2005гг дочерняя компания«EliLilly»по

${ }^{178}$ Бывший топ менеджер BayerAG признался в участии в картельном сговоре по поддержанию высоких цен.Экономический вестник фармации.№12(82)декабрь 2004.С.21.

${ }^{179}$ The Dark side of Intellectual property//Social Sciences Research Network. Working Paper Series. URL pecypc:htpp://ssrn.com/ abstract $=110639$ (last revisited:January,18.2012). 
несуществующим торговым соглашениям перевела миллионы долларов на счета оффшорных компаний, связанных с высокопоставленными госслужащими. После того как коррупционная схема вскрылась, головная компания пять лет не предпринимала никаких шагов для её прекращения. В рамках поданного 20 декабря 2012г соглашения об урегулировании претензий в федеральный суд США компания «Eli Lilly» не признала, и не опровергла справедливость выдвинутых обвинений ${ }^{180}$. По данным того же источника в августе 2012 года другой фармгигант «Phizer» заплатил более 60 миллионов долларов штрафных санкций за подкуп госчиновников и врачей в Болгарии, Хорватии, Казахстане, России, Италии,Китае,Чехии и Сербии. В результате отсутствия подлинно национальной инновационной культуры среди врачей стран Европы и России стали возможными в этих странах псевдо инновации компаний «Eli Lilly» и «Phizer».

В современных экономических условиях приведённые обнародованные факты коррупции чиновников и врачей различных стран цинично трактуются США и её партнёрами как вклад в «инновационный» путь развития этих стран. С 22 августа 2012года в России вступила в силу норма, запрещающая использование информации о клинических и доклинических исследованиях оригинального препарата без согласия разработчика в течение 6 лет с даты государственной регистрации оригинального препарата(режим эксклюзивности данных). Введение защиты интеллектуальной собственности в режиме эксклюзивности данных фактически продлевает патентную защиту зарубежных изделий и препаратов, способствует их монополии на российском рынке, препятствует производству и реализации более дешевых генериков.

${ }^{180}$ Американский фармгигант заплатит 29,4 миллиона долларов за подкуп российских чиновников.[ Электронный ресурс].-Режим доступа:http://medportal.ru/mednovosti/news/2012/12/21/elililly/ 
Введение данной нормы в законодательство стало прямым следствием уступок на переговорах России при вступлении в ВТО, так как режим эксклюзивности является принципиально выгодным для иностранных участников рынка. Несмотря на понимание на ведомственном уровне необходимости законодательной доработки вступившей в силу нормы закона об эксклюзивности данных ${ }^{181}$, включая контекст её действия в рамках TRIPS, из-за отсутствия поддержки российских инновационных медицинских изделий и услуг их доступность для населения России закономерно ухудшается. На этот случай во многих западных странах действует режим ограничения эксклюзивности данных в пользу национальной защиты здоровья местного населения, что для России оказалось недостаточно актуальным.

На основании рассмотренных фактов, очевидно, что инновационный процесс определяется двойственной природой нововведений в качестве устойчиво воспроизводимых элементов общественной практики не только позитивного, но и негативного социально- культурного значения. При этом, инновационный процесс, как основа инновационного развития, выступает в форме прагматизации новых продуктов интеллектуально-законодательного производства, которые апробируются населением. Несмотря на негативный опыт апробации, последний часто игнорируется в государственно законодательной сфере, переоформляется в узаконенный и приносящий финансовую прибыль бизнес крупных российских и зарубежных компаний, вопреки интересам здоровья населения, в первую очередь населения РФ.В тоже время отсутствие инновационной культуры-одна из главных причин отрицательных последствий институализации инноваций.

${ }^{181}$ Борзова М.Вступление России в ВТО и регулирование фармрынка./Ж.Ремедиум. №11.,2012.,с.7-20. 
Наряду с прагматизацией и идеализацией важной формой инновационного процесса выступает трансляция нововведений в систему культурных норм и образцов, подлежащих воспроизводству в процессе их освоения новыми поколениями людей. В связи с этим в инновационном процессе России в современных условиях возрастает роль общественных институтов, образования, средств массовой информации и коммуникации, технологий управления интеллектуальной собственностью которые транслируют социально-корректную и позитивную динамику культуры, применение и обращение нововведений различных сфер общественной практики. 


\section{ГЛава 3.5. КУЛЬТУРА ИНТЕЛЛЕКТУАЛЬНОЙ СОБСТВЕННОСТИ В ВЫСШЕМ МЕДИЦИНСКОМ ПРОФЕССИОНАЛЬНОМ ОБРАЗОВАНИИ}

Как указано в Европейском руководстве разработки стратегии в области интеллектуальной собственности (ИС,2007) в странах с переходной экономикой, стратегия в области ИС определяется в значительной степени международными и региональными нормами, которые могут возлагать определенные обязательства на соответствующие страны, и она не может быть полностью навязана или внедрена извне. Только сама страна может и должна разработать детальную стратегию, отвечающую ее конкретным условиям, выделить необходимые ресурсы на достижение реальных результатов, а затем предпринять практические шаги по реализации разработанной стратегии.

Внимание развивающихся стран и стран с переходной экономикой привлекает идея структурированного и планового подхода для извлечения максимальной выгоды от инновационной и творческой деятельности граждан, от привлечения внутренних инвестиций и установления делового сотрудничества с компаниями из стран с более развитой рыночной экономикой 182.

В рамках реализации практических шагов стратегии и культуры развития ИС президентом России В.В. Путиным в статье «О наших экономических задачах»183 указано, что восстановления инновационного характера экономики необходимо начинать с университетов как центров фундаментальной науки и кадровой основы

${ }^{182}$ Примеры стратегий по ИС и инновациям. [Электронныйресурc].-Режимдоступа:http://eur-lex.europa.eu/ LexUriServ/ site /en /com/ 2007/ com 2007_0182en01. pdf on technology transfer.

${ }^{183}$ Путин В.В. «О наших экономических задачах» 29 января 2012 г.[Электронный ресурс].-Режим доступа:http://www.newsru.com/ russia/29jan2012/ecoputin.html 
инновационного развития. К 2020г. должно в России быть создано несколько университетов мирового класса по всему спектру современных материальных и социальных технологий. Для этого российскими исследовательскими университетами, на примере зарубежных конкурентов, планируется получение на научные разработки до 50\% от своего финансирования по разделу «Образование». В связи с этим неизбежно обострение конкуренции образовательных услуг и научных достижений среди российских университетов. При этом качество образовательных услуг включено в парадигму прогрессивного развития России.

Премьер-министром России Дмитрием Медведевым продекларирована парадигма четырёх «И» прогрессивного развития России: инфраструктура, институты, инновации, инвестиции. Применительно к объявленной идее культуры прогрессивного развития эта парадигма может работать, если будет дополнена главным-социальной ценностью людей профессии, «..своей деятельностью прямо создающих социальный результат, а не косвенно, опосредовано-через налоги» ${ }^{184}$. Для достижения социально-желаемого результата процесса инноваций важна культура компетенций участников инноваций. На самом деле для успешного осуществления модернизации здравоохранения в масштабах страны в университетской сфере необходимо заранее формировать слой специалистов необходимой квалификации, образованности и изобретательности, способных осуществить этот сдвиг через свою инициативность, изобретательство, участие в работе профессиональных врачебных сообществ и общественных организаций.

Инновации-существенный элемент образования и самообразования студентов и врачей- выражаются в тенденциях накопления и видоизменения разнообразных культурно-творческих инициатив и нововведений в образовательном процессе, которые в совокупности приводят

${ }^{184}$ Тихомиров А.В.Законодательные проблемы регулирования рынка медицинских услуг.Ж.Российская юстиция.№5.2010. 
к изменениям в сфере образования и трансформациям его содержания в качество новое знание и расширенное культурно-информационное образовательное пространство. Рост культуры информации делает Интернет всё более привлекательным образовательным пространством для целевых аудиторий. По данным исследования MEDI-Q«Мнение практикующих врачей» проведённого компанией «КОМКОМ-Фарма» в 22 крупных городах России среди 2898 врачей 6 специальностей, количество использующих Интернет в профессиональной деятельности существенно возросло за 10 летний период времени 1999-2009гг с 3,5\% до 49\%. Оказалось, каждый 2-й из опрошенных врачей в той или иной мере использует Интернет. Рейтинг врачей работающих в интернете возглавили эндокринологи (60,6\%), урологи(59,5\%), аллергологи(58,7\%) и пульмонологи(58\%). Среди врачей других специальностей-терапевтов, кардиологов, неврологов, педиатров, впереди других интернет пользователей оказались терапевты-43,8\%. Таким образом, интернет образовательный ресурс достаточно широко используется в самообразовании специалистами эндокринологами и терапевтами, чаще всего сталкивающимися с сахарным диабетом и его нейрососудистыми осложнениями актуальными внутри и вне России.

Основная масса руководителей учебных заведений сознаёт необходимость значительных качественных изменений в системе образования. Не достаточность инновационных процессов в образовании во многом связано с отсутствием инноваций в культурно творческой деятельности. Хотя можно отметить тенденции повышения интенсивности и эффективности инновационной деятельности в системе образования. Однако субъекты этой деятельности недостаточно владеют соответствующими технологиями культуры инновационной деятельности и её реализации в инновации ${ }^{185}$.

${ }^{185}$ Приходько В.М. Образование: ракурсы и грани. Вестник высшей школы №10 (ноябрь 2010).С.11-23 
Важнейшим результатом внедрения инновационной культуры в образовательный процесс выступает консолидация интеллектуального потенциала социальной системы и общественных возможностей. Принятая в ноябре-декабре 1999 года в Ульяновске и Москве Национальная хартия инновационной культуры, под которой поставили подписи представители науки, культуры, образования, органов управления, деловых кругов различных регионов России, стала первым общественным программным документом, концентрированно отражающим задачи в этой области и пути их решения. На ее реализацию направлена деятельность Института стратегических инноваций и Комитета по инновационной культуре Комиссии РФ по делам ЮНЕСКО.

Существует неограниченный диапазон проявления инновационной культуротворческой деятельности - от создания условий эффективного использования инновационного потенциала личности, предприятия, организации в интересах развития общества до обеспечения максимальной взвешенности в его реформировании. С участием инновационной культуры реально в сфере конкретной экономики - добиться ускорения и повышения эффективности внедрения новых технологий и изобретений, в сфере управления - реального противодействия бюрократическим тенденциям, в сфере образования - содействия раскрытию инновационного потенциала личности и его реализации, в сфере культуры - оптимизации соотношения между традициями и обновлением, различными типами и видами культур ${ }^{186 . М и р о в о и ̆ ~ о п ы т ~}$ свидетельствует о том, что преодолеть экономическую стагнацию только с помощью государственных инвестиций невозможно. Так, по мнению комиссии европейских

${ }^{186}$ Николаев А.Н. Инновационное развитие и инновационная культура. [Электронный ресурс].-Режим доступа: http://vasilievaa. narod.ru/ptpu/9_5_01.htm

Варнеке Х.Ю. Причины успеха преуспевающих предприятий 
экспертов, изложенному в “Зеленой книге” в 1995 году, состояние инноваций в Европейском Союзе оценивалось как неудовлетворительное. Эта оценка во многом было связана со склонностью предприятий уходить от риска, а также с многочисленными препятствиями на пути творчества новаторов, канцелярщиной и волокитой. Подобные помехи существуют сегодня также и в России, отрицательно влияя на координацию усилий, людские ресурсы и правовую среду, что в итоге ограничивает возможности превращения научных прорывов и технологических достижений в коммерческий успех. В компании IBM вопрос производственной бюрократии решен следующим образом. Руководство IBM строго придерживается принципа трехлетней ротации сотрудников управленческого звена. Управленческие должности почти никогда не занимают люди, для которых «аппаратная работа» является основной профессией, почти всегда только рядовые сотрудники. Если кто-то в ходе ротации попадает в центральный аппарат, то он знает, что через три года снова вернется на прежнее место. Это - действенная гарантия от возникновения сложных систем. Ведь тот, кто знает, что через 36 месяцев опять вернется на прежнее место обычного сотрудника, в период своего краткого пребывания на управленческой должности не будет создавать мощной бюрократической системы (Питерс, 1982 г.).

Таким образом, социальную роль инновационной культуры в экономике и образовании, трудно переоценить. Известный менеджер, президент Фраунхоферского общества ФРГ, профессор Х.Ю. Варнеке ${ }^{187}$ считает, что практически все конечные цели, такие как увеличение сегмента рынка и улучшение качества продукции, лучше всего

${ }^{187}$ Varneke Kh.-Yu. Revolyutsiya v predprinimatel'skoy kul'ture [Revolution in entrepre-neurial culture]. Available at: http://transfer. eltech.ru/innov/archive.nsf 
достигаются посредством стратегий, воздействующих на социальную систему. В литературе, посвященной анализу модернизационных процессов социальной системы, выделяют ряд социокультурных факторов, определяющих возможность и успешность модернизационных процессов. Главный среди них-человеческий капитал. Необходимость социальной модернизации «человеческого капитала» не вызывает сомнений в экспертно- исследовательских кругах. Не решен вопрос о том, насколько она возможна в каждом конкретном случае и в отдельно взятой стране. Ответ ищется в рамках различных подходов, включая образовательный. По уровню образования Россия попадает в один кластер с такими странами, как Великобритания, Швеция, Финляндия, Япония (Рис.3.1).

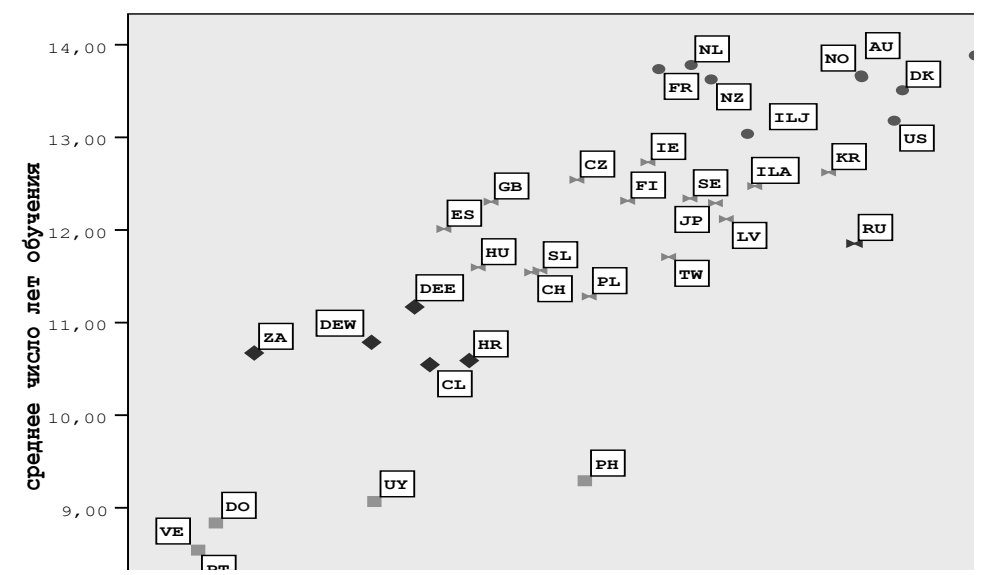

Puc.3.1. Мировой рейтинг уровня образования (Исследование ISSP (International Social Survey Programme 20062).

Хотя среднее число лет, проведенных российскими учащимися в учебных заведениях несколько ниже, чем для большинства развитых стран, тем не менее, по доле выпускников, получивших сертификат о «среднем и выше» 
образовании, Россия входит в пятерку лидеров. Например, в Великобритании, где учащиеся в среднем проводят в школах более 12 лет, доля сертификатов о «вторичном и выше» образовании составляет 31\%, в России, где средний показатель «школьных» лет ниже примерно на полгода, доля сертификатов о «среднем и выше образовании» достигает 51\%. Формальные показатели квалификации рабочей силы, сопоставленные по кодификатору ISCO-88, также позволяют отнести Россию к группе, если не лидеров, то «вполне успешных». Однако структура образовательных знаний и умений по вопросам интеллектуальной собственности среди студентов российских ВУЗов, в особенности медицинского профиля, не достаточно развита и практически не изучена.

Целью исследования была оценка характера образовательных знаний по вопросам интеллектуальной собственности среди студентов выпускного курса Волгоградского государственного медицинского университета.

Материалы и методы. Проведено анкетирование методом гнездовых выборок 603 студентов 3-х выпускных курсов 2009-11 гг лечебного факультета медицинского университета города Волгограда. Все участники выражали добровольное информированное согласие на участие в исследовании. Для анкетирования была разработана анонимная анкета с 11 вопросами, определяющая информированность студентов об объектах интеллектуальной собственности, наличия данного блока знаний и необходимость его включения в образовательный процесс. В мае 2010-11годов проведено исследование анкетой дополненной 4 вопросами по интеллектуальной собственности изложенными в IV части ГК РФ. Результаты опроса 173 студентов 2010 года по совпадающим 11 вопросам первоначально разработанной анкеты изучены в сравнительном аспекте с данными анкетирования 
217 студентов 2009 года. Статистическую достоверность качественных различий данных анкетирования 20092010 гг оценивали с помощью многофункционального

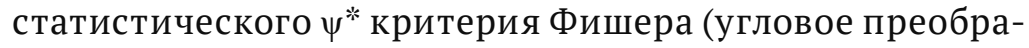
зование Фишера). Статистически достоверным считали значения: $\psi^{*}=1,64$ при $p<0,05 ; \psi^{*}=2,31$ при $p<0,01 ; \psi^{*}=2,81$ при $\mathrm{p}<0,001$.

\section{Полученные результаты}

Всего опрошено 603 студента, из них 380 студенток и 223 студента.

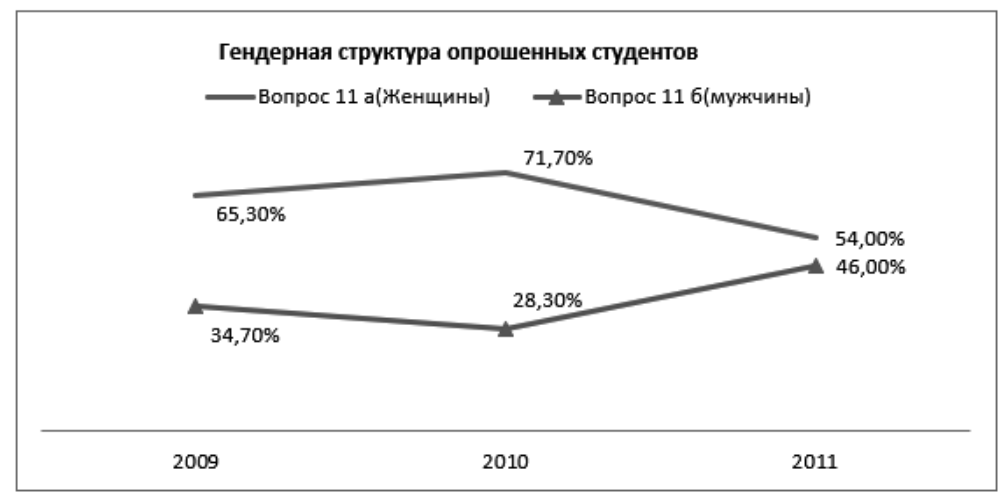

Рис.3.2. Гендерная структура интервьюированных студентов

В 2011 году количество опрошенных студентов мужчин увеличилось на 17,7\% в сравнении с 2010 годом, и на $11,3 \%$ в сравнении с 2009 -годом, однако не превысила $46 \%$ (рис 3.2.).

По полученным данным в 2009 году нечего не знали о каких-либо патентованных разработках в вопросах кардиологии и эндокринологии $52,3 \%$ опрошенных студентов. В 2010г (72,8\%) и 2011г (72,8\%) достоверно $(\mathrm{p}<0,05)$, ,больше в сравнении с 2009 годом (Рис 3.3). 


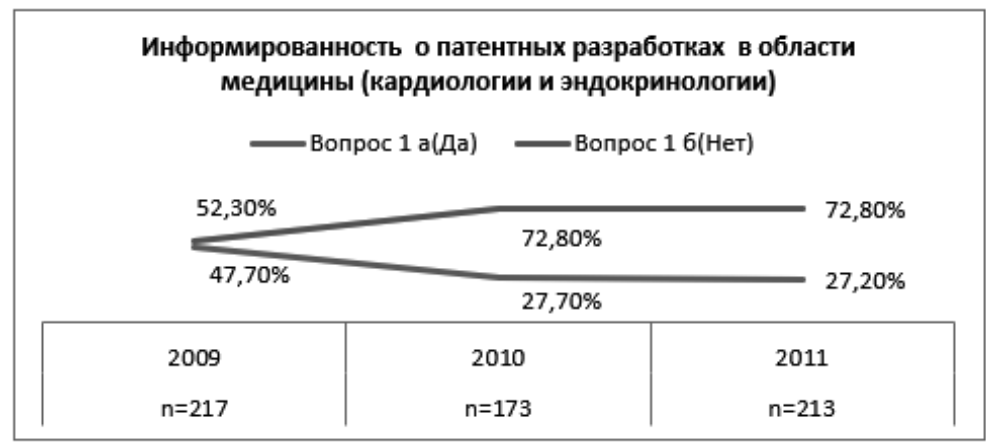

Рис. 3.3 Информированность студентов о патентных разработках в области медицины

Не использовали патентованные разработки при подготовке к практическим и семинарским занятиям 71,3\% в 2009 году, 87,9\% в 2010 году ( $<<0,01), 77,9 \%$ в 2011 году опрошенных студентов, что объясняется прямым снижением информированности студентов о патентных разработках в 2010 и 2011гг на $27,7 \%$ и $27,2 \%$, соответственно (рис 3.4.).

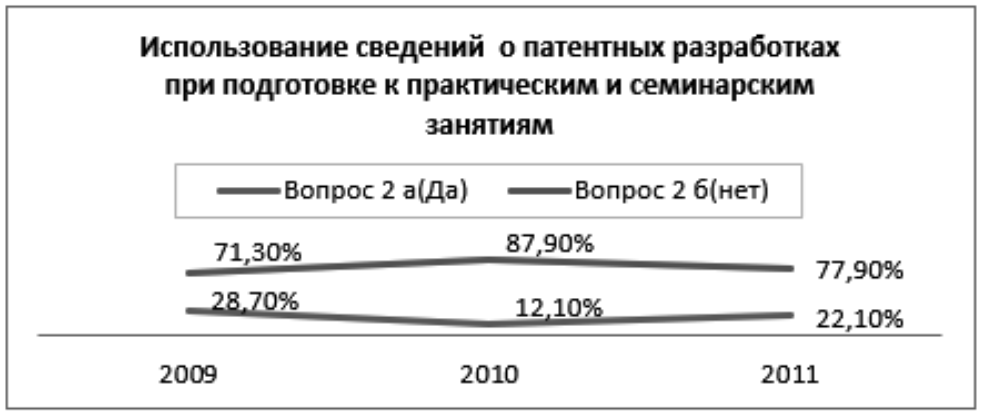

Рис.3.4. Частота использования сведений о патентных разработках при самоподготовке студентов

$45,8 \%$ студентов 2009 года и $48,8 \%$ студентов выпускников 2011 года ничего не знали о возможностях патентной 
охраны результатов интеллектуальной деятельности в качестве изобретений, полезных моделей и программных продуктов. В 2010 году информированность студентов о возможностях патентной охраны результатов интеллектуальной деятельности выросла до 60,7\% в равнении с 2009г (54,2\%), а в 2011г вновь снизилась до51,1\% (рис.3.5). Таким образом, более $1 / 2$ студентов не имеют представления о возможностях патентной охраны результатов интеллектуальной деятельности.

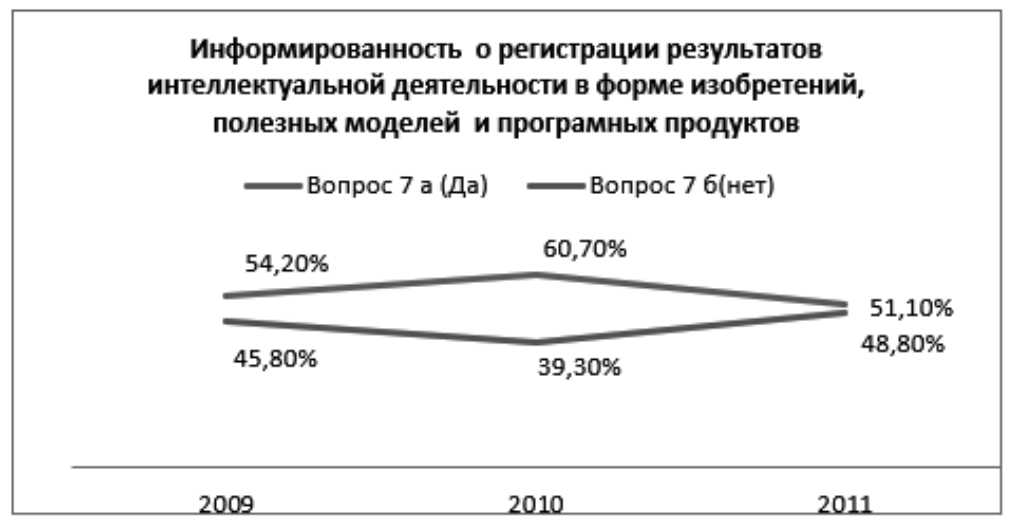

Рисунок 3.5.Информированность студентов о возможностях регистрации результатов интеллектуальной деятельности

Материальное вознаграждение за изобретательство в медицине в 2009 году считало достаточным и не совсем недостаточным менее трети опрошенных (5,6\% и 20,8\%), а в 2010 году чуть больше $1 / 3$ студентов (5,2\% и 27,7\%;р>0,05), при этом годовая структура мнений в этом вопросе существенно не изменилась. Затруднились ответить на данный вопрос 26,9\% студентов в 2009 году и достоверно меньше 17,3\% (p<0,01) студентов в 2010 году. Недостаточность материального вознаграждения за изобретательство отметили 
$46,8 \%$ опрошенных в 2009,50,3\% в 2010году, 38\% в 2011 году(рис3.6).

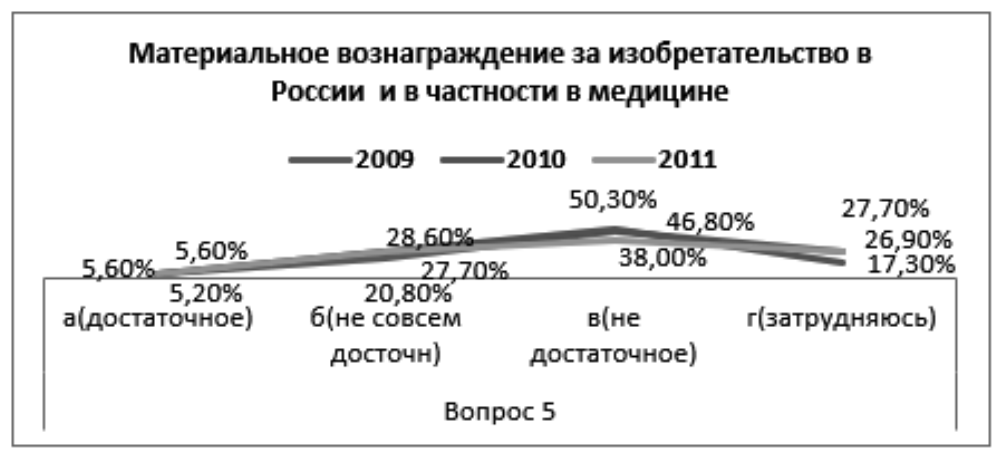

Рис.3.6.Характер материального вознаграждения за изобретательство в российской медицине

Несмотря на одинаково неблагоприятную конъюнктуру ответа достаточного материального вознаграждения за изобретательство среди выпускников 2009, 2010 и 2011 годов ( $\approx 5,5 \%)$ показатель престижности занятия изобретательством оказался самым низким в 2011 году $(18,7 \% ; 38,4 \% ; 42,2 \%$ p $<0,05)$.Ситуацию несколько смягчила структура наиболее частого ответа не очень престижного характера занятия изобретательством среди выпускников 2011 года в сравнении с 2009 и 2010гг ( $38,2 \%$ vs $26,4 \%$ и $30 \%$, соответственно, $\mathrm{p}>0,05)$. Таким образом, в 2011 году среди студентов отмечен рост отношения к изобретательству как к не очень престижному виду занятия. Одновременно среди студентов 2009-11 годов отмечен рост мнения не престижности занятия изобретательством (6,5-13,3-16,9\%; р>0,05). При этом существенной динамики в структуре затруднявшихся дать ответ в 2009-11 гг. не обнаружено $(27,8 \% ; 13,3 \%$;и $26,3 \%$ соответственно. Рис 3.7.). 


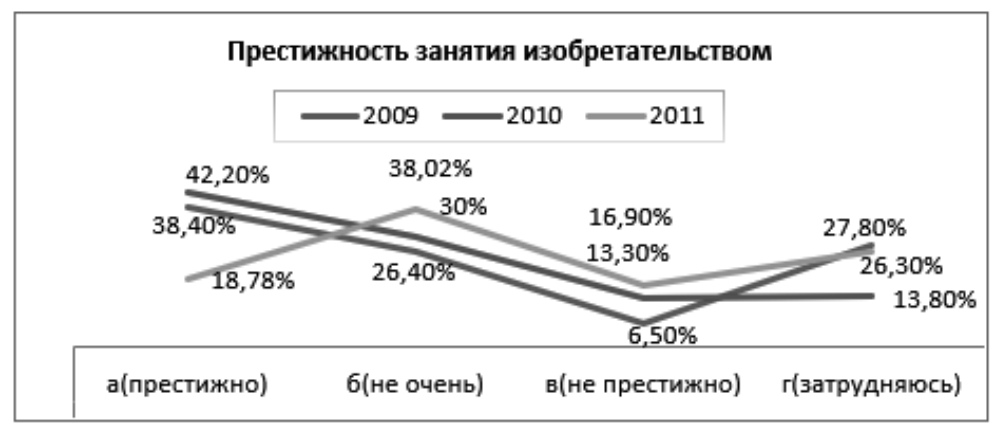

Рис 3.7. 3-х летняя структура престижности занятия изобретательством студентов

На вопрос наличия «безусловно или частично» всех возможностей у молодежи для занятий изобретательством (в частности в медицине) положительно ответили $44 \%(13,4 \%$ и 30,6\%) респондентов 2009 года, 50,3\% (14,45\% и $35,83 \%$ р>0,05) респондентов 2010 года и 50,7\% (14,1\% и 36,6\%) респондентов 2011 года. Таким образом, в 2010-11гг не менее 50\% студентов отметили наличие среди молодежи «безусловно или частично» всех возможностей для занятий изобретательством (в частности в медицине).

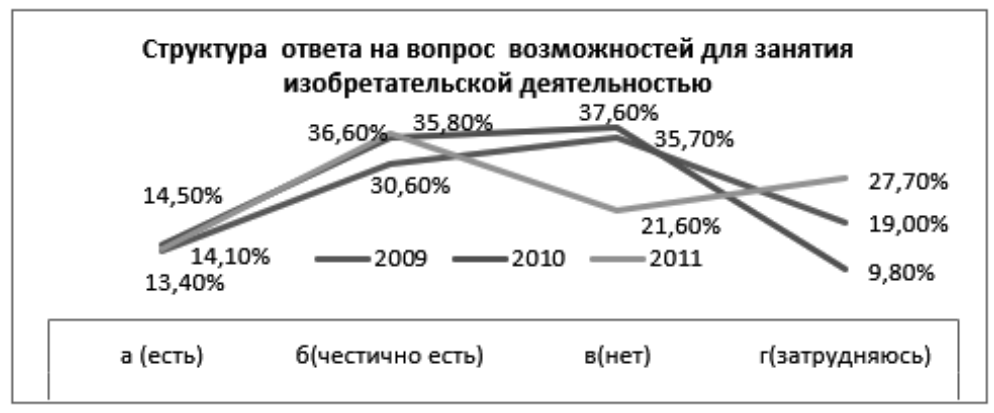

Рис 3.8. 3-х летняя структура возможностей для занятий изобретательством студентов 
При анализе структуры ответов наличия всех возможностей для занятия изобретательством $35,7 \%$ студентов 2009 года,37,6\% 2010года и21,6\% 2011года, не нашли возможностей для занятия им.

Уверенный и недостаточно уверенный ответ на вопрос какого-либо интереса к изобретательской деятельности дали $37,5 \%$ и 29,6\% студентов 2009 года, $27,2 \%$ ( $\left.\mathrm{p}_{9,10}<0,05\right)$ и $37,6 \%\left(\mathrm{p}_{9,10}<0,05\right) 2010$ года, $27,8 \%$ и $39,0 \%$ 2011года (Рис.3.9.).

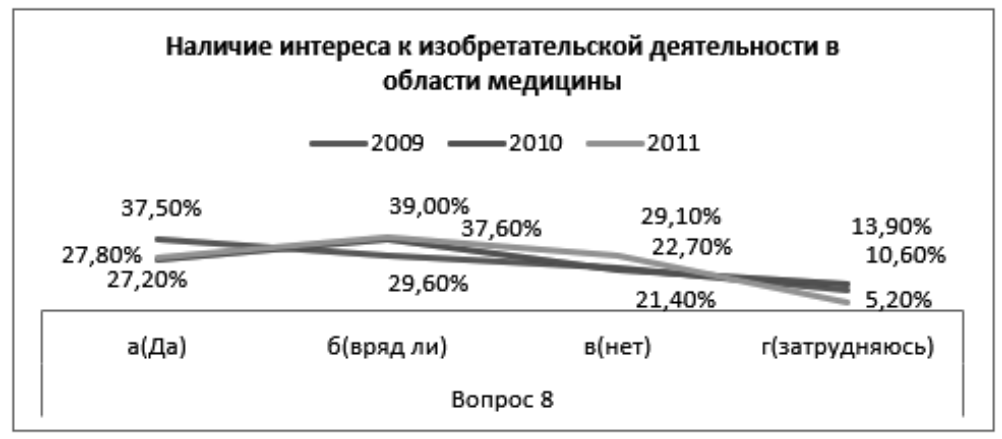

Рис 3.9. Интерес к изобретательской деятельности среди студентов

При этом за 3-х летний период 2009-2011гг неуверенный интерес к занятию изобретательством среди студентов возрос $\left(29,6-37,6-39,0 \% ; p_{9,11}<0,05\right)$, а уверенный интерес снизился $\left(37,5-27,2-27,8 \% ; \mathrm{p}_{9,10}<0,05\right)$.При этом отрицание какого-либо интереса к 2011 году возросло (22,721,4-29,1\%).

Таким образом, за 3 исследованных года выявлена потеря явного интереса студентов к занятию изобретательством на фоне сохранения неуверенного интереса к изобретательской деятельности.

При анализе ответов П. «а» ответа на вопрос №8(наличие интереса к занятиям изобретательской деятельностью) и п/п «б» ответа на вопроса №4(практическое 
отсутствие возможностей для занятия изобретательством) преобладание интереса над возможностями отмечено в ответах студентов 2009 и 2011гг. (Рис.3.10).
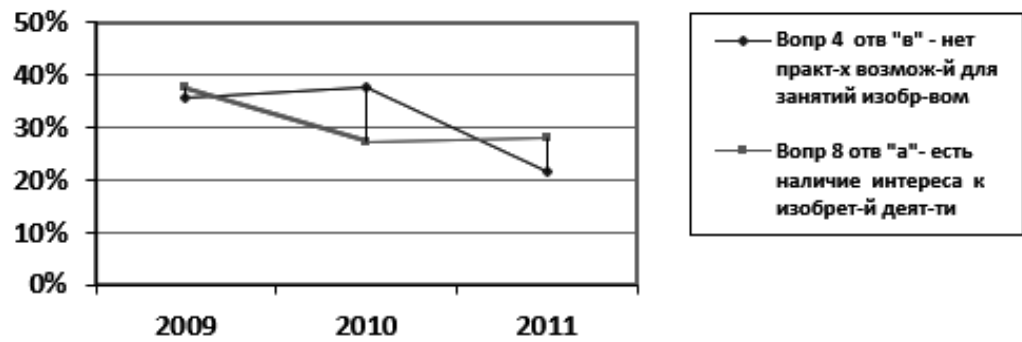

Рис.3.10. 3-х летняя структура наличия возможностей и интереса $к$ занятиям изобретательством среди студентов

Обращает на себя внимание отсутствие лимита интереса к занятию изобретательством несмотря на отсутствие возможностей для занятий изобретательством среди студентов 2011 года (интерес на 6,2\% выше возможностей) и среди студентов 2009года(интерес на 1,8\% выше возможностей). Только в 2010 году интерес к занятию изобретательством оказался лимитирован отсутствием возможностей для занятий изобретательством (интерес на10,4\% ниже отсутствия возможностей). Учитывая, что возможности для занятий изобретательством реализуются через участие в работе СНО, лимит возможностей мог быть обусловлен недостаточно активным участием студентов в работе СНО. Действительно, в 2010 году в сравнении с 2009 и 2011гг, конъюнктура посещений студентами 1-го и более студенческих научных кружков была наименее благоприятной (рис.3.11). 


\section{Вопрос занятости в студенческом научном кружке}

Bonpoc 10 a(не состою)

— Bопрос 10 6(состою в 1кружке)

-Bопрос 10 в(состою в 2-х и более)

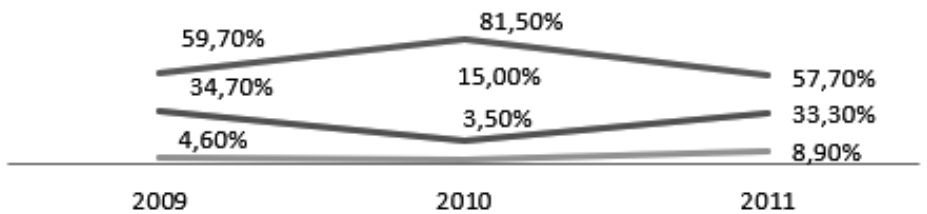

Рис 3.11.Структура занятости студентов в СНО

В 2010 году отмечено снижение числа студентов посещавших один(15,02\%; 34,7\%; 33,3\%; $\left.\mathrm{p}_{10,09}<0,01 ; \mathrm{p}_{10,11}<0,01\right)$ или два студенческих научных кружка (3,5 и 8,9\% $\left.\mathrm{p}_{10,11}<0,05\right)$.

В 2009 году 10,6\% респондентов затруднились ответить на вопрос анкеты №8 «Наличие интереса к занятиям изобретательской деятельностью» и $22,7 \%$ не проявили никакого интереса к занятиям. Аналогичным образом распределились ответы респондентов в 2010 году-13,87\% и 21,38\%,соответственно. В 2011 году структура ответов изменилась. В5,2\% случаев отмечено затруднение при ответе и в $29,1 \%$ отсутствие интереса к изобретательской деятельности (Рис 3.12.).

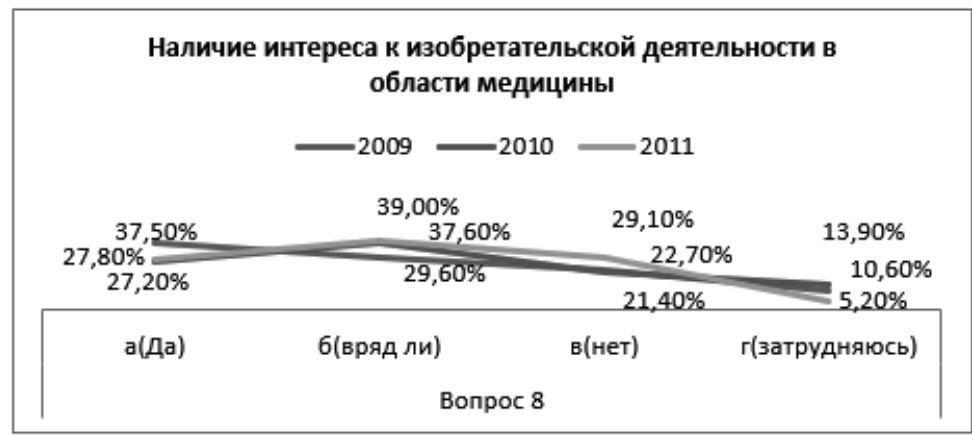

Рис 3.12.Структура интереса к изобретательской деятельности среди студентов 2009-11г2. 
На вопрос №9 анкеты занятостью какой-либо изобретательской деятельностью (например, в студенческом научном кружке) отрицательный ответ в 2009 году дали 67,13\%, положительно ответили 30,1\% (рис.3.13).

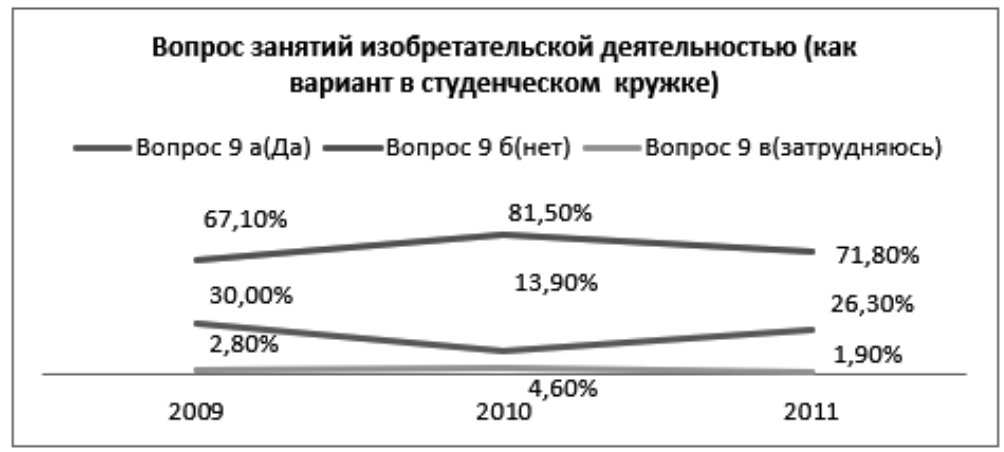

Рис 3.13.Частота занятий изобретательством среди студентов выпускников ВолгГМУ

При этом \% занятости студентов в работе СНO составил 39,3(\% посещавших научные кружки). То есть 76,6\% $(30,1 / 39,1)$ студентов 2009 г занятых в CHO занимались изобретательством.

В 2010 году число отрицательных $\left(81,5 \% ; p_{9,10}<0,01\right)$ и положительных $\left(13,87 \% ; p_{9,10}<0,01\right)$ ответов оказалась больше и меньше в сравнении с 2009 годом. При этом \% занятости в работе СНО составил 18,5 . То есть $74,9 \%$ студентов 2010 года занятых в СНО занимались изобретательством.

В 2011 году \% занятости студентов в работе СНО составил 42,2. Показатель занятий изобретательством в СНО составил 26,3\%. Отсюда62,3\% $(26,3 / 42,2)$ студентов 2011 года занятых в СНО занимались изобретательством. Таким образом, в 2009-11гг выявлена тенденция снижения занятий изобретательством среди студентов выпускного курса, работавших в этот период времени в СНО ВолгГМУ (рис.3.14.). 

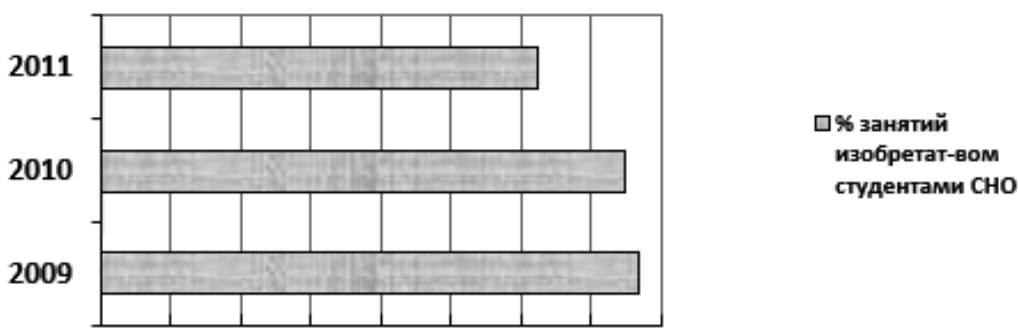

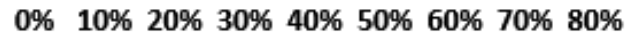

Рис.3.14. 3-х летний тренд занятий изобретательством студентов работающих в СНО

На вопрос №3 анкеты о целесообразности включения вопросов создания и патентования объектов интеллектуальной собственности в образовательные программы высшего профессионального образования положительно ответили 51\% студентов 2009года, 41\% 2010года и 38,0\% 2011года.При этом в 2009году 16,7\% студентов не были согласны с целесообразностью включения вопросов создания и патентования объектов интеллектуальной собственности в образовательные программы, 12,3\% в 2010году, 24,4\% в 2011году(Рис.3.15).

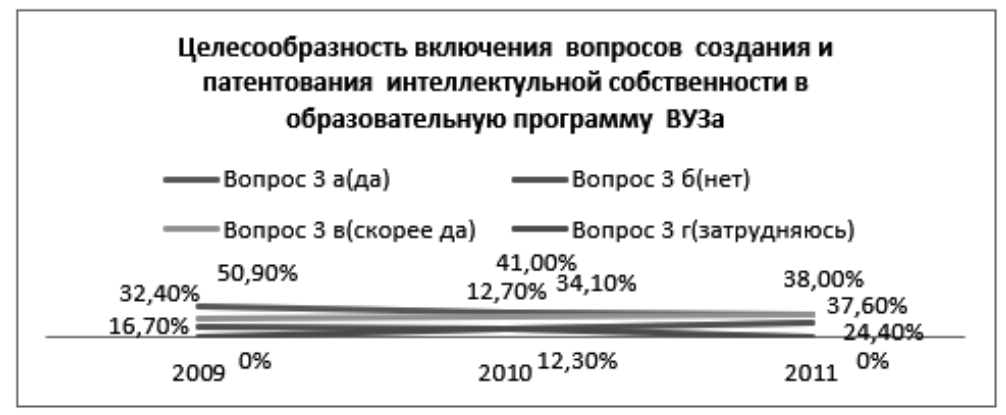

Рис.3.15.Целесообразность включения вопросов создания и коммерциализации ИС в образовательный процесс ВУЗа 
Падение образовательного интереса к объектам ИС, образовательным программам по объектам ИС объясняется динамичным снижением в 2009-2011ггколичества студентов активно занимавшихся изобретательской деятельностью в СНО.

Другие, ниже рассмотренные вопросы анкетирования анализировались по данным опроса студентов 2010 и 2011 года, так как были разработаны и включены в анкету позднее 2009 года.

В 2010-11 годах на вопрос анкеты «Должны ли изобретения отвечать общественным интересам, принципам гуманности и морали?» ответили «да» и «скорее да» $88,4 \%$ $(71,7 \%+16,8 \%)$ и $61,1 \%(40,4 \%+20,7 \%)$ опрошенных студентов. Отрицательный и неуверенный отрицательный (скорее нет) ответ отмечен в $6,35 \%(5,2 \%+1,15 \%)$ и $4,8 \%(3,4 \%+1,4 \%)$ случаев, соответственно. Затруднения с ответом возникли у 3,5\% и 28,6\% студентов, соответствующих лет(Рис.3.16).

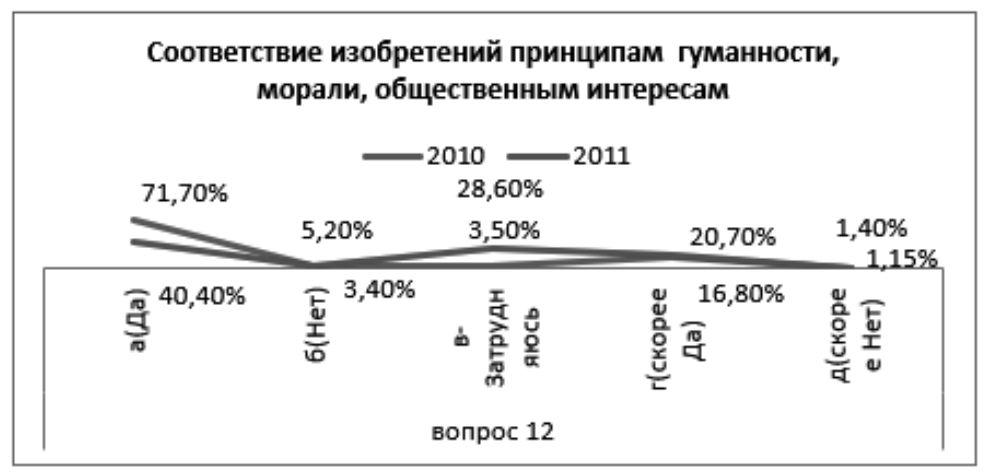

Рис 3.16.Знание соответствия условий регистрации объектов ИС требованиям законодательства

Знание раздела ГК РФ регламентирующего вопросы ИС отметили 9,8\% и 14,4\%студентов 2010 и 2011 гг, соответственно. Затруднились ответить $20 \%$ и $12,5 \%$.Не знали раздела ГК регламентирующего обращение ИС 70,1\% и 
71,6\% студентов 2010 и 2011гг (рис.3.17).Обращает на себя внимание не знание более чем $70 \%$ студентов раздела ГК регламентирующего обращение объектов ИС.

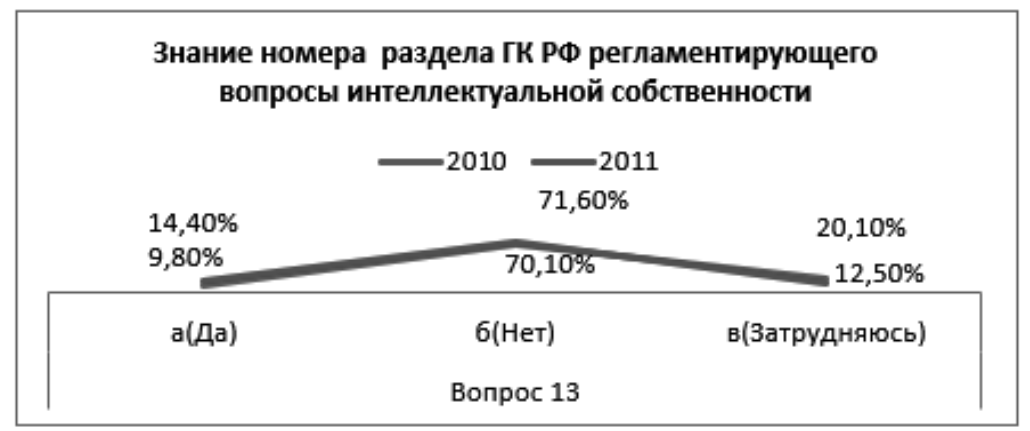

Рис 3.17.Знание раздела ГК РФ регулирующего оборот объектов ИС

Неограниченный срок охраны авторства ИС отметили $16,7 \%$ и 18,3\% студентов 2010г и 2011г, соответственно. Ограничение срока охраны авторства и имени автора интеллектуальной собственности отметили 31,8\% и 12,1\%, затруднились дать ответ 52\% и 69,7\% (рис.3.18).

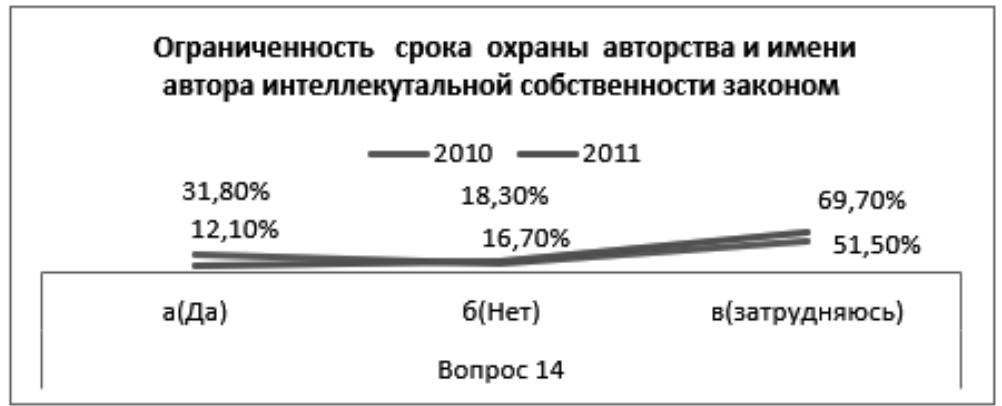

Рис 3.18.Знание сроков охраны авторства и имени автора ИС

Обращает на себя внимание низкий \% знаний сроков охраны авторства ИС менее чем $1 / 5$ студентов и 
фактическое незнание (затруднение ответа +незнаниеответа) срока охраны авторства ИС свыше 80\% (83,3\% и 81,8,0\%)опрошенных студентов.

Не отделяли авторское право от произведений науки, литературы и искусства (ответы «да»+«скорее да») в 20102011 гг $82,1 \%$ (57,60\% и 25,43\%) и лишь 46,0\% (35,2\% и 10,8\%), соответственно. Уменьшение показателя вдвое свидетельствует о снижении образовательных компетенций в вопросах авторского права среди выпускников 2011года.

Отделили авторское право (ответы «нет»+ «затрудняюсь») от произведений относимых к объектам ИС в 2010-2011 году 17,9\% и 54,0\% студентов, соответственно. (рис.3.19).3-х кратный рост числа студентов в 2011 году отделивших авторское право от объектов ИС может свидетельствовать не только о критически угрожающем состоянии образовательных компетенций, но и о недостаточно высоком качестве получаемого образования.

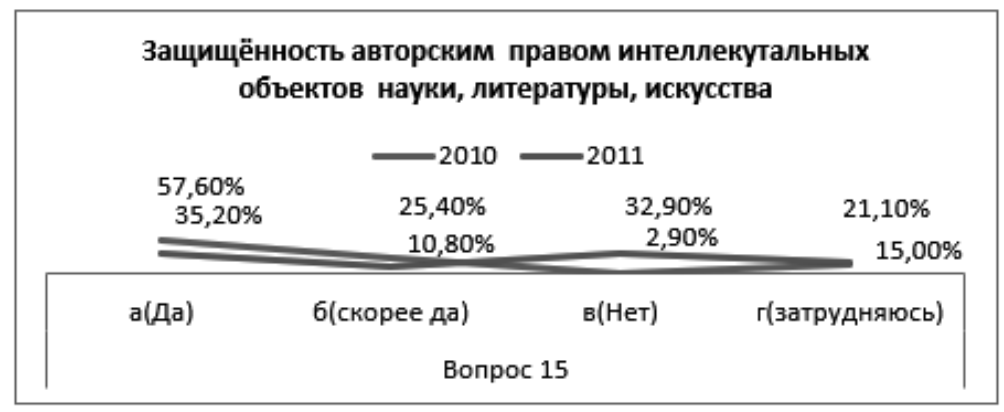

Рис. 3.19. Информированность студентов о защищенности объектов авторского права

Таким образом, среди студентов выпускников 2011 года более половины не образованы в кардинальном вопросе ИС-авторского права. 


\subsection{0бсуждение результатов}

Около 1/3 студентов выпускного курса проявляет интерес к процессу создания изобретений при работе в СНО и считает этот процесс престижным. В тоже время более $80 \%$ студентов демонстрируют правовую безграмотность в отношении знания номера раздела ГК РФ, регламентирующего вопросы интеллектуальной собственности. Обращает внимание снижение из года в год числа студентов выпускного курса, участвующих в работе СНО университета. Как показал опрос, большинство студентов не используют патентных разработок в образовательном процессе. Сегодняшние студенты недостаточно образованы и, поэтому недостаточно заинтересованы в применении доступных «know how» предметных знаний, патентовании творческих продуктов своей интеллектуальной деятельности и способов их коммерциализации, по причине недостаточной правовой грамотности и умений.

В спектре образовательных технологий дипломного и последипломного образования Волгоградского государственного медицинского университета технология решения изобретательских задач (ТРИЗ)представлена номинально. В тоже время среди студентов 2009 и 2011 гг. интерес к занятию изобретательством выше отсутствия у опрошенных возможностей. Фактический интерес для занятий изобретательством выше возможностей на 1,8\% и 6,2\% в 2009г и 2011г, соответственно.

Очевидно, что формирование «изобретательской» компетентности повышает конкурентоспособность и привлекательность образовательного процесса для студентов, актуализирует их мотивацию на процесс усвоения основных и дополнительных знаний. Правовая безграмотность молодых врачей происходит из-за 
недостаточной базовой подготовки в ВУЗе по вопросам разработки и правоприменения объектов интеллектуальной собственности. На курсе ПК ФУВ Волгоградского медицинского университета по педагогике при рассмотрении спектра современных образовательных технологий вопросы решения изобретательских задач не читаются и не изучаются. Кроме юридически-правой неграмотности врачебных кадров, их изобретательство тормозят внутренние противоречия между нормативным регулированием внедрений новых медицинских технологий и патентной активностью медицинских организаций, включая научно-исследовательские и образовательные. Патент подтверждает новизну, но при этом запрещает использование новой медицинской технологии без лицензионных платежей. В процессе регистрации в Росздравнадзоре любая медицинская технология перестает быть новой, так как может использоваться без ограничений всеми лицами, осуществляющими медицинскую деятельность в соответствии с законодательством Российской Федерации.

Приобретающему право использования исключительных прав в рамках лицензионного договора на новый способ лечения или диагностики нельзя этими правами воспользоваться без получения разрешения на практическое использование данных методов лечения. Такая громоздкая двух ступенчатая схема коммерциализации новых лечебных и диагностических технологий делает их менее привлекательными для внедрений и инвестирований по сравнению с разрешенными к применению, но без признаков новизны, поскольку предполагает дополнительные финансовые и временные затраты.

Необходимость поиска новых подходов к проблеме управления интеллектуальной собственностью в российской медицине обусловлена тем, что коммерциализация 
объектов ИС в сложившихся условиях может быть эффективна лишь в условиях чёткой и гибкой взаимосвязанности всех задействованных в коммерциализации ИС социально-государственных структур, профильных подразделений ВУЗов, НИИ, ТФОМС, административных органов региональной власти, медицинских организаций (Рис.3.20).

Если анализировать структуру заявок и патентов ФИПС, больше 50 \% патентов и заявок от медицинских образовательных и учебных заведений занимают технические решения на способы диагностики и лечения. При этом способы лечения и диагностики - это объекты, которым в Европе не предоставляется патентная охрана. Поэтому способы лечения и диагностики потенциально незащищены на рынке стран Европейского Союза. И их место на рынке России и стран бывшего СНГ.

Исходя из существующих нормативно-регламентирующих документов для практического применения новых медицинских технологий, возможного конфликта финансовых интересов между врачами-изобретателями и пациентами может быть использована следующая схема коммерциализации «бюджетных» разработок «knowhow" в ВУЗе и НИИ. Научные сотрудники учреждения разрабатывают новую медицинскую технологию, заявляют ее в Росздравнадзор, получают на нее разрешение, рассылают информацию о новой технологии заинтересованным в ее применении ЛПУ, проводят циклы обучения, оформляют нотариально заверенные разрешения на применение данной разработанной технологии, вносят представителей ЛПУ прошедших курс обучения по использованию новой технологии в реестр Росздравнадзора, несут юридическую ответственность за возможные негативные последствия её применения наряду с представителями ЛПУ, осуществляют дальнейшее консультирование по вопросам использования технологии. 
Для создания экономического механизма мотивации применения медицинских инноваций конкретным врачом необходим переход на финансирование по принципу полного фондодержания первичного звена с включением в состав подушевого норматива затрат на всю медицинскую помощь. В случае применения инноваций, включая патентные, врач амбулаторно-поликлинического звена может снизить расходы первичного звена путём внедрения патентных методов профилактики и лечения осложнений, в первую очередь, широко распространённой сердечно-сосудистой патологии. Важной проблемой использования и внедрения медицинских инноваций является реализация прав пациента на самостоятельный выбор первичной специализированной медицинской помощи. В п. 5 ч. 1 ст. 16 Закона № 326-ФЗ, ч. 1 и 2 ст. 21 Закона № 323-ФЗ закреплено право гражданина на выбор врача. Тем самым созданы условия для передачи функции заказчика медицинской услуги от врача непосредственно пациенту вместе с правом участия в распределении финансовых ресурсов системы ОМС (принцип «деньги следуют за пациентом») не по территориальному, а персонализированному принципу. 


\section{Схема институционального управления}

медицинскими разработками, включая врачебные

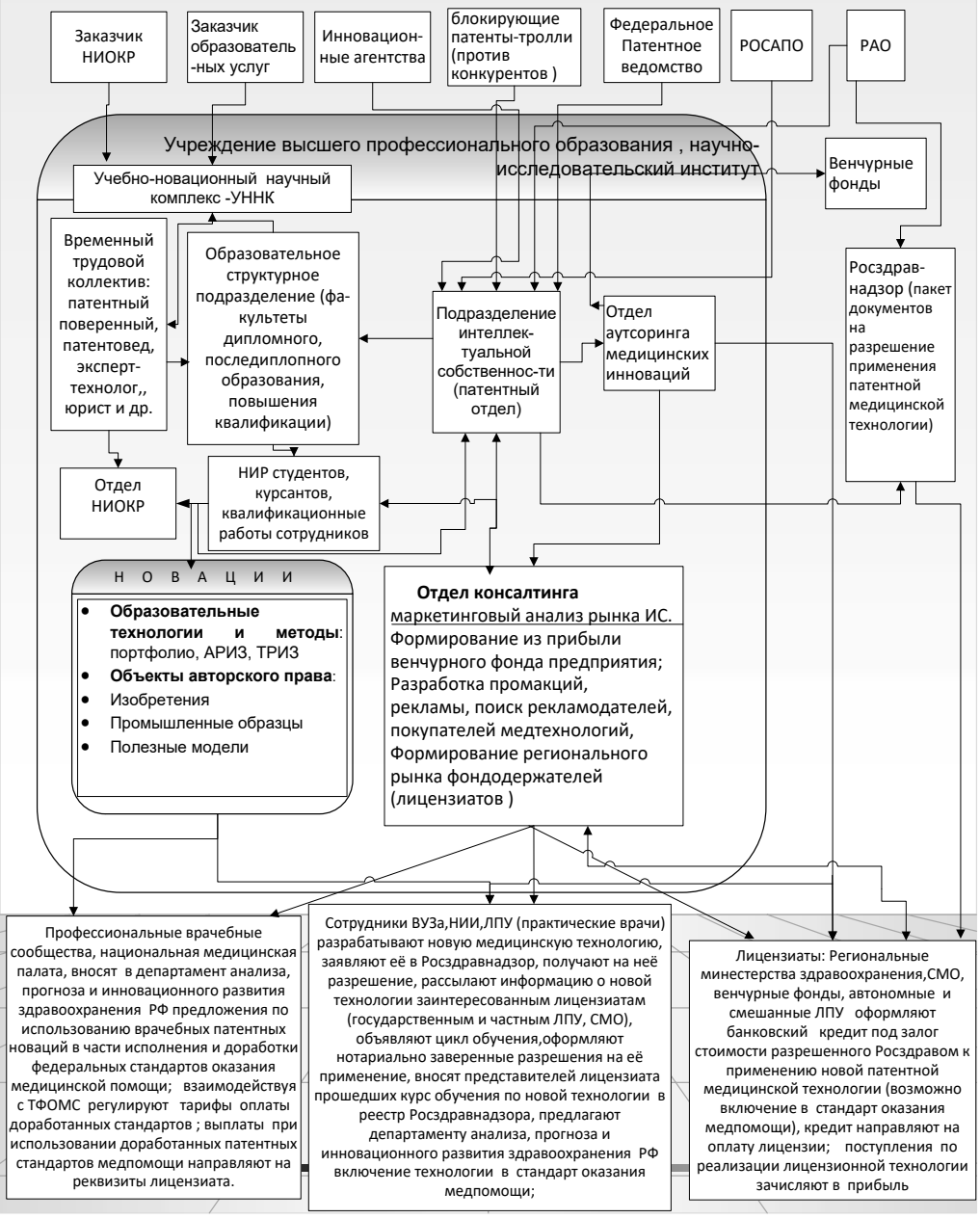

Рис. 3.20.Источник: составлено автором 
При этом закономерен вопрос экономически и клинически рационального распоряжения пациентом предоставленной свободы выбора в условиях несбалансированной дефицитности программы государственных гарантий бесплатной медицинской помощи и её финансового обеспечения. В условиях предоставления свободы выбора пациентом врача растут удельный вес дорогостоящих видов медицинских услуг, часто навязываемых пациенту вне ПГГ, а также общие затраты на оказание медицинской помощи и дефицит их покрытия из территориального фонда OMC. При этом повышается заинтересованность врачебных кадров в разработке и использовании собственных и представленных на рынке инновационных патентных медицинских технологий.

В связи с законодательно предоставляемой свободой рационального выбора пациентом бесплатной медицинской помощи, врачам необходим дополнительный объём знаний, который должен покрывать дефицитность гарантированно-бесплатных медицинских услуг путем применения отечественных патентных технологий. Учитывая актуальность вопросов ИС в модернизации здравоохранения России, а также принимая во внимание «опросные» мнения студентов выпускников медицинского университета о необходимости дополнительного блока знаний по ИС, разработке, регистрации, коммерциализации объектов интеллектуальной собственности и авторского права в изложении IV-й части ГК РФ, представляется целесообразным разработка и внедрение в образовательный процесс медицинского ВУЗа программ дополнительного образования по вопросам интеллектуальной собственности для студентов ВУЗа и врачей системы последипломной подготовки и повышения квалификации.

При производственном врачебном стаже от 10 лет представляется целесообразным формирование в 144 часовой программе переподготовки и повышения 
квалификации вопросов касающихся интеллектуальной собственности, технологий решения изобретательских задач. В случае конкурсного избрания на должность и/или планирования работником выполнения новых видов деятельности при врачебном стаже до 10 лет целесообразна подготовка по вопросам ИС, технологиям решения изобретательских задач, с акцентом на основы менеджмента ИС, инвестиционные технологии.

Повышать квалификацию по вопросам ИС у руководящих работников системы здравоохранения целесообразно на сертификационных циклах повышения квалификации по вопросам организации, управления и экономики здравоохранения с дополнительным знаний по вопросам ИС, технологиям решения изобретательских задач, инвестиционным технологиям. При проведении данного цикла важно чтобы программа включала следующие учебные модули:

Планирование и стратегическое управление материальными и нематериальными активами экономики здравоохранения.

Основы антикризисного управления; Инвестиционные технологии и инструменты; Информационное обеспечение; Методы экономического анализа, оценка программ и инвестиционных программ и проектов в сфере здравоохранения.

Окончательный выбор варианта услуги усовершенствования профессиональных знаний медицинских работников с частичным или полным отрывом от работы проводится в соответствии с общепринятыми формами усовершенствования в зависимости от производственного стажа, обязательств работодателя и индивидуальных предпочтений курсанта согласно схеме на рис.3.21. 


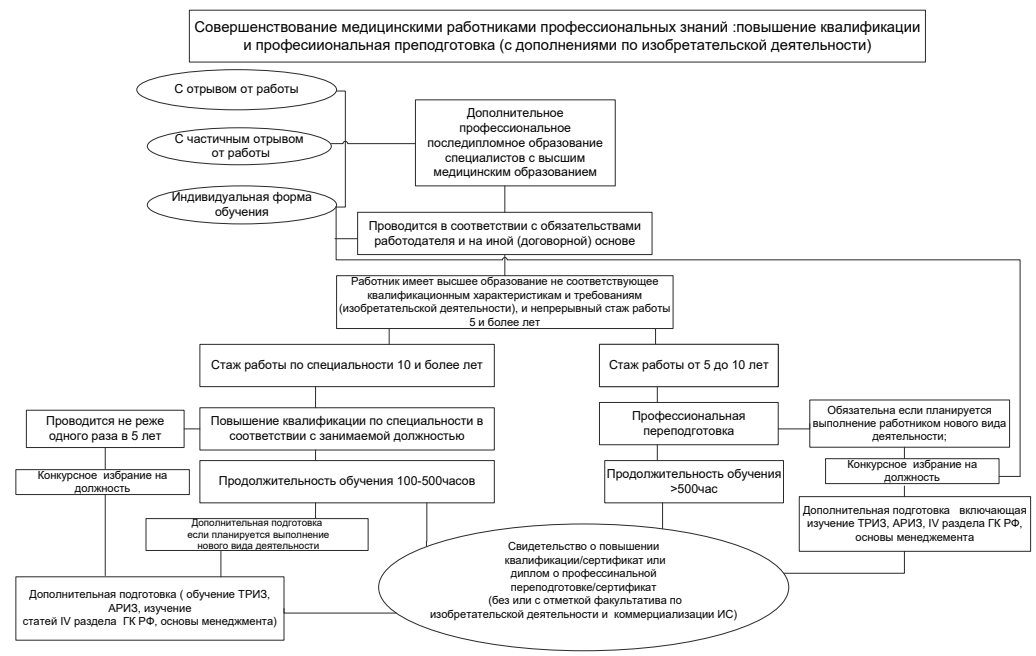

Рис.3.21.Схема усовершенствования медицинскими работниками профессиональных знаний по ИС Источник: составлено автором.

В плане реализации указанного образовательного проекта автором была подана заявка на конкурс государственных научных грантов Волгоградской области 2017$18 г г$ по проекту «Увеличение занятости неработающей части населения и содействие развитию всех форм бизнеса» (справка в приложении).

В существующей системе государственной поддержки инноваций корпоративных разработчиков инноваций, отстаётся не разработанным вопрос господдержки патентных разработок индивидуальных и самозанятых препринимателей. 


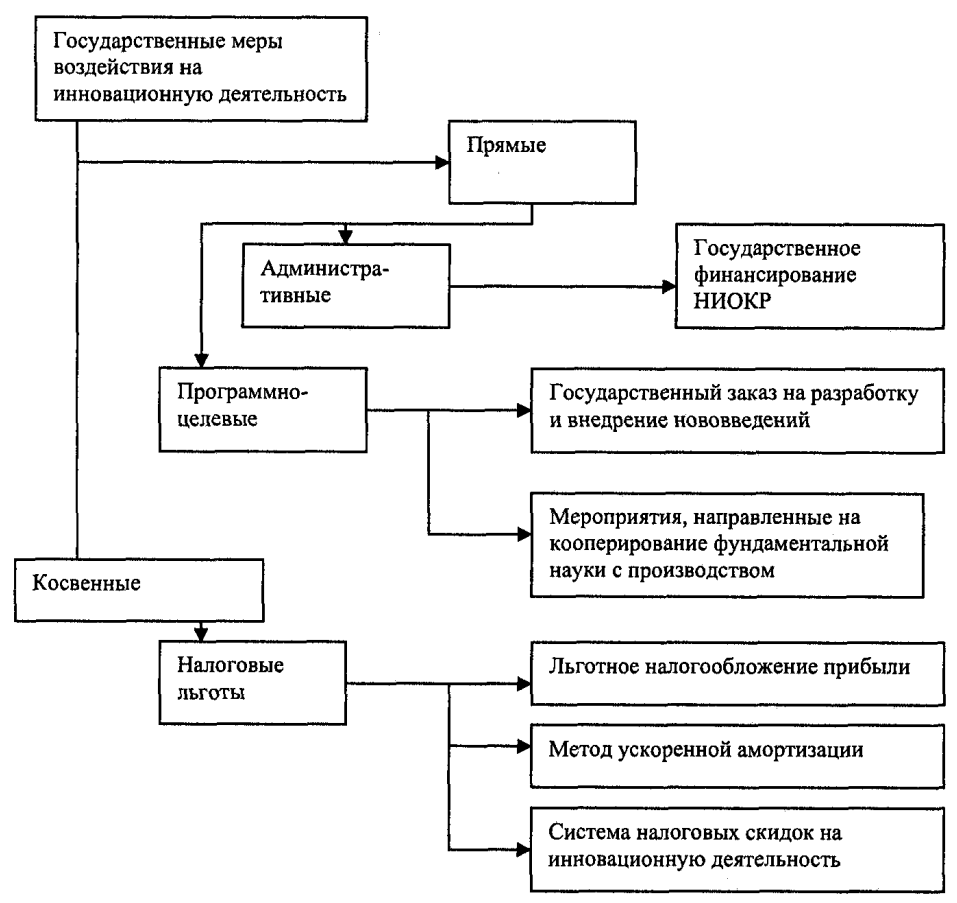

Государственная поддержка инновационной деятельности

Рис. 3.22.Схема господдержки инновационной деятельности

На рис. 3.22. представлена широко известная схема государственного воздействия на инновационную деятельность, в которой нет сегмента разработчиков инноваций из числа индивидуальных и самозанятых предпринимателей. Нет соответствующих мер их прямой и косвенной государственной поддержки. 


\section{Выводы}

1. Более 80\% студентов выпускников ВолгГМУ 2010-2011гг нуждаются в дополнительном образовании по вопросу охраны авторских прав и не менее $50 \%$ студентов выпускного курса заинтересованы в дополнительном знании вопросов интеллектуальной собственности, авторских и смежных прав.

2. Более $70 \%$ студентов не знают номера раздела Гражданского Кодекса, регламентирующего обращение объектов ИС. Это свидетельствует о низкой правовой грамотности студентов в данном вопросе.

3. Большая часть (не мене 75\%) студентов 2011 и 2010 года выпуска ориентированы о необходимости соответствия изобретений общественным интересам, принципам гуманности и морали.

4. Отмечается недостаточно высокий 27-37\% уровень интереса студентов к занятию изобретательской деятельностью на фоне снижение занятий изобретательством среди студентов, посещающих студенческое научное общество.

5. Обнаружено снижение интереса студентов 2009-11гг к включению в образовательные программы ВУЗа вопросов создания и регистрации объектов интеллектуальных прав.

6. Обнаружено превалирование интереса к занятию изобретательством над отсутствием возможностей для 
занятий изобретательством среди студентов 2011 года (интерес на 6,2\% выше возможностей) и среди студентов 2009 года (интерес на 1,8\% выше возможностей).

7. Не менее половины опрошенных в 2009-2011гг студентов отмечают «безусловно или частично» наличие всех возможностей у молодежи для занятий изобретательством.

8. Недостаточный характер материального вознаграждения за изобретательство отметили $46,8 \%$ опрошенных студентов 2009г, 50,3\% в 2010 г и 38\% 2011 года выпуска.

9. В 2011 году среди студентов выпускного курса отмечен максимально высокий показатель мнения «не очень престижного» характера занятий изобретательством. В динамике 2009-11 гг. опроса студентов отмечен достоверный рост мнения не престижности занятия изобретательством (6,5-13,3-16,9\%; p>0,05), по очевидным причинам недостаточной информированности.

10. Не используют предметных знаний о патентованных разработках при подготовке к практическим и семинарским занятиям от 71,3-87,9\% опрошенных студентов, что в $52,3 \%$ случаев, можно объяснить недостаточным умением студентов работать с информацией патентного характера.

11. Необходима разработка и практическая реализация схем государственной поддержки патентных разработок индивидуальных и самозанятых предпринимателей. 


\section{ГЛАВА 4. НОВАЦИОННОЕ ПОВЕДЕНИЕ ВРАЧЕБНЫХ КАДРОВ}

\section{1. ЛИТЕРАТУРНЫЙ ОБЗОР НОВАЦИОННОГО ПОВЕДЕНИЯ ВРАЧЕБНЫХ КАДРОВ}

Врачи выступают носителями медицинских инновационных знаний и культуры их реализации. Для результата лечения важен алгоритм врачебных действий, успех которого определяется культурой инновационного знания и особенностей его реализации. Культура инновационного знания развивается, уточняются определение и область его применения. Недостаточность культуры инновационного поведения нередко превращает заурядные действия в псевдо инновацию. Примером неглубокого знания культуры реализации инновационного знания является действия врачебных кадров СМП Мытищинского муниципального района Московской области в период с 2004 по 2008г в отношении лечения артериальной гипертензии, которая по частоте обращаемости и числу сосудистых осложнений является одной из наиболее важных и нерешенных проблем первичной медико-санитарной помощи данного района. Это подтверждает структура оказываемой СМП помощи, в которой безусловное лидерство принадлежит болезням, сопровождающихся артериальной гипертензией (I.10-I.15 по МКБ Х) от 8357 до 10447 вызовов в год (45,62-57,03 случаев на 1000 населения).Госпитализация таких больных составляет 0,54-2,29\% от числа вызовов или 1,3 случая на 1000 населения.Темпы роста заболеваемости АГ и ассоциированных клинических с АГ состояний за указанный 5 летний период времени опережали естественный прирост населения данного района Московской области. При этом, несмотря на активные повторные выезды СМП, передачу 
активов в амбулаторно-поликлиническое звено, экстренную госпитализацию больных, следование стандартам лечения АГ-число обращений в СМП за указанный период времени не снизилось. По материалам анализа обращает на себя внимание недостаточная культура знания диагностики и лечения АГ врачами СМП и амбулаторно-поликлинического звена, которая в опубликованных материалах объяснена недостаточной культурой знания пациентами необходимости точного и постоянного исполнения врачебных назначений.

Последний вывод базируется на выводахXX съезда российских терапевтов, согласно которым работа СМП Мытищинского муниципального района Московской области по разделу патологии системного АД в достаточно большом (>25\%) проценте случаев замещает функции врачебных кадров амбулаторно-поликлинических учреждений ${ }^{188}$. Улучшение ситуации, как отмечается в опубликованных тезисах, возможно при оптимизации амбулаторно-поликлинической помощи, обучении пациентов в школах по АГ, которых нет во многих районах Московской области.

На самом деле недостаточная эффективность лечения больных ГБ характерна не только для Мытищинского района г.Москвы. В данной публикации обращает на себя внимание отсутствие указаний на внедрение иных, кроме ЭКГ и измерений АД, способов оценки эффективности оказания экстренной неотложной и амбулаторно-поликлинической помощи, контролирующих ишемический характер поражения органов мишеней при скачкообразных изменениях АД. За указанный период времени кроме

${ }^{188}$ Рождественский В.Е., Рождественский М.Е., Пригородова Ю.В./ Артериальная гипертензия как проблема скорой медицинской помощи.// Четвертый национальный конгресс терапевтов (XX Съезд российских терапевтов). Сборник материалов.Москва.,2-4 декабря 2009г.-С.210-211. 
инновационных электрокардиографов «Fukuda»был внедрен в работу СМП препарат нифедипин (синонимы: кардафлекс, коринфар-антагонист кальция1-го поколения). Нередко при оказании неотложной помощи больным с ГБ после парентерального введения препаратов или вместо перорального нифедипина, для предупреждения скачкообразных изменений АД, рекомендуется применение антагониста кальция 3-го поколения- амлодипина, который действует продолжительнее, мягче нифедипина и покрыт оболочкой с контролируемым высвобождением. В стандарте оказания скорой и неотложной помощи больным с АГ указан лишь нифедипин, способствующий скачкообразному снижению АД и рикошетному повышению АД. В стандарте оказания амбулаторно-поликлинической помощи в течение года пациентам с гипертонической болезнью кроме нифедипина таблетированного, покрытого оболочкой с контролируемым высвобождением (частота назначения 0,1), рекомендуется применение амлодипина (частота назначения 0,3) с эквивалентными курсовыми дозами 14600 мг и 2735,5мг,соответственно.

Вопрос недостаточной научной обоснованности стандарта лечения ГБ с применением нифедипина и амлодипина при скоро помощном, стационарном и амбулаторно-поликлиническом оказании медпомощи обнаруживается в материалах 4-го национального конгресса терапевтов России 2009 года. В материалах конгресса в публикации М.П.Рубанова и соавт. ${ }^{189}$ обнаружено увеличение нагрузки на органы мишени повышенным диастолическим артериальным давлением в течение суток у

${ }^{189}$ Рубанов М.П.,Вебер В.Р.,Жмайлова С.В.,Виноградов А.И. /Увеличение нагрузки на органы мишени повышенным диастолическим артериальным давлением в течение суток у больных артериальной гипертензией мужчин при эффективной терапии амлодипином.// Четвертый национальный конгресс терапевтов (ХХ Съезд российских терапевтов). Сборник материалов.Москва.,2-4 декабря 2009г.-С.214. 
пациентов с артериальной гипертензией при эффективной месячной терапии амлодипином (АК-3-го поколения).По данным СМАД было обнаружена отрицательная динамика индекса времени повышенным ДАД-диастолическим артериальным давлением (50\% и более времени) в ночные часы до и после применения амлодипина. Через месяц лечения данным препаратом в 100\% случаев отмечен рост показателя индекса времени повышенного ДАД в течение суток. При этом обращало на себя внимание сравнение с исходными данными до начала антигипертензивной терапии амлодипином рост индекса времени повышенного ДАД днем у 56,2 \% (100-43,8;p<0,05) больных ГБ, ночью -у 43,7\%(100-56,7\%; $<<0,05)^{190,191}$.

В работе А.И. Виноградова и соавт. ${ }^{192}$, проведена оценка влияния амлодипина на суточную вариабельность

${ }^{190}$ Рубанова М.П.,Вебер В.Р.,Жмайлова С.В.,Виноградов А.И. / Увеличение нагрузки на органы мишени повышенным диастолическим артериальным давлением в течение суток у больных артериальной гипертензией мужчин при эффективной терапии амлодипином.// Четвертый национальный конгресс терапевтов (XX Съезд российских терапевтов). Сборник материалов.Москва.,2-4 декабря 2009г.-С.214.

${ }^{191}$ Виноградов А.И., Вебер В.Р.,Рубанова М.П., Сухенко А.И.,,Жмайлова С.В.Динамика вариабельности АД в течение суток у больных артериальной гипертензией с нормальным психоэмоциональным фоном и субклинической депрессией на фоне эффективной терапии амлодипином. // Тезисы научного конгресса «Артериальная гипертония:от А.Л.Мясникова до наших дней» под ред. акад Е.И.Чазова, В.И.Скворцовой.Март 2012.с.44.

${ }_{192}$ Рубанова М.П., Жмайлова С.В., Сухенко А.И., Виноградовав А.И., Антонов Е.К. /Особенности показателей нагрузки повышенным и пониженным артериальным давлением у больных артериальной гипертензией женщин с нормальным психоэмоциональным фоном и субклинической депрессией до лечения и через месяц эффективной терапии амлодипином. // Тезисы научного конгресса «Артериальная гипертония:от А.Л.Мясникова до наших дней» под ред. акад .И.Чазова и В.И.Скворцовой.Март 2012.c.32. 
АД у больных АГ женщин с различным психоэмоциональным фоном (ПЭФ). Авторами также выявлено повышение суточной вариабельности АД при приеме препарата. Как указывают авторы, подход к назначению амлодипина больным АГ должен быть дифференцированным как у больных с субклинической депрессией, увеличивающей вариабельность САД и ДАД ночью, так и у больных с нормальным психоэмоциональным фоном.У последних вариабельность АД, особенно ДАД ночью, становится избыточно высокой и впервые регистрируется под влиянием препарата.

Таким образом, по имеющимся публикациям у больных ГБ женщин и мужчин с изменённым и нормальным психоэмоциональным фоном (ПЭФ) применение монотерапии препаратом амлодипин из перечня стандартов лечения ГБ в амбулаторно-поликлинических условия ${ }^{193}$ и в специализированном стационаре не обеспечивает среднесрочной цели лечения-снижения суточной вариабельности АД и органопротекции. У больных АГ с вариабельным ДАД его перепады под влияем лечения амлодипином и нифедипином требуют безупречной работы механизмов регуляции органного кровотока органов мишеней, что возможно лишь у больных ГБ без морфологических изменений в коронарных артерия ${ }^{194}$. С другой стороны использование в качестве альтернативы бета-адреноблокатора

${ }^{193}$ Проекты стандартов медпомощи. Официальный сайт Российского медицинского общества по АГ (РМОАГ).[Электронный ресурс].-Режим доступа http://www.gipertonik.ru/standards. Дата обращения 16.03.13.

${ }^{194}$ Рубанова М.П., Вебер Р.В., Жмайлова С.В., Виноградов А.И. / Избыточная вариабельность артериального давления как предикт развития функциональной коронарной недостаточности у больных артериальной гипертензией.// Четвертый национальный конгресс терапевтов (XX Съезд российских терапевтов). Сборник материалов.Москва.,2-4 декабря 2009г.-С.213-214. 
метопролола у больных АГ с субклинической депрессией обнаружило нарастание нагрузки пониженным АД на органы мишени ночью на фоне терапии метопролола тартратом $^{195}$, который также указан в перечне препаратов стандарта амбулаторно-поликлинического годового лечения больных гипертонической болезнью (частота назначения $0,3)$, оптимальной суточной дозой 100 мг и эквивалентной курсовой дозой 36500 мг.

Приведённые данные указывают на небезопасность монотерапии ГБ рекомендованными группами препаратов по разработанным стандартам. В тоже время в литературе опубликованы убедительные данные взаимосвязи вариабельности показателей АД с показателями кислородного режима тканей, высоко коррелирующими с показателями ремоделинга миокарда ${ }^{196}$ и преимуществами реремоделинга бисопролола в сравнении с метопрололом у больных ХОБЛ с ИБС. При этом показано, что нарушение тканевого обмена кислорода (повышение интенсивности тканевого потребления и снижение скорости постишемического восстановления кислорода в дерме) является основанием для активного поиска поражения почек, ремоделирования сердца у больных ХСН с ХОБЛ и показанием для отмены метопролола и назначения бисопролола. Упомянутый диагностический способ оценки нарушений тканевого обмена кислорода в дерме может использоваться как

${ }^{195}$ Жмайлова С.В., Вебер Р.В., Рубанова М.П.,Виноградов А.И., Губская М.П., Кулин Н.А./Изменение показателей нагрузки повышенным и пониженным АД у больных артериальной гипертензией женщин с нормальным психоэмоциональным фоном и субклинической депрессией на фоне терапии метопрололом. // Тезисы научного конгресса «Артериальная гипертония:от А.Л.Мясникова до наших дней» под ред. акад Е.И.Чазова и член-корр. В.И.Скворцовой. Март 2012.c. 24 .

${ }^{196}$ Иванова Д.А. Кардиоренальные соотношения в диагностике и лечении хронической сердечной недостаточности у больных ХОБЛ. Автореф дис..канд.мед. наук. Волгоград.2011.23с. 
для определения ремоделирующих изменений органов мишеней ${ }^{197}$ почек и сердца у больных ХСН с ХОБЛ, так и для определения оптимального уровня индивидуального артериального давления (патент RUNo2103908.Дата публикации 10.02.98. А.Ф.Апухтин).Указанный способ не имеет широкого коммерческого применения по причинам отсутствия разработанных прямых и косвенных мер господдержки инноваций. Клиническо-диагностические достоинства способа у больных АГ при монотерапии антагонистом кальция или/и капотеном ${ }^{198}$, сохраняют свою актуальность в структуре последних национальных клинических рекомендаций «Диагностика и лечение артериальной гипертонии» Российского медицинского общества по артериальной гипертонии ${ }^{199}$. Разработанные автором с соавт. два способа 200,201 актуальны для диагностики

${ }^{197}$ Стаценко М.Е.,Иванова Д.А.,Апухтин А.Ф. Взаимосвязь показателей тканевого обмена кислорода и функции почек у больных хронической сердечной недостаточностью с сопутствующей хронической обструктивной болезнью легких. Сборник материалов III Национального конгресса терапевтов. 5-7 ноября 2008г.Москва. -2008.-C.100.

${ }^{198}$ Апухтин А.Ф.. Состояние периферического кровообращения и тканевого обмена кислорода у больных гипертонической болезнью в зависимости от антигипертензивной терапии. Автореф. дисс.. канд.мед.наук. Волгоград.,2004.,23с

${ }^{199}$ Клинические рекомендации. Диагностика и лечение артериальной гипертонии./Системные Гипертензии. 2019;16(1): DOI:10.26 442./2075082Х.2019.1.190179. Чазова И,Е.,Жернакова Ю.В. от имени экспертов.

${ }^{200}$ Апухтин А.Ф. «Способ диагностики нарушения периферического кровообращения» патент RU №2054175.Официальный бюллетень комитета Российского агентства по патентам и товарным знакам «Изобретения». - Москва.-1996.-№4.С.231.

201 «Способ диагностики нарушения эндотелийзависимой регуляции локального кровотока» патент RU №2340278.Дата публикации 10.04.07. Апухтин А.Ф., Стаценко М.Е.) 
маскированной АГ и безопасного достижения целевых цифр АД при различных схемах медикаментозного лечения больных АГ с коморбидной патологией. В частности, по п.3.6.9. раздела клинических рекомендаций «Артериальная гипертония у больных с атеросклерозом» 2019г у больных с периферическим атеросклерозом рекомендуется рассмотреть назначение бета-адреноблокаторов (БАБ). Применение последних, по мнению национальных экспертов, не сопровождается при АГ обострением симптомов поражения периферических артерий. Цитируемые авторские способы диагностики могут существенно оптимизировать определение для больных АГ безопасных при периферическом атеросклерозе доз БАБ. В 2019 году автор подал заявку на научно-образовательный грант Российского общества кардиологов Scardio по проекту «Оптимизация маршрутизации и раннего выявления периферического атеросклероза сосудов нижних конечностей» (справка в приложении).

Выводы врачей СМП Мытищинского муниципального района Московской области оказывающих экстренную медпомощь СМП больным АГ обусловлены «добросовестным заблуждением» в процессе «инновационного» освоения нифедипина на основе существующих стандартов оказания медпомощи больным АГ. Результаты «манометрически эффективного» антигипертензивного амбулаторно-поликлинического применения амлодипина и метопролола в г.Новгороде у больных АГ с различным психо-эмоциональным фоном (ПЭФ) опубликованные в 2009г и 2012г, демонстрируют неэффективность рутинного применения лечебного стандарта амбулаторно-поликлинического лечения больных ГБ препаратами амлодипин и метопролол.

Дорогостоящие суточные мониторы АД, рекомендуемые по стандартам оказания помощи для оценки эффективности коррекции и суточной вариабельности 
АД у больных с АГ, малодоступны и дефицитны в ЛПУ. Неслучайно частота предоставления суточного мониторирования АД в амбулаторно-поликлинических условиях и в специализированном отделении по стандарту лечения составляет 0,5 на одного госпитализированного пациента, что подчеркивает дефицитность данного вида исследования. Получение информации о состоянии миокарда и клапанного аппарата методом эхокардиографии также ограничено в амбулаторно-поликлинических условиях частотой предоставления 0,5 на 1 амбулаторно пролеченного больного. В специализированном стационаре 14 дневного лечения ГБ частота предоставления Эхо-КГ ещё ниже-0,01 (приложение). Не менее дефицитны по стандартам лечения ГБ и некоторые другие виды инструментального исследования, в том числе суточное мониторирование ЭКГ.

Утвержденные федеральным органом исполнительной власти в сфере здравоохранения стандарты медицинской помощи предназначены для конкретизации и одновременно для ограничения объемов медицинской помощи, оказываемой населению в рамках государственных гарантий. Вместе с тем, в утвержденных стандартах не всегда указаны лекарственные формы применения медикаментов, коды, торговые наименования материалов и изделий медицинского назначения, что не позволяет уточнить тот или иной элемент медицинской помощи, практически осуществить проверку соответствия оказанной медицинской помощи стандарту, в том числе в части обоснованности назначения лекарств и выполнения методов исследований. Частота 0.5 предоставления СМАД для определения оптимального уровня артериального давления в амбулаторно-поликлинических условиях при подборе комбинированной гипотензивной терапии явно ограничивает возможности эффективного лечения больных ГБ. Вместе с тем в российской литературе с 1998 года доступен способ определения оптимального уровня 
индивидуального артериального давления ${ }^{202}$, не уступающий объективности СМАД. По данным анализа литературы складывается впечатление отсутствия для врачебно-медицинских инноваций не только необходимых законодательных условий, инвестиций, преференций, ресурсного обеспечения в стандартах оказания медицинской помощи,но и законодательно-оформленной основы новационной эффективности действий врачей, которые бы целенаправленно управлялись и поддерживались федеральными и муниципально-государственными органами власти. Для оценки участия муниципально-государственных органов власти в формировании информационно-эффективной основы новационного поведения врачей проведено анкетирование практических врачей города Волгограда.

${ }^{202}$ Патент на изобретение RU №2103908. Дата публикации 10.02.98. автор А.Ф.Апухтин. 


\section{2.Новационное поведение врачебных кадров (результаты собственного исследования)}

Проведено анкетно-анонимное исследование 452 работающих врачей г.Волгограда (сплошные гнездовые выборки) проведено в мае-сентябре 2009-2010 года с помощью предварительно разработанных 23 вопросов.Все участники выражали добровольное информированное согласие на участие в исследовании.

K числу факторов оказывающих непосредственное влияние на интеллектуально-профессиональную деятельность относится стаж работы. В соответствии с существующим положением по вопросу аттестации врачей, провизоров и других специалистов с высшим образованием в системе здравоохранения высшая врачебная квалификационная категория не присваивается врачам имеющим стаж работы по аттестуемой специальности менее 10 лет $^{203}$. Согласно этого положения врачам имеющим степень доктора медицинских наук (д.м.н.) высшая врачебная квалификационная категория присваивается заочно по представлению руководителя учреждения, в котором работает д.м.н. Учитывая влияние на присвоение высшей квалификационной категории факторов производственного стажа и ученой степени, результаты полученных ответов оценивались с учетом производственного и научно-квалификационного факторов.

Среди опрошенных 452 врачей стаж работы до 10 лет указали 285 (63\%) и стаж 10 и более лет отметили 167(37\%) человек. 41 врач (9\%) имел ученую степень кандидата медицинских наук. 30 (73,2\%) кандидатов медицинских наук имели стаж до 10 лет и $11(26,8 \%)$ указали стаж работы 10 и более лет. Пять специалистов имели степень доктора медицинских наук. Один со стажем до 10 лет, остальные четыре со стажем 10 и более лет (рис.4.1).

${ }^{203}$ Приказ М3 №33 от 16.02.95. 


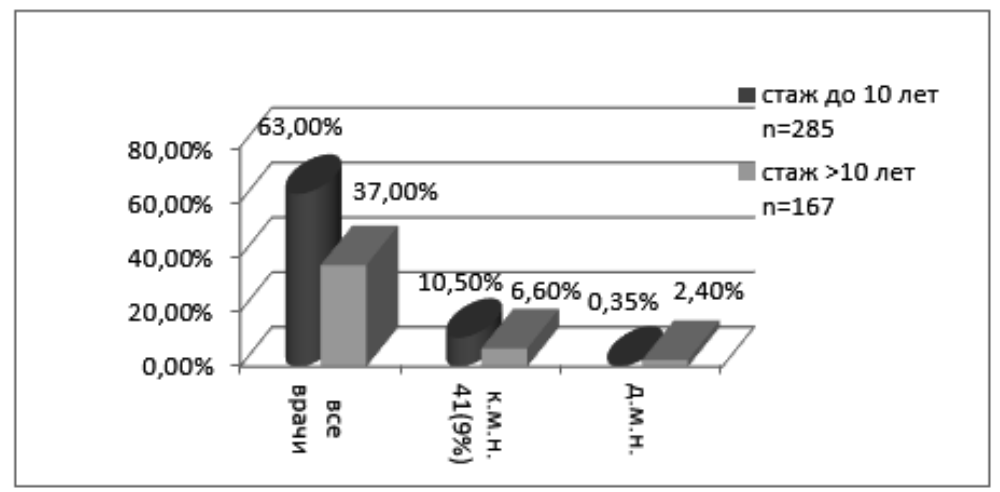

Рис 4.1.Структура квалификационного стажа и учёной степени

Технико-аппаратную оснащенность больниц, станций СМП и поликлиник города 82,5\% всех врачей-специалистов оценили как не совсем недостаточную, 73,9\% как недостаточную,лишь 13,7\% врачей считали оснащенность хорошей (рис.4.2)

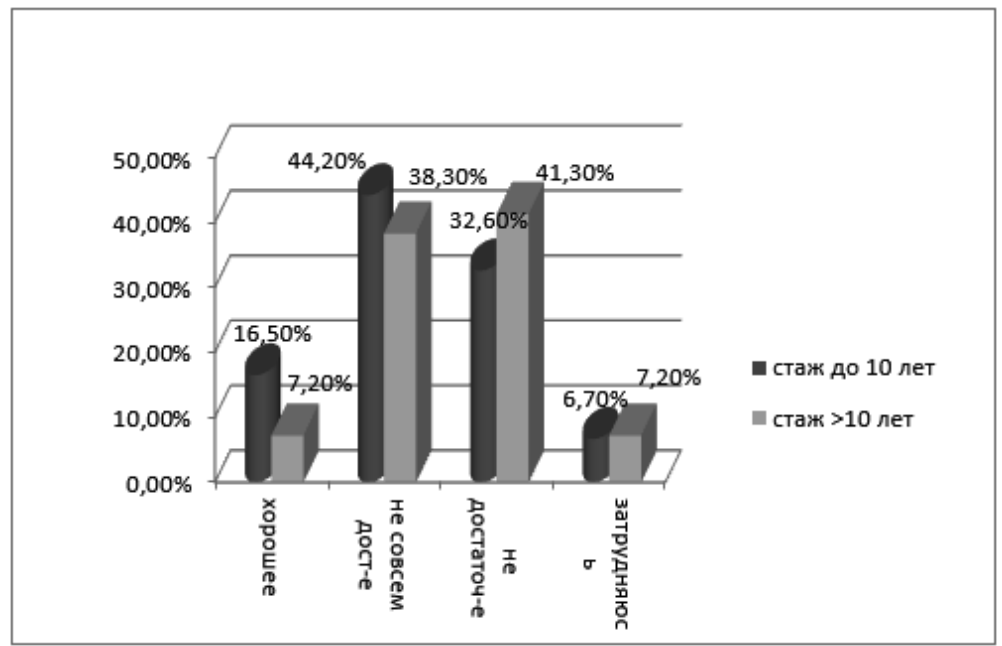

Рис 4.2.Состояние аппаратной оснащенности ЛПУ 
$31,2 \%$ врачей со стажем до 10 лет и 29,9\% со стажем свыше 10 лет отметили, что практически используется исключительно и преимущественно импортная аппаратура. Лишь 18,9 \% врачей со стажем до 10 лет и 36,5\% со стажем свыше 10 лет респондентов считали, что импортная и отечественная аппаратура используются в одинаковой мере. (Рис.4.3.)Менее четверти врачей, независимо от врачебного стажа (24,9-22,7\%), отметили использование преимущественно отечественной аппаратуры.

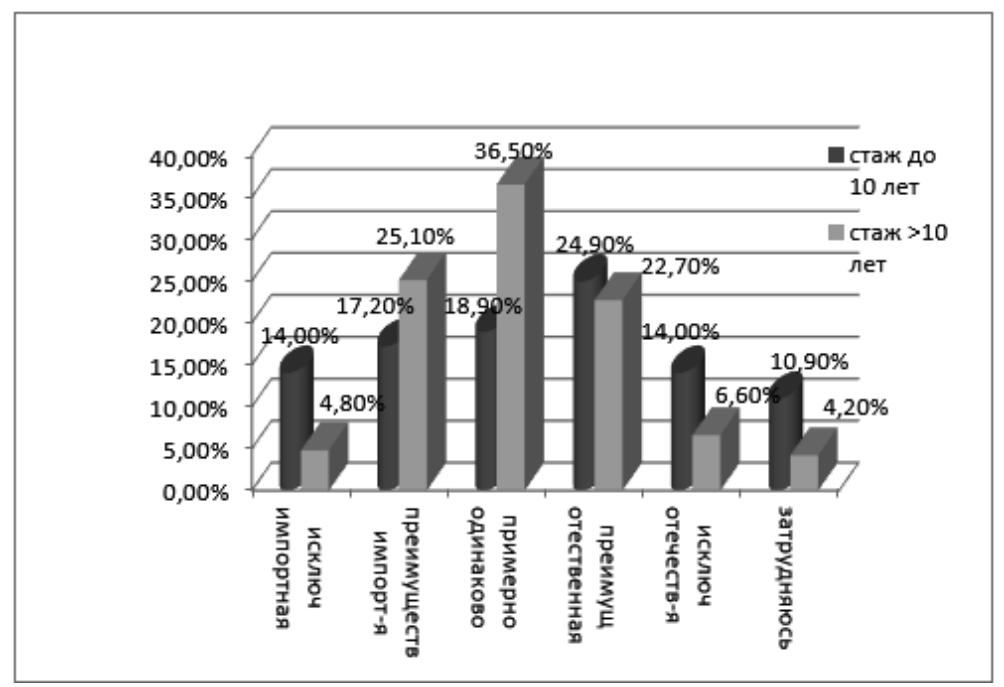

4.3.Структура замещения лечебно-диагностического оборудования аппаратами импортного и российского производства

На взгляд $42,5 \%$ опрошенных специалистов сложилась устойчивая зависимость отечественной медицины от импортной аппаратуры. Отрицали данную зависимость около $12 \%$ врачей, несколько чаще более опытные врачи со стажем превышающим 10 лет (рис 4.4.). 


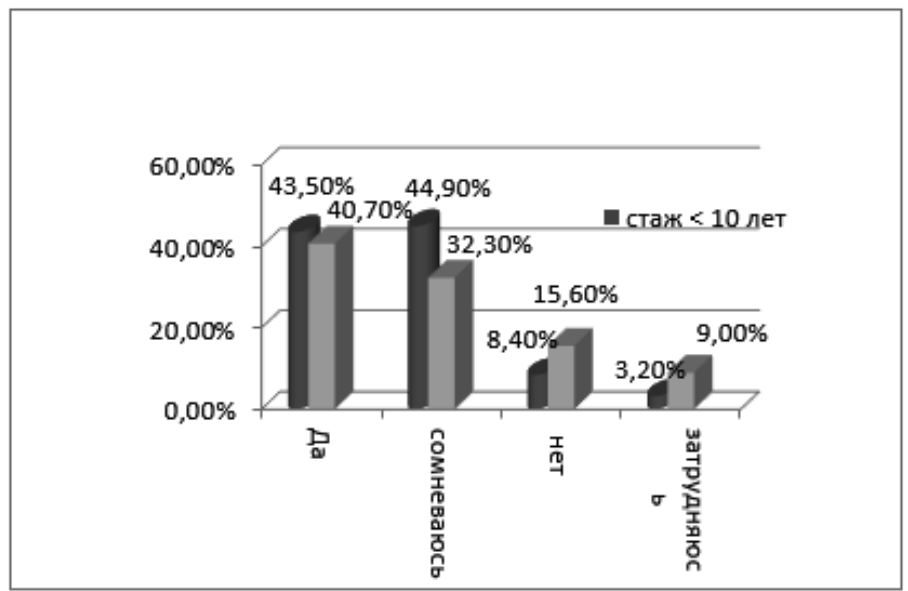

Рис 4.4.Наличие зависимости медицины от импортного оборудования.

84,2 \% опрошенных врачей независимо от стажа отметило наличие угрозы зависимости медицины от импортного оборудования. При этом 32,3\% врачей со стажем $>10$ лет и 44,9\% до 10 лет выразили сомнение(вместе 77,7\%), ещё около $1 \frac{1}{4}$ (18,2-26,3\%) отрицали её. (Рис. 4.5.).

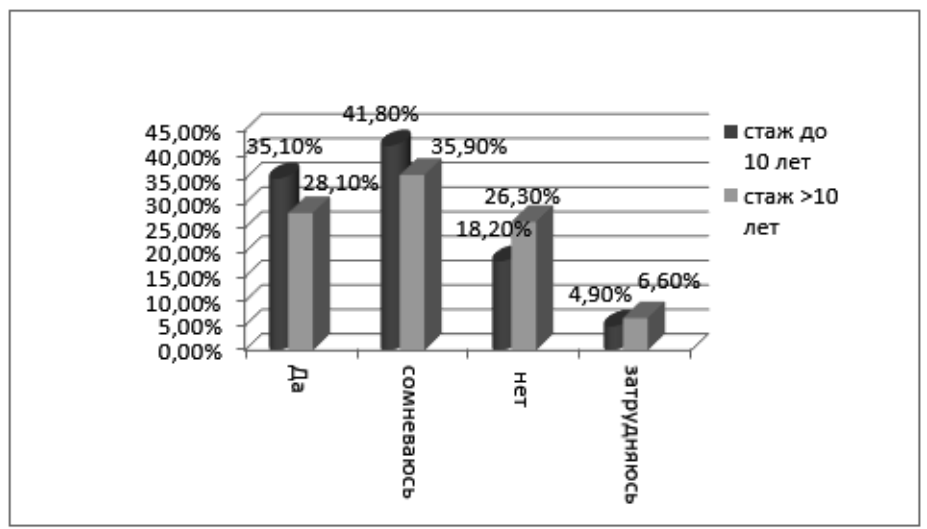

Рис 4.5.Существование угрозы зависимости медицины от импортного оборудования 
Аналогичное мнение угрожающей зависимости отечественной медицины от импортного оборудования выявлено «ЗАО Стратегия Центр»,в результате макроэкономических изысканий «Анализ тенденций и прогноз основных макроэкономических показателей характеризующих уровень социально-экономического развития Российской федерации в 2009-2030 годы, опубликованного31 января 2009г. В экспертной оценке значений макроэкономических показателей на постпрогнозный период до 2045 года подчеркивается практическое отсутствие конкурентоспособной продукции микроэлектронной промышленности, телекоммуникационного оборудования и средств вычислительной техники, в результате чего зависимость российской информационной инфраструктуры от поставок зарубежных информационно-коммуникационных технологий значительно превышает критический уровень.

Определяя место России в современной мировой экономике в начале 2014 года президент РФ подтвердил критически высокий уровень поставок зарубежных технологий. За прошедшие два десятилетия, по мнению В.В. Путина ${ }^{204}$ Россия«....фактически пережила масштабную деиндустриализацию, потерю качества и тотальное упрощение структуры производства. Отсюда крайне высокая зависимость от импорта технологий и сложной продукции».

Вероятно, из-за критически низкого уровня реализации в России российских технологий, актуальна разработка и практическое внедрение российских инновационных лечебно-диагностических технологий (в том числе различной аппаратуры) отмеченное $61,5 \%$ респондентов. Причём данного мнения достоверно чаще

${ }^{204}$ В.В.Путин «О наших экономических задачах» 2012. 
придерживались более опытные врачи со стажем от 10 лет работы (71,9\% и 55,1\% p<0,001;Рис. 4.6). Лишь 6-7 \% отрицали и затруднялись высказать своё мнение по данному вопросу.

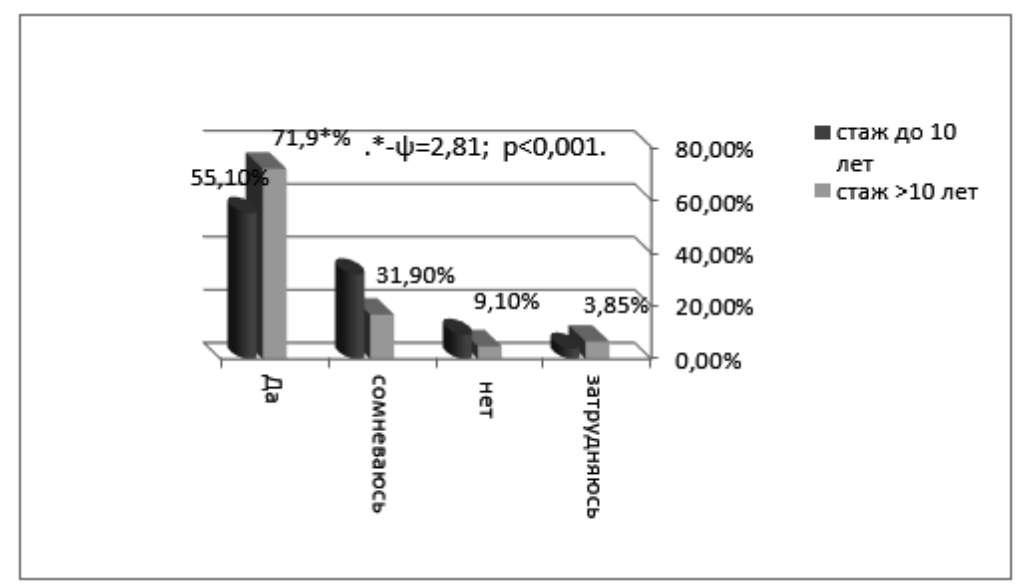

Рис 4.6.Актуальность разработок и внедрений российских медицинских технологий

Все 137(30,3\%) врачей занятых изобретательством знали о современных российских патентованных разработках по кардиологии и эндокринологии. Остальные 315 (69,7\%) врачей-специалистов никогда не занимались изобретательством. Из них 250 (166 врачей стаж до 10 лет и 84 врача стаж 10 лет и более) ничего не знали о современных российских патентованных разработках по специальности и 65 (40 врачей стаж до 10 лет и 25 врачей стаж 10 и более лет)затруднялись дать ответ на данный вопрос. При этом врачи со стажем до 10 лет достоверно чаще $(\mathrm{p}<0,01)$ не знали о современных российских патентованных разработках и реже занимались изобретательством (Рис. 4.7). 


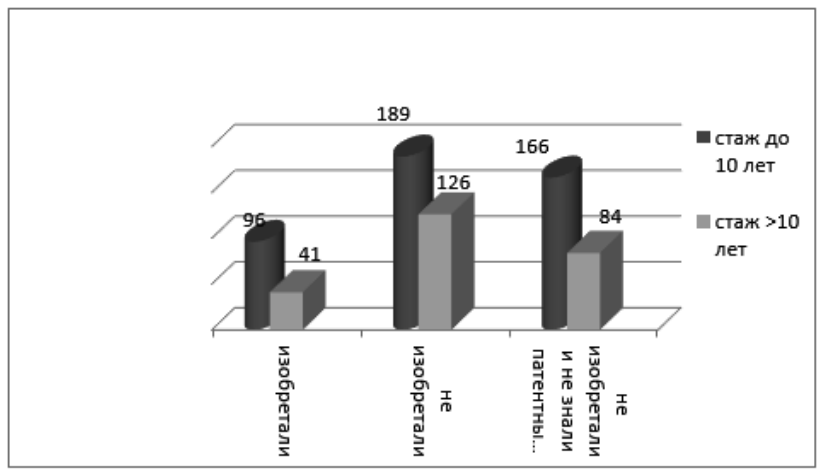

Рис.4.7.Занятие изобретательством и знание сторонних разработок врачами с различным производственным стажем

Использовали в работе отечественные патентованные разработки(вопрос анкеты №8) 109 (24,1\%) врачей - специалистов (71 стаж до 10 лет и 38 стаж более 10 лет). Большая часть 75,88\% (343чел; 279 отрицательно ответивших и 64 затруднившихся дать ответ) интервьюированных специалистов не использовало их в своей работе ( 214 стаж работы до 10 лет и у 129 стаж >10 лет $\Psi=4,49 ; \mathrm{p}<0,001)$. Таким образом, в структуре врачебных кадров не использовавших патентных разработок в своей работе преобладали врачи с производственным стажем до 10 лет. Процент использовавших патентные разработки не различался в группах врачей с различным производственным стажем (рис.4.8).
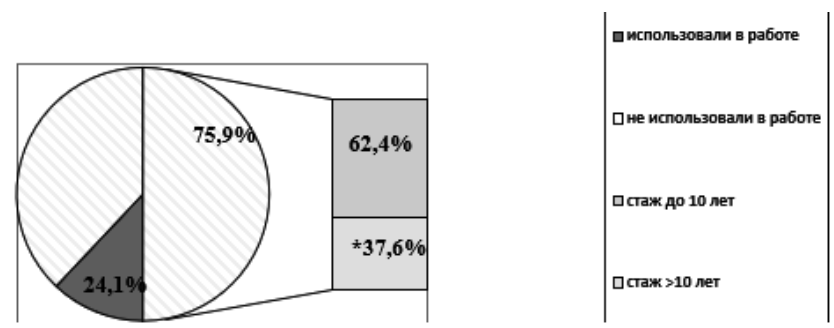

Рис. 4.8. Влияние производственного стажа на частоту применения патентных раработок; $* \Psi=4,49 ; p<0,001$; 
Из 137 (30,3\%) занимавшихся изобретательством респондентов 45 (9,95\%) почти сразу оставили занятие изобретательством. 39 (28,46\%) респондентов разрабатывали и внедряли свои изобретения. Из них 29 с производственным стажем до 10 лет и 10 врачей со стажем 10 лет и более (рис 4.9.).

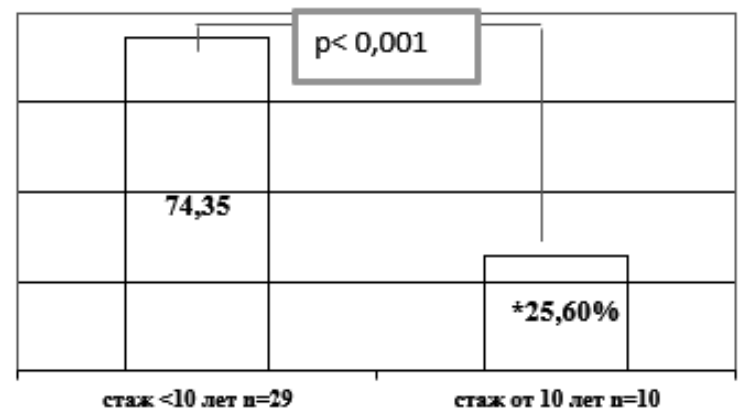

Рис. 4.9. Показатели изобретательской активности врачей с различным стажем работы. ${ }^{* *-}-\Psi=4,12 ; p<0,001$

Выявлена статистически достоверная более высокая изобретательская активность в группе врачей с производственным стажем до 10 лет. Разрабатывали, но не стали внедрять свои разработки 19 врачей, из них 17(63,1\%) со стажем до 10 лет и $2(18,1 \%)$ с производственным стажем $>10$ лет (рис.4.10).

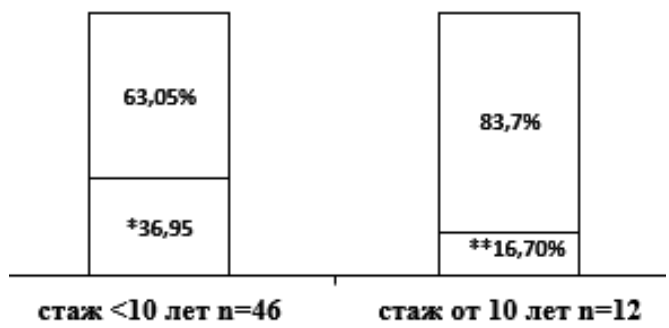

Рис.4.10.Частота внедрений врачебных разработок в зависимости от стажа работы. ${ }^{* *}-\Psi=4,12 ; p<0,001 ; *{ }^{*}-\Psi=1,67 ; p<0,05$ 
При сравнительном качественном анализе респондентов разрабатывавших и внедрявших свои изобретения (39чел) по отношению к не внедрявшим свои изобретения (19чел) в группе более опытных врачей выявлено статистически достоверно меньше случаев,не внедренных патентных разработок.

Пытались, но не смогли внедрить свои изобретения 34 врача-специалиста. Из них 22 человека с производственным стажем работы до 10 лет и 12 врачей со стажем работы от10 лет. При сравнительном качественном анализе 2-х групп респондентов, не внедривших свои изобретения (19чел) и не ставших внедрять изобретения (34чел) выявлено статистически достоверно больше врачей со стажем работы от 10 лет не внедривших изобретения, в сравнении с не ставшими внедрять изобретения ( $\left.\psi^{*}=7,12 ; \mathrm{p}<0,001\right)$. В тоже время, не обнаружено аналогичного различия у врачей со стажем работы до 10 лет $\left(\psi^{*}=1,25 ; \mathrm{p}<0,2\right)$.

Таким образом, количество врачей со стажем работы от 10 лет пытавшихся внедрить свои изобретения, статистически достоверно больше не пытавшихся внедрять изобретения. Данный факт свидетельствует о статистически достоверно большей внедренческой активности врачей со стажем работы от 10 лет, в сравнении с группой менее опытных врачей. Последние, хотя и демонстрировали более высокую изобретательскую активность, однако чаще не предпринимали попыток внедрений и соответственно реже внедряли патентные разработки.

На вопрос существования сложностей разработки и внедрения инновационной лечебно-диагностической технологии (в том числе аппаратуры) 43 (9,5\%) специалиста отметили преимущественно сложности разработки, 190(42\%) отметили примерно одинаковую сложность как разработки так и внедрения инновационных технологий, 170 (37,6\%) отметили более высокую сложность практического внедрения инновационных технологий. 
По мнению большинства опрошенных основные трудности, которые встают перед изобретателями это: отсутствие материальной заинтересованности авторов придумывать что-то новое 218(48,2\%; до 10 лет 144 чел., и 74 чел. от 10 лет; $\left.\psi^{*}=4,56 ; \mathrm{p}<0,001\right)$, отсутствие материальной заинтересованности авторов внедрять свои изобретения (46,9\%; до 10 лет 127 чел., и 85 чел. от 10 лет; $\left.\psi^{*}=2,86 ; \mathrm{p}<0,001\right)$, недостаточная поддержка изобретателей со стороны государственных и/или муниципальных органов власти $(28,8 \%$; до 10 лет 78 чел., и 52 чел. от 10 лет; $\left.\psi^{*}=2,25 ; \mathrm{p}<0,02\right)$, несовершенство законодательной базы в области изобретательства (27,8\%; до 10 лет 84 чел., и 42 чел. от 10 лет; $\left.\psi^{*}=3,60 ; p<0,001\right)$, отсутствие специальных структур которые бы индивидуально работали с изобретателями (13,9\%; до 10 лет 55 чел., и 18 чел. от 10 лет; $\psi^{*}=3,91 ; \mathrm{p}<0,001 ;$ Рис.4.11).

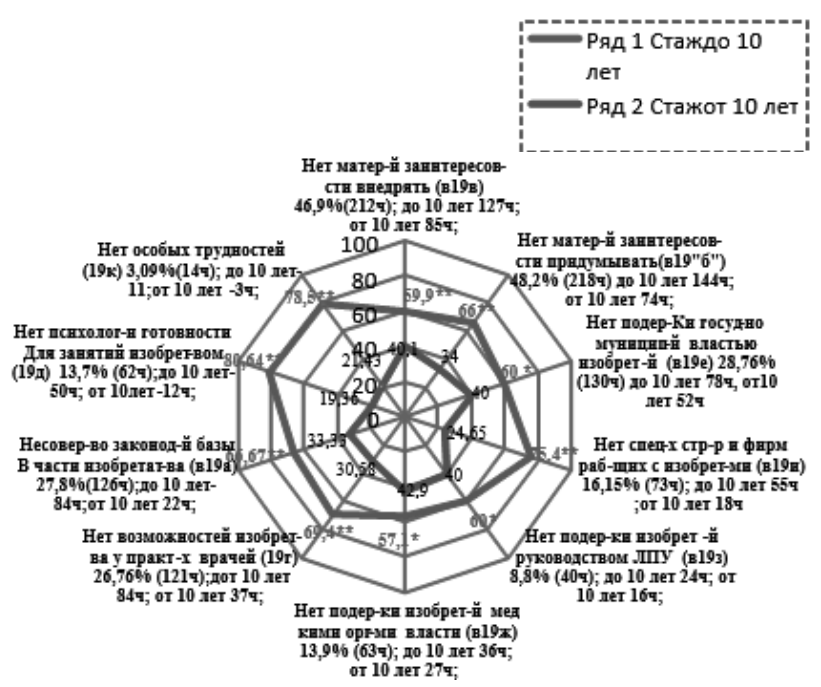

Рисунок 4.11. Структура наиболее значимых трудностей для занятий изобретательством в зависимости от профессионального врачебного стажа. Достоверность различия -точечный критерий Фишера: $\psi^{*}$ $p<0,03 ; \psi^{* * *}-p<0,001$ 
Лишь 3,1\% считали, что нет особых трудностей перед изобретателями (со стажем до 10 лет 11 чел., со стажем от 10 лет -3 чел; $\left.\psi^{*}=1,87 ; \mathrm{p}<0,03\right)$.

На вопрос анкеты способствует ли ПНП «Здоровье» разработке и внедрению отечественных изобретений в медицину положительно ответили $(\mathrm{n}=68) 15,07 \%$, отрицательно (n=221) 25,72\% врачей. Сомнение высказали $(\mathrm{n}=226)$ 49,0\%, затруднились ответить (n=46) 10,2\% интервьюированных докторов. 


\section{Обсуждение}

С 1 января 2006 года стартовал национальный приоритетный проект «Здоровье».Основная задача проекта - улучшение ситуации в здравоохранении и создание условий для его последующей модернизации.В рамках реализации проекта «Здоровье» выделены три основных направления: повышение приоритетности первичной медико-санитарной помощи, усиление профилактической направленности здравоохранения, расширение доступности высокотехнологичной медицинской помощи.То есть ПНП «Здоровье»не ставил своей целью способствование разработке и внедрению отечественных патентных изобретений в медицину. Видимо не случайно на вопрос способствования ПНП «Здоровье» разработке и внедрению в медицину российских изобретений подавляющее большинство $(84,9 \%)$ врачей (сумма сомнительных-49,0\%, затруднительных-10,2\%,отрицательных ответов -25,7\%) не отметили положительного влияния ПНП. Лишь 15,1\% (n=68) отметили «способствование».

Несмотря на статистически достоверно более высокую изобретательскую активность молодых врачей со стажем работы до 10 лет, попытки и успехи внедрений изобретений более показательны у врачей с производственным стажем от 10 лет и выше. Так врачи с производственным стажем от 10 лет работы статистически достоверно реже: а)отказываются от попыток внедрений своих изобретений; б)отмечают отсутствие особых трудностей, которые встают перед изобретателями.

69,7\% (315) врачей-специалистов никогда не занимались изобретательством. Вероятно, по причине незнания существующего уровня техники, необходимого для изобретательства, врачи не занятые изобретениями не знают о современных российских и зарубежных патентованных 
разработках в области кардиологии и эндокринологии. И это в век интернета. Тенденции использования Рунета врачами по данным исследования MEDI-Q205 последние годы не менее впечатляет, чем в целом среди населения России. Однако в контексте профессиональной врачебной деятельности интернет представляет различную ценность: наиболее высоко он оценивается гастроэнтерологами, урологами и неврологами. Менее высоко оценивают интернет терапевты и кардиологи. Гораздо ниже ценят важность интернета эндокринологи, пульмонологи, психиатры.

По литературным данным наиболее интенсивно используют интернет врачи моложе 31 года. По нашим данным, напротив, врачи со стажем до 10 лет чаще (различие статистически высоко достоверно $\left.\psi^{*}=4,93 ; p<0,001\right)$ не знают о современных российских патентованных разработках, хотя пользуются интернетом без сомнений чаще. При этом достоверно реже занимаются изобретательством в сравнении с более опытными врачами.

Возможным объяснением недостаточной информированности молодых врачей кардиологов, эндокринологов и терапевтов в области современных патентованных разработок является, с одной стороны, недостаточно активная нацеленность на профессиональные интернет-ресурсы в качестве источников инновационной информации. С другой стороны, сложившийся стереотип интернет предпочтений, преимущественно поверхностно-обзорного характера среди врачей широкого профиля. Так по данным выше цитированного исследования MEDI-Q для дерматологов, урологов, неврологов наиболее важны статьи с данными клинических исследований. Для кардиологов и гастроэнтерологов наибольшую значимость

${ }^{205}$ Е.Н.Молокова.Врачи как аудитория интернет пользователей: профиль, потребности, предпочтения. Ж.Менеджер здравоохранения.2011.№1.с.43-51. 
имели обзорно-научные статьи. Терапевты же отдавали предпочтение новостям медицины.

Информационная значимость обзорных научных статей и новостей медицины как источника информации по отечественным патентованным медицинским технологиям невелика, из-за скромного присутствия и низкого рейтинга российских публикаций медицинской тематики в международных базах данных ${ }^{206}$. Так согласно данным рейтинга научных организаций здравоохранения, опубликованным в отчете $\operatorname{SIR}^{207}$ за 2010год, Российская академия медицинских наук занимает 658-е место, а мало кому известный в России университетский госпиталь Cleveland (США) 358-е место.

По данным настоящего опроса чужие патентованные разработки врачами использовались нечасто (23\% свыше 10лет и 25\% до 10лет работы; р>0,05)вероятно, вследствие невысокого рейтинга публикаций зарубежной медицинской тематики в российских медицинских изданиях. В тоже время ещё 8,6\% (39) врачей пытались внедрять свои разработки. Внедренческая активность инноваций среди врачей занимающихся изобретательством составила 33\%, что не очень результативно. Результативность показателя в контексте данных Роспатента ${ }^{208}$ об изобретательской активности населения по числу поданных заявок на выдачу патентов на изобретения снизилась по Волгоградской области вдвое в 2014 году против 2006 года (таб.4.1)

${ }^{206}$ В.И.Стародубов, Н.Г.Кулакова,Л.А.Цветкова,В.А.Маркусова.Российская медицинская наука в зеркале международного и отечественного цитирования.Ж.Менеджерздравоохранения.2011.№1.-С.6-20.

${ }^{207}$ Ranking of research Institution SIR World Report 2010 Health Sciences /SCImago/(2007)/SJR-SCImago Journal \&Country Rank. RetrievedDecember 12.2010.fromhtpp://www.scimagojr.com

${ }^{208}$ Анализ изобретательской активности в регионах PФ. URL peсурс: http://www.fips.ru/sitedocs/a_iz_akt_2015.pdf 
Таблица 4.1. Количество поданных российскими заявителями заявок на выдачу патента на изобретение в 2006-2015 гг. в регионах Южного и Северо-Кавказского федеральных округов.

$$
\begin{array}{llllllllll}
2006 & 07 & 08 & 09 & 10 & 11 & 12 & 13 & 14 & 2015
\end{array}
$$

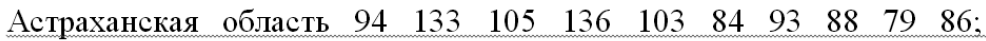
Волгоградская область 454512387406358279277268263288 ; Краснодарский край $596 \quad 552598443536485513478492476$; Республика Адыгея $\quad \begin{array}{llllllllll} & 3 & 5 & 5 & 20 & 6 & 5 & 4 & 5 & 9\end{array}$ $\begin{array}{lllllllllll}\text { Республика Калмыкия } & 3 & 1 & 2 & 2 & - & 3 & 5 & 12 & 34 & 45 \text {; }\end{array}$ Ростовская область $678601725 \quad 758658 \quad 628693 \quad 764 \quad 689748$.

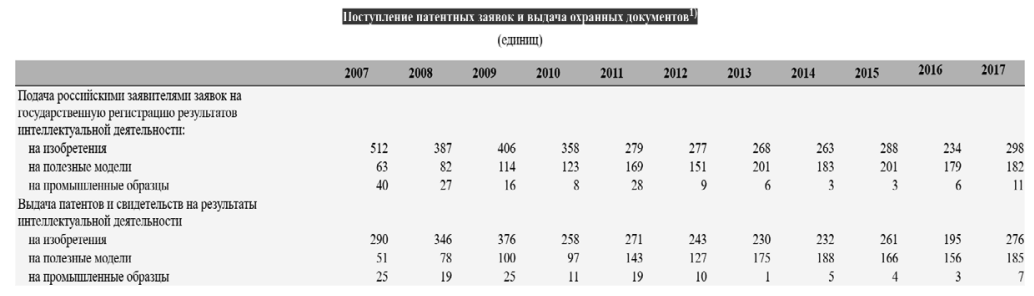

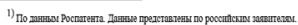

Как видно из представленных на сайте https:// volgastat.gks.ru/209 данных снижение показателей патентной активности за период 2007-17гг. в Волгоградской области отмечается с 2007 года, когда показатель заявок по изобретениям был максимальным. Наиболее низкий показатель заявок на изобретения наблюдался в 2016 году. Аналогичная картина наблюдалась по промышленным образцам. В тоже время по заявкам на полезные модели отмечался рост в 3,5 раза. Выдача патентов и свидетельств на изобретения оказалась минимальной в 2016

${ }^{209}$ https://volgastat.gks.ru/storage/medianbank/Поступление+патентных+заявок.htm 
году. Выдача патентов и свидетельств на полезные модели была максимальной в 2014 году. Динамика небольшого роста патентов на полезные модели могла быть связана с активизацией деятельности администрации области по поддержке среднего и малого бизнеса, активизированная избирательными компаниями по выборам и перевыборам губернатора области, в период 2014-2019гг. Одновременно, коэффициент изобретательской активности по Южному федеральному округу, определяемый как количество поданных заявок на выдачу патента на изобретение и полезную модель на 10000 тысяч населения в 2015 году против 2010 не изменился: 1,68 против 1,69. Одновременно доля капитальных вложений в научные исследования в Волгоградском регионе в общем объёме инвестиций, в процентах, снизилась с максимальной 0,58 в 2012 году до 0,1 в 2016году ${ }^{210}$.

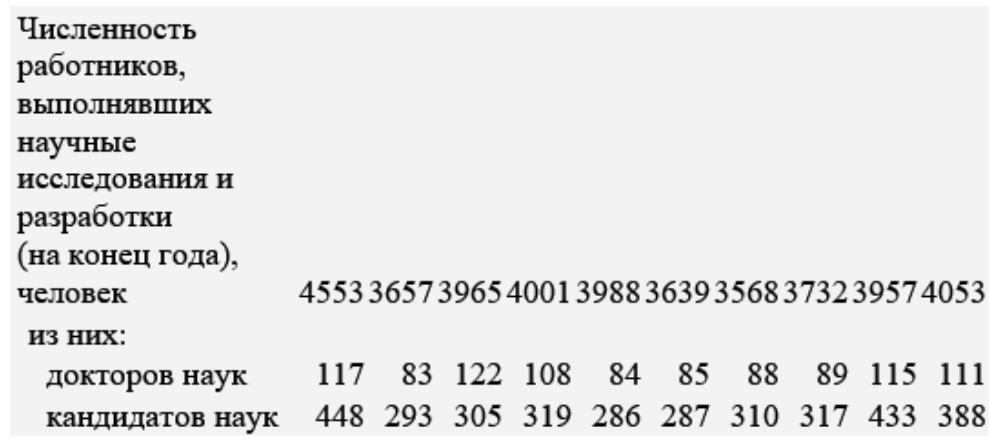

Параллельно снижению доли капитальных вложений в Волгоградском регионе, с 2007 по 2017гг снизилась и численность научных работников со степенью кандидата и доктора наук, выполняющих научные исследования и разработки на конец года.

210 Основные показатели состояния и развития науки в 2017-2016 году. https//volgastat.gks.ru/storage/mediabank/Основные+показатели+состояния+и+развития+науки_2007-2016.htm 
Возможные причины снижения региональных показателей патентной и изобретательской активности учёных и населения региона за период 2007-2017гг, помимо инвестиционного недофинансирования по линии капитальных вложений в науку, отражены в данных опросов врачей, с участием, по отдельным годам, до 10\% кандидатов и докторов медицинских наук.

Из 40\% опрошенных врачей, занимавшихся изобретательством, $10 \%$ его практически сразу оставляли. По мнению большинства респондентов (60\%) причины прекращения занятия изобретательством в отсутствии механизмов практической реализации изобретений. Среди проблем препятствовавших изобретательству статистически достоверно чаще врачи со стажем до 10 лет отмечали отсутствие материальной заинтересованности придумывать что-то новое $\left(\psi_{\text {тмф }}=4,56 ; \mathrm{p}<0,001\right)$, отсутствие материальной заинтересованности авторов внедрять свои изобретения $\left(\psi^{*}=2,86 ; \mathrm{p}<0,001\right)$, недостаточную поддержку изобретателей со стороны государственных и/или муниципальных органов власти ( $<<0,02)$, несовершенство законодательной базы в области изобретательства $(\mathrm{p}<0,001)$, отсутствие специальных структур которые бы работали с индивидуальными изобретателями $(\mathrm{p}<0,001)$.

В настоящее время в Российской экономике и медицине действительно практически отсутствуют структуры, работающие с физлицами изобретателями и занимающиеся качественным анализом изобретений, которые могли бы быть включены в государственные и муниципально-региональные инвестиционные проекты. Сегодня отбор изобретений для всероссийского внедрения осуществляет Роспатент, а точнее отраслевые отделы ФГУ ФИПС, ежегодно публикуя 100 лучших изобретений РФ. Однако работа Роспатента недостаточно эффективна.Публикация 100 лучших патентов далеко не исчерпывает потребностей в инновациях всех отраслей экономики, включая медицину. 
В то время как частное предпринимательство, не удостаивает своим вниманием индивидуальных изобретателей. Многие изобретатели создают свои изобретения на местах, в свободное от работы время. Хотя промышленная применимость таких изобретений не всегда очевидна, часто их результат направлен на реальное улучшение воспроизводства здоровья населения и увеличение нематериальных активов учреждений здравоохранения. Как известно, большинство таких изобретений создаются для нужд профессиональной деятельности и еще до патентования оказываются внедренными и фактически реализованы. Как показывает настоящее исследование, врачи со стажем свыше 10 лет статистически достоверно чаще создают и внедряют изобретения и, соответственно, демонстрируют более высокое социальное функционирование. Отсюда уровень социального функционирования врачей, в определенной степени, зависит от стажа работы по специальности. Этот вывод подтверждают результаты других исследователей. Так, по данным исследования 2012 года Н.В.Говорина и Е.А.Богданова, врачи г.Читысо стажем работы до 10 лет достоверно чаще, чем их коллеги со стажем более 10 лет $^{211}$ не удовлетворены материальным положением $(\mathrm{p}=0,001)$, жилищно-бытовыми условиями $(\mathrm{p}=0,01)$ и проведением отпуска $(\mathrm{p}=0,02)$.Для врачей с производственным стажем более 10 лет это социально менее значимо.

Как показано в настоящем исследовании отсутствие особых трудностей, которые встают перед изобретателями, достоверно чаще отмечали врачи со стажем работы до 10 лет ( $\left.\psi^{*}=1,87 ; \mathrm{p}<0,03\right)$. Объяснить противоречивость мнений врачей со стажем работы до 10 лет о наличии целого ряда препятствий при одновременном отсутствии особых

${ }^{211}$ Говорин Н.В., Богданов Е.А.Социальное функционирование и качество жизни врачей. ЭНИ. Забайкальский медицинский вестник.2012.№2.С.71-77. 
трудностей для занятия изобретательством, следует более низким уровнем их социального функционирования, а также более низкой профессионально-новационной информированностью в сравнении с врачами, имеющими производственный стаж более 10 лет. Это вывод подтверждает тот факт, что врачи со стажем работы до 10 лет достоверно чаще, по сравнению с более опытными коллегами, не знают о современных российских патентованных разработках по специальности, хотя более активно занимаются изобретательством. Очевидно, что для этой части врачей нет особых препятствий, так как они реже доводят свои изобретения до патентования и внедрения, когда возникает множество препятствующих проблем и трудностей. Для более опытных врачей имеется немало реальных препятствий. Среди них, как уже отмечалось - отсутствия специально работающих с изобретателями структур, отсутствие материальной заинтересованности разрабатывать $(48,2 \%)$ и внедрять $(46,9 \%)$ инновации.

Несовершенную законодательную базу в области изобретательства, отметили $27,8 \%$ врачей в качестве более или менее значимой проблемы $\left(\psi^{*}=3,60 ; \mathrm{p}<0,001\right)$. И это вполне закономерно, так как до сих пор окончательно не решен вопрос материальной заинтересованности авторов в разработке и внедрении потенциальных и реальных объектов патентного права. Несмотря на принятие, Государственной думой 4-й части ГК РФ 18.12.2006г, направленной на решение вопроса коммерциализации инноваций, в обществе идет горячая дискуссия о несовершенстве данного закона и его глав, незавершенности их разработки. С 1 января 2008 года вступила в силу четвертая часть гражданского кодекса Российской федерации, заменившая собой законы, ранее регулировавшие вопросы, связанные с интеллектуальной собственностью. В частности, прекратил действовать патентный закон Российской федерации. Однако ни в Патентном законе, ни в ГК РФ нет норм устанавливающих порядок 
выплаты вознаграждений авторам изобретений и полезных моделей. Этот порядок до сих пор регламентирует закон СССР от 31 мая 1991г №2213-1 «Об изобретениях в СССР». Согласно ст.12 Федерального закона Российской Федерации от 18 декабря 2006г №231-Ф3 «О введении в действие части четвертой Гражданского кодекса Российской Федерации» закон СССР «Об изобретениях в СССР» продолжает действовать (в части п.1. 3 и 5 ст.32 и 34) до принятия актов РФ о развитии изобретательства и художественно-конструкторского творчества. Из содержания ст.12 федерального закона видно, что вопрос выплаты авторских вознаграждений не входит в «компетенцию» Гражданского кодекса и этой проблеме на законодательном уровне не уделяется должного внимания ${ }^{212}$. Единственный акт, регулирующий в настоящее время порядок выплаты авторских вознаграждений, -закон СССР «Об изобретениях в СССР», который был принят в 1991 году. Этот закон не только устарел, но во многом практически не функционирует. Так п.5 ст. 32 гласит «Автору изобретения обладателем патента выплачивается поощрительное вознаграждение. Размер поощрительного вознаграждения за изобретение (независимо от количества соавторов) должен быть не менее среднего месячного заработка работника данного предприятия». На самом деле поощрительные вознаграждения авторам изобретений зачастую не выплачиваются. Поэтому, существующая в России система интеллектуальной собственности может лишь до некоторой степени компенсировать реализованную в конкретном продукте творческую деятельность автора, однако она не обеспечивает действительных инвестиций в его будущее творчество. В законодательстве ряда стран, куда не входит Россия, изъятие исключительного права, как правило, компенсируется предоставлением автору права

${ }^{212}$ Комашко.М.Н. «Выплата вознаграждений за служебные изобретения и полезные модели». Ж.Патенты и лицензии. 2008. № 5,C.45-49. 
на авторское вознаграждение. На нарушения прав авторов на авторское вознаграждение в Российском авторском обществе в области исполнительского искусства государство обратило внимание лишь в середине 2016 года. Так СМИ России 1 июля 2016г опубликовали информацию о возбуждении московскими следственными органами уголовного дела в отношении руководства Российского авторского общества (РАО) по статье 159 (часть 4) УК РФ (мошенничество, совершенное организованной группой лиц в особо крупном размере, наказание - от пяти до десяти лет) $)^{213}$. В рамках следственных действий в центральном офисе РАО произведены обыски с выемкой документов и копированием компьютерных баз. Один из центральных эпизодов, эпизод расследования перехода из собственности РАО в собственность его руководителя Сергея Федотова музыкального издательства «ММИ-Гармония», через которое проходили миллионы долларов, поступавшие со всего мира за исполнение музыки российских композиторов. Возбуждённое уголовное дело должно стать одним из самых громких по защите авторских прав в современной России. Это единичный прецедент подчеркивает масштабы нарушений прав авторов в России, которым не выплачивались и не выплачиваются авторские вознаграждения. Интерес следственных органов к бывшему руководителю РАО понятен, ведь имущество Российского авторского общества выводилось за рубежи России в виде операций с недвижимостью. Бывший руководитель РАО создал непрозрачный механизм отчислений авторских вознаграждений, при котором треть собранных денег фактически поступала в распоряжение «авторских обществ».

Недостаточную поддержку прав изобретателей со стороны государственных и муниципальных органов власти в

${ }^{213}$ Теневая империя Федотова-Михалкова. Новая газета. 01.07.2016. Электронный ресурс: http://www.rospres.com/ corruption/18841/ 
настоящем опросе отметили 28,8\%. Причем данный пункт оказался статистически достоверно более значимым для врачей со стажем до 10 лет ( $<<0,02)$, вероятно, из-за недостаточности материальных доходов. Этот вывод не противоречит результатам исследователей Н.В. Говорина и Е.А. Богданова качества жизни 383 врачей города Читы, в котором врачи со стажем работы до 10 лет достоверно чаще ( $\mathrm{p}=0,001)$, чем их коллеги со стажем более 10 лет, небыли удовлетворены своим материальным положением. Учитывая материальные затраты на творчество и его патентование, показатели обоих опросов должны были быть иными. В частности из-за финансовых вложений в оформление патента на изобретение в России, которые достаточно велики и составляют до 150 тысяч рублей/ на результат. Кроме того владелец патента на изобретение ежегодно оплачивает ежегодную пошлину от 1,5 и более тыс. рублей в зависимости от срока продления патента, тем большую, чем дольше патент действует или бездействует. Увеличению финансовых издержек изобретателей в немалой степени способствует постановление правительства РФ №941 от 10 декабря 2008года, в котором прописано увеличение ежегодной пошлины за Евразийский патент на 25\% от размера пошлины за подержание в силе патента РФ на изобретение. Из-за отсутствия средств, включая валютные, на поддержку изобретателей и патентование их изобретений, российские разработчики в медицинской и сопряженных с ней областях патентуют свои изобретения в основном только в России, что создает возможность безвозмездного копирования их изобретений в других странах ${ }^{214}$.

В последнее время в РФ стало больше закупаться технологически сложного импортного диагностического оборудования, требующего значительных средств.При

${ }^{214}$ Беляков В.К., Пивень Д.В., Антонов Д.П. «О проблемах инновационной политики в отечественном здравоохранении и необходимости создания кластеров медицинских инноваций».Ж. Менеджмент в здравоохрании.2008.-№1.,-С.4-11. 
этом здравоохранение экономически развитых стран, в немалой степени за счет использования инвестиций в изобретения, становиться все более технологичным. Диспропорциям способствует сложившаяся государственно-инвестиционная политика, недостаточно ориентированная на поддержание российских производителей патентных биотехнологий. Пример тому конференция «Инновации в здравоохранении: современность, международная практика и обмен опытом» состоявшаяся 22 февраля 2011 года, где зам. министра здравоохранения России Вероника Скворцова объявила о способности и готовности министерства здравоохранения России инвестировать в биомедицинские и биотехнологические разработки Великобритании достаточное количество средств и на длительный период времени ${ }^{215}$. При этом предполагалась ограниченность поставок инновационного оборудования. В то время как практическому здравоохранению России требовалось массовое обновление оборудования и медицинских технологий. В середине 2016 года СМИ сообщили, что практически каждая четвертая единица медицинской техники, закупленная по национальной программе «Здоровье» до 2007 года, начинает давать сбои и выходить из строя ${ }^{216}$. За 2007-2012 годы медорганизации России приобрели ${ }^{217}$ более 389 тыс. единиц оборудования, в том

215 Россия-Великобритания: совместные шаги на пути к инновационной фармацевтике в РФ./Ж Леч.Врач.,2011.-№3.-С.5.

216 Медтехника, купленная в рамках нацпроекта, начала выходить из строя..[Электронный ресурс]- http://www.zdrav.ru/ news/101922-qqn-16-m7-18-07-2016-medtehnika-kuplennaya-vramkah-natsproekta-nachala-vyhodit-iz-stroya?from=content_link.

${ }^{217}$ Регионы ждёт проверка модернизации медоборудования. [Электронный ресурс]- http://www.zdrav.ru/news/101979-regiony-jdet-proverka-modernizatsii-medoborudovaniya?utm_source= letternews\&utm_medium=letter\&utm_campaign=letternews_Z̄ drav_03082016_weekly_readers_52136/09.08.16. 
числе более 700 магнито-резонансных и компьютерных томографов, более 6,5 тыс. единиц рентгеновской техники и ангиографов.По данным того же источника в связи с высокой изношенностью и дефицитностью медицинского оборудования министр здравоохранения РФ Вероника Скворцова анонсировала массовую проверку медицинского оборудования в конце 2016 года.Как заявила министр обновление медоборудования стоимостью менее 100000 тыс. руб. заложено в тарифах оказания медицинской помощи, и его модернизация происходит за счёт базовой программы ОМС. «А вот тяжелое оборудование (более 100 тыс. руб за единицу) сейчас обновляется за счёт специальных резервных фондов, которые создаются в территориальных фондах ОМС для возможности обновления, ремонта и закупок». В силу лимита федерального финансирования, перевода практического здравоохранения и служб СПМ с 1 января 2013 на финансовое обеспечение из региональных бюджетов и фондов ОМС, адекватное удовлетворение в 2016 году и в последующие год-два потребностей здравоохранения в тяжелом, даже не импортном медоборудовании, проблематично.

Участие России в реализации программ внешней помощи TACIS co стороны EC не решало проблемы недофинансирования российского здравоохранения, так как TACIS не являлась инвестиционной программой. Средства, предусмотренные её бюджетом, не могли быть использованы непосредственно партнёром в качестве которого выступила Россия, для реализации своих собственных целей, в том числе для развития производства ${ }^{218}$. По заявкам российских организаций и при их непосредственном участии проекты программы Тасис осуществляли фирмы

${ }^{218}$ Водичев.Е.Г-эксперт ЕU Tacis Monitoring and Evaluation program/ Программа ТАСИС как фактор ускорения процессов формирования гражданского общества в России.[ Электронный ресурс]-htpp:// www.prof.msu.ru/publ/book3/vod.html. 
и компании, имеющие юридическую регистрацию в одной из стран ЕС, которые на выделенные деньги приобретали средства для осуществления того или иного проекта по результатам участия в общеевропейском (страны члены EC) тендере. Таким образом, за период 1991-99 гг., ЕС передало европейским компаниям по программе «Тасис» выделенные на Россию два миллиарда 48 миллионов евро. В 2000 году Российско-европейский центр экономической политики (РЕЦЭП), консультирующий российские органы государственного управления, получил очередной грант в размере лишь €2 млн. На новом этапе проекта в России Евросоюз был сосредоточен на четырех направлениях: поддержке институциональной, правовой и административной реформ; частного сектора; мер по ослаблению социальных последствий переходного периода; ядерной безопасности. Российско-европейский центр экономической политики был основан в 1995г и функционировал как регулярно возобновляемый проект до 2002г. В 2004г была начата пятая фаза проекта, в которой в качестве приоритетов были отмечены вопросы, изучаемые группами социально-экономических реформ и развития отношений между Европейским союзом и Россией ${ }^{219}$. Целью всех фаз проекта РЕЦЭП были задачи упорядочения институциональных условий функционирования бизнеса. Как указали авторы документа «Реформа бюджетного процесса в России 2004-2005 » эффективность функционирования российских предприятий оценивалась неоднозначно. Всего по программе Тасис ЕС потратил на Россиює2млрд. 50 млн $^{220}$. В области медицины проект Тасис назывался

${ }^{219}$ Реформа бюджетного процесса в России: 2004-2005. Под ред. В.Л.Тамбовцева. Москва.2005.[Электронный документ ]-htpp://www. recept.ru/files/budget_ru.pdf.

${ }^{220}$ The Tacis Information \& Communications Programme MEDIA MONITORING Tacis in the Russian Federation Period from 23.10.2000 to 28.10.2000. http:// www.recep.ru October 23 - 28 RUS.pdf 
«Система профилактических мер и здоровье населения России». Автор участвовал в конференциях в рамках проекта Tacis (Тасис) и публикация ${ }^{221}$ материалов ${ }^{222}$ конференций ГНИЦ Профилактической медицины проводившихся в Санкт-Петербурге и других регионах участвовавших в данном проекте.

Деньги, выделенные ЕС по программе Тасіs для здравоохранения России были успешно освоены европейскими компаниями. Институциональная реформа Российских медицинских новаций осталась без внимания и финансовой поддержки со стороны ЕС и его проекта Tacis.

В декабре 2012 года в Брюсселе политические лидеры обеих сторон объявили 2014 год «Годом науки Россия-ЕС». Заявленный как «годовой цикл мероприятий и инициатив содействия сотрудничеству России и ЕС в области науки, высшего образования и инноваций, год науки Россия-ЕС носил кратковременный характер, не оказав влияния на проблемы практической медицины.

В середине 2016 года медицинское оборудование, поставленное по ПНП «Здоровье» было изношенным, каждая 3-4-я единица медицинского оборудования оказалось не работоспособной, что повсеместно способствовало замещению бесплатной медпомощи платными услугами,

${ }^{221}$ Апухтин А.Ф., Стаценко М.Е., Краюшкин С.И. Оптимизация антигипертензивного лечения при спастико-трофическом характере нарушения периферического кровообращения. Актуальные проблемы профилактики неинфекционных заболеваний Всероссийская научная конференция с международным участием 18-19 ноября 2003.Матералы докладов.Редакционная комиссия: Р.Г.Оганов, С.А.Шальнова, И.Н.Ильченко. Москва 2003. С.10.

222 Апухтин А.Ф.,Апухтина М.В. Клинико-физиологические аспекты оперативного контроля кровообращения и кислородного баланса ткани у здоровых и больных ИБС. Актуальные проблемы профилактики неинфекционных заболеваний. Научно практическая конференция с международным участием 2-4 декабря 1997. Тезисы докладов. Москва 1997. С.10-11. 
начиная с 2008г. Об этом свидетельствуют результаты 2008 года комплексного исследования в целом состояния диагностической службы в г.Омске и в ее отдельных подразделениях. Недостаточная оснащенность высоко технологичным оборудованием и недостаточная доступность его в ЛПУ г.Омска в то время была отмечена врачами ${ }^{223}$ в качестве существенной причины внедрения системы платных медицинских услуг и ограничения доступности медпомощи для населения данного региона. Спустя восемь лет в 2016 году по инициативе районной прокуратуры Волгоградской области главный врач Фроловской ЦРБ Н.Бурмистрова была привлечена к ответственности за навязывание пациентам платных медицинских услуг ${ }^{224}$. Обращает внимание то, что дефицитность оборудования не была отмечена в качестве причины данной «инновации», а оказанные платные услуги входили в перечень исследований клинико-диагностической лаборатории больницы и должны были предоставляться бесплатно.

По данным экономического эксперта И.Б.Назаровой 225 , кардинальные изменения в системе здравоохранения, связанные с переводом медицинских услуг на платную основу не просто ограничивают, а значительно снижают доступность медицинской помощи. В связи с этим в середине 2016 года правительство РФ внесло в Госдуму законопроект, в котором предложило штрафовать

223 Федорова Г.В., Редькин. А.В. «Мнение врачей - клиницистов о состоянии диагностической службы в лечебно-профилактических учреждениях». //Ж.Здравоохранение Российской Федерации.-2008.-№ 4.-С.40-41.

${ }^{224}$ Сурагина О. Медиков решили наказывать рублем..Волгоградская правда. 20.07.2016. URL ресурс: http://vpravda.ru/News/ Society/10163

${ }^{225}$ Назарова И.Б.Здоровье и самостоятельное поведение занятого населения России: Автореф. дисс..д-ра экон.наук.-М.,2007. 
больницы и поликлиники за отказ в бесплатной помощи по полисам ОМС и нарушение порядка ее оказания, а врачей за выписанные не по инструкциям лекарства и анализы ${ }^{226}$. Планировалось запретить выписку пациентам рецептов с торговыми наименованиями лекарственных препаратов, поскольку это трактуется как помощь в продвижении лекарств конкретного производителя. Размер штрафа для врачей составляет 3-5 тыс. рублей, для руководителя медорганизации - 5-10 тыс. рублей. Если прецедент повторяется, нарушителя могут лишать права работать в медицинской сфере на шесть месяцев. Разработчики законопроекта предложили штрафовать медучреждения на сумму до 40 тыс. рублей за отказ в оказании бесплатной медпомощи по полису ОМС (или попытку взимать деньги за эти услуги). По данным публикации О.Сурагиной (2016), цитирующей мнение председателя Волгоградского обкома профсоюза работников здравоохранения Ирины Ерохиной: «..штрафовать медицинские организации за отказ пациентам оказывать бесплатно медицинскую помощь это перекладывание проблемы с больной головы на здоровую. Для начала надо решить вопрос с должным финансированием системы здравоохранения».

Сложившаяся ситуация с недостаточным финансированием здравоохранения по логике мышления должна благоприятствовать политике врачебных новаций в практическом здравоохранении. Но на фоне недостаточного финансирования здравоохранения, недостаточной доступности бесплатной медицинской помощи на самом деле оказались не востребованными врачебные инновационные технологические разработки. Это подтверждают результаты выполненного автором в 2009-2010 гг. опроса врачей Волгограда, в котором установлена экономически

${ }^{226}$ Сурагина О. Медиков решили наказывать рублем..Волгоградская правда. 20.07.2016. URL ресурс: http://vpravda.ru/News/ Society/10163 
недостаточно эффективная 33\%инновационнаяактивность практических врачей ${ }^{227}$.

Важным шагом формирования инновационной политики является разработанная Министерством экономического развития РФ концепция долгосрочного социально-экономического развития России на 2008-2020гг. В этой связи возникла необходимость в формировании отраслевой инновационной политики в здравоохранении. По мнению экспертов патентоведов потребность в разработке и внедрении медицинских инноваций остаётся не только очень высокой, но и в перспективе будет только нарастать ${ }^{228}$. При этом очевидно, что существующие трудности внедрения инновационных методов контроля за лечением больных

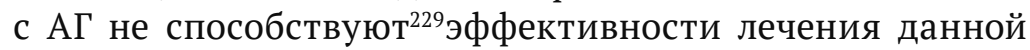
сердечно-сосудистой нозологии, так как существовавшие в тот период времени рекомендации не обеспечили достижения целей поставленных ПНП Здоровье в 2006-2007годах: «Снижение у больных хроническими заболеваниями, по сравнению со случаями заболеваний в 2005 году, частоты обострений и осложнений не менее чем на 30 \% и снижение временной нетрудоспособности населения не менее чем на $20 \% 230$ »; Об этом свидетельствует анализ данных обращаемости за услугами скорой медпомощи (СМП)

${ }^{227}$ Апухтин А.Ф.,Деларю В.В., Егоров В.Н.. Прочная В.Л. Мнения врачей о разработках и внедрениях отечественных инновационных технологий в здравоохранение. Ж.Социология медицины.,№2(17).2010.С28-30.

228 Вакуленко. И.М. «В чем особенности правовой защиты изобретений в области медицины?». Ж.Патенты и лицензии. 2008.,№12.,C.45-48.

229 Апухтин А.Ф. Состояние периферического кровообращения и тканевого обмена кислорода у больных гипертонической болезнью в зависимости от антигипертензивной терапии. Автореф. дисс. канд. мед.наук. Волгорад.2004.23с.

${ }^{230}$ Электронный ресурс.Режим доступа: http://newsruss.ru/doc/ index.php /ПНП_«Здоровье» 
Мытищинского муниципального района Московской области из которого следует ${ }^{231}$, что в период с 2004 по 2008гг. артериальная гипертензия по частоте обращаемости и числу сосудистых осложнений являлась одной из наиболее важных и нерешенных проблем первичной медико-санитарной помощи. По этому разделу патологии, как указывал источник, в большом проценте случаев (>25\%) СМП выполняла замещение функций амбулаторно-поликлинических учреждений. Вместе с этим, за анализируемый период времени в работу СМП района были осуществлены единичные инновации. В частности, были внедрены: новое изделие медицинского назначения - 3-х канальные электрокардиографы Fukuda, и из «новых» - препараты Энап в/в и нифедипин под/язык. Последний препарат, используется в клинической практике уже 20 лет, и он не инновационный. Обращает внимание отсутствие указаний на внедрение в работу СМП других средств оказания неотложной помощи больным АГ.

Проблемы оказания эффективной медпомощи больным артериальной гипертензией и сахарным диабетом, а также препятствия к внедрению российских инноваций во многом схожи для различных субъектов РФ, включая регионы Волгограда, Москвы и Омска. Очевидно, что в существующей федеральной структуре управления интеллектуальной собственностью, не выполняется главная задача государства по созданию благоприятных условий для повсеместного развития и поддержки разработок и изобретательской врачебной деятельности, удовлетворяющей потребности современного воспроизводства здоровья населения ${ }^{232}$.

231 Рождественский В.Е., Рождественский М.Е., Пригородова Ю.В./Артериальная гипертензия как проблема скорой медицинской помощи.// Четвертый национальный конгресс терапевтов (XX Съезд российских терапевтов). Сборник материалов.г.Москва.,2-4 декабря 2009г.-С.210-211.

232 Барщевский М. Когда знания -деньги. Российская газета, №45(5125), 2010.,C8. 
По мнению критиков, несмотря на благие намерения кураторов национального проекта «Здоровье», существенно изменить ситуацию в здравоохранении не удалось. Некоторые эксперты в конце 2009г определили нацпроект «Здоровье» как провальный 233.

Спустя 10 лет после начала реализации ПНП «Здоровье ${ }^{234}$ премьер министр России Дмитрий Медведев дал оценку проекту Здоровье «...проект помог изменить ситуацию в этой сфере, но не решил всех проблем» ${ }^{235}$.Согласно сообщению ТАСС от 27 июля 2016 года премьер-министр РФ Дмитрий Медведев сообщил, что на одном из ближайших заседаний президиума Совета по стратегическому развитию будет обсуждаться новый национальный проект по здравоохранению. Неизвестно, изменится ли с приходом нового ПНП проекта «Здоровье» врачебные мнения о разработке и внедрению в медицину инноваций, включая врачебные.

${ }^{233}$ Башкатова.А. Забытые нацпроекты.Независимая газета.29.12.09. Электронный ресурс.-Режим доступа: http://www.ng.ru/ economics/2009-12-29/1_nazprojects.html

${ }^{234}$ Приоритетный национальный Проект «Здоровье» проводится с 2006г.Идея национальных проектов как «курса на инвестиции в человека, а значит - в будущее России» была заявлена В. Путиным в эпоху президентства 2005 года, когда к приоритетным направлениям он отнес здравоохранение, жилье, образование и сельское хозяйство. Позже тема нацпроектов активно использовалась в период предвыборной кампании Д. Медведева в 2008 году.

${ }^{235}$ Медведев Д.: Совет по стратегическому развитию обсудит новый нацпроект по здравоохранению. Электронный ресурс.-Режим доступа: http://tass.ru/obschestvo/3490200http://tass.ru/ obschestvo/3490200 


\section{Результаты}

1. $40 \%$ практических врачей города Волгограда занимаются изобретательством, но через непродолжительное время четвертая часть оставляют занятия изобретательством. Ещё около 5 \% изобретают, но не внедряют изобретения в основном из-за отсутствия механизмов их практической реализации. В среднем $25 \%$ врачей проявляют активность в вопросе внедрения своих изобретений.

2. Среди проблем препятствующих изобретательству в порядке убывания частоты статистически достоверно чаще врачи со стажем до 10 лет отмечают отсутствие материальной заинтересованности (48,2\%) авторов придумывать что-то новое ( $\mathrm{p}<0,001)$, отсутствие материальной заинтересованности (46,9\%) авторов внедрять свои изобретения $(\mathrm{p}<0,001)$, недостаточную поддержку (28,8\%) изобретателей со стороны государственных и/ или муниципальных органов власти $(\mathrm{p}<0,02)$, несовершенство законодательной базы $(27,8 \%)$ в области изобретательства (p<0,001), отсутствие специальных структур (13,9\%) которые бы индивидуально работали с изобретателями ( $<<0,001)$.

3. Лишь небольшое количество врачей $(3,1 \%)$, в основном не занятых внедрением изобретений считают, что перед изобретателями нет никаких проблем.

4. Подавляющее большинство врачей, а это 84,9\% интервьюированных, не отметило способствования ПНП «Здоровье» разработке и внедрению в медицину российских изобретений.

5. Институализация практики внедрения врачебных инноваций свидетельствует о необходимости совершенствования нормативно-правовой базы 
коммерциализации инноваций, как на федеральном, так и на региональном уровнях.

6. Модель оптимизации институализации медицинских инноваций может быть представлена совокупностью процессов: а)инициирование формирования заинтересованных во врачебно-медицинских инновациях социально-государственных структур с совершенствованием взаимоотношений с разработчиками и авторами изобретений и инноваций; б)развитие государственной практики создания налоговых преференций для предприятий и индивидуальных предпринимателей использующих врачебные инновации и проводящие поощрительные выплаты по ним авторам изобретений; в)введение государственной практики зачета биомедицинских изобретений в качестве залогового капитала для получения льготных банковских кредитов и последующих расчетов по ним. 


\section{ВЫВОДЫ}

1.На государственно-законодательном уровне необходимо создание стабильного законодательно-правого поля для адаптации субъектов патентного права к предлагаемым государством моделям легального взаимодействия с обществом в медицинской сфере инновационной деятельности.

2.Для улучшения оценки и совершенствования механизмов реализации взаимодействия социальных субъектов с региональными структурами власти необходима предварительная локальная апробация вновь вводимых нормативных документов и предсказуемость действия местных управленческих структур.

3. Для поддержки и финансового стимулирования медицинских, в первую очередь врачебных инноваций целесообразно активное участие саморегулируемых врачебных организаций для внесения предложений: а)в департамент анализа, прогноза и инновационного развития здравоохранения РФ по включению в разрабатываемые стандарты медицинской помощи патентных врачебных разработок; б) в СМО дополнительных выплат по стандарту оказания медпомощи с использованием патентной медицинской врачебной инновации.

4.С целью совершенствования поддержки инноваций со стороны государства необходимо изменение федерально-регионального законодательства по упрощению регистрации и получению разрешения применения патентных инновационных биотехнологических разработок;

6. Для повышения инвестиций в биомедицинские инновационные проекты необходимо дальнейшее 
совершенствование и изменение регионального законодательства в области снижения налогообложения предприятий, компаний и других юридических и физических правообладателей патентных биомедицинских технологий;

7. Для поддержки инновационных предприятий малого и среднего бизнеса, занятых в сфере биомедицинских технологий необходимо снижение административных барьеров на пути регистрации и получения разрешений применения патентных биомедицинских технологий с возможностью упрощённого пролонгирования сроков статуса инновационного предприятия при наличии необходимого объема подтверждающих документов;

8. Для формирования кадрового потенциала успешно реализующего инновационную деятельность необходимо формирование в гуманитарных ВУЗах специальных дополнительных образовательных программ для студентов, врачей и молодых ученых, с упором на исследовательскую работу, разработку, практическое внедрение и коммерческое применение результатов интеллектуальной деятельности;

9. С целью максимального снижения высоких рисков и привлечения наибольшего количество инвесторов необходимо создание системы страхования высоких рисков при инвестировании в патентно-инновационные биомедицинские технологи и проекты (в том числе частно-государственные), законодательно учитывающей возможность поэтапного (траншевого) инвестирования и единовременного материального вознаграждения авторов патентных продуктов и изобретений;

10. Для популяризации положительных примеров, «историй финансового успеха»- ученых, инвесторов, 
практических врачей, предпринимателей малого и среднего бизнеса в области биомедицинских технологий необходима разработка и применение региональных инструментов информационной поддержки их деятельности;

11. Для увеличения инвестиций в медицинские биотехнологии необходимо снижение кредитных ставок банковского капитала, введение льготного кредитования разработчиков инновационных проектов и продуктов, с зачётом их залоговой стоимости при кредитовании;

12. Для успешного продвижения медицинских инноваций в России необходимы достаточно четкая налаженность коммуникаций между носителями идей и капитала, ликвидация «деловой безграмотности» изобретателей (врачей и студентов), приобретение умения представлять свои разработки потенциальным инвесторам с экономической точки зрения. Для этого в системе дипломного и последипломного образования необходимо формирование специального междисциплинарного блока знаний по вопросам инновационной деятельности в сфере разработки и подготовки практического освоения нововведений, организации информационных, консалтинговых, социальных и других видов услуг.

13. Очевидна актуальность социологических исследований проблем российского здравоохранения в ближайшие годы.

$$
\text { **** }
$$

По мнению экономических экспертов ${ }^{236}$, есть основания считать, что одной из ключевых задач России на

${ }^{236}$ Королёва Е.В. Формирование и развитие патентно-информационной поддержки новаций. Дисс. докт.экон.наук.Санкт-петербург.2015.374c. 
ближайший период времени должны стать активизация научной и инновационной деятельности, стимулирование фундаментальной и прикладной науки, увеличение вложений средств в исследования и разработки, поощрение изобретательской активности, создание эффективных механизмов коммерциализации результатов НИОКР, подготовка кадров для инновационной экономики.

Содержание монографии созвучно с высказыванием президента лиги защиты пациентов А.Саверского: «Сегодня, когда накоплен огромный опыт, пора говорить и мыслить категориями технологий. Кроме того, врач-творец никогда не попадёт в суд, потому-что такие люди вообще не ординарны, их пациенты выживают против всех законов биологии: Может ли вся медицинская индустрия стоять на таких врачах? Ясно, что на всех пациентов таких врачей не хватит. Что же тогда спасёт пациента от «врачакак-бы творца», рассуждающего как творец, самоуверенного как творец, но не умеющего творить? Только обязанность врача выполнить требования технологии, чтобы не изобретал, раз не умеет!» ${ }^{237}$

Что ещё к этому добавить? Разумно добиваться, чтобы больше действующих и будущих врачей умели изобретать, и становились как-бы «творцами» спасающими жизнь пациентам в повседневной профессиональной деятельности. В тоже время никто не освобождает врача от выполнений требований технологии и клинических рекомендаций в первичном звене здравоохранения. Президент России Владимир Путин во вторник, 20 августа 2019 года, провел заседание с членами правительства, на котором раскритиковал ситуацию в первичном звене

${ }^{237}$ Саверский А.В., Сергеева Е.О Значение протоколов ведения больных в судебной практике. Ж. Проблемы стандартизации в здравоохранении. 2005. №11. С.6-12). 
здравоохранения. Глава государства дал ряд поручений 238 , чтобы все исправить: « Если первичное звено здравоохранения у нас будет в том состоянии, в котором оно находится до сих пор, то количество инфарктов и инсультов не уменьшится. Потому что в первичном звене провал. Поэтому, безусловно, нам нужно принять дополнительные меры по укреплению первичного звена здравоохранения. Напомню еще раз, мы дважды это делали из федерального центра в расчете на то, что это будет подхвачено на местах, в регионах, но этого не происходит. И в этой связи нам, безусловно, нужно посмотреть на всю организацию этой работы. Это очевидный факт, просто очевидные вещи. Конечно, у них в регионах своя компетенция, и нужно ее поддерживать, но что-то там, видимо, до конца эффективно не работает. На это нужно обратить внимание». Вот только будет ли «обращено внимание» на «свои-врачебные» компетенции на местах и будут ли они подхвачены и поддержаны? Пациенты справедливо жалуются на плохие условия, очереди к врачам специалистам и их нехватку. Медицинские работники в свою очередь недовольны уровнем заработной платы и высокой нагрузкой.

${ }^{238}$ Совещание по вопросам модернизации первичного звена здравоохранения http://www.kremlin.ru/events/president/news/61340 


\section{Список публикаций по теме монографии}

1. Апухтин А.Ф., Инина Л.И. Изменение показателей качества жизни больных сахарным диабетом при включении в базисную терапию омега-3-ПНЖК. Сборник материалов VIII национального конгресса терапевтов. Москва, 22-24 ноября 2013.М.: ООО «Бионика медиа»Редактор Жданова Е.Р. С.12-13.

2. Апухтин А.Ф. ,Инина Л.И.Коррекция депрессивных и болевых расстройств у больных сахарным диабетом тип 2 комбинированной гиполипидемической терапией. Сборник материалов конгресса «Человек и лекарство» (тезисы докладов) 2013г.ЗАО РИЦ «Человек и лекарство» 15-19 апреля 2013.Москва.С.251.

3. Апухтин А.Ф. Проблемы институализации интеллектуальной собственности в отечественном здравоохранении глазами студентов и врачей. Социальные и гуманитарные науки: теоретические и прикладные исследования. /Сборник научных статей // Северо-Кавказский научный центр высшей школы южного федерального университета. Ростов-н/Дону, 2013., С.63-67. ISBN 978-5-87872-696-2;С.63-67;

4. Апухтин А.Ф. ,Инина Л.И.Изменение показателей качества жизни б-х сахарным диабетом при включении в базисную терапию омега-3 ПНЖК. Восьмой национальный конгресс терапевтов./Сборник материалов./ Москва,22-23 ноября 2013г.Ред. Жданов Е.Р. М:ООО«Бионика Медиа».С.12-13.-400с.

5. Апухтин А.Ф. Проблемы развития личности студентов последней ступени образования. Materialy $\mathrm{X}$ Miedzynarodonowej naukowi-praktycznej conference Naucowa Mysl informacy V21. 07. marca 2015.-P.16-18. 
6. Апухтин А.Ф. Состояние врачебно-новационного капитала в здравохранении. Экономика, социология и право. 2014. № 4. С. 121-124.

7. Апухтин А.Ф., Апухтина М.В.Проблемы развития последней ступени профессионального образования: в фокусе объекты авторского права.Гуманитарные и социальные науки. 2014. № 2. С. 358-360.

8. Апухтин А.Ф. Стратегия инновационного развития здравоохранения в компетенциях врачебных кадров. ЭНИ изд-е. Забайкальский медицинский вестник. 2014. № 1. С. 94-97.

9. Апухтин А.Ф. Мнения врачей о технической оснащенности регионального здравоохранения и внедрениях врачебных новаций за пять лет. Вестник Волгоградского государственного медицинского университета. 2014. № 2 (50). C 17-19.

10. Апухтин А.Ф.,Иванова Д.А.,Апухтина М.В. Клинико-диагностическое значение определения тканевого баланса кислорода для оценки ремоделинга сердца и клинического статуса больных хронической сердечной недостаточностью. На стыке наук. Физико-химическая серия. Материалы II международной научной интернет-конференции: в 2 томах; составитель Д.Н. Синяев. Сервис виртуальных конференций Pax Grid; ИП Синяев Д. Н. 2014. С. 15-17.

11. Апухтин А.Ф.Институциональная среда развития инновационного потенциала в здравоохранении, перспективы и реальности. Информационные технологии в медицине и фармакологии. Сборник научных трудов по итогам международной научно-практической конференции. ИЦРОН. 2014. С. 93-96.

12. Апухтин А.Ф. Мульти парадигмальность развития новационного потенциала в региональном 
здравоохранении, возможности консенсуса. Основные проблемы общественных наук. Сборник научных трудов по итогам международной научно-практической конференции. Инновационный центр развития образования и науки. 2014. С. 62-65.

13. Апухтин А.Ф. Психологическая неготовность и новационная некомплаентность практических врачей и студентов: фокус на дополнительное образование. В сборнике: Инновация в образовании. Современная психология в обучении. Материалы III-й международной научной интернет-конференции. ИП Синяев Д. H.,2014. C. 4-6.

14. Апухтин А.Ф. Дополнительный сахароснижающий эффект омега 3 пнжк у больных сахарным диабетом: фокус на безопасность комбинированной гиполипидемической терапии. Липидология - наука XXI века. Материалы I-й международной научно-практической интернет-конференции.ИП Синяев Д. Н., 2014. С. 27-28.

15. Апухтин А.Ф. ,Краюшкин С.И. Завершающая ступень профессионального образования: в фокусе вопросы авторского права. Качество жизни, психология здоровья и образование: междисциплинарный подход. Материалы Международной научно-практической конференции. Москва, РУДН, 24-25 апреля 2014. С. 26-27.

16. Апухтин А.Ф. Стагнация психологического развития личности студентов последней ступени профессионального образования: фокус на психологию развития новаций. Психология развития и стагнации личности в рамках современного общества. Материалы II Международной научно-практической Интернет-конференции. Система виртуальных конференций Pax Grid; ИП Синяев Дмитрий Николаевич. 2014. С. 12-14. 
17. Апухтин А.Ф. ,Апухтина М.В.Психологические проблемы и трудности инновационного развития практической медицины регионального уровня. Медицина в XXI веке: тенденции и перспективы. Материалы III Всероссийской научной Интернет-конференции с международным участием. Сервис виртуальных конференций Pax Grid; ИП Синяев Д. Н.. 2014. С. 12-13.

18. Апухтин А.Ф. Актуальные вопросы кадровых и иновационных потерь в практическом здравоохранении.Актуальные вопросы и перспективы развития медицины. Сборник научных трудов по итогам международной научно-практической конференции. Инновационный центр развития образования и науки. 2014. С. 114-116.

19. Апухтин А.Ф., Инина Л.И. Динамика микрореологического профиля больных сахарным диабетом при курсовой гиполипидемической терапии. Ж. Терапия. Изд-во ВолгГМУ. 2015. № S. C. 9-10.

20. Апухтин А.Ф. Творческий вклад врачебно-креативного потенциала в развитие здравоохранения Волгограда. Wschodnioeuropejskie Czasopismo Naukowe. 2015. T. 1. № 1. C. 111-114.

21. Апухтин А.Ф. Врачебные новации в здравохранении: в фокусе пути развития в системе ОМС. Национальная Ассоциация Ученых. 2015. № 8-3. С. 54-56.

22. Апухтин А.Ф. Врачебная оценка новационного потенциала в здравоохранении. Национальная Ассоциация Ученых. 2015. № 4-6 (9). С. 139-

23. Апухтин А.Ф. Гиполипидемическая коррекция микрососудистых нарушений у больных сахарным диабетом. Теоретические и прикладные аспекты современной науки. 2015. № 7-6. С. 8-10. 
24. Апухтин А.Ф. Характер инвестиций в региональном здравоохранении по мнению врачей и средств информации. Теоретические и прикладные аспекты современной науки. 2015. № 7-6. С. 10-12.

25. Апухтин А.Ф. Изобретательская активность и профессиональная удовлетворенность в региональной медицине. Ежемесячный журнал Евразийский союз ученых. 2015. № 12-5 (21). С. 15-17.

26. Apukhtin A.F. Problems of development of personality of students of the last stage of professional education: focus on the fundamentals of the rules of innovations. Nauka $i$ studia. 2015. T. 12. C. 215-218.

27. Апухтин А.Ф. Пути формирования врачебных новаций в системе обязательного медицинского страхования. Экономика, финансы и менеджмент: тенденции и перспективы развития. Сборник научных трудов по итогам международной научно-практической конференции. ИЦРОН. Волгоград, 10 октября 2015. С. 247-251.

28. Апухтин А.Ф. Патентно-изобретательская активность медицины регионального уровня в оценках врачей. Перспективы развития современной медицины Сборник научных трудов по итогам международной научно-практической конференции. 2015. С. 159-161.

29. Апухтин А.Ф. Реологический профиль больных сахарным диабетом тип 2 при комбинированной гиполипидемической терапии. Проблемы медицины в современных условиях . Сборник научных трудов по итогам международной научно-практической конференции. 2015. С. 139-141.

30. Апухтин А.Ф. Problems and inventive activity the medicine of the regional level in the assessments of doctors. Materials of the IX international research and practice conference: Science, technology and higher education. Accent Graphics communications-Westwood Canada. December 23-24 
Appearance 20.01. 2016. P.147-151.The publisher-Strategic Studies Institute.

31. Апухтин А.Ф. Особенности гемореологического статуса микрососудистого русла у больных диабетом 2-го типа при гиполипидемической терапии. Сборник: На стыке наук. Физико-химическая серия III Международная научная Интернет-конференция. ИП Синяев Д. Н.. 2015. С. 24-27.

32. Апухтин А.Ф. Инновационные трансформации историко-культурных традиций сферы здравоохранения. Сборник материалов II Всероссийской научной интернет-конференции с международным участием.: Материальное и духовное наследие общества со времен возникновения до наших дней. ИП Синяев Д. Н.. 2015. C. 4-8.

33. Апухтин А.Ф. Вопросы формирования творческого развития личности глазами студентов медиков. Сборник материалов III МНК Интернет - конференции.: Психология развития и стагнации личности в рамках современного общества . ИП Синяев Д. Н., 2015.С.8-10.

34. Апухтин А.Ф. Коньюнктурные проблемы и трудности новационного развития практической медицины регионального уровня. Медицина в XXI веке Тенденции и перспективы IV Международная научная Интернетконференция:Сборник материалов конференции. ИП. Синяев.Д.Н. Сервис виртуальных конференций: Рах Grid. г.Казань, 2015. С. 10-12.

35. Апухтин А.Ф. Внеаудиторная изобретательская деятельность студентов медицинского ВУЗа. Инновационные технологии в науке и образовании. 2016. № 3 (7). C. 144-146.

36. Apukhtin A.F. Extracurricular inventive activity of medical students. International Journal of Applied and Fundamental Research. 2016. № 5. C. 1. 
37. Апухтин А.Ф. Изобретательская активность врачей в практической медицине. Международный журнал экспериментального образования. 2016. № 12-1. С. 41-42.

38. Апухтин А.Ф.Компетентность студентов медиков в сфере интеллектуальной собственности. Международный журнал экспериментального образования. 2016. № 12-1. С. 21-22.

39. Апухтин А.Ф.Инновационная активность и удовлетворенность профессиональной деятельностью врачей в Волгоградской области. Электронное изд-е.Ж. Забайкальский медицинский вестник. 2016. № 1. С. 49-52.

40. Апухтин А.Ф.Проблемы патентно-изобретательской активности в региональной медицине. Проблемы внедрения результатов инновационных разработок. Сборник статей Международной научно-практической конференции. ООО Омега Сайнс.(Уфа) Пенза, 18 июня 2016. C. 252-254.

41. Апухтин А.Ф. Применимость медицинских технологий закрытых патентами, не решенные вопросы. Основные проблемы в современной медицине. Сборник научных трудов по итогам международной научно-практической конференции. ИЦРОН,11октября 2016. С. 195-201.

42. Апухтин А.Ф.Контент внеаудиторной изобретательской деятельности в оценках студентов медицинского вуза. III МНПК О вопросах и проблемах современных общественных наук. Сборник научных трудов по итогам международной научно-практической конференции 11 июля 2016г. Г.Челябинск.Инновационный центр развития образования и науки. ИЦРОН.2016. С. 21-23.,28c.

43. Апухтин А.Ф. Изобретательская активность и удовлетворенность профессией врачей в региональной 
медицине. Актуальные вопросы медицины в современных условиях Сборник научных трудов по итогам международной научно-практической конференции. ИЦРОН, 11 января 2016. С. 109-111.

44. Апухтин А.Ф. Удовлетворенность профессией врачей занятых новациями. Медицина и фармакология: научные приоритеты учёных Сборник научных трудов по итогам международной научно-практической конференции. ФЦНиО Эвенсис. 25 ноября 2016. С. 85-89.116с.

45. Апухтин А.Ф. Медицинские технологии закрытые патентами: от вопросов к решениям.Медицина и фармакология: от вопросов к решениям. Сборник научных трудов по итогам международной научно-практической конференции. Институт инновационных технологий. Томск, 25 октября 2016. С. 41-46.

46. Апухтин А.Ф. Изменения микроциркуляторного реологического профиля больных сахарным диабетом при гиполипидемической терапии. Взаимодействие науки и общества: проблемы и перспективы. Сборник статей международной научно-практической конференции. ООО Аэтерна (Уфа) 1 марта 2016. Ответственный редактор: Сукиасян А. А. С. 138-139.

47. Апухтин А.Ф., Инина Л.И.Состояние микроциркуляторного реологического профиля больных сахарным диабетом при гиполипидемической терапии. В книге: Кардиология на перекрестке наук Тезисы докладов VII Международного конгресса совместно с XI Международным симпозиумом по эхокардиографии и сосудистому ультразвуку, XXIII ежегодной научно-практической конференцией «Актуальные вопросы кардиологии». Тюменский кардиоцентр, 11-13 мая 2016. С. 29-30.

48. Апухтин А.Ф. Современные достижения и разработки в области медицины и фармакологии. Сборник науч-х 
трудов по итогам МНПК Совр достижения и разраб-ки в области медицины и фармакологии / ФЦНиО Эвенсис. Оренбург 25 сентября 2016. Том Выпуск I, С.58.

49. Апухтин А.Ф. Проблемы современной медицины: актуальные вопросы. Сборник научных трудов по итогам международной научно-практической конференции / ИЦРОН. Красноярск 331с.2016. Том Выпуск III.

50. Апухтин А.Ф. Применимость медицинских технологий закрытых патентами, не решенные вопросы. Основные проблемы в современной медицине.Сборник научных трудов по итогам международной научно-практической конференции / Волгоград 11 октября 2016. Том Выпуск III; C.195-201.

51. Апухтин А.Ф. Основные проблемы в современной медицине. Сборник трудов МНПК. г.Волгоград, 11 октября 2016.232с.Том.Выпуск III

52. Апухтин А.Ф. Современные достижения и разработки в области гуманитарных наук.Сборник научных трудов по итогам международной научно-практической конференции / ФЦНиО-Федеральный Центр Науки и Образования «Эвенсис». 2016. Том Выпуск I.21с.

53. Апухтин А.Ф. Перспективы развития современной медицины Сборник научных трудов по итогам международной научно-практической конференции / ИЦРОН-Ииновационный Центр Развития Образования и Науки. Воронеж. 11 декабря 2016. 224c. Выпуск III.

54. Апухтин А.Ф. Особенности учебного процесса на клинической кафедре медицинского вуза. Инновационные технологии в науке и образовании. 2017. № 1-1 (9). C. 221-222.

55. Апухтин А.Ф. Клинико-прогностическое значение состояния миокарда и тканевого обмена кислорода 
у больных сердечной недостаточностью. В сборнике: Актуальные вопросы современной медицины сборник научных трудов по итогам международной научно-практической конференции.ИЦРОН.Екатеринбург 11 марта 2017. С. 70-73.

56. Apukhtin A.F.The functional state of the myocardium and tissue oxygen exchange in patients with heart failure,clinical-prognostic value. В сборнике: Актуальные вопросы современной медицины. Сборник научных трудов по итогам международной научно-практической конференции. Федеральный центр науки и образования - ФЦНиО «Эвенсис». 11 марта 2017. С. 7578.,83c.

57. Апухтин А.Ф. Клинико-диагностические параллели тканевого обмена кислорода и функционального состояния миокарда у больных ИБС. В сборнике: Новации в медицине и фармакологии.Сборник научных трудов по итогам международной научно-практической конференции. Федеральный центр науки и образования -ФЦНиО «Эвенсис». Рязань. 25 марта 2017. С. 76-78.,83с.

58. Апухтин А.Ф. Междисциплинарность образовательной среды как фактор гражданского самоопределения медицинских кадров. В сборнике: Новейшие достижения и успехи развития медицины и фармакологии сборник научных трудов по итогам международной научно-практической конференции. Федеральный центр науки и образования-ФЦНиО «Эвенсис». Краснодар. 25 июня 2017. Вып 2.С. 41-43.47с.

59. Апухтин А.Ф. Стандарты оказания медицинской помощи: анализ сложившейся ситуации. МНПК Современные достижения и разработки в области медицины и фармакологии .Хабаровск. Август 2017. Сборнк научных трудов по итогам МНПК: Инновационные технологии 
в медицине и фармакологии вып 2, ФЦНиО Эвенсис. 25 августа 2017. С. 23-26.,33с.

60. Апухтин А.Ф. Современные проблемы стандартов оказания медицинской помощи. Сборник: Современная медицина: Актуальные вопросы и перспективы развития Сборник научных трудов по итогам международной научно-практической конференции. Изд-во ИЦРОН. Уфа 11 сентября 2017. С. 13-16.

61. Апухтин А.Ф. Проблемы технической оснащенности лечебно-профилактических учреждений, доступности медицинской помощи в региональном здравоохранении.Сборник тезисов XII Национального конгресса терапевтов.Москва,22-23 ноября 2017.С.10-11.

62. Апухтин А.Ф. Запатентованные медицинские технологии: вопросы применения. Ж.Патенты и лицензии. Интеллектуальные права. 2017. № 3. С. 73-80.

63. Апухтин А.Ф. Вызовы популяционной стратегии профилактики неинфекционных заболеваний.Актуальные вопросы современной медицины. Екатеринбург 11 марта 2018. Вып V. Сборник научных трудов по итогам МНПК. Изд-во: ИЦРОН,г.Н.Новгород .2018.С.41-43.,90с.

64. Апухтин А.Ф. Особенности профессиональной деятельности фельдшерских бригад СМП в районах Волгоградской области.Сборник тезисов XIII Национального конгресса терапевтов 21-23 ноября 2018.Москва.С.8.

65. Апухтин А.Ф., Инина Л.И. Опыт применения аддитивной терапии диабетической полинейропатии. Сборник тезисов XIII Национального конгресса терапевтов 22-23 ноября 2018.Москва. С.51-52.

66. Апухтин А.Ф. Особенности реализации стратегии профилактики риска сердечно-сосудистых осложнений в России. Сборник научных трудов по итогам МНПК 11 
октября 2018г Волгоград.Вып V: Основные проблемы в современной медицине. Выпуск V. ИЦРОН,.Н.Новгород .2018.C.27-29.,43c.

67. Апухтин А.Ф. Что препятствует принятию популяционной стратегии профилактики сердечно-сосудистых заболеваний и их осложнений в России. Сборник научных трудов по итогам МНПК 25 февраля 2018г г.Н.Новгород ,Вып. III: Перспективы и технологии развития медицины и фармакологии. ФЦНиО ЭВЕНСИС. С. 2224.,51c.

68. Апухтин А.Ф.Медико-социальные аспекты изобретательства на примере региона России .Монография, издательский дом Lap Lambert Academic Publishing, Omni Scriptum Pulishing Group.Latvia.2019.,245c.,опубликовано 25.02.2019. ISBN:978-3-659-91986-2; 


\section{Приложение}

\section{Вопросы анкетирования студентов}

1. Знаете ли Вы о каких-либо отечественных запатентованных разработках в области медицины по профилю кардиологии и эндокринологии:

а) да;б) нет;

2. Используете ли Вы сведения о патентных разработках при подготовке к практическим и семинарским занятия:

а) да; б) нет;

3. Считаете ли Вы целесообразным включение вопросов создания и патентования объектов интеллектуальной собственности в образовательные программы высшего профессионального образования (например, в качестве элективных курсов):

а) да;б) нет;в) затрудняюсь ответить;

4. Считаете ли Вы, что в настоящее время у молодежи есть все возможности для занятия изобретательской деятельностью (в частности, в медицине):

а) безусловно есть; б) частично есть;

в) практически таких возможностей нет;

г) затрудняюсь ответить;

5. Материальное вознаграждение за изобретательство в нашей стране (в частности, в медицине):

a) вполне достаточное; б) не совсем достаточное;

в) совсем не достаточное; г) затрудняюсь ответить;

6. На Ваш взгляд заниматься изобретательством:

а) престижно; б) не очень престижно;

в) совсем не престижно; г) затрудняюсь ответить;

7. Известно ли Вам что результаты интеллектуальной деятельности регистрируются в качестве изобретений, 
полезных моделей, программных продуктов и охраняются патентами:

а) да; б) нет;

8. У Вас самих есть какой-либо интерес к изобретательской деятельности в области медицины:

а) да;б) вряд ли;в) нет; г)затрудняюсь ответить;

9. Вы сами какой-либо изобретательской деятельностью занимаетесь (например, в студенческом научном кружке):

а) да;б) нет;в) затрудняюсь ответить;

10. В студенческом научном кружке Вы:

a) не состоите; б) состоите в одном;

в) состоите в двух или более;

11. Ваш пол:

а) женский; б) мужской;

12.Должны ли изобретения отвечать общественным интересам, принципам гуманности или морали?

а)да; б)нет; в)затрудняюсь ответить;

г)скорее да, чем нет; д)скорее нет, чем да;

13.Знаете ли вы раздел (главу) гражданского кодекса РФ регламентирующий вопросы коммерциализации интеллектуальной собственности?

а)Да; б)нет; в)затрудняюсь ответить;

14.Ограгичивает ли закон срок авторства и имя автора интеллектуальной собственности?

а)Да; б)нет; в)затрудняюсь ответить;

15.Произведения науки, литературы (включая специальную), искусства является объектом авторских прав?

а)да; б)нет; в)затрудняюсь ответить;

г)скорее да, чем нет; 
Длительный порядок принятия решения о выдаче разрешения на применение новой медицинской технологии ( Коваленко Т.Н.,Волокитина А.В. Правовые опросы в здравоохранении.2010).

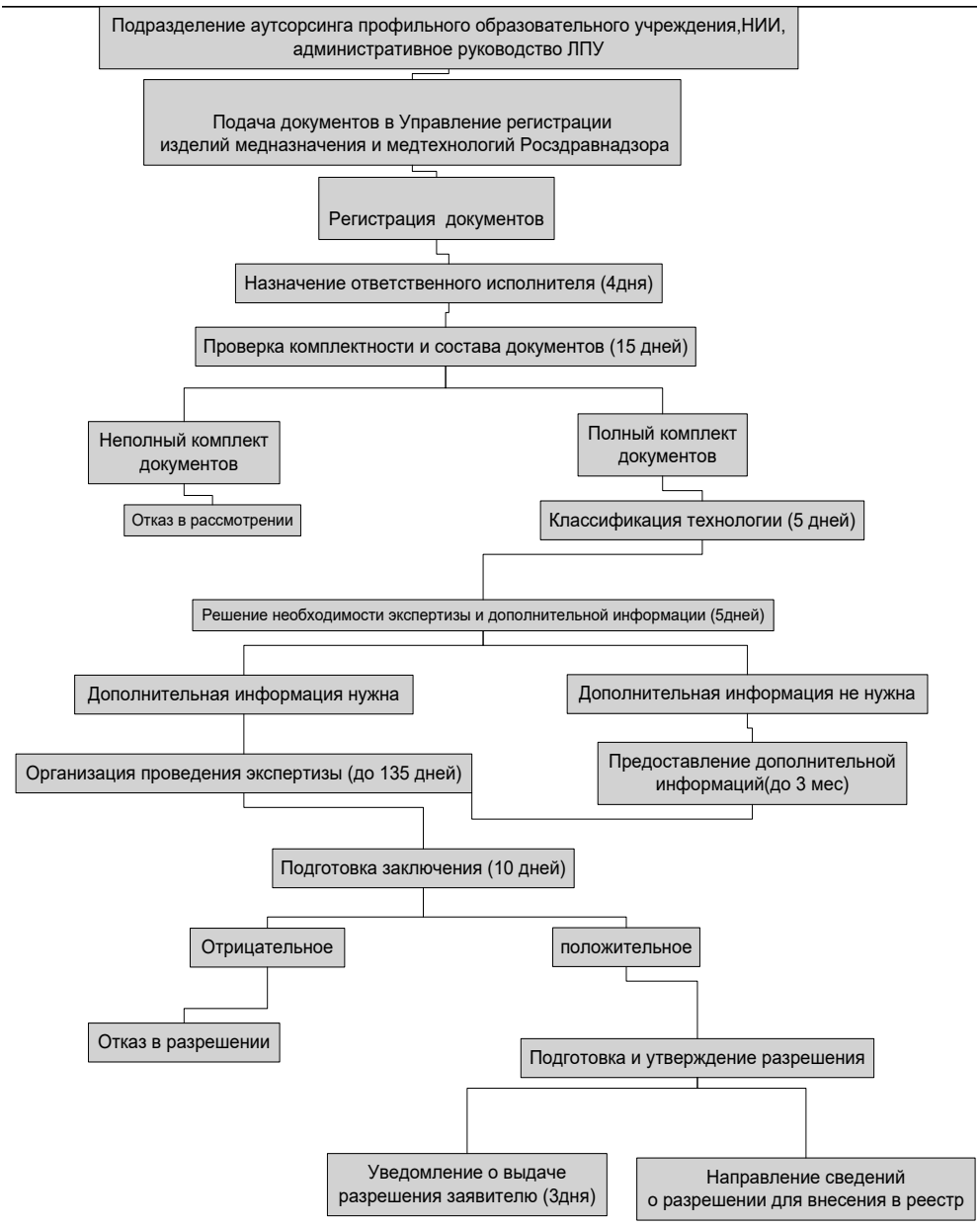

Puc. 2 


\section{РОССИЙСКАЯ АКАДЕМИЯ ЕСТЕСТВОЗНАНИЯ}

(Международная ассоциация ученых, преподавателей и специалистов)

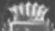

\section{С Е Р И ФИКАТ}

№ Зднт 0166 /0108/

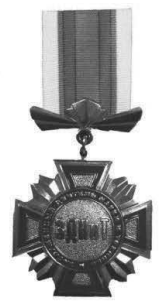

\section{Апухтину Александру Федоровичу}

ПРИСВОЕНО ПОЧЕТНОЕ ЗВАНИЕ

ЗАСЛУЖЕННЫЙ АЕЯТЕЛЬ НАУКИ И ТЕХНИКИ

Президент

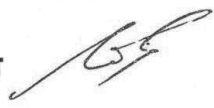
М. Ю.Ледванов

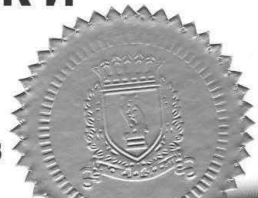

MOCKBA 2016 


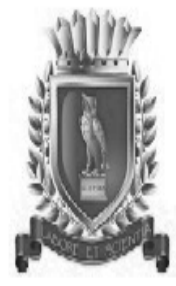

\section{РОССИЙСКАЯ АКАДЕМИЯ ЕСТЕСТВОЗНАНИЯ Международная ассоциапия ученых, преподаватесей и спецнампстов}

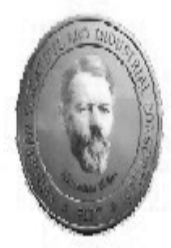

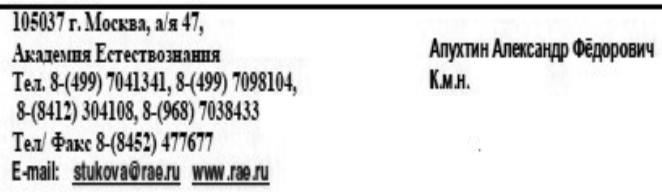

Глубокоуважаемый Александр Фёдорович!

В рамках наднональвой программы «Золотой фонд отетественной наукв» и в соответствни с решеннем комисспи по наградам (Европейского наунно-промьшленного консорцитуау)

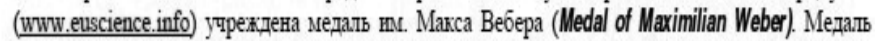
вругается российскнм и зарубежным упеным за признанньй мпровьм сообществом вклад в соцнологическую науду н образованне.

Президиум РАЕ рассмотрел Вашп документы и представил Вас к этой награде, ках ученого, внесшего большой вклад в развитие науки в образования, что подтверждается перечвем Вашшх публикаший в авторнтетных нзданиях.

Положнтельное решенне о награжденин Вас Медалью " $M a x i m i l i a n$ Webe" комнссин по

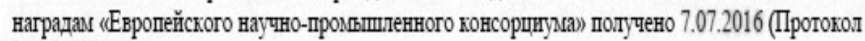
$581 / 7.07 .2016)$.

Торжественное врученне медали им. Махса Вебера состонтся во время проведения Осенней Сессин РАЕ с 9 по 12 октября 2016 г. в г. Сотн (Управтенне делами Президента РФ. Федеральное государственное автономное утрежденве «Оздоровительньй комплекс «ДАГОMЫС", уг. Ленинградская, 7).

Сообшаем, что наградные документы могут быть высланы Вам почтой по ухазанному Bax⿰ адpecy.

с ухазанием топного адреса, номера телефона и фамплин получателя высылается по фахсу

(8452) $477-677$ или по E-mail: stukova_anae.ru

С уваженнем и благодарностью за многоле: яе плодотворное сотрудничество, Ученьй сехретарь Президиуума $\mathrm{PAE}$

к.M.H, профессор PAE Наталия Юрьевна Стукова 


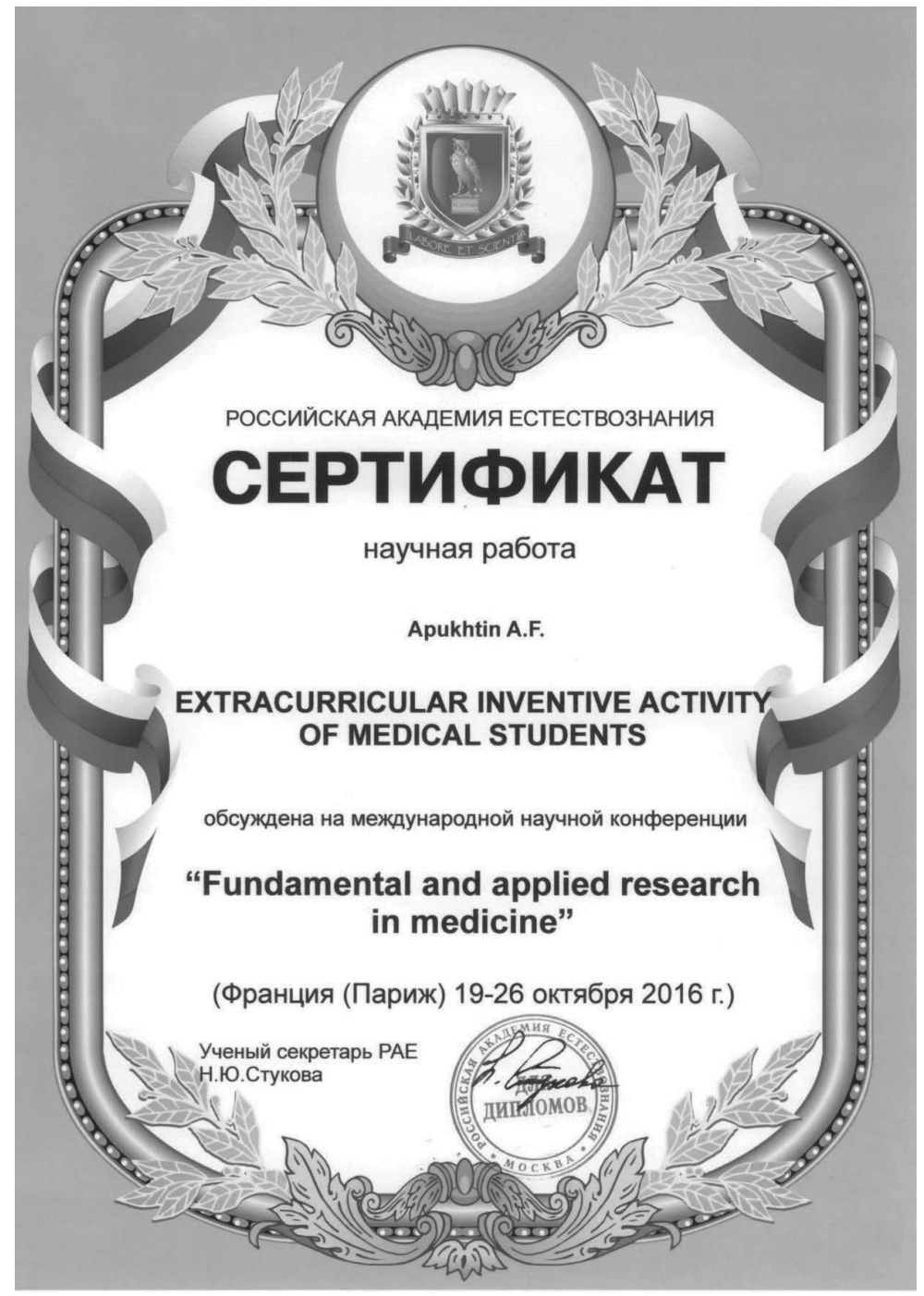




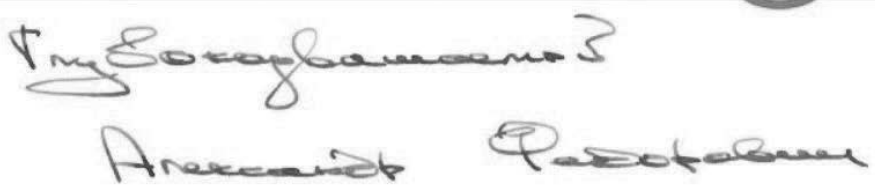

От имени концерна BAYER выражаю Вам свое почтение и признательность за участие в конкурсе проектов на соискание совместного Гранта Российского кардиологического общества и АО «Байер» в области увеличения выявляемости периферического атеросклероза у пациентов с хронической ишемической болезнью сердца, итоги которого были подведены в сентябре этого года.

Активная профессиональная позиция кардиолога, предлагающего алгоритмы, подходы и схемы лечения и курации пациентов с кардиоваскулярными диагнозами, крайне важна. Это вклад не только в улучшение качества жизни пациентов и их семей, но в итоге - спасение человеческих жизней.

Бесспорно, тема периферического атеросклероза у пациентов с хронической ИБС - одна из важных для пациентов, страдающих заболеваниями сердца и сосудов. Однако в области профилактики и лечения данной патологии еще многс областей для пристального внимания, в которых возможно найти и реализовать конкретные идеи и подходы.

Я уверен, что практика научно-практического поиска должна быть продолжена, и позволит большему количеству пациентов жить насыщенной и полной счастливых событий жизнью.

Поздравляю Вас и ваших близких с наступающим Новым 2020 годом. Всем сердцем желаю вам успехов в вашем благом деле.

Искренне ваш,

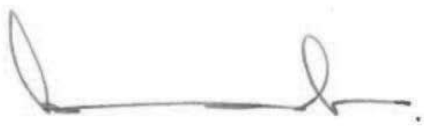

Дмитрий Валерьевич Власов, к.м.н.

Медицинский директор концерна «Байер» в России и странах СНГ 


\section{Содержание}

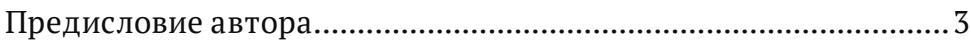

Список принятых сокращений...................................................

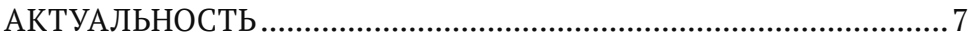

Гипотеза исследования....................................................................12

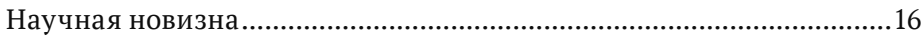

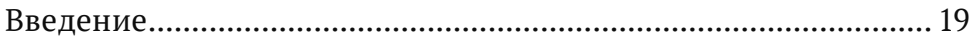

Глава 1. Обзор литературы............................................................ 32

1.1. Предпосылки развития социологических исследований инноваций в здравоохранении России ..............................................32

1.2.Состояние доказательной и страховой медицины, особенности реализации их рекомендаций ............................................................ 50

1.3.Оборот медицинских инноваций и особенности реализации высокотехнологичной медицинской

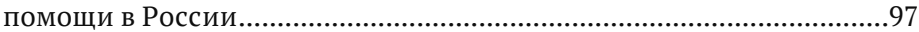

1.4.Проблемы инвестиций

в медицинские технологии России ..................................................127

РАЗДЕЛ ІІ. МАТЕРИАЛЫ И МЕТОДЫ СОБСТВЕННЫХ ИССЛЕДОВАНИЙ......................................... 152

Глава 2.1.Организация исследования ……….....................................152

Глава 2.2. Методы социологического исследования и обработки материала................................................152

Раздел ІІІ. ГЛава 3. РЕЗУЛЬТАТЫ СОБСТВЕННОГО

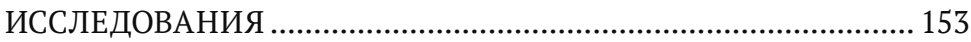

ГЛава3.1. СОЦИОЛОГИЧЕСКИЕ АСПЕКТЫ ИНТЕЛЛЕКТУАЛЬНОЙ СОБСТВЕННОСТИ И ИЗОБРЕТАТЕЛЬСТВА 
ГЛава 3.2. СПОСОБЫ ФОРМИРОВАНИЯ ИНТЕЛЛЕКТУАЛЬНОЙ СОБСТВЕННОСТИ

Глава 3.3. СОЦИАЛЬНО-КУЛЬТУРЫЕ АСПЕКТЫ ИНТЕЛЛЕКТУАЛЬНОЙ СОБСТВЕННОСТИ И ИЗОБРЕТАТЕЛЬСТВА...

ГЛава 3.4. ВКЛАД ИНТЕЛЛЕКТУАЛЬНОЙ

СОБСТВЕННОСТИ В ЗДРАВООХРАНЕНИЕ

(НА ПРИМЕРЕ ЗАРУБЕЖНЫХ СТРАН И РОССИИ)

ГЛава 3.5. КУЛЬТУРА ИНТЕЛЛЕКТУАЛЬНОЙ СОБСТВЕННОСТИ В ВЫСШЕМ МЕДИЦИНСКОМ ПРОФЕССИОНАЛЬНОМ ОБРАЗОВАНИИ

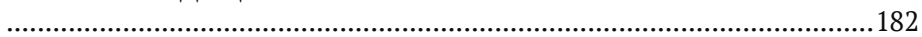

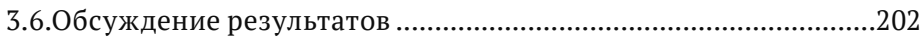

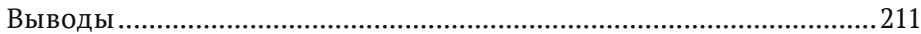

ГЛАВА 4. НОВАЦИОННОЕ ПОВЕДЕНИЕ

ВРАЧЕБНЫХ КАДРОВ ................................................................ 213

4.1. ЛИТЕРАТУРНЫЙ ОБЗОР НОВАЦИОННОГО

ПОВЕДЕНИЯ ВРАЧЕБНЫХ КАДРОВ ………….............................213

4.2.Новационное поведение врачебных кадров (результаты собственного исследования) .........................................................223

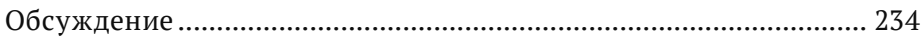

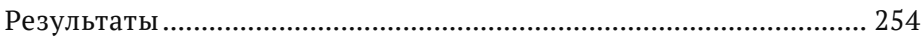

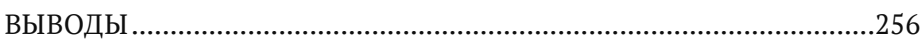

Список публикаций по теме монографии ........................................261

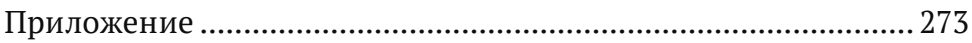

Вопросы анкетирования студентов ................................................273 
